\title{
The Heart of Rural New Zealand
}

Emma Fraser

Submitted in partial fulfilment of the requirements for the Masters of Architecture (Professional) Victoria University of Wellington, School of Architecture 


\section{abstract}

New Zealand rural farming communities are the milieu of the agriculture sector. Despite New Zealand's heavy economic reliance on agriculture, little is known about the architecture for cultivating community in the rural context. Overall, literature on rural communities reviewed for this thesis presented little direct information concerning community and architecture in the rural context. This study is an investigation of how architecture in the New Zealand rural context can cultivate a greater sense of community through the empirical research of existing rural communities. The sociological and architectural theories of community, as a generalised term in the literature, are analysed as determinants for community in the rural context of Northland, New Zealand through empirical research.

The three theories of deprivation, density and development, as well as social interaction opportunities were externally applied to the sample Northland communities of Titoki, Maungatapere and Maungakaramea. Interviews with 18 community members as to their community perception authenticate the variation depicted in the external determinants. Empirical research into the theory of community acceptance analysed the vernacular for rural agricultural and rural community hall architecture. The findings from the empirical research informed the criteria for a case study design in Titoki. The resulting architectural application of these principles from the sociological and architectural theories is a uniquely agricultural rural community building to fulfil the Titoki agricultural community's needs.

This research applies commonly regarded sociological and architectural theories of community to the sample rural context to investigate what and how architecture can enable community. The findings from the sample suggest these theories are determinants for community cultivation in the rural context where architecture is a vehicle for building community. A socially healthy community prospers and is therefore more likely to be economically successful. 


\section{HEART of RURAL $\mathrm{New} \mathrm{Z}$ e a land}

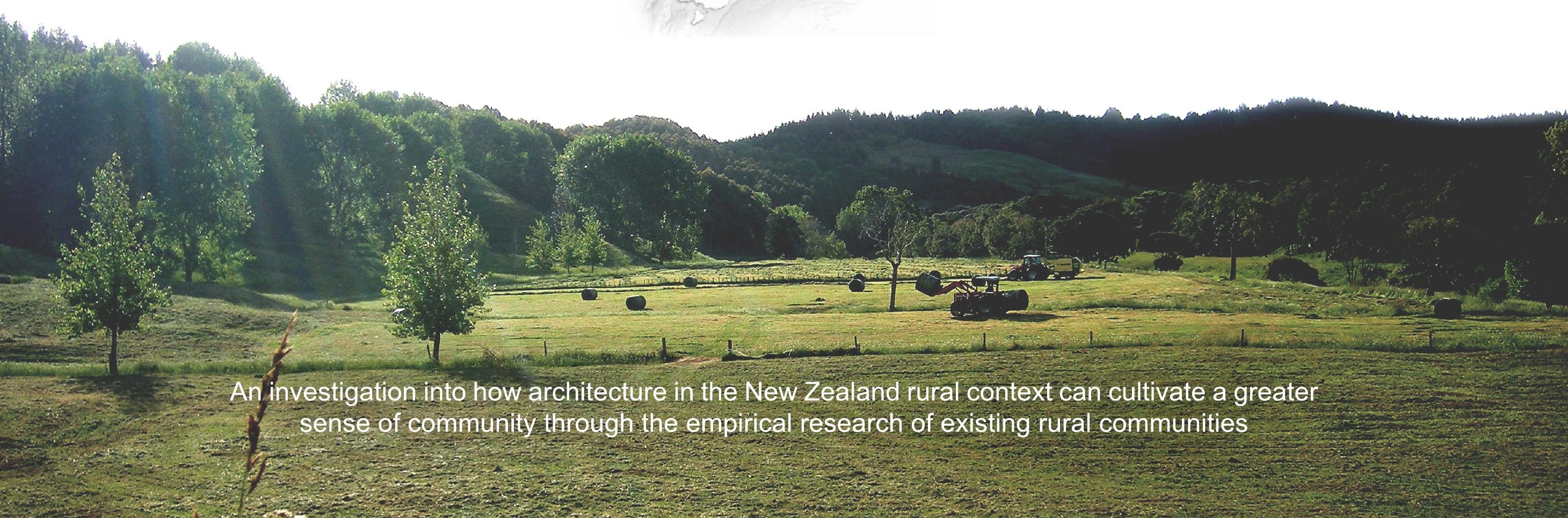




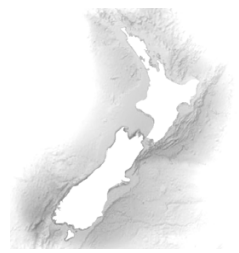




\section{contents}

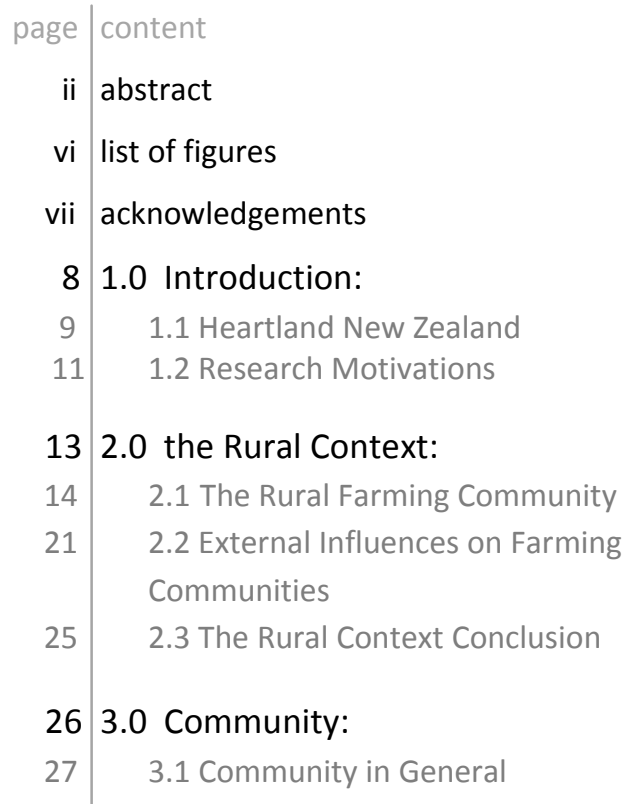

$27 \quad 3.1$ Community in General

$32 \quad 3.2$ Community Design in Practice

$35 \quad 3.3$ Community through Architecture in the Rural Context

36 4.0 Empirical Research:

394.1 Empirical Research: Community Spirit

40 4.1.1 Deprivation

43 4.1.2 Density \& Development

$46 \quad$ 4.1.3 Services \& Employment Opportunities

50 4.2 Empirical Research: the Rural Context

51 4.2.1 Rural Vernacular Architecture

$54 \quad$ 4.2.2 Community Hall Typology

61 5.0 Research Conclusions:
646.0 Design:

65 6.1 Design Brief

$67 \quad 6.2$ Site - Titoki

$70 \quad 6.3$ Design Concepts

82 6.4 Design Reflection

\section{7.0 Conclusion:}

$86 \quad 7.1$ Community Design in the Rural Context

$91 \quad$ 7.2 Further Investigations

92 8.0 Appendix:

93 appendix contents

178 9.0 Reference List: 


\section{list of figures}

\section{page figure}

\section{Empirical Research}

40 4.1.1a Deprivation Index Community Context

41 4.1.1b Titoki Deprivation Index

41 4.1.1c Maungatapere Deprivation Index

41 4.1.1d Maungakaramea Deprivation Index

43 4.1.2a Titoki Density

43 4.1.2b Maungatapere Density

43 4.1.2c Maungakaramea Density

44 4.1.2d Titoki Density with WDC Environment Map

46 4.1.3a Titoki Opportunities

47 4.1.3b Maungatapere Opportunities

47 4.1.3c Maungakaramea Opportunities

48 4.1.3d Number and Distance of Services and Businesses from Titoki and Businesses from Maungatapere

49 4.1.3f Number and Distance of Services and Businesses from Maungakaramea construction secondary structure
Whangarei District community halls surveyed

56 4.2.2b Successful Community Hall Maungakaramea Memorial Hall

56 Sommunity HallKaurihohore Hall

4.2.2d Less Successful Community Hall Portland Hall

57 4.2.2e Less Successful Community Hall Maungatapere Community Hall

\section{Design}

67 6.2a Northland Location Plan

67 6.2b Titoki Community Plan

6.2c Mangakahia River at Titoki Bridge Normal flow level

69 6.2d View across park to site at

intersection of Tokiri (L) and Mangakahia (R) Roads

69 6.2e Mangakahia River at Titoki Bridge Flood flow level

70 6.3a Current Community Situation in Titok

70 6.3b Proposed Community Situation for Titoki with New Development

71 6.3c View from park up to Heartland Centre and Titoki Community Hal

72 6.3d View from the North
72 6.3e Heartland Centre structural concept section

expression - interior Titoki Community Hall

Structural expression of propping the augmented veranda

6.3i Heartland Centre as professionals' offices

75 6.3j Heartland Centre as opened communal space

76 6.3k Heartland Centre timeline showcase

77 6.3I Phase Two: Site Plan

78 6.3m Entrance Canopy - pedestrian user

78 6.3n Entrance Canopy - vehicle user

78 6.3o Entrance Canopy Section

79 6.3p Front (Northeast) Elevation

80 6.3q Adaptable communal space configurations - open floor space options

$806.3 r$ Adaptable communal space configurations - closed floor plan options

81 


\section{acknowledgements}

It is a pleasure to thank all who have supported and made possible the completion of this thesis. I owe my deepest gratitude to the following:

Linda Wong $\mid$ This thesis would not have been possible was it not for Linda's invaluable help as supervisor of the whole process

Participants of the Studied Sample

Communities - Titoki, Maungatapere and

For their insights into their perceptions of rural community life

Maungakaramea

Daniel Hawkins

For his knowledge and help in gathering data

My family For their encouragement, support and help in gathering data 
1.0 Introduction: 
New Zealand's colonized history, albeit relatively short, has a continued association with agricultural farming. New Zealand's economy has a strong focus on resource based exports, particularly agricultural exports such as meat, dairy products, forest products, fruit and vegetables, fish and wool (Easton, 2010; Federated Farmers of New Zealand, 2010; Statistics New Zealand, 2004; The Treasury, 2010). External sources continually threaten this economic dependency let-alone the challenges the industry faces from within its own sector and country. Traditional farming methods can no longer sustain agricultural farming livelihoods - the profit margins vital to the operation of the farm are no longer. The community surrounding agricultural farming is struggling to endure these changes (Save the Farms, 2010; UMR Research Limited, 2008).

'Rural participants in more remote areas felt that

community spirit was diminishing with declining

populations, school closures, the loss of amenities and the rising number of lifestyle blocks.

- (UMR Research Limited, 2008, p. 29)

Explored in this thesis is the plight of rural New Zealand communities as the world, and the world of agriculture changes around them. The aim for this thesis is to investigate how architecture in the New Zealand rural context can cultivate a greater sense of community through the empirical research of existing rural communities.

The research approach used is the application of commonly regarded determinants of community from the sociological and architectural theories on to the rural context. The rural context used for the purposes of this thesis is the three sample communities of Titoki, Maungatapere and Maungakaramea in Northland. The external impartial analysis is tested against the communities' perceptions of theirs' and the other rural communities' social wealth and successfulness. The alignment of the external and internal analysis informs the criteria for the architectural intervention to promote community. The second thread of criteria is of community acceptance through the analysis of vernacular architecture to provide aesthetic criteria for the architectural manifestation of community. This criterion is applied to the architectural translation of community cultivation in a case study building for Titoki.

The research approach is structured into several chapters following the research motivations. In chapter 2.0 the Rural Context, literature is reviewed to understand the context in which the architecture is to help encourage community. Chapter 3.0 
Community is a review of the sociological and architectural theories of community and community building. Due to the lack of direct information in the literature on rural communities and their architecture, 4.0 Empirical Research is used to verify the determinants of "successful communities" claimed in the literature with relation to the rural context in New Zealand. Chapter 5.0

Research Conclusions is a summation of the literary and empirical research. From here, 6.0 Design focuses on a case study design in the rural setting of Titoki. Introduced in the design chapter is the brief - devised based on the research conclusions, the site and the design concepts. The design chapter concludes with a reflection on the success and usefulness of the brief as basis for design. The final chapter, 7.0 Conclusions, summarises the results of the research and its application to the architectural process of cultivating community. The thesis culminates by outlining possible future investigations in to the encouragement of community in the rural context.

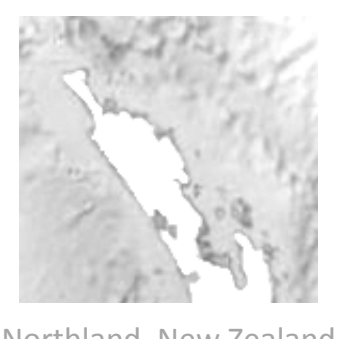


Although the rural context of New Zealand is one of the key drivers of the economy, little effort is made to see that the communities of these rural areas are prospering. This section states the merits of research in the field of architecture as an enabler for community in the rural context.

Long term productivity, such as the growth rate of $1.8 \%$ per annum of the agricultural sector ${ }^{1}$ from 1998-2008 (Federated Farmers of New Zealand, 2010), is a determining factor in international competitiveness and economic growth. In the year that ended March 2008, the New Zealand agricultural sector made a direct contribution of $5 \%$ to the gross domestic products (GDP) excluding downstream processing. Agriculture is estimated to have contributed over $15 \%$ of the total GDP when downstream processing is included (Federated Farmers of New Zealand, 2010).

Agribusiness is big business, and it is taking over the traditional farming typologies of New Zealand's farming history. Across both the dry stock and dairy industries there has been a shift away from the traditional farm sizes towards larger farming units. There is also an increase in smaller lifestyle block numbers. The net result is

\footnotetext{
${ }^{1}$ The growth rate of the agricultural sector is double that of the economy as a whole.
}

fewer total farm numbers concentrating agricultural production on smaller number of larger farms (Livestock Improvement Corporation, 2008; Mulet-Marquis \& Fairweather, 2008; Windels, 2000). Based on production per hectare figures from the Ministry of Agriculture and Fisheries (MAF) (2002) and Livestock Improvement Corporation (2008), it can be concluded that farmers are increasing their average farming unit to increase productivity of the unit. MAF (2002) have found that although small sized farms are generally more efficient with their output per hectare, they do not have the size to make the cash surplus for many operators to remain financially viable.

The current framework that supports the agricultural community is no longer coping as the scale of agriculture changes and develops into agribusiness. The sphere's of agriculture and the rural community have slowly but steadily drifted apart (Joseph, 1999). The traditional techniques have morphed into business-oriented and production-driven procedures. Future communities need to reflect the cultural and technological shifts and not 'return to the (supposedly) cosy localism of the past', (Barton, Grant, \& Guise, 2003, p. 3). The architecture and the built environment alone do not create community but can create conditions where a sense of belongingness and community is likely to develop. 
Behind the plants and animals - that ultimately produce the goods there is a horde of people to see that the end goods are of quality and quantity. Therefore, how can we expect the produce to receive all the provisions and care, with all the requirements met, without supporting those who do the nurturing? They are expected to cultivate a major export, which the country's economy is built on; but what sustains them?

'Rural communities are the backbone of our economy...'

- Rt. Hon. John Key in his Key Notes website (2010). 
2.0 the Rural Context: 
In order to design architecture to facilitate community cultivation, the context of that community - the rural farming community needs to be understood. This chapter seeks to identify the rural farming community. Firstly in this section, a brief explanation of identity is followed by a definition of the rural farming community focused on the three sample communities in Northland. The remainder of this section investigates the factors affecting the rural context. This is explored through the history of farming including agribusiness, market influences, employment in farming, and the farming community demographic.

An important aspect of identity is a sense of belonging. Individual identity is strongly dependent on the groups people belong to.

Smith-Lovin (2007) provides two sides to the argument about the definition of identity. One is from Stryker whose definition is identity as role-identities and their internalized meaning to the individual. The other is MacKinnon and Heise's - and Smith-Lovin's own - definition of identity as the labelling of people into categories based on cultural theories and the logical implications of such labels.

For the purpose of this thesis, the rural community identity is based on the demographic of its population, aligning with MacKinnon and Heise's theory. Research into the demographic of the rural communities has provided labels and categories for members of the community. The amalgamation of the individual identity labels gives the community its identity.

'What we do depends much more on where we are and who we are with than who we are.'

- Roger Barker and colleagues in (Smith-Lovin, 2007, p. 106)

\section{Rural Community Definition}

To clarify this thesis's definition of rural community:

Rural area with low urban influence:

'This category identifies rural areas with a strong rural focus. The majority of the population in these areas work in a rural area. Due to the impact of the weighting system, it is unlikely meshblocks $\left[{ }^{2}\right]$ in this category will have many people employed in a main urban area, although a number may work in a minor urban area.'

- As characterised by Statistics New Zealand (2005a) in Defining Urban and Rural New Zealand.

${ }^{2}$ Meshblocks are a geographical unit found to contain approximately 87 people according to the 2006 census. 
Statistics New Zealand (2005a) have refined their definition of rural communities from 'in or of the countryside where the population is less than 1000 residents', to one which depicts the characteristics of the area more accurately. The classification system is based on the dependence of the community on outside influences such as distance of employment from their usual residence. Two categories are formed with associated subcategories as follows:

- Urban Areas:
- Main urban areas
○ Satellite urban communities
○ Independent urban communities

- Rural Areas:
- Rural areas with high urban influence
- Rural areas with moderate urban influence
- Rural areas with low urban influence
- Highly rural/remote areas

The differences between a rural community dependant on rural livelihoods and a rural living/urban working commuter community are vast. The latter community has access to readily available urban services providing a significant focus for the commuter community. Rural communities tend to be more isolated from the resources of urban area services. Health is a crucial resource seen by Statistics New Zealand (2005a) to be deficient in many rural areas.

Rural areas with low urban influence form a significant part of New Zealand's economy as employment is predominantly in the agricultural sector. Statistics New Zealand (2005b) population projections for 2001-2031 suggest a slight population growth for low urban influence areas compared to that of rural areas closer to urban centres. The sample communities in the empirical research are all within the 'rural area with low urban influence' category.

\section{History of Farming:}

New Zealand still has a large amount of capital invested in the farming industry due to our continuing involvement with the primary sector and the relationship of farming as a building block in history (Ville, 2000). Originally, this large investment in the agricultural sector was considered quite risky for the poorly developed economy ${ }^{3}$, however it has seen the development of secondary and tertiary production industries ${ }^{4}$ that are now flourishing. At the turn of the twentieth century, around 40 per cent

\footnotetext{
${ }^{3}$ The economy was dependant on one market and relied heavily on privileged links to 'Home' (Ville, 2000)

4 Subsequent industries from the farming industry are processing, infrastructure up grading of roads for transportation, dairy and meat works, engineering etc.
} 
of New Zealand's workforce were employed in the primary industry (Callister \& Didham, 2010; Ville, 2000). Farm employment has steadily reduced due to advances in technology and more mechanised farming methods. By 2006, reports were of only seven per cent employment in the primary industries (Callister \& Didham, 2010). This has seen a change in the rural community demographic. There is now a concentration of pressure placed on smaller number of providers to continue the economic driver.

\section{Agribusiness}

Rhodes, Willis, Smith and McCann (2003) recognize that farming has developed from a lifestyle into business. This development is changing the context in which the farming community live. The change in the economic and political environment is effecting the community environment. With pressure now placed on farming margins, larger farm units are required to gain benefit from the economy of scales ${ }^{5}$. With much of the price of the end product

\footnotetext{
${ }^{5}$ MAF (2002) states the standard size for settlement farms post World War II was 80 ha for sheep and beef farms, and 40 ha for dairy units. Sheep and beef farms have witnessed a shift with higher numbers of farms in the over 800 ha category and markedly lower farm numbers in the 40-399ha categories (traditionally the most common dry-stock farm size) since 1993. Since 1972, the average dairy farm size was 70ha running 117 cows. This has grown to $126 \mathrm{ha}$ running 351 cows (Livestock Improvement Corporation, 2008). MAF (2002) has suggested a plateau of production at
}

added to by the post-farm processing, lower returns are being seen by the farmer (Yerex, 1992). According to MAF (2002), and supported by the more recent findings based on the 2007-08 season statistics, it can be concluded that increases in productivity are only likely by increasing the average size of the farm if a total increase in farm production cannot be achieved by increasing production per hectare.

The viability of the typical family farm of the 1950's is threatened. Small-scale farms tend to have a higher economic farm surplus per hectare but this is offset by the total surplus not being large enough to pay principal repayments, plant replacements, drawings and taxation costs to the farm (Ministry of Agriculture and Fisheries, 2002). Smaller farms also tend to be overvalued for their income earning potential thus, debt repayments are higher than possible to make off the farm's income alone. According to Ville (2000), they have been placed under pressure from increased indebtedness and the lure of consolidation into larger more profitable agribusinesses.

As the current trend in dairy farming is to concentrate production in a smaller number of larger farms, pressure is placed on milking and milk collection systems of the existing infrastructure. The obvious economic downfall is a decrease in milk quality through negligence.

2.8 cows per hectare with production increases at only $1.5 \%$ over the last ten years (Livestock Improvement Corporation, 2008). 
It is feared that staff take less care than owner-operators take and economic pressure will cause farmers to only comply with industry standards or even take risks to return a profit. In 2010, debate has arisen surrounding the ownership of New Zealand's prime farming land and overseas investment (Bennett, 2010; Dickison, 2010). Profits line the investor's pocket, which may not translate to development of the farm or into the immediate surrounding economy. 'Can we afford to sit back and let [foreign ownership] happen to our large farms and the communities they support?' is the question Save the Farms Incorporated (2010) ask.

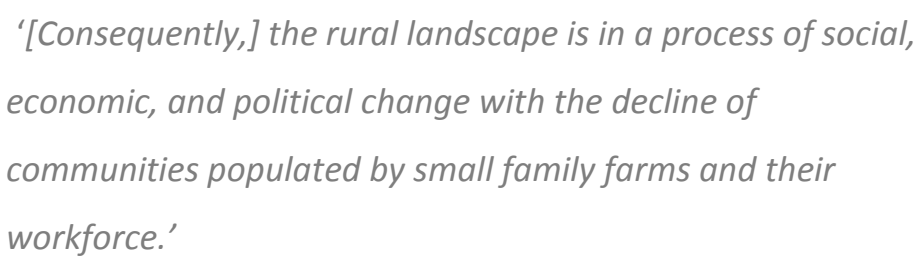

Farmers are becoming tied to a larger body, disassociating themselves with the local communities. The need for intermediary services is met by competitive spot exchanges or by internalized sources for services rather than loyalty and long-term relationships. Traditionally these were forged within the community, both the immediate and larger external community. Therefore the rural farming community is becoming the rural agribusiness community - a less traditional community of fewer established families and a higher percentage of transient workers.

\section{Market Influence}

The natural laws of economics play a big role in the farming industry and consequently are reflected in the community. The "fast food" market of maximum production at the lowest cost through intensive farming sees bigger gains than that of the organic market (Yerex, 1992). The demand for organics is increasing yet is only just becoming an economically viable option with the environmental sustainability and niche production lure. Organics coupled with the emergence of the rural lifestyle block is seen by Joseph (1999) to blur the boundaries between agriculture and community. Farming organically requires more communication, dependency on labour and collective knowledge to prosper thus rekindling community (Joseph, 1999; Rahman \& Yamao, 2007). Organic farming brings variety into the community as new people and farm types enter the area, broadening the community's economic and agricultural base.

Yerex (1992) claims that in America, many of the decisions surrounding land use are made in the interests of agribusiness overshadowing the human needs of the community. Market forces are not the sole determinant of farming policy in New Zealand, as this 
would have lead to non-environmentally friendly practices being widespread within the industry.

\section{Employment in Farming}

Statistics New Zealand (2005b) reports the most significant occupation for rural residents is in the agriculture and fisheries industries. Employment in the rural service industry, in particular health and community services, is lower than the national average. Rural communities have a higher percentage of employers, selfemployed and unpaid family workers, as most farms are owneroperated or managed.

With the changes in farming practices, families have had to diversify their income, up-scale or reduce farm in-puts to survive. A decline in in-puts such as labour and services reduces the demand placed on the rural community for workers. The reduction of labour required from the community coupled with the increase in job demand on the community by the farmers is exacerbating the problem.

'Employment is clearly a key site at which the rural

community is being (re)defined,'

- (Joseph, 1999, p.15)
Rhodes et al (2003) support this and mention that the success of farming is also no longer based on hard physical labour but changing towards office and managerial skills.

The wider the economic base that is created with job market opportunities, the stronger the community will be (Kelland, 1993). Diversification of job opportunities allows the community to stay local. As communities are increasingly gaining the technology to travel further and faster, and the need is there for them to do so in certain areas of services, they are conveniently acquiring a range of services from outside of their community. This is threatening the viability of the remaining local businesses. The lack of support forces them to close and further compounds the problems of employment opportunities within the community. Therefore keeping the community local for their services and employment is an economic advantage. The agricultural sector is what grounds the residents in the community, other opportunities for services and employment will help to keep them there. 


\section{Farming Community Demographic}

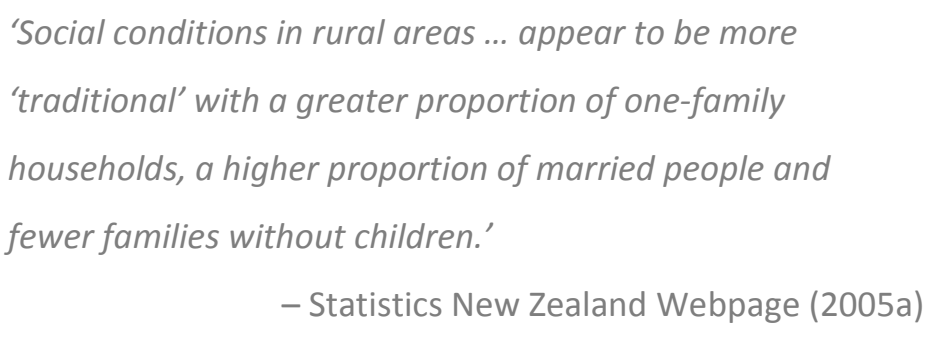

Northland - the location of the three sample communities for the empirical research - is the most rural region in New Zealand.

Statistics New Zealand's regional profile of Northland (1999) placed only 52 per cent of the Northland population to live in urban areas. Rural communities have a distinctive population with a diverse range of people groups. Rural community population groups include:

- the farmers, ranging from the traditional to the most innovative to the corporate farmers

- the group of service professionals such as health, social, educational, recreational, entertainment, commercial and retail providers

- those who are part of the open society where technology has allowed them to live in the rural area while still maintaining an income from a city
- the group who rely on their craft and skills or a partner to provide the income

This community thus extends beyond the physical boundaries of the defining region, in particular with commercial and retail providers for whom rural residents are now more likely to travel to gain services.

The aging population is proving to have its greatest concentration in the rural areas (Statistics New Zealand, 2006). As the already aged population retires, the rural areas are seeing immigration of retirees for its amenities. These areas do not have the resources or services available to meet the needs of the retirees as they become the elderly. This is occurring simultaneously as the younger generation emigrate for opportunities in the city leaving the rural communities with a disproportionately aged society (Joseph, 1999; Statistics New Zealand, 2004; Ward \& Brown, 2009). Statistics New Zealand data (2005b) shows that rural areas with low urban influence have a higher proportion of young children and low numbers of young adults and elderly.

Ethnically, rural areas with low urban influence predominantly

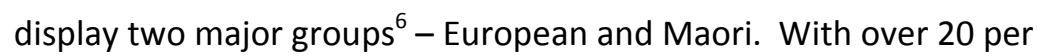

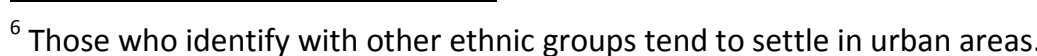


cent of their population specifying Maori ethnicity and a high proportion of Maori speakers, the Maori culture is able to be continued through what is a largely an oral culture (Statistics New Zealand, 2005b). Maori culture tends to be quite visible through land claims and assertions in identity coupled with their high numbers. The Resource Management Act (RMA) also has an effect as it gives credibility by specifically recognizing Maori values adding to their visibility in policy-making. The elderly and Maori tend to be in direct competition for the attention of the policy-makers with the needs of the elderly not as vocalized (Joseph, 1999). 
This section explores the factors influencing the rural context beyond agriculture. The topics covered are technology, the public sector and the governmental authority on the rural context. These areas all have a part to play in shaping the rural community to a lesser extent than agriculture.

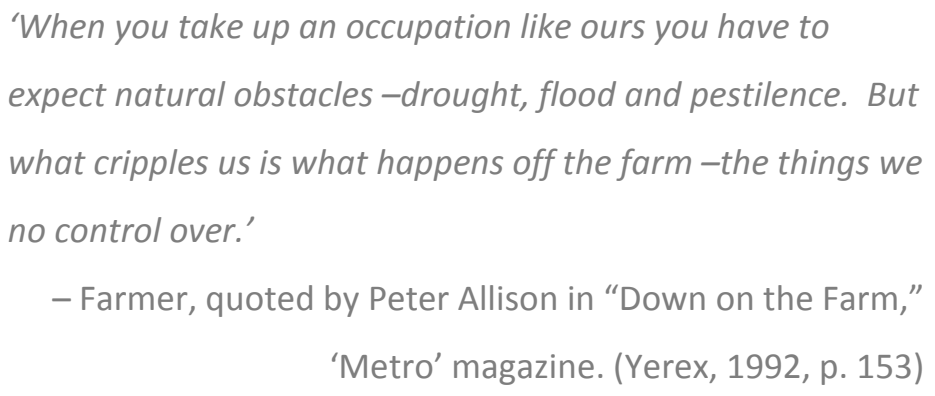

\section{Technology}

Advances in technology have lead to an open society (Joseph, 1999; Ward \& Brown, 2009). It is possible to remotely perform tasks which would have required more time and labour had it been performed ten years ago. Technology has replaced the need for labour and in some cases management on farms decreasing the number of farmers. This has dislocated of the social, economic and political spheres of rural life. The shift has changed the way in which communities reproduce themselves. Now, more than ever, there is a demand for technological competency and less human contact devastating the traditional rural farming community dynamic.

\section{Rural Public Services}

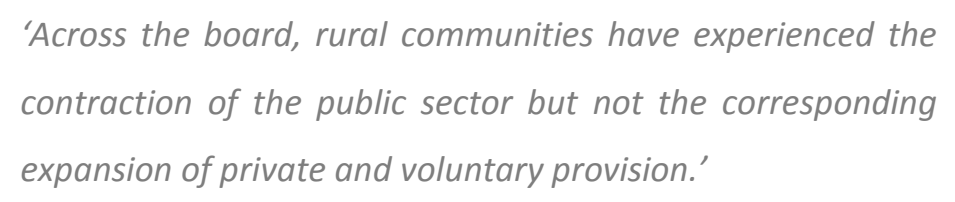

The smallest communities typically lose their public services first and it is not plausible for the private sector to replace them. This withdrawal of investment from the smaller communities has seen the professionals in those areas losing employment opportunities. Affected communities' in-turn lose their interdependence, vital to their confidence as a community. Schools are the last bastion of the public sector investment in many rural communities (Rose, 1994). The school's social role as a nucleus for community activity is important, in particular for rural communities (MAF, 1994). Unity for the community is created by the school with those who attend from the preschoolers to the community-educated adults, parents and teachers providing opportunity for social interaction. The grounds act as a neutral area that can be shared, the inclusion of other facilities such as swimming pools, halls, career courses and 
libraries provide a point of social interaction. Particular importance is placed on sport and recreational activities that may be hosted on the school grounds as a way to bring the individuals within the community together. These occasions bond the community and give them a common and shared experience. For newcomers into an area, the local school can pose as a way of meeting people especially when children are involved. A concentration of community activities is risky, as some feel unwelcome at the school thus excluding them from all community activities associated.

\section{Government Policies}

'Smallness in population and remoteness from larger urban centres tend to go together. They pose a considerable challenge for government at all levels in meeting the local needs of these small dispersed and relatively isolated populations.'

- (Hogg \& Carrington, 2006, p. 64)

Government policies define the environment in which all New

Zealand lives. Nationally, government policies affect the farming community collectively while at the local level, regional and district council's enforcement of legislation affect farming community life specific to their area. New Zealand's Local Government Act 2002

(LCA) defines the purpose of the local government to 'promote the social, economic, environmental, and cultural well-being of

communities, in the present and in the future,' (Department of

Internal Affairs, 2009). Field (2008) theorises that the government's

best role in community development is to serve as an enabler, and then to stand back. From a national perspective, the advent of the Resource Management Act 1991 (RMA), the Building Act 2004, the newly introduced emissions trading scheme (ETS), and (subsequent removal of) subsidies, all affect the farming communities' environment.

\section{Resource Management Act 1991}

The introduction of the RMA into legislation brought about protecting the natural environment and resources for future generations by managing the effects of use. While many farmers have a strong stewardship ethic, this type of regulation restricts them by imposing the need for resource consents on common farming practices (Ministry of Agriculture and Fisheries, 1993). This control is one prevention method to stop the exploitation of New Zealand's natural resources.

\section{Building Act 2004}

The built environment of New Zealand is subject to the Building Act 2004. The current review of this legislation has recommendations which will make it easier to get building consent for low risk works 
such as large rural sheds (Department of Building and Housing,

2010). These amendments are not expected before 2012 but are

likely to encourage traditional farmers to have works consented.

Agribusiness farmers are already more inclined to have

professionals undertake the work opposed to doing it themselves.

Beyond this, the rural context's built environment is treated

indifferently.

\section{Emissions Trading Scheme}

The rural context's economic environment since July 2010 has been effected by the ETS. It was estimated that the cost of the ETS implementation on to the energy and industrial sectors will impact on the average dairy farm $\$ 3335$ per year and the average beef and sheep farm by $\$ 1183$ per year (Ministry for the Environment, 2010). By 2015 , the agricultural sector will be directly affected, only if other trading partners make progress.

\section{Subsidies}

Farming subsidies were viewed by many to discourage innovation, diversification and productivity (Rhodes, et al., 2003). As the international markets declined and inflation ${ }^{7}$ escalated during the

\footnotetext{
${ }^{7}$ A period of inflation began November 1967 when the Labour government of the time tried to bring in a subsidy for the consumer from the beef exporters margin, failing this, they devalued the New Zealand dollar making it less favourable for exporters deepening the policy of economic insulation for New Zealand (Chamberlin, 1996).
}

1960's, New Zealand farmers became subsidized. This encouraged farmers to borrow unrealistic sums of money for development and subsequently brought about a debt crisis. The political changes in the mid 80 's saw a reform of government subsidies for the agricultural sector. In 2010, farmers rely on the international markets and its vagaries to determine income. Much of the literature produced since 1995 argue the removal of subsidies proved to be a catalyst for productivity gains in agriculture (Rhodes, et al., 2003).

It is claimed by Yerex (1992) that the farming sector is losing its political power as urbanisation increases. He argues that government policies concentrate on the urban environment, of which many are often not applicable in rural areas. These policies are sometimes even detrimental. Kelland (1993), claims it is the local authorities strategies for community projects that is important in achieving successful rural economic development.

\section{Local Government}

Whangarei District Council (WDC) (2010b), who oversee the sample rural communities in the empirical research chapter, do recognize and see it a necessity to retain the varied nature of rural areas. WDC identify the need to enhance the social networks that maintain rural communities. They hope to address a range of rural needs 
from the elderly remaining in their familiar communities, growing diversity for use of community halls, enabling city based

organizations services, to encouraging safety, security and selfsufficiency. One of their key considerations in the district plan pertaining to the rural environment is the adverse effects of sporadic development on amenity values.

Currently in the WDC District Plan (2010b), there are no provisions for rural residential development even though it is recognized as needed to prevent adverse effects on the inherent rural characteristics. The proposed Plan Change 93 (2010a) - Urban Transition Environment (UTE) - is an intermediate environment zone typology for urban fringe subdivision development. Although not proposed for rural communities, UTE is development towards addressing the rural and urban interface in district plans. The proposed UTE deals with the issue of sprawling lifestyle block development on the fringe of the city and its adverse effects on the productive capacity of farms. Plan Change 93: UTE (Whangarei District Council, 2010a) proposes:

- A density of 2 sites per hectare

- Maximization of open space outlooks

- Clustering of building sites to within $50 \mathrm{~m}$ from any existing or proposed building site
- Protection of 50 per cent of the land within proposed subdivisions from residential buildings or further subdivision by way of legal covenant

- Shared wastewater and water supply management

- Building set back of $50 \mathrm{~m}$ from state highways and formed legal roads

In the UTE, there is no mention of a community plan or neighbour guidelines. There is no specific development strategy like the UTE between the living $1^{8}$ and countryside ${ }^{9}$ zones for rural communities in the WDC environment zoning plans.

\footnotetext{
${ }^{8}$ Living 1 is classified as a net area associated with each residential unit of at least $500 \mathrm{~m}^{2}$ with a height restriction of $8 \mathrm{~m}$ and the site coverage does not exceed 35 per cent of net site area in the Whangarei District Plan (2010b).

${ }^{9}$ Countryside is classified as a net area of 20 ha associated with each residential unit not exceeding $10 \mathrm{~m}$ in height and site coverage does not exceed $500 \mathrm{~m}^{2}$ or 5 per cent of net site area in the Whangarei District Plan (2010b).
} 


\subsection{The Rural Context Conclusion}

One of the key findings from the literature reviewed of the rural context, and in particular, rural areas with low urban influence (this thesis's definition of rural community), is the heavy reliance of this context on the agricultural industry. Agriculture is a fundamental aspect in forming the rural context's identity.

\section{The Rural Farming Community}

The continual state of change occurring in the agricultural sector is influencing the communities within the rural context. As the traditional farming model is changing towards agribusiness, farming practices are developing to reflect this. Employment in the rural context has changed; those displaced are now looking to other employment options that may have been disbanded when agribusiness removed the support or were never there. The demographic of the rural farming community only has slight variation from the national figures, but what is unique about the rural farming community is their dependence on the agricultural sector

\section{External Influences on Farming Communities}

While technology and the public services available both affect the rural community, the government policies are the second most influential on the rural context. At a national level, the policies have some effect on agriculture but the local government policies directly affect community life. They are the enablers of community through planning directives. The rural context is often over shadowed by the urban context in this area. The WDC currently have no policies emphasising rural community building or neighbourhood guidelines even though rural residential is considered important in preventing adverse effects on rural amenities.

This chapter has evaluated who the rural context is so that they can be designed for. The next chapter looks at the ingredients for creating community now that the rural context has been clarified. 
3.0 Community: 
The causes and effects of community need understanding to translate community into architecture. In this chapter, sociological and architectural theories of community are examined both generally and in the rural context from the where the literature has allowed it. A community is a cohesive unit that interrelates with the wider district and is socially interactive and economically interdependent. Falk and Kilpatrick (2000) refer to community-ofcommon-purpose which encompasses communities of place, organization/corporate, professional, virtual or other interest group. This section is an overview of sociological theories surrounding social capital, technologies' influence and community dynamics including deprivation.

\section{Social Capital}

'Social capital is the sum of resources, actual or virtual, that accrue to an individual or a group by virtue of possessing a durable network of more or less institutionalized relationships of mutual acquaintance and recognition.

$$
\text { - (Field, 2008, p. 17) }
$$

Social Capital is a sociological concept relating to the worth of the community based on social networks and connections within and between communities. It is difficult to measure the value of a community's social capital, as it is not a tradable commodity (Field, 2008). It derives its strength from the context in which the social network is located. In order to keep a high value of social capital, individuals must work at the relationships and networks. Like commodities, Falk and Kilpatrick (2000) state that community social capital can devalue. They propose the development of social capital as dependent on both the quality and quantity of social interactions. Opportunities for quality interaction need to be available to the communities for building social capital like those in Ray Oldenburg's "third places" - gathering places in the community outside of the home and work places (Bohl, 2002).

The collapse of social capital is something that Putnam (2001) has attributed to people's steady disengagement from public life. Many people are choosing to disconnect themselves from their local community in favour of the world - at a distance - through technology. Because of the decreasing participation in public life, the health of the community suffers.

Social capital is referred to by Hogg and Carrington (2006) to substitute the lack of professional bureaucratic services and infrastructures in the rural context. The physical isolation of rural communities prompts voluntary community building - rural 
communities tend to run local events and maintain their communal spaces through volunteer committees. Actual construction or funding may require council support but beyond this, the expectation is back on the community (Whangarei District Council, 2007).

Mutual support, trust and interdependency are crucial to the survival of such isolated communities (Hogg \& Carrington, 2006).

Trust is the foundation to meaningful communication, this produces social order and understanding between participants. This leads to effective governance, productive economies, healthy populations and socially cohesive communities as they work together. Advances in technology, particularly communication technology, have lead to this isolation being all but removed from most communities today (Barton, et al., 2003; Joseph, 1999; Statistics New Zealand, 2009).

'We are faced with having to learn again about

interdependency and the need for rootedness after severa centuries of having systematically - and proudly -

dismantled our roots, ties, and traditions. We had grown so tall we thought we could afford to cut the roots that held us down, only to discover that the tallest trees need the most elaborate roots of all.'

- Paul L. Wachel in (Shaffer \& Anundsen, 2005, p. 6)
Bonding and bridging are elements of social capital heavily mentioned throughout Field's (2008) and Halpern's (2007) work. Bonding is the superglue that reinforces the exclusive specific identities, develops strong loyalty, and homogeneity. Bonding is particularly high between immediate family, close friends and neighbours. An excess of bonding within a community can contribute to insularity and intolerance of others (Hogg \& Carrington, 2006). This concentration of close bonds within a community removes privacy. Likewise, when businesses amalgamate (banks, post offices, pharmacies etc.) the stepped privacy barrier is removed.

Bridging in social capital refers to external asset links, bringing together people from diverse social divisions - the relationships with workmates and loose friendships (Field, 2008). These extended relationships generate broader identities and create reciprocity amongst those within the relationships. These links enable members of a community to access a wider range of resources than those available locally. Economic performance is better in wellconnected societies (Field, 2008). 


\section{Maori Social Capita}

For Maori there is no separation of family and community. The concept of whanau ${ }^{10}$ transcends the European definition between family and community. The whanau is the basis of all things to Maori - it is the family relationships that strengthen all other relationships (Spellerberg, 2001). Maori values/norms come from the traditional and fundamental values that are rooted in whanau. Sense of place in Maori society is the knowledge of who you are, how you relate to others and where you belong. Therefore, this sense of "place" extends beyond geographical boundaries to wherever the members of the iwi ${ }^{11}$ are. For Maori, there is no distinction between cultural capital ${ }^{12}$ and social capital (Spellerberg, 2001). Maori social capital is an expression of the culture in practice. It is in this way that Maori society has a strong sense of who they are, where they belong and what their identity is.

\section{Technology and Community}

As previously mentioned, advances in technology have lead to an open society. This has lead to conservation biologist David Ehernfeld (2009) to use the term pseudocommunities for

\footnotetext{
${ }^{10}$ Kin group

${ }^{11}$ Extended kinship group, tribe

${ }^{12}$ Cultural capital consists of values, history, tradition and behaviours that link groups together (Spellerberg, 2001)
}

electronically linked communities that replace real ones. He states that every advance in technology is bringing about social disintegration. The face-to-face nature of human contact is substituted with electronic synthesized interaction (Ehrenfeld, 2009; Watt, Lea, \& Spears, 2002). On the other side, the "technological visionaries" predict that the widespread adoption of technology will lead to the improvement in quality of community-of-place (Kolko, 2003). A balance between both - where communities have access to the choices outside their community yet have a great enough loyalty to their community's societal ties and expectations - needs to be found.

Mark A. Jones comments on his vision of community websites serving as 'a forum to facilitate community interaction [and will] become a catalyst for increasing civic engagement' (2003, p. 356). A similar conclusion is made by Watt et al, (2002) where interaction over the internet is no less social than face-to-face communication and may lead people to behave in a more socially regulated, normative way.

\section{Community Dynamics:}

High social capital typically serves the immediate group interests well but can be at the expense of the wider community. The group landscape created has socio-spatial boundaries of what and who 
belongs, and those that do not - the type of social development of perceived superiority and prejudice seen in gangs and the mafia (Hogg \& Carrington, 2006)

'Unwanted social change is change that threatens a notion

of the community that is invariably idealized in terms of

"how a place used to be," and essentialised in terms of a naturally occurring and cohesive rural gemeinshaft ${ }^{13}$,

$$
\text { - (Hogg \& Carrington, 2006, p. 83) }
$$

A society with high social capital can construe problems to have originated from outside the community and can lead to the silencing of other problems, typically domestic and sexual abuse.

Shaffer and Anundsen (2005) analyse and describe communities as solid shapes. They describe the three dimensions of community below:

1. Length: How long the group has shared experiences and how committed they are to continuing that sharing

2. Breath: How many facets of life are shared, and how wide the range of people and experiences shared

\footnotetext{
${ }^{13}$ Gemienschaft - often translated as community, where individuals are orientated towards the association as much if not more than towards their own self-interest. Opposite of this would be gesellschaft where those working for their self-interest such as a modern company maintain it (Jose Harris, 2001).
}

3. Depth: How deeply, thoroughly, or intimately they share

When described as a solid object, small farming communities are usually long, quite broad but only deep at one end

Communities are formed by the choices of the individuals. They cannot be planned, nor can they happen without some sort of basis for interaction - a shared goal or common interest. This together with casual meetings in the street and community groups, be they formally defined or not, entwine to create a sense of community. Public policy and design can allow this community to flourish by the provision of local facilities and perceived safety on the streets

(Barton, et al., 2003). The existence of such local community is particularly important for young families (interaction of children to build acceptance of others), retired people (social interaction together with physical and emotional bonds) and those who are out of work (to keep their social interaction abilities).

Communities are a system of networks. Interweaving of these networks tightens and strengthens the whole system. When one strand becomes isolated both the individual and the community suffers from the weakened web (Shaffer \& Anundsen, 2005). 


\section{Deprivation and Community}

Poverty levels have social implications on the status of the community and individuals - a source of shame - socially constructed to reflect general standards of living and life expectations. As a sociological theory, deprivation is a state of poverty where people are measured by what they do and do not have, or have access to.

\section{Definition of Deprivation:}

'Deprivation is a state of observable and demonstrable disadvantage relative to the local community of the wider society or nation to which an individual, family or group belongs'

- Peter Townsend in (Salmond, Crampton, \& Atkinson, 2007, p. 36)

Deprivation is based on both material and social deficiency.

Material refers to material resources, services, the physical environment, amenities and location in life. Townsend's social deprivation refers to the roles, relationships, functions, customs, rights and responsibilities of membership of society and its subgroups.

As a socioeconomic indicator, NZDep2006 deprivation index (the index used in this thesis's empirical research) derives scores based on a weighting system - in descending order - of income, home ownership, support, employment, qualifications, living space, communication and transport (Salmond, et al., 2007). When applied to meshblocks ${ }^{14}$, this is translated into a deprivation score comparable across the country.

According to Harry Salmon (2002), it is unrealistic to expect self-help community projects to revitalize local communities, as community participation is unlikely due to the circumstances in deprived neighbourhoods and inconsistent interests of residents. Access to jobs, decent housing and public services are of more concern than engaging in a shared, time-consuming community project (Cheong, Edwards, Goulbourne, \& Solomos, 2007).

\footnotetext{
${ }^{14}$ Meshblocks are geographical units defined by Statistics New Zealand to contain a median of approximately 87 people in 2006
} 


\subsection{Community Design in Practice}

This section is an examination of the established community design principles and the notion of community acceptance through vernacular architecture. Many of the architectural theories explored are comparable to the sociological theories raised with notions of integration - physically and socially, formal and informal social interaction points, and mixed use through the convergence of communal uses.

'Successful communities are not just built, but are developed and nurtured through a synthesis of activities that include the creation of a good urban form, clear social structure, economic purpose and supported by integrated modes of transport.'

$$
- \text { (Neal, 2003, p. 82) }
$$

\section{Community Design Principles}

The design of community is alluded to throughout many urban design theories. 'Urban' design suggests that these theories of community are relevant only to the urban environment. The literature reviewed for this section suggests ways for the improvement of community in densely populated areas with no direct information on rural community design. Many of the urban theories propose methods of community design that contrast the values ${ }^{15}$ of living many rural residents. Some literary works, the likes of Trancik (1986), do not acknowledge the rural environment as having an associated community and cease recognition of community beyond the boundary to the urban. However, these design principles are not discredited for their adaptability to the rural environment.

The principles of connectivity; the creation of nodal points and places for the people; mixed use and form; flexible design; enrichment of the existing; economic viability; and vernacular context specific - design are all mentioned extensively throughout the urban design literature reviewed. The potential of these principles is explored for their subsequent application to rural community development.

The design principle of connectivity applied to the rural context is more concerned with the larger scale than the urban iterations of the theory. For the rural context, connectivity is more significant

${ }^{15}$ Rural residents do not want the increased population, crime, traffic, pollution, noise and lack of community spirit they associate with urban areas (UMR Research Limited, 2008). 
when pertaining to the options of resources as an economic necessity and social advantage beyond the local community (Field, 2008; Neal, 2003). At this scale, the architectural theory of connectivity has parallels to bridging from the sociological theory of social capital. Neal (2003) argues for a variegated not gated definition of community - a sense of belonging as well as access to opportunities further afield. Connectivity in the immediate rural context allows for more integration and density through intricacy as seen in the urban field.

The notion of density is an interesting principle to explore in the rural context. Higher density creates more opportunities for informal social interactions to occur. Yet high density equates to an "unwanted" quality for many rural residents.

Nodes are a method of counter dispersion usually of high-density mixed-use centres which are best suited, yet not limited to, community-orientated shared services such as libraries, retail, offices, hotels, post offices and government departments (Filion, 2009). Individuals, particularly children and elderly who have a relatively permanent presence in a community, need considering in the design of community nodal points. The safety and mobility of this group is paramount to the design of nodes. Sociologist Ray Oldenburg's idea of third places as gathering spaces for the community is an example of cross over between the architectural theory of nodes and his sociological theory of community interaction. These nodes are clustered points of community integration, be it formal or accidental meetings in the public domain.

Mixed use and form, along with flexible design, allow a community to develop and change over time. A mix of uses and forms create vibrancy and life. Flexibility to the design of specific buildings and their associated space allows the changes to occur in the external environment without disrupting the established. Mixed use and form combined with flexibility is efficient use of spaces as this reduces resource demands and increases economic viability for the community.

\section{Community Acceptance of Design}

Collaboration with the community throughout the design process and build is a technique for gaining acceptance of and pride in the building (Barton, et al., 2003). In the changing economic environment, this may no longer mean actual time-consuming construction but through community participation in other aspects of the facility's design. 
Another method of community acceptance is through the building's design reflecting the community's characteristics also described as vernacular design. Enrichment of the existing, economic viability and context specific design are associated with vernacular design principles. Designing for a community should respond to the surrounding environment. Embracing the language of the local architectural culture responds to the community. The community are able to identify with the building as a place that belongs in the community, and within which, the community belongs. Brian

MacKay-Lyons, Samuel Mockbee and Glenn Murcutt are successful with their design techniques in context to create vernacular architecture (Dean \& Hursley, 2005; Gusheh, Heneghan, Lassen, \& Seyama, 2009; Quantrill, 2005).

Vernacular is not a style or an image. It is a process or cultural view, connected to material culture and the culture of building. By taking up new technologies and materials the vernacular is always contemporary and forward-looking rather than sentimental or backward-looking. For the architect, to embrace the vernacular is by definition to accept the idea of convention. The conventional ways to make things, the conventional sequences and methods of the building industry become the medium of architecture.'

$$
\text { - (MacKay-Lyons, 1995, p. 9) }
$$

The common techniques for designing vernacular architecture employed by MacKay-Lyons, Mockbee and Murcutt are:

- Observations of the local building culture of the predominant industries in the area

- Ecologically responsive through building the way the locals build and use of their techniques

- Using materials used by the locals - sustainable resources easily sourced

- Ethical and moral design by incorporating materials not necessarily deemed building materials but in prevalence in the community

- Climatically responsive architecture to the individual site 'Murcutt's architecture is an Australian architecture, born of the uniqueness of his country.'

- Shoko Seyama essay Modern architecture without glass: the micro elements of Glenn Murcutt in (Gusheh, Heneghan, Lassen, \& Seyama, 2008, p. 233) 


\subsection{Community through Architecture in the Rural Context}

This chapter was an exploration into the documented theories for creating community. The parallel threads of sociological and architectural theories of community have become indistinct from one another. Throughout it has become clear that the architectura theories originate from the sociological as architectural devices for enabling community.

The cultivation of a socially wealthy community depends on many variables. The founding sociological concept is social capital. Aiding social capital building while ensuring the architecture includes the community and crosses societal boundaries bonds the local community and bridges the design with other communities. This creates a stronger network web and ultimately a more successful community, be they of urban or rural nature. The key determinants found in the literature, and those assessed in the rural context in the empirical research chapter, are:

- Deprivation: a social and material evaluation of what the community do and do not have in relation to the accepted norm of the nation. In the empirical research, this used to determine the case study community and the type of architectural intervention relevant.

- Density and development patterns: the study of the opportunities for informal social interaction concentration and connectivity. This is investigated in the sample communities against the community perception of social capital wealth.

- Service and employment opportunities: the community gathering places and nodal clusters of these for formal social interaction. Again, this is assessed against the perceived community's social capital wealth.

- Vernacular: explores community acceptance of design through the agricultural identity of the case study community

- Community Hall Typology: precedential rural community works looking at their success or failure in continued support and identification with their community - the flexibility of their design to address the community as it has changed 
4.0 Empirical Research: 
The following sections of empirical research investigate

determinants for community in the rural context. Due to the lack of direct information for rural community design from the sociological and architectural literature reviewed, empirical research applies the current community theories onto the rural context of Northland, New Zealand.

The first section, 4.1 Empirical Research: Community Spirit, studies the three sample communities of Titoki, Maungatapere and Maungakaramea (refer to Appendix I: Sample Communities, 1.1). These communities were chosen to derive links between the literature theories reviewed for quantifying community as they display varying levels of community. The investigations focus on Peter Townsend's deprivation theory in 4.1.1; density and development in 4.1.2; and Ray Oldenburg's Third Places theory for services and employment opportunities in 4.1.3. These, combined with the community perceptions (refer below), gave focus to the following section, 4.2 Empirical Research: the Rural Context. These final two sections of empirical look into identity of the rural resident from their established agricultural working environment and community-minded projects as common ground. They focus on Titoki and surrounding rural communities in 4.2.1 rural vernacular architecture, and 4.2 .2 community hall typology. These investigations help to determine the qualities of the architectural interpretations of the sociological theories to define specific criteria for the cultivation of rural community through architecture.

\section{Community Perception}

Insight into the communities' perception was gained through interviews with a cross section of members from the aforementioned communities. The perception of community is based on the knowledge of individual members within the sample communities. Their knowledge is that of their experience of their own community, as well as how they perceive the communities around them (refer to Appendix I: Sample Communities, 1.2 - 1.4). The sample group of interviewees were selected as to their relationship to the community. The participant groups were:

- Local business operators

- Established residents

- $\quad$ Share milkers/herd managers

- School representatives

- Recent immigrants to the community

- Agricultural consultants 
Along with participants from each of these groups, impartial views were also obtained through interviews with members of transient association to the communities. Of those who participated in the formal interviews, it was not deemed crucial as to their gender, age or ethnic background. The sample group represents both genders and a range of ages and ethnic backgrounds, including Maori. The most challenging limitation came from those who were not passionate or interested in their community as they were difficult to persuade to give information.

The three communities all mentioned varied involvement of the community members in community life. All of the communities remarked on the involvement of the established families in providing a nucleus of active involvement for the area, while the newer residents to the areas were not as eager to be involved.

Titoki felt they were lacking in opportunities to get involved in the community as a whole, Maungatapere saw themselves as in a time of renewal with younger generations beginning to bind the community and Maungakaramea appeared to have a more visible and vocal community core. The overall perception of community in Titoki is waning, Maungatapere moderate, and Maungakaramea demonstrating the highest level of community.
The opinions held by many of the interviewees for Titoki was one of depopulation leading to a lack of involvement. While many

members of the Titoki community did socialise in the area, they did feel the need for a common socialising ground. Many individuals were aware of the marae at Titoki. This seemingly passing comment was made by both those in the community and by others to indicate the community has a strong Maori culture based at their marae (including a wharenui ${ }^{16}$ and wharekai ${ }^{17}$ ).

\footnotetext{
${ }^{16}$ Meeting house

${ }^{17}$ Dining hall
} 
4.1 Empirical Research: Community Spirit 


\subsubsection{Deprivation}

'Indexes of deprivation are used by community groups and community-based service providers to describe the populations they serve, and to advocate for extra resources for community-based services.'

$$
\text { - (Salmond, et al., 2007, p. 15) }
$$

This study investigates the sociological theory of the deprivation index's link to community spirit. NZDep2006 deprivation index scores are used as a socioeconomic indicator reflecting nine variables of the eight dimensions of deprivation from the 2006 census (Statistics New Zealand, 2006). The deprivation score's relationship to community spirit is examined down to a more definable level (refer to Appendix II: Deprivation Index Determinants data). This attributes the discrepancy in community to the variables individually.

The NZDep2006 index is an ordinal scale ranging from 1 to 10 where 1 represents the meshblocks with the least deprived score. This divides New Zealand into tenths indicating that a meshblock with a score of 10 will be in the most deprived scoring 10 per cent of areas in New Zealand (refer to Appendix II: Deprivation, 2.2 Deprivation Distribution).

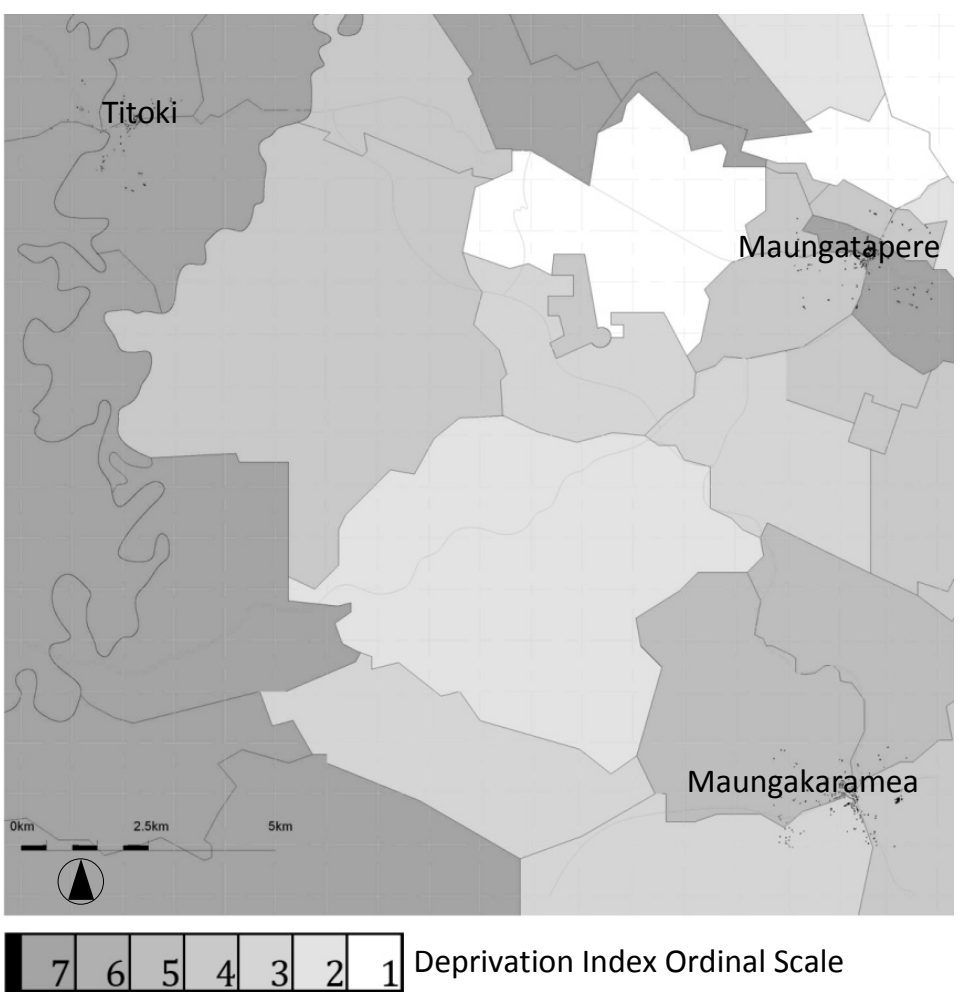

4.1.1a Deprivation Index Community Context

Source: derived from (Statistics New Zealand, 2006) 

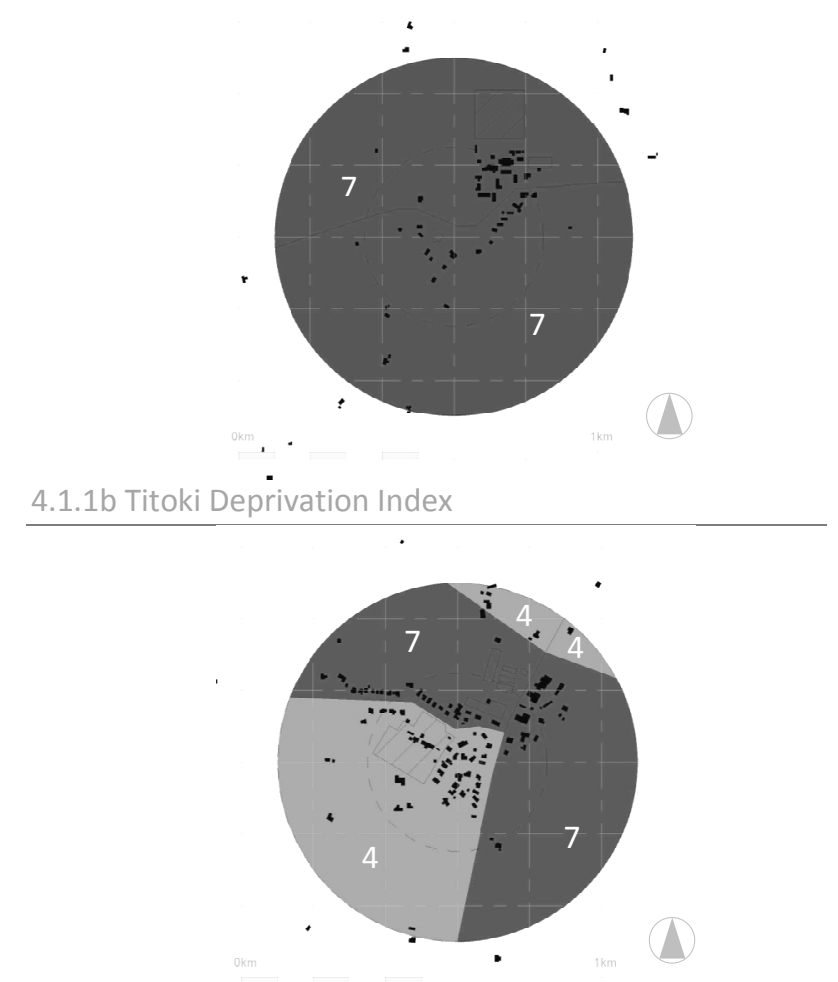

4.1.1c Maungatapere Deprivation Index

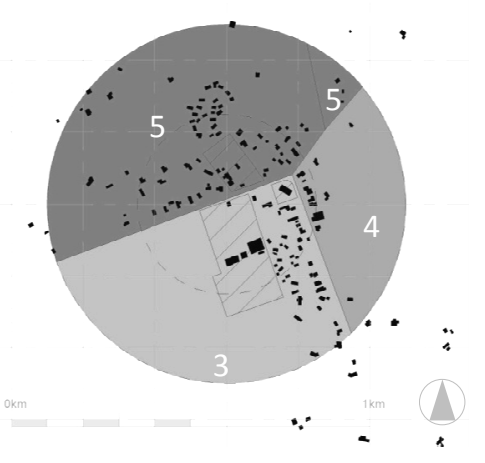

4.1.1d Maungakaramea Deprivation Index

\section{Sample Communities}

Each of the studied communities are made up of multiple meshblocks (refer to 4.1.1b, c and d).

Average Deprivation Scores for the Sample Communities:

Titoki

7.0

Maungatapere

Maungakaramea

Statistics New Zealand releases the individual statistics for regions opposed to comprehensive statistics for the individual meshblocks. For this reason, the Index Determinant Data table of Appendix II investigates the 'QuickStats' for each of the communities based on their associated Statistics New Zealand region. The OpoutekeTanekaha region covers Titoki; Maungatapere is represented by a region named as Maungatapere yet this extends out beyond the actual community; and Maungakaramea is in the WharekoheOakleigh region.

The sample communities have a homogenous demographic. Ethnically, their population is predominately European, with a very traditional family structure, are in their own homes and have greater access to vehicles. The communities also have higher than the national average access to the likes of the internet, cell phone and fax machine technology. As mentioned, technology removes 
isolation for communities, and reduces voluntary community building and mutual support.

The most notable difference in the associated Titoki region is the population has a higher percentage of under 15's combined with the lower over-65 population making for a relatively young population. This explains the higher than average household size when coupled with the high 51 per cent couples with children rate. The statistics suggest there is a possibility that they find their support from within their immediate home environment and through technology ${ }^{18}$. A high level of bonding within the immediate home may not see Titoki seek mutual support from the community leading to the waning community perception.

In Maungakaramea (Wharekohe-Oakleigh region), the population has more individuals born overseas, a greater number of one-person households, a lower unemployment rate, and a higher median income. This suggests that the individuals in the Maungakaramea community may look out beyond their home environment to find mutual support from the community. Immigrants in low numbers integrate themselves into the established community for support in their new environment. Likewise, the social isolation of solo living is

${ }^{18}$ Younger population with increased access to technology may exacerbate the reduced voluntary community, as they tend to comprehend and use technology more than an older population. consciously offset by developing supportive social networks (Walker \& Hiller, 2007). This suggests a more active body of residents in the Maungakaramea community leading to their high-perceived community spirit. This does not support the established residents' perceptions as they see the new immigrants as not willing to become involved in the community.

\section{Conclusion}

Titoki, with its high deprivation score and low community perception, is a community who need to activate the members that are already there to participate in the wider community. This sociological problem translates architecturally into providing opportunities to interact in areas that concern them. Architectural focus on public services in health and finances, rather than self-help and community programmes, may create a greater stimulus for community involvement and use of the local community environment. These opportunities for social interaction aid the mutual support mentality of the community. Employment in the rural areas is lowest in the service industry, particularly health and community services and can be capitalised on in a "deprived" community. 


\subsubsection{Density \& Development}

This section examines density and development patterns affect on community in the rural context. As mentioned in 3.2 Community Design in Practice, community design principles concerned with density are often not applied to the rural context. The density of a community affects the amenity values, development patterns and the number of opportunities for informal social interaction. Built density promotes the sociological theory of informal social interactions building social capital.

The derived figure-ground plans ${ }^{19}$ of the three sample communities were examined as to their density and development patterns. The community perceptions were then assessed against this. Density was determined by the number of built forms per hectare within the concentric circles ${ }^{20}$ and out into a wider grid as rural communities are inherently dependent on vehicles. In the diagrams 4.1.2 a, b \& c: the darker the region, the more built form density in the region. The relationship between the figures and to the ground provides a development pattern. This development pattern was then assessed against the WDC environment zones.

\footnotetext{
${ }^{19}$ All built form is shown in black (figure) and open space as white (ground). Derived from GeoEye (2010).

${ }^{20}$ Central $500 \mathrm{~m}$ diameter circle of the communities was determined by where the community was most dense as a whole. The post office did not
} determine this, as these were not present in all of the communities.
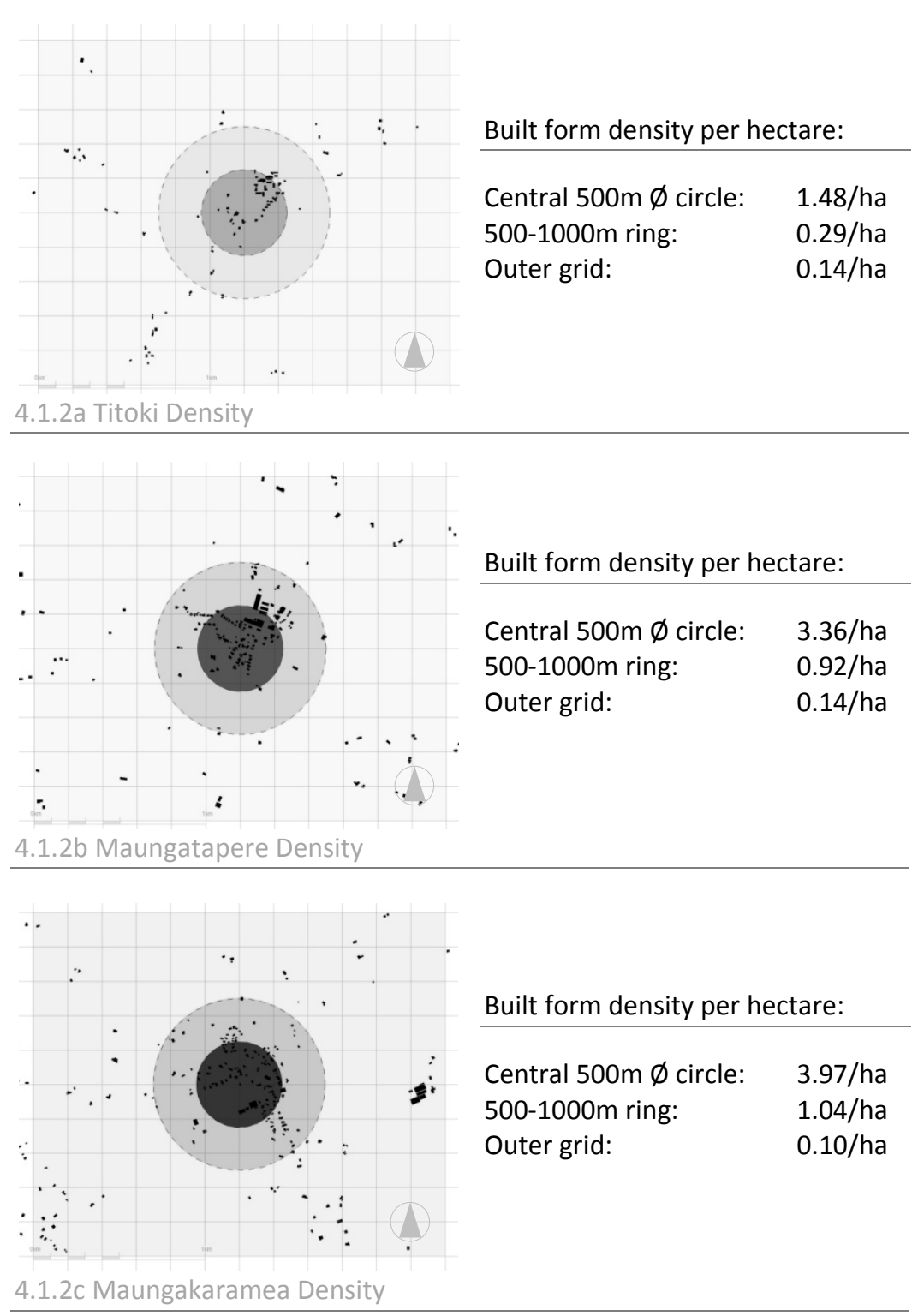


\section{Density}

Titoki's density is the lowest of the three communities studied with only 1.48 buildings per hectare in the central $500 \mathrm{~m}$ diameter circle, under half that of the other two communities. From this central circle, the density lessens to 0.29 buildings per hectare in the outer $500-1000$ m diameter ring, a reduction of 80 per cent. The outer grid has only 0.14 buildings per hectare, a reduction of a further 52 per cent for a total peripheral reduction of 91 per cent from the centre.

Maungatapere's density is 3.36 buildings per hectare in the central $500 \mathrm{~m}$ diameter circle. This reduces by 72 per cent to 0.92 buildings per hectare in the $500-1000 \mathrm{~m}$ diameter ring. Maungatapere's density has a reduction down to 0.14 buildings per hectare in the outer grid, a further reduction of 84 per cent, and a total reduction of 96 percent in density from the centre of the community to beyond $1 \mathrm{~km}$.

Maungakaramea is the densest community studied and the highest perceived community spirit. The central $500 m$ diameter circle has a density of 3.97 buildings per hectare. The 500-1000m diameter ring shows a reduction of building density to 1.04 buildings per hectare (74 per cent reduction). The outer grid reduces to 0.10 buildings per hectare, a further reduction of 90 per cent to a total reduction of 97 per cent density of the community from its centre to periphery.

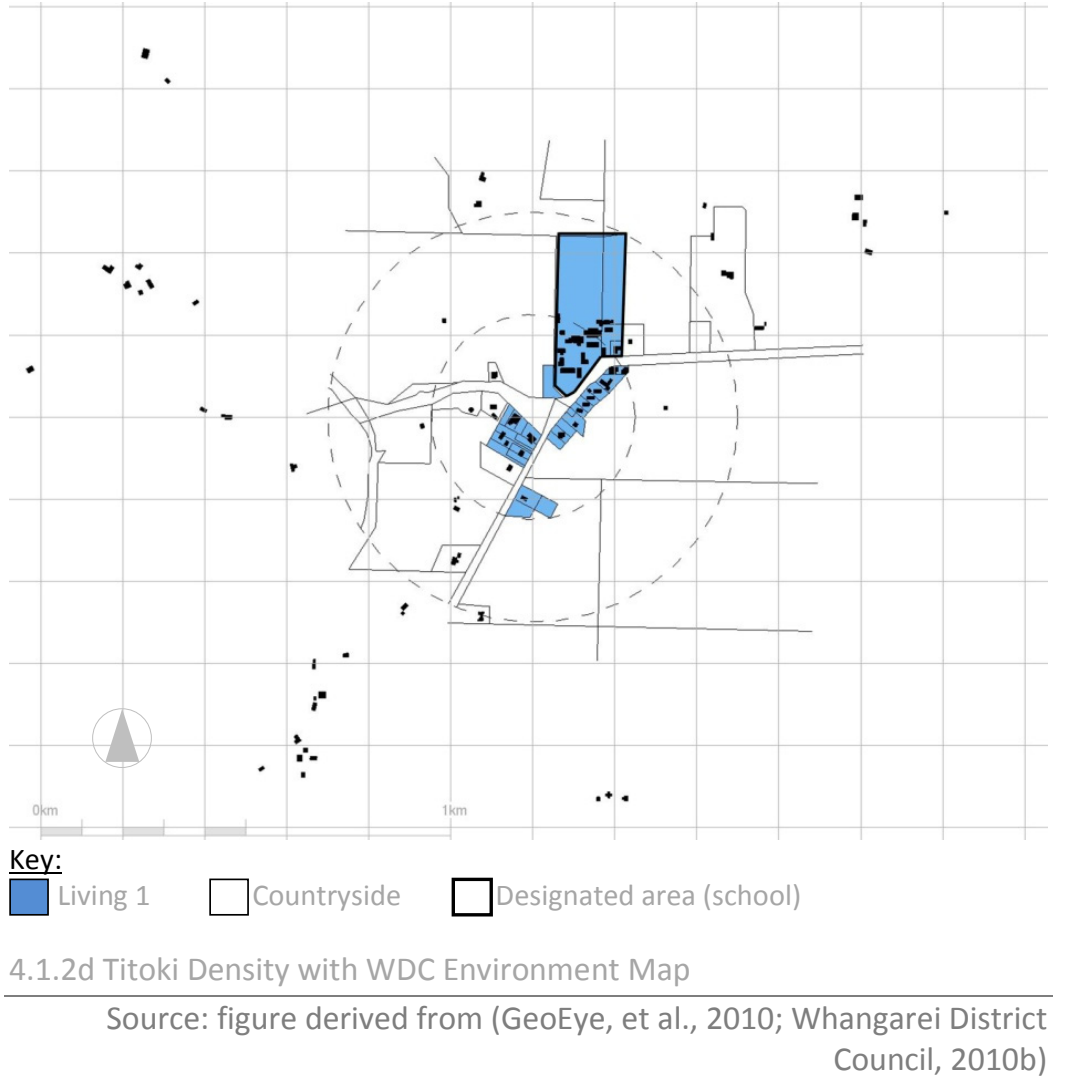

\section{Development Pattern}

Titoki has the least density reduction from its centre. This is coupled with the current pattern of development along the edge of the main road, further spreading the community thinly. The development pattern of Titoki relates heavily to the surrounding land conditions. Much of the surrounding farming land is profitable land for the farmers due to the soil type and flat topography to the north and east of the community. Thus, the surrounding land owners would 
not wish to see their paddocks reduced. If they do require more capital, it is cheaper for the farmer to subdivide lots with

infrastructure already in place, i.e. road access off the edges of their properties, than for them to propose dense centralized communities where they will need to provide such amenities to get consent.

Land to the northwest of the main road would be difficult to develop due to the steep gully landform.

In Titoki, many of the buildings orientate their long edge to the north to maximize sun exposure. This building pattern has not produced a built street edge, nor do the current dwellings relate easily to the street. Many are set back in their lots and the garage is the only built form of the dwelling to address the street.

Titoki appears to be in danger of life style block ribbon development along the existing roads and spreading out away from the centre of the existing community. This type of sprawl could be particularly harmful for the community as reliance on the vehicle reduces informal interaction. Perhaps the WDC's intervention of the UTE zone can help to prevent this from spreading the focus of the rural community. The key aims of keeping rural land productive and preserving the rural amenities would benefit these areas to prevent development occurring along the roadsides.
Maungatapere and Maungakaramea show a similar pattern of ribbon development along their main roads yet is mitigated by some smaller secondary streets knitting the community together, allowing for densification of a centre.

\section{Conclusion}

Density appears to relate to perceived community spirit. The higher the density and centralization of a community, the greater the community spirit will be. Titoki has the lowest density in the central $500 \mathrm{~m}$ diameter circle by under a half of that of the other two communities. This suggests that there are physically less people in the area for informal social interactions to occur. All three communities showed a similar density to the periphery of the communities' suggesting similar isolation and growth patterns beyond the community centres themselves.

The local council's environment plans have affected the development of the community layout. Currently there is no street edge development and no real restriction on sprawl development occurring along main road edges. Due to the current living 1 and countryside zonings, development is been left up to the discretion of the landowner. This has left the community of Titoki with property lots where future development is limited and lends itself towards sprawl and low-density ribbon development. 
The level of interdependency and self-sufficiency - linked to social capital - in a community affects the perceived quantity and quality of community spirit. Demands, such as employment, education and opportunities for social interaction, are all important factors as these aid social capital building. This section explores Ray Oldenburg's sociological theory on the availability of 'second' and 'third' places in the community for building social capital. These places are the architectural translation of the sociological theory of formal social interaction points. Their quantity and placement helps to build social capital.

\section{To quantify social capital building potential in each of the sample} communities, all service and employment opportunities are mapped as shown in figures 4.1.3a, b and c (figures derived from GeoEye (2010) and site visits April 2010). The buildings are categorized within the concentric circles and grid in to:

\section{Opportunities Key:}

$\square$ Derelict Building

Commercial

Rural Employment

Community Open Space
Community Building

School

Church

Residential
As it was found in the literature that rural communities are

dependent on the wider community for resources. For this, a study was also undertaken exploring the number and distance of businesses advertising to serve the sample communities (refer to 4.1.3d, e and f and Appendix III: Services and Employment Opportunities for full listings of businesses advertised in the areas).

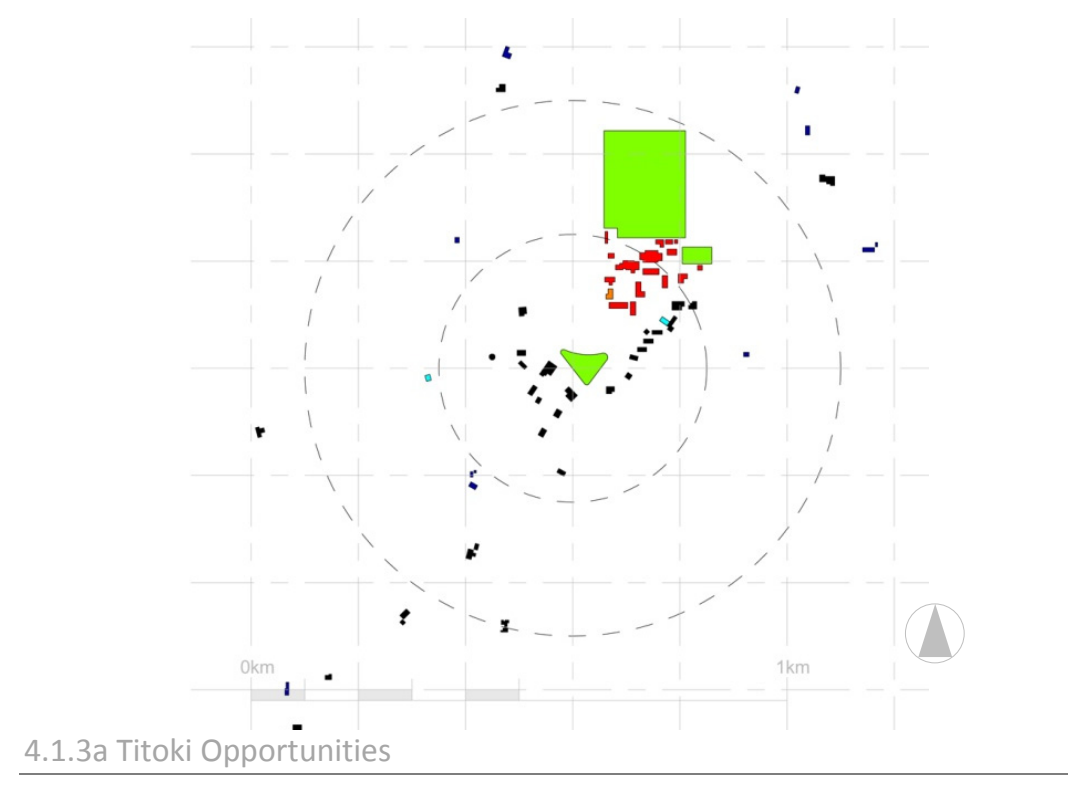



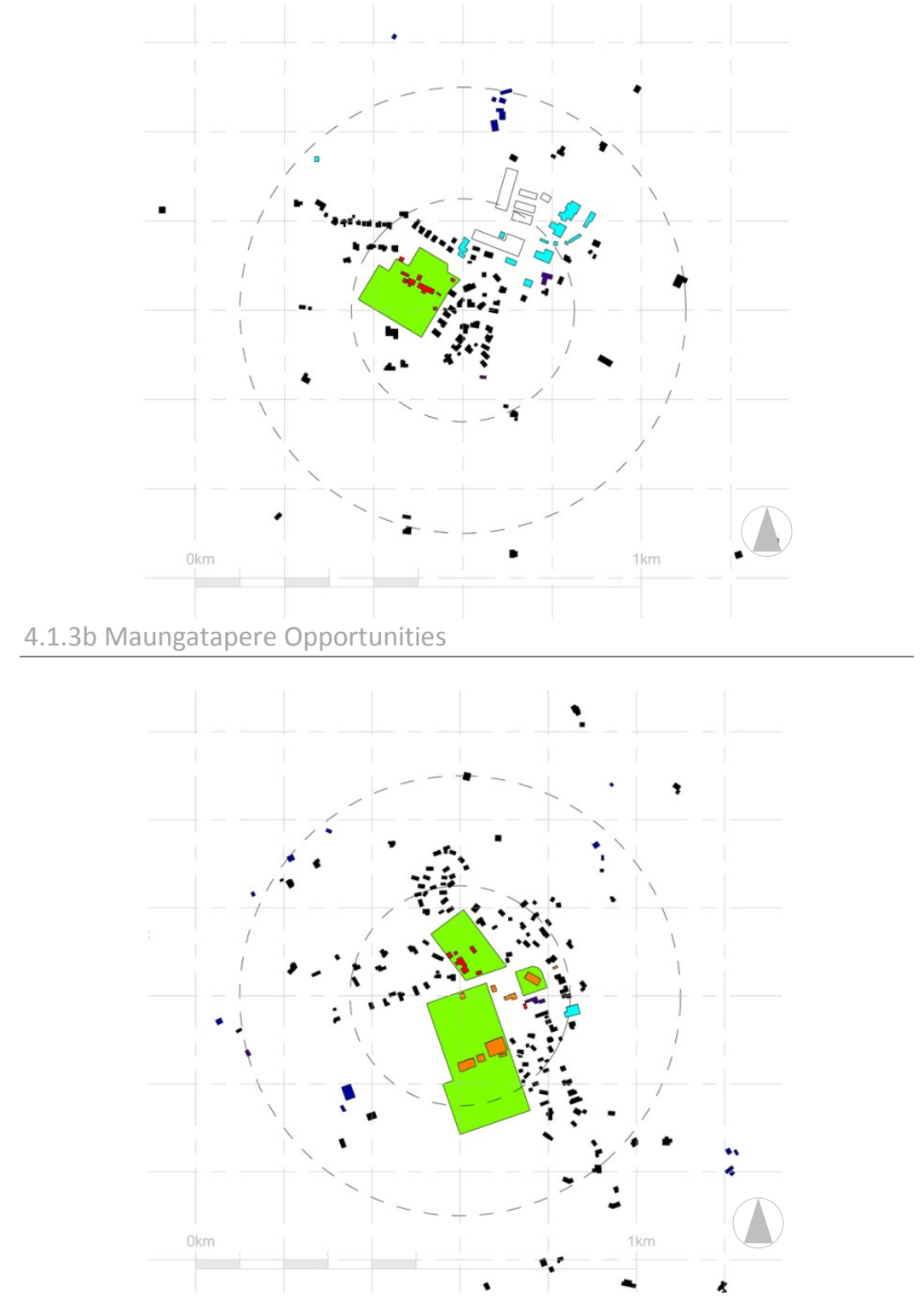

4.1.3c Maungakaramea Opportunities

\section{Opportunities}

Titoki

Titoki exhibited only four separate examples of services and employment in the central 500m diameter circle - the school, the associated community library at the school, the pre-school and the general store. Public amenities for Titoki are the tennis courts, school fields and an open area in the intersection. The conditions of these environments are not welcoming with the tennis courts and fields being within the school grounds and hidden behind the school buildings while the picnic area is leftover space when the roads were built. Beyond this, there is a scattered pattern of rural employment opportunities across the grid with no definition to the centre of the community.

The rural employment opportunities are 93 per cent of all employment opportunities around Titoki based on the number of built forms. This suggests that the community is heavily reliant on the rural sector for its employment. Historically, three other employment opportunities were in the central Titoki circle, these have relocated or been demolished. There is no perceivable business development pattern outside the general store's proximity to the school. A directory search for businesses serving the Titoki area only offered five hits; three of these have already been identified as within the Titoki community. The other two businesses 
are Gavin's' Apiaries Limited, $1.5 \mathrm{~km}$ from Titoki and the Mangakahia Sports Complex $8 \mathrm{~km}$ away. Refer to $4.1 .3 \mathrm{~d}$ below where the each line represents a business or public amenity and the distance of these from the community is the length.

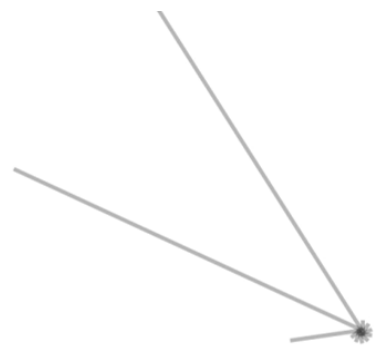

4.1.3d Number and Distance of Services and Businesses from Titoki

\section{Maungatapere}

Maungatapere showed to have ten opportunities for services and employment within its central 500m diameter circle - the majority commercial employment opportunities. For Maungatapere, the overall centre of density does not align with the centre of the service and employment opportunities density. In general, there is a more defined centre of the commercial development in Maungatapere. This commercial concentration is linked to Maungatapere's rural distribution potential (located at a cross road of a State Highway and a main connecting road).

Across the whole grid, Maungatapere does not show the rural employment opportunities to the same degree as seen with Titoki with only eight rural employment buildings ( 31 per cent of total employment opportunity built form). This suggests that the Maungatapere community relies heavily on commuting out of the community to source employment. The Maungatapere community is served by twenty-nine separate businesses ranging from Hotels and Taverns to Architectural Designers; and supported by seven community-orientated services (refer below to 4.1.3e).

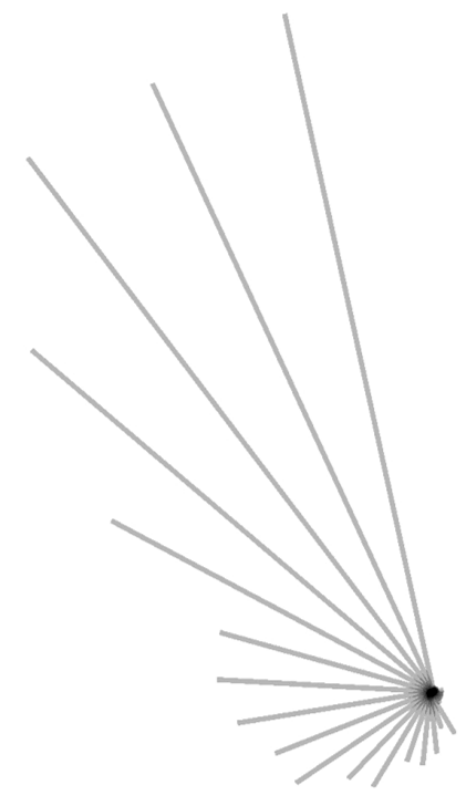

4.1.3e Number and Distance of Services and Businesses from Maungatapere

\section{Maungakaramea}

Maungakaramea exhibits the most defined and aligned centre of employment and service opportunities for the community within the central circle of overall density. As with Maungatapere,

Maungakaramea has ten opportunities although only one is 
commercial. The remainder are services provided for the

community through churches, sporting facilities and clubs, volunteer associations, and public schooling ventures. The commercial

business mentioned above also serves as the post shop as well as the local store, hire centre and mechanics garage.

Again, Maungakaramea, at 57 per cent, does not show the same level of rural employment opportunities concentration around the periphery as seen in Titoki. With Maungakaramea having the highest perceived community spirit, this information suggests that the higher the number of community-orientated services and the greater the concentration of these in align with the density of the community; the more community spirit there will be.

Maungakaramea has twelve community-orientated services and eighteen businesses listed as serving the area (refer to 4.1.3f below).

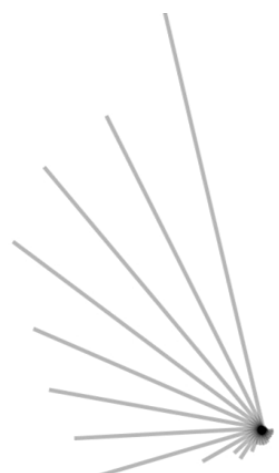

4.1.3f Number and Distance of Services and Businesses from Maungakaramea

\section{Conclusion}

The higher the concentration of second and third places within the community, the more social capital can be cultivated. The number of workplaces within the community is not as important as the number of community-orientated ventures for community spirit. A high number of community-orientated services within a rural community is linked to community perception within the sample rural communities. As employment of rural communities tends to come from rural employment opportunities, this would explain why the number of other employment opportunities within the community is not as important for community as services. As the traditional employment of rural communities is predicted to change, more employment opportunities will need to come from the local community to keep the residents working within the area. This will help the community be self-sufficient and interdependent. If employment is increased along with the number of communityorientated services available, community spirit should increase according to the sample communities studied. This conclusion has limitations, as some rural residents chose to live rurally for the lifestyle, not for the characteristics of a satellite urban town. 
4.2 Empirical Research: the Rural Context 
'The vernacular is what you do when you can't afford to get

it wrong. ... there's a kind of intelligence that comes from

that high stakes game of not having a lot of resources to spare.'

- Brian MacKay-Lyons in the $\mathrm{e}^{2}$ design series: 'the village architect' by (Westrate, 2007).

Rural vernacular architecture is the buildings around the community with which the residents accept as belonging in their environment. These buildings belong in the environment and are a representation of the community. This section focuses on Titoki as the sample community as they have been identified in the earlier sociological empirical research as the community in need of an architectural intervention to enable community cultivation. The vernacular is based on Titoki's rural community definition as of the agricultural farming landscape. The buildings of this agricultural landscape are ones the local residents interact with on a daily basis, and in a community where they are heavily dependent on the rural industries, this is the farm-shed.

The vernacular of the farm-shed is not specific to the area; it has its base in the colonisation of New Zealand. New Zealand does not have a distinct architectural vernacular specific to each area. The traditional shed design in Southland and Northland are so similar that there is no uniqueness to either therefore; the vernacular in this thesis refers to the vernacular of the agricultural shed.

An investigation into the vernacular is a guide in the architecture, not a boundary. By analysing the rural vernacular, as Mackay-Lyons, Mockbee and Murcutt have, provides precedential techniques for identifying the specific character of the sample community. The tangible aspects of the rural vernacular form part of an architectural palette of techniques, materials and aesthetics familiar to the community. By the architecture expressing these, the community will be more accepting of the design.

This study focuses on the common rural practices of construction and engineering in the farming buildings and their inherent aesthetics from the surrounding Titoki district. Twelve buildings were studied as to their construction and features that make them rural vernacular buildings (refer to Appendix IV: Rural Vernacular Architecture for data collected and documentation of the sheds).

Seventy five per cent of the buildings were gable forms (refer to 4.2.1a) with a mixture of vertical corrugated iron, timber or concrete block cladding. All but one of the studied rural buildings 

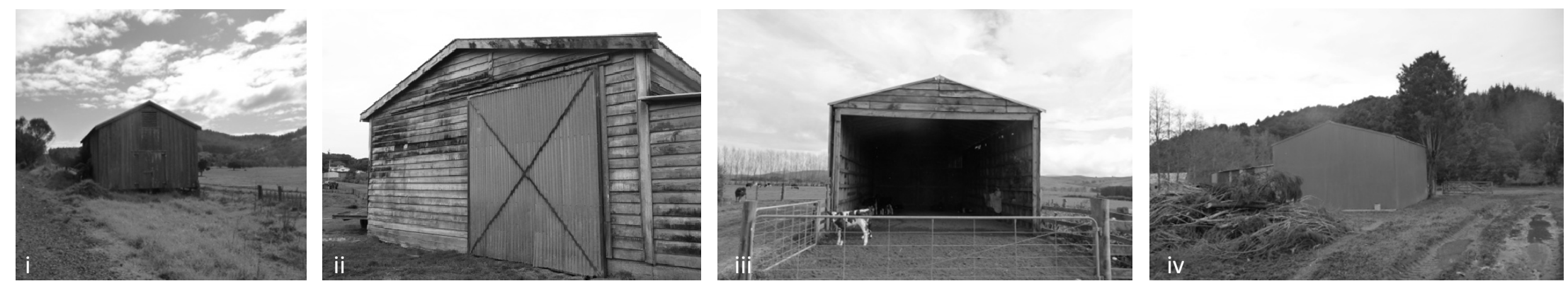

4.2.1a: Rural Vernacular - Gable form
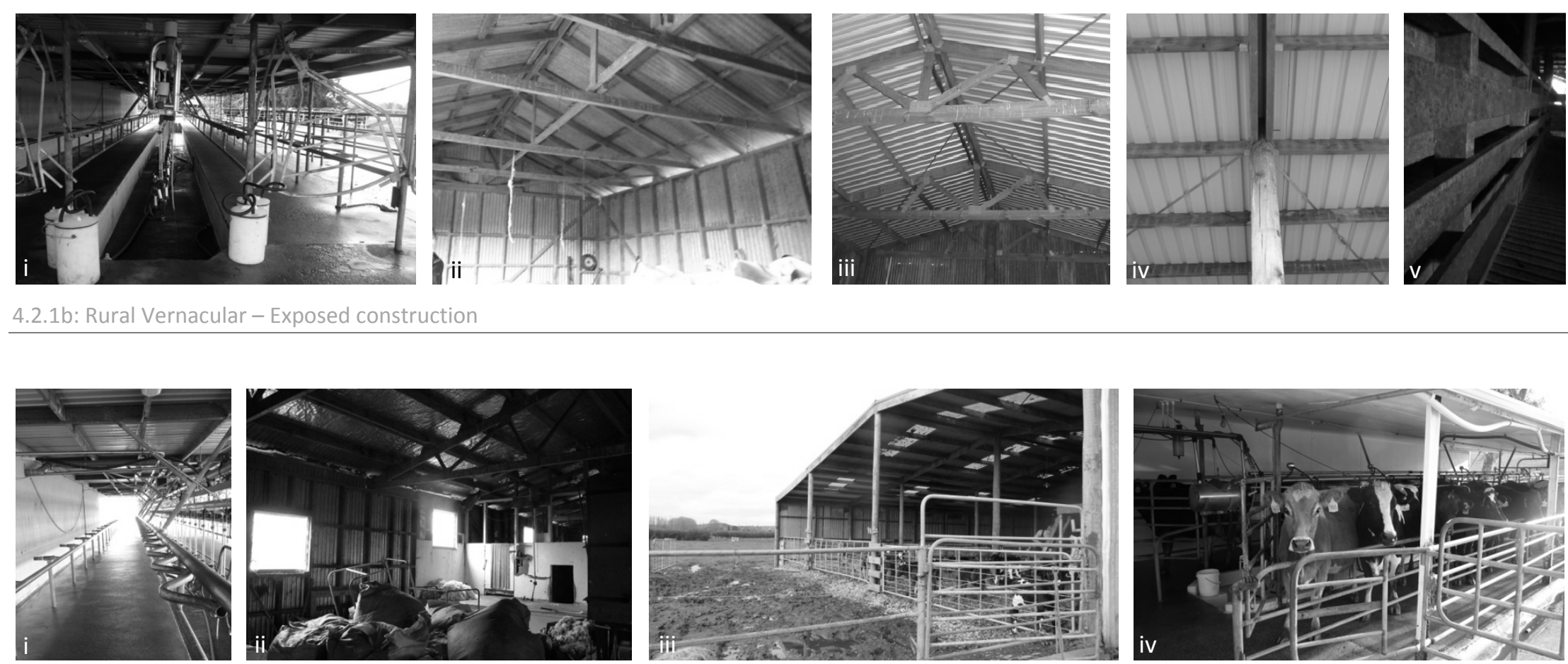

4.2.1b: Rural Vernacular - Exposed construction
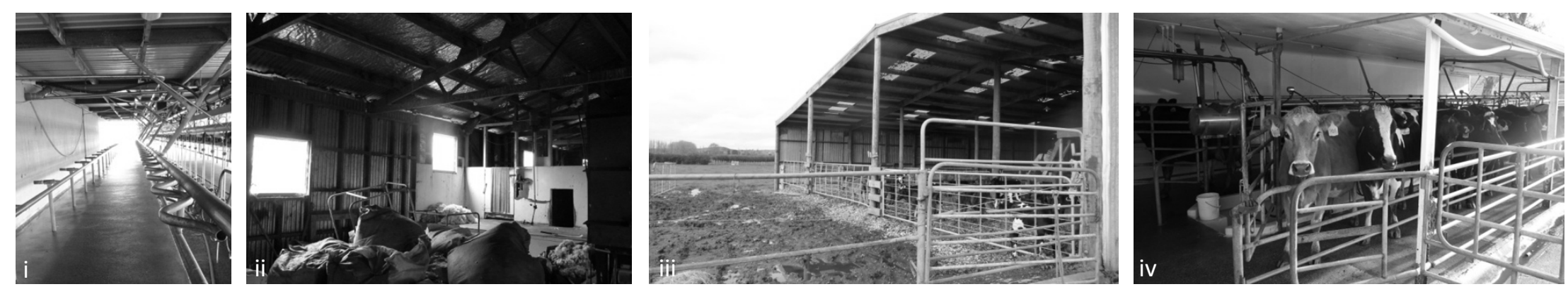

4.2.1c: Rural Vernacular - Independent secondary structure

Above images sourced from personal collection (Fraser, 2010). 
had exposed construction (refer to 4.2.1b), which usually consisted of main structural portal frames with girt rails spanning between to host the exterior cladding. Much of the secondary framing was freestanding or easily removable to reuse the shed for a different function if the need arose (refer to 4.2.1c). All roofing materials were of corrugated iron. Most of the buildings had no overhang, nor did they collect their roof water.

The majority of the buildings were open ended to one gable end (refer to 4.2.1aiii and ciii) with only lockable gates to enclose the space yet not fully as above most gates it is open to the roof. If doors were present, either they were hinged or, most commonly, large top-hung sliding elements (refer to 4.2.1aii). The natural interior light came through the open faces of the buildings or through transparent polycarbonate panels in either the roof and/or walls (refer to 4.2.1ciii). Some of the most eerie lighting was that which came through the open construction method where the wall met the roof (refer to $4.2 .1 \mathrm{bii}$ ) and either the reuse of some materials such as iron that already had pervious holes or the dilapidated state of the material - sunlight is able to penetrate through into the interior in a dappled effect. This open construction was seen in all but two buildings and appears to be the main way besides the open end - to allow for the ventilation of the spaces.

The flooring type for all the buildings was of the most practical for the use of the building. The milking sheds all had concrete pads for them to be easily cleaned, and all of calf rearing sheds had compacted metal floors with bedding such as wood chip or peelings lain over top. The woolshed studied showed a varying floor type of tongue and grove timber floor for a smooth finish where the shearers worked and open timber slats where sheep are penned and kept dry prior to shearing. Timber flooring construction was only seen in the buildings where it was essential that the space be kept dry.

These tangible aspects for design are a basis for creating the intangible qualities concerning the farm-shed architecture already associated with the community's collective identity. These reoccurring qualities of construction demonstrate the qualities usually found in the community's buildings. This palette is a tool for relating to the established community and to help design an accepted building. 
The rural community hall is an example of a gathering place and common-shared space in many rural communities. This section investigates the traditional proportions and layout of rura community halls to establish their reoccurring identity.

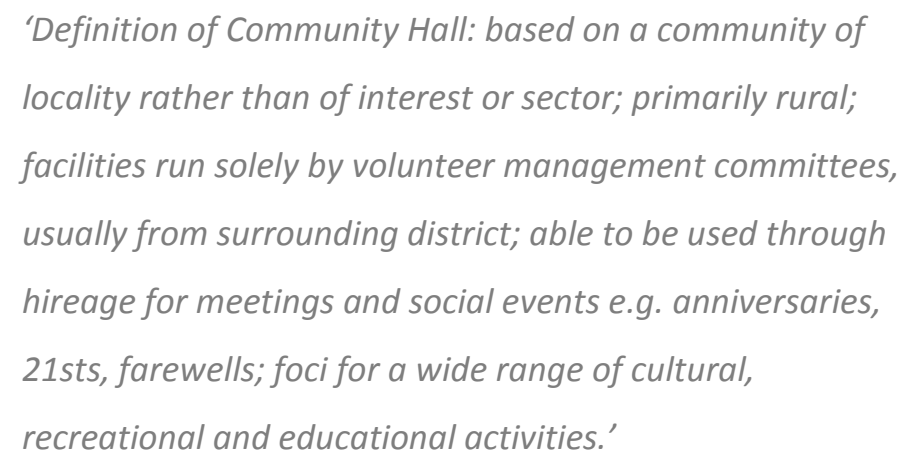

Many community halls across New Zealand are war memorial halls for the Second World War - a utilitarian memorial to honour those killed in the war (Jack, 2010). As cultural and geographical landmarks, these war memorial halls are iconic to the landscape of this country. They tell of the history of the area, built by the community for the community. While the halls studied are not solely war memorial halls, they all tell a story of the community.
A survey of the rural halls throughout the immediate district of Whangarei was performed to provide a measureable base for the tangible aspects of community design - the concrete aspects that the community recognizes and associates with their local environment (refer to Appendix V: Community Hall Typology for assessment criteria, data collected, evaluations and documentation of the halls). The halls studied, while not being innovative architecture, reflect the vernacular of the community hall. This research concentrated on the community halls as defined by the WDC (quoted) serving the community as a whole. The focus of this research is to determine definable reiterations in rural community hall design ascertaining to the identity of such built work in the community environment. Elements of their design such as proportion, volume, area, form, construction and materials, site and internal layout, position in community, and relationship to street were assessed to identify aspects of design that are associated with the identity of community halls. These were assessed in relation to maintenance of the halls to determine if there is a relationship between the design and the level of community support of the facilities. This can be linked to community spirit as community involvement is fostered through recognition and identification with such facilities. 


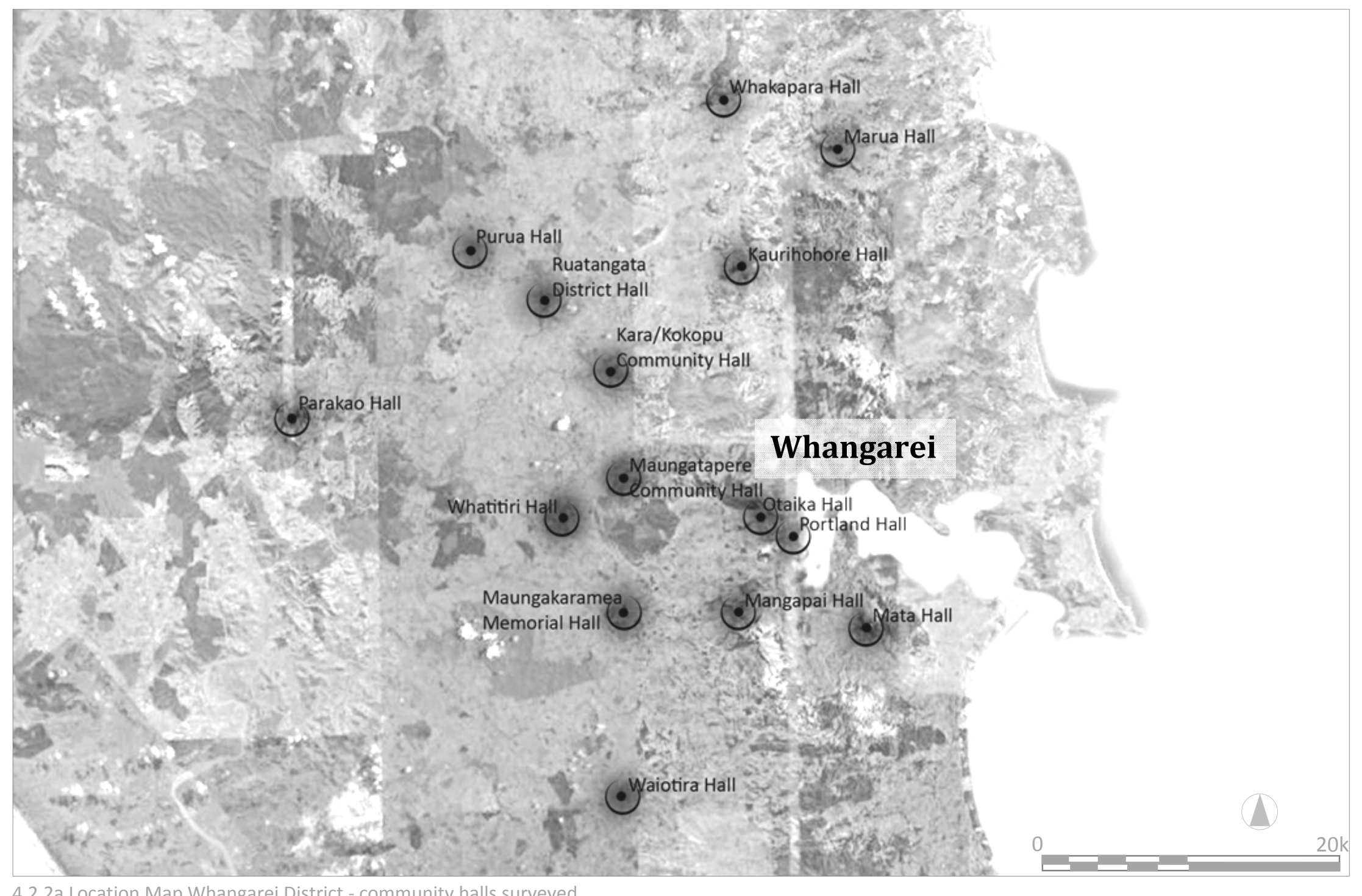

4.2.2a Location Map Whangarei District - community halls surveyed 


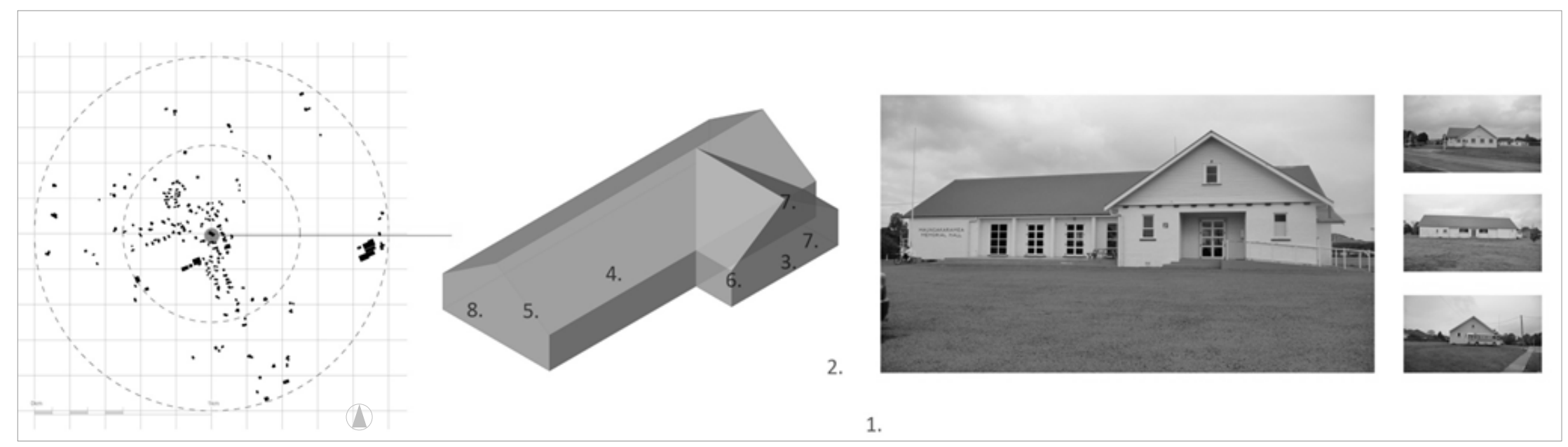

4.2.2b Successful Community Hall - Maungakaramea Memorial Hall

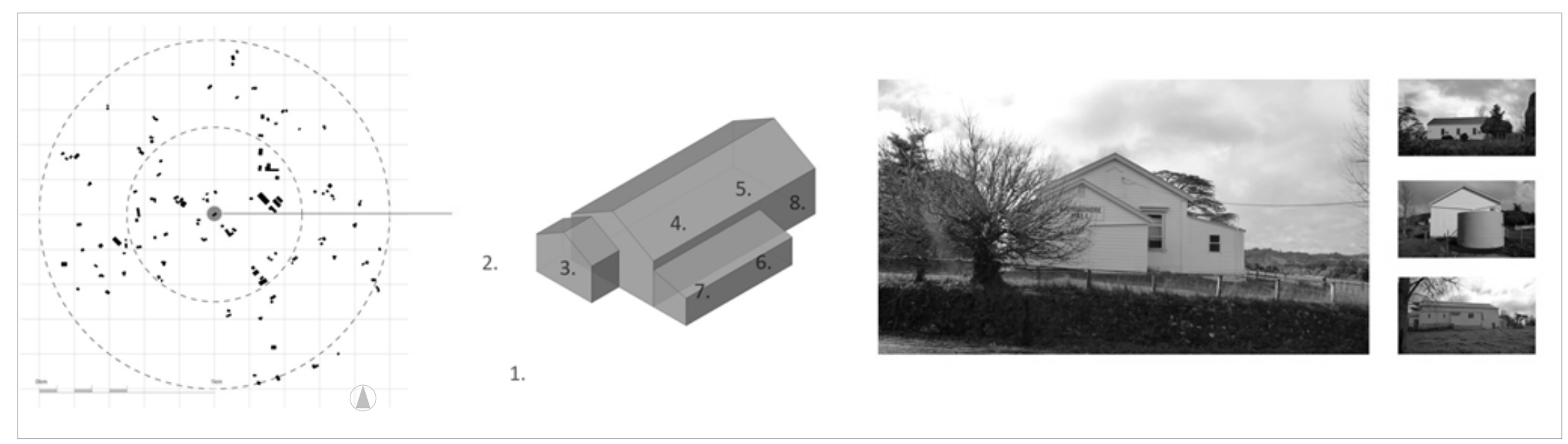

4.2.2c Successful Community Hall - Kaurihohore Hall

Layout Key: 1. Road 2. Car park 3. Entrance foyer 4 . Main Hall Body 5.Stage 6. Kitchen 7.Toilets 8.Storage 


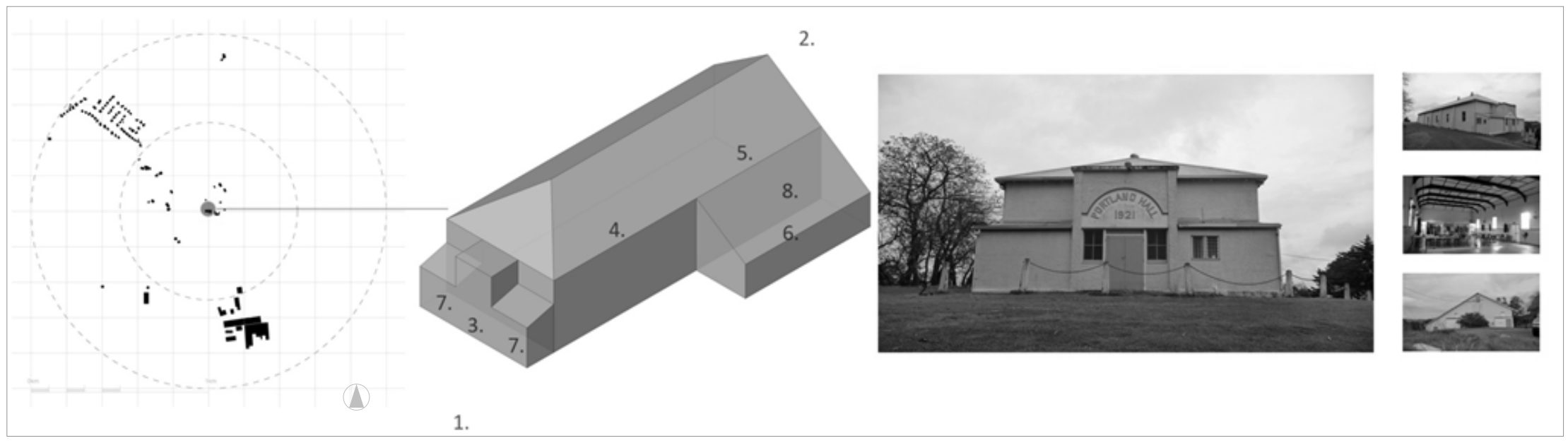

4.2.2d Less Successful Community Hall - Portland Hall

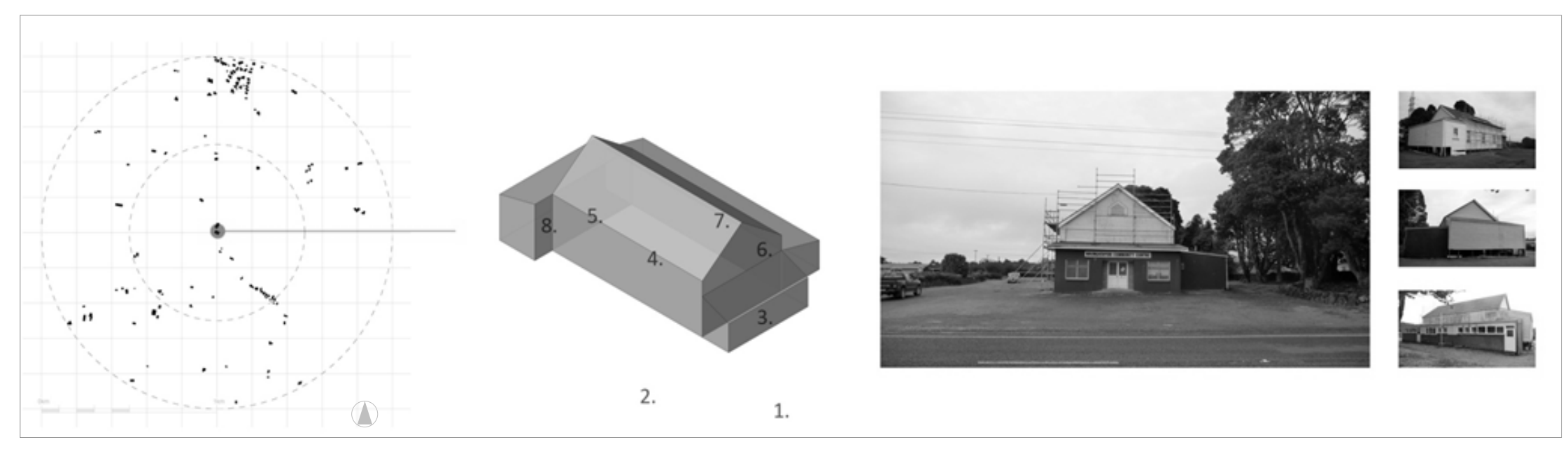

4.2.2e Less Successful Community Hall - Maungatapere Community Hall

Layout Key: 1. Road 2. Car park 3. Entrance foyer 4. Main Hall Body 5. Stage $\quad 6$. Kitchen 7.Toilets 8.Storage 


\section{Evaluation of Halls}

The most successful halls (examples of the two most successful in 4.2.2b and c) of the fifteen surveyed are, with one exception, all community-owned buildings on community-owned land. This suggests that community ownership of the facility encourages preservation and continued care of the halls. The exception to this is Maungakaramea Memorial Hall, a community-owned building on Crown land. These halls were generally central to the community, on highly visible sites off the community's main road.

One hall of notable neglect is the Portland Hall (refer 4.2.2d). This hall is a community-owned building situated on Council owned land. The hall is situated on a large lot in comparison to the hall itself and is isolated away from the Portland community. This isolation from the community and other community-based services coupled with the hall's physical isolation on the site (removed from the road and lack of development of other community-based services) sees the hall face similar issues of ownership. The community may not see the hall as utilizable or worth maintaining, as it currently has no chance of becoming a hub to the community.

Of all the community halls assessed, Maungatapere Community Hall appeared to be in the worst state (refer to 4.2.2e). The hall had been neglected for some years leading to rotting timber in the main body of the hall and broken windows - general disregard for the buildings condition and maintenance. A reroofing project was underway when the hall was visited in July 2010 but in the opinion of the author from external observation, repair of the hall to a prominent stance in the community will require much work and financing. Maungatapere Community Hall is on the periphery of the township and removed from the other main community-based services. What is interesting about this hall and its state of neglect is the building and land are currently owned by the WDC and not by the community themselves. This sense of ownership may have caused issues surrounding the upkeep of the hall.

In terms of hall size, the most successful halls median ${ }^{21}$ size was $160 \mathrm{~m}^{2}$ with a median width of $9 \mathrm{~m}$ and depth of $19.9 \mathrm{~m}$. Those halls that were not as successful tended to be larger - median hall area of $180 \mathrm{~m}^{2}$ with similar proportions of width to depth as the successful ones. The height to apex of the halls followed a similar pattern as the hall floor area, with the tallest apexes recorded in the less successful halls. This suggests that the communities were once flourishing to have supported a hall of such a size but this community has diminished and can no longer maintain or use such a large building deepening the community deterioration. The

\footnotetext{
${ }^{21}$ Median has been used in the analysis of this data, as there were some large extremities present in the data collected making the use of the average not reflective of the true spread of data.
} 
exception to this is the Maungakaramea Memorial and Ruatangata

District Halls. These two have hall areas of $360 \mathrm{~m}^{2}$ and $240 \mathrm{~m}^{2}$

respectively, and yet are continuing to succeed possibly more linked

to their central placement in their communities and annexation to other community-orientated facilities outweighing the stress of maintenance for large buildings. These halls are also in densely populated rural communities in comparison to the others.

The forms of the most successful halls were simple with a legible layout and entrance. Those of complicated amalgamated form were not well maintained. The most common form was the gable-end, particularly for the body of the hall. The body of the hall appeared to be the original building of many halls with the kitchen and toilet blocks attached. The articulation of the entrance also proved to be a key determinant in the design of the successful halls. Entrance articulation provided a welcoming signal and a clear indication of public use. Roof pitch of all the halls surveyed ranged between 20$40^{\circ}$ slope. $20^{\circ}$ slope was only present on the two newest halls of Ruatangata District and Waiotira Halls marking a change in the traditional form and aesthetic most likely attributed to the advances in materials and construction technology.
Analysis of the halls highlighted key variables and determinants for community acceptance of such facilities as listed below:

1. Central site in community, preferably on a prominent highly visible section with connection to the main road - site and building to be community-owned

2. Easily recognizable and simple form of building, bulk and layout

3. Articulated entrance to hall facing the main street and most prominent view from community

4. Off street car parking with safe roadside overflow

5. Sign visible from street

6. Easily maintainable building and grounds

7. Easy care landscape

8. Durable materials

9. Multi-functional spaces that can accommodate different configurations

10. Future proof - extension in later life

11. Incorporate passive design principles to reduce need for mechanical devices - these may get vandalized or not be installed/maintained 
These are features of what can be considered good rural community facility design. They are principles, which help the community

residents to relate to the building and to associate the building as

belonging in the environment. A sense of ownership and a

willingness to accept this ownership help the residents to feel responsibility for and take care of the building. By making this task for the resident as easy as possible for them to do and with a

building that they accept, encourages support and enables the cultivation of community. 
5.0 Research Conclusions: 
Architecture serves as an enabler for community by encouraging community building. The cultivation of community in the rural context is strongly linked to architectural theories that stem from the sociological theories of community. As there was found to be a lack of direct information regarding the rural context in these theories, empirical research has verified the reviewed determinants for community to apply in the rural context of Northland, New Zealand. This thesis has focussed its empirical research on the factors of deprivation, density and development, services and employment opportunities, rural vernacular architecture and community hall typology to establish what qualities quantify a successful community and how these can inform communityenhancing architecture. The author acknowledges that there are other factors associated with the design of successful rural communities that have not been explored in this thesis.

\section{Deprivation}

The deprivation index study highlighted the socioeconomic factors surrounding the sample communities that were of most influence on community. In Titoki, where there is a very traditional family structure and what appears to be easily accessible technology, community rejuvenation is likely through opportunities in the community to activate the residents. As this community has a higher deprivation score, and with the literature suggesting residents in deprived areas are more concerned with areas of health and finances than shared time-consuming community programmes, it is in the health and service area that stimulus for community interaction will be most successful. This finding in the deprivation literature concurs with the interview findings of the Titoki residents.

\section{Density}

Density, in the sample group, relates to community perception. Higher density and centralization of a community generates a greater sense of community. Higher density encourages informal social interaction building social capital. Of all the communities studied, Titoki was density deficient compared to the successful rural communities. For Titoki, prevention measures are essential to avoid sprawling growth out along the road edges, which would spread the community reducing informal social interaction. An architectural intervention into Titoki would need to focus the already established community to a central node.

\section{Social Interaction Opportunities}

The empirical research shows a correlation between the concentration of services and employment opportunities within the sample rural communities and the sense of community. Social 
capital is promoted in the rural context when there are more

workplaces (second) and services/gathering places (third) central to

the community. In the sample communities, it is apparent that

gathering places are more astute at cultivating community than

work places. It is in the services and employment area that Titoki is

lacking initiative to appeal to the wider community beyond the

school.

\section{Community Acceptance}

It was found in the sociological literature that it is important for individuals to feel a sense of belonging and camaraderie with the community. For the sample communities, this common

denominator is their relationship to agriculture. The architectural

literature commented on the design of communities to be specific to their context. The analysis of the rural agricultural vernacular has provided the tangible and subsequent intangible elemental criteria for designing community architecture in this rural context.

The design of community-focussed buildings is not something that is new to the rural context. Rural community halls have a permanent place in many communities and serve to facilitate formal social interaction. Their prevalence and condition in the most successful communities suggest that they are an indicator of the communities' social wealth. Analysis of the community halls revealed many important considerations for community acceptance of their design (refer to section 4.2.3 for criteria list of community halls or section 6.1 design brief). 
6.0 Design: 
Through the empirical research findings, the rural community that appears to be in most need of an architectural intervention to help with the cultivation of community is Titoki, Northland. The design is to address the factors researched in the empirical research chapters of deprivation, density and development, social interaction opportunities, and community acceptance through the design criteria based on rural vernacular architecture and established rural community building qualities. One of the key issues is of health in rural areas and the lack of this crucial resource (Statistics New Zealand, 2005a). The high deprivation score coupled with the absence of health services in the Titoki area leads to the proposal for a health and finance facility to aide this community. This proposal was discovered through the application of sociological theories and has since been supported by independent initiatives from the community itself.

The brief proposed is that of a rural Heartland Centre and an associated community hall facility to enable community.

\section{Minimum Program Requirements}

\section{Heartland Centre Programme:}

\section{2 conference rooms}

$17 m^{2}$ each

2 medical consult and exam rooms

1 meeting space - adaptable
Staffroom
Toilets
Reception
Waiting area
Storage

minimum $15 \mathrm{~m}^{2}$

minimum $17 \mathrm{~m}^{2}$

4 unisex pans plus disabled

minimum $5.5 \mathrm{~m}^{2}$

$34 m^{2}$

Tables, chairs and cleaning

\section{Community Hall Programme:}

Hall including stage

$160 \mathrm{~m}^{2}$

Kitchen with bar facilities

Multiuse area

minimum $14 \mathrm{~m}^{2}$

minimum $36 \mathrm{~m}^{2}$

4 unisex pans plus disabled

Toilets

Storage

Tables, chairs and cleaning

Design Criteria based on empirical research:

1. Provide the community with an appropriate service

2. Increase the centralisation and density of the community

3. Cluster the community initiatives in a nodal location

\section{Vernacular Criteria:}

4. Gable and mono pitch form

5. Exposed construction

6. Protected open construction

7. Open end 
8. Large opening elements

9. Corrugated roofing iron

10. Corrugated polycarbonate light panels

11. Practical flooring materials

\section{Rural Community Hall Criteria:}

12. Central site in community, preferably on a prominent highly visible section with connection to the main road - site and building to be community-owned

13. Easily recognizable and simple form, bulk and layout
14. Articulated entrance facing the main street and most prominent view from community

15. Sign visible from street

16. Off street car parking with safe roadside overflow

17. Easily maintainable building

18. Easy care landscape

19. Durable materials

20. Multi-functional spaces for different configurations

21. Future proof

22. Minimal mechanical devices 


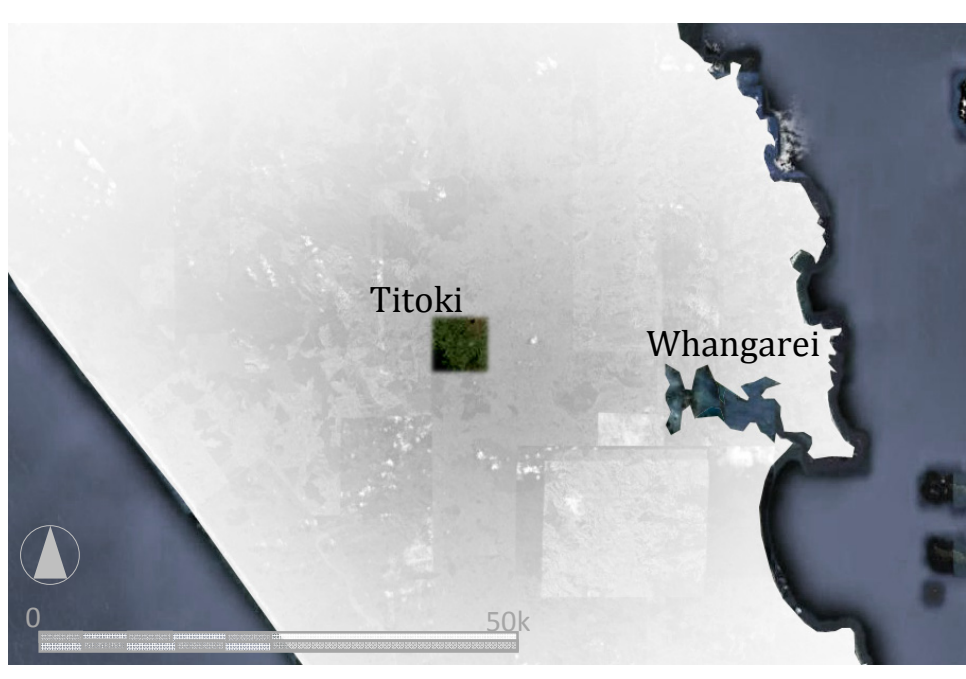

6.2a Northland Location Plan

Source: Based on (GeoEye, et al., 2010)

\section{Community}

Titoki's economy is heavily dependent on agriculture. The changes occurring in the industry are causing depopulation of established community members. This is changing the traditional community dynamics and social capital of the area.

Through empirical research, it was found that Titoki's community is waning.

The school serves many families from new-entrance to Year 13 although some families are sending their children further abroad.

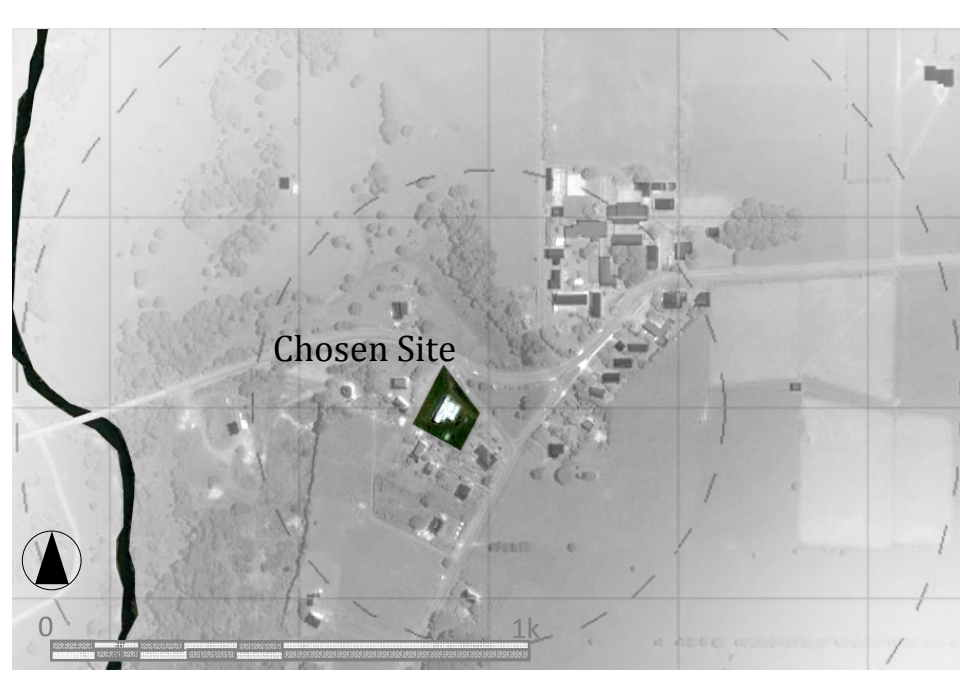

6.2b Titoki Community Plan

Source: Based on (GeoEye, et al., 2010)

All of the current Titoki community facilities are at the school, discriminating against those not involved with the facility.

The broader Mangakahia area features many long established Maori communities. The Titoki marae, Korokota, is a repository of tangata whenua ${ }^{22}$ history - analogous and entwined with the European. Historically and today, the Maori and Non-Maori of Titoki are equally valued, celebrated and respected as they have coexisted and grown up together (Centennial Committee \& McCardle, 2007).

\footnotetext{
${ }^{22}$ People of the land
} 
Gum digging and the timber industry are part of the history of the area, though the main objective was to clear land for

farming. The transitory nature of these works paved the way for the permanent farming settlement of Titoki.

\section{Environment}

Northland has a mild climate. Situated at the top of New Zealand on a relatively thin peninsula, the weather is considered subtropical (Northland District Health Board, 2010). The summers are usually hot and humid with wet mild winters. Yearly rainfall averages $1490 \mathrm{~mm}$ over 132 wet days (one third of this typically falls over the winter months) and 1973 sunshine hours with mean temperatures across the year of $15.5^{\circ}$ (National Institute of Water and Atomspheric Research, 2008). The typical summer maximum temperatures range between $22-26^{\circ}$ with night temperatures seldom dropping to $10^{\circ}$. Winter maximum temperatures range between $14-17^{\circ}$. This data suggests a warm wet environment with limited clear sky days. The prevailing wind direction is from the southwest. During summer, tropical cyclones are a possibility, bringing with them strong northeasterly winds and heavy rainfall. The 2010 summer saw Northland drought plagued, the first seen in the district for nearly 30 years.

Northland is one of the most tectonically stable areas in New Zealand (Burns \& Leathwick, 1996). The location of the Titoki community is on the southern side of the entrance to what defines the Mangakahia Valley. The surrounding land to the east is flat or rolling farm country while to the west, steeper farm and either forestry or native bush land. Titoki is elevated above the banks of the Mangakahia River. Mangakahia Road weaves its way up through the same valley as the river to Kaikohe. The Mangakahia River water level rises over its flood plains during high rainfall due to the large catchment area, which can see up $2500 \mathrm{~mm}$ of annual rain. This leaves some residents stranded during periods of high rainfall.

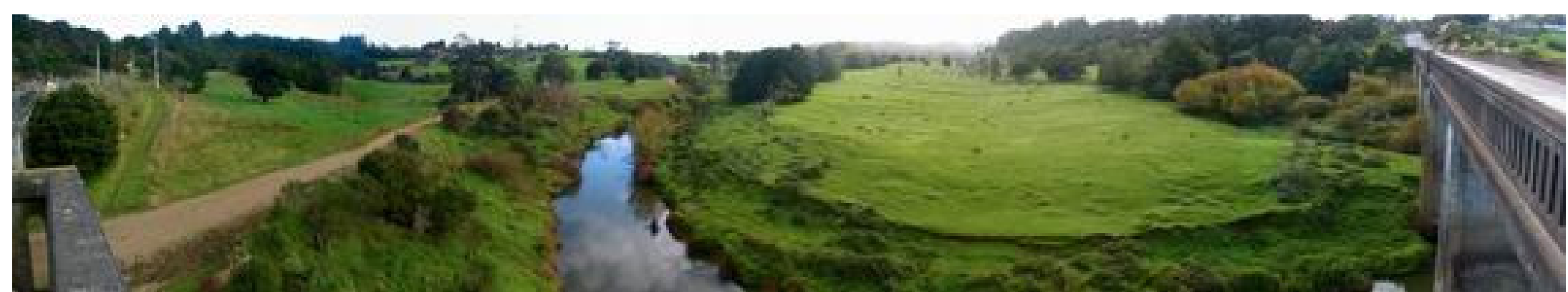




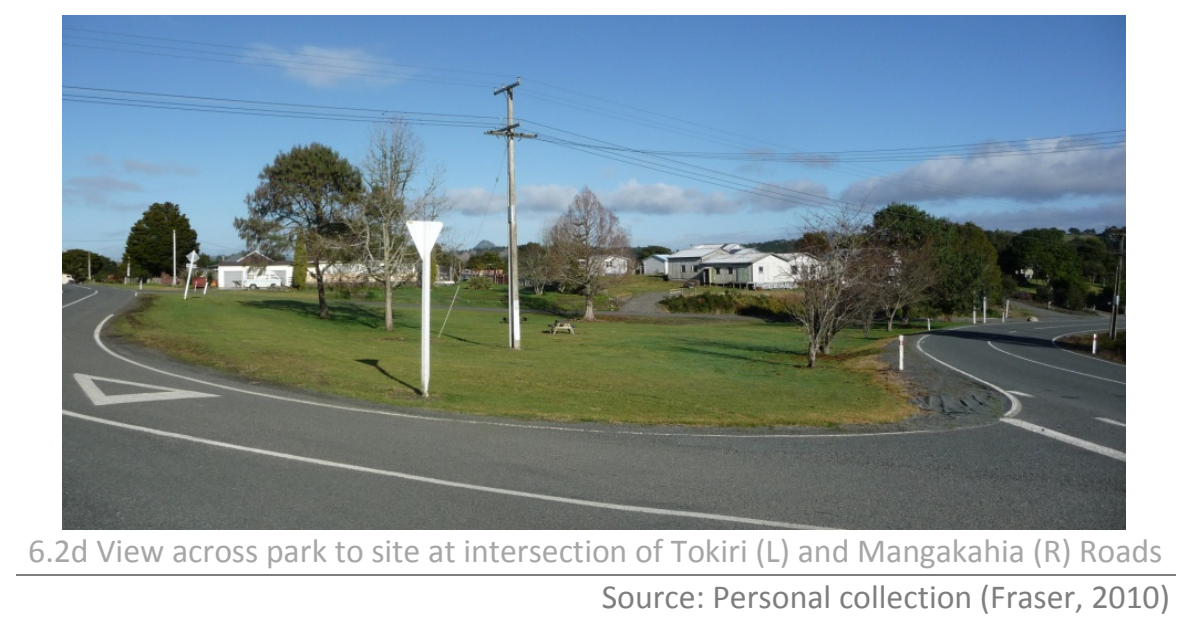

\section{Chosen Site}

The site is elevated up above the main road connecting Kaikohe to south Whangarei. For this reason, many heavy vehicles use this as an alternative route. Speed is reduced to $70 \mathrm{~km} / \mathrm{h}$ before the school and extends through the main residential area. The width of the road is an average of $10.5 \mathrm{~m}$ wide with some concrete curbing present although much of the road edge is a gravelled verge. There is a concrete footpath on the eastern roadside of Mangakahia Road for $120 \mathrm{~m}$ from the Titoki Store around and down Tokiri Road entrance (left of 6.2d frame).

The original Titoki Store flanked the site (left) of which the concrete steps remain. Behind and west is an abandoned basalt quarry. Set in the community's residential development, the site originally was farmland developed into a commercial workshop for Pat Gavin Kitchens, and is currently beehive storage.

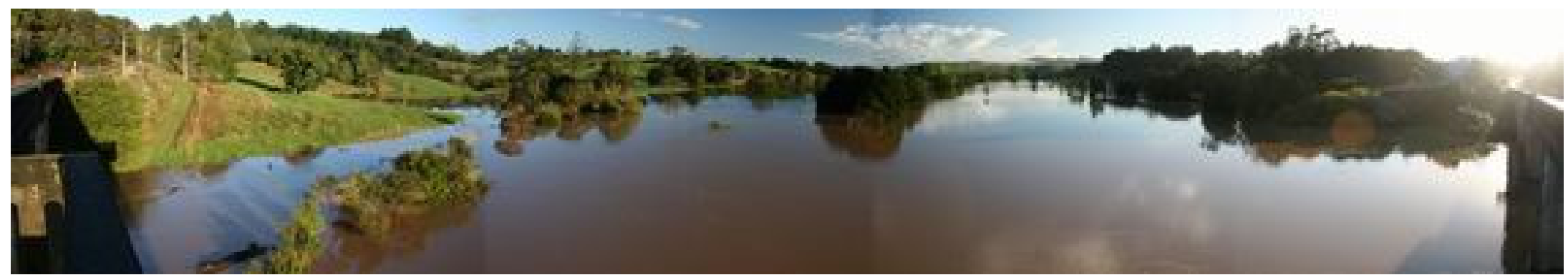

6.2e Mangakahia River at Titoki Bridge - Flood flow level 
Refer to Appendix VI for larger images.

Originally, the idea was to design a one-stop-shop for Titoki in a purpose built building for both the Heartland Centre and the community hall. This idea had boundaries to its buildability and chance of survival in a rural community. The studied rural community halls seen in 4.1 .3 show a relationship between community ownership and hall size with the level of support and maintenance community halls receive. It was found that when the community owns the hall and the size of the hall is not too large, the community feel a sense of manageable ownership of the building and will maintain the building better. When the chosen site presented itself as multiple lots, the development became a staged phasing of two separate buildings - each a separate smaller entity unto itself but through design is able to work together. This allows for the future possibility of the buildings able to be sold individually on their own lots.

The parkland is a central site in the community and appears suited to the development. Upon closer inspection and informal structural consultation, this land use would pose more barriers to the buildability of the project.

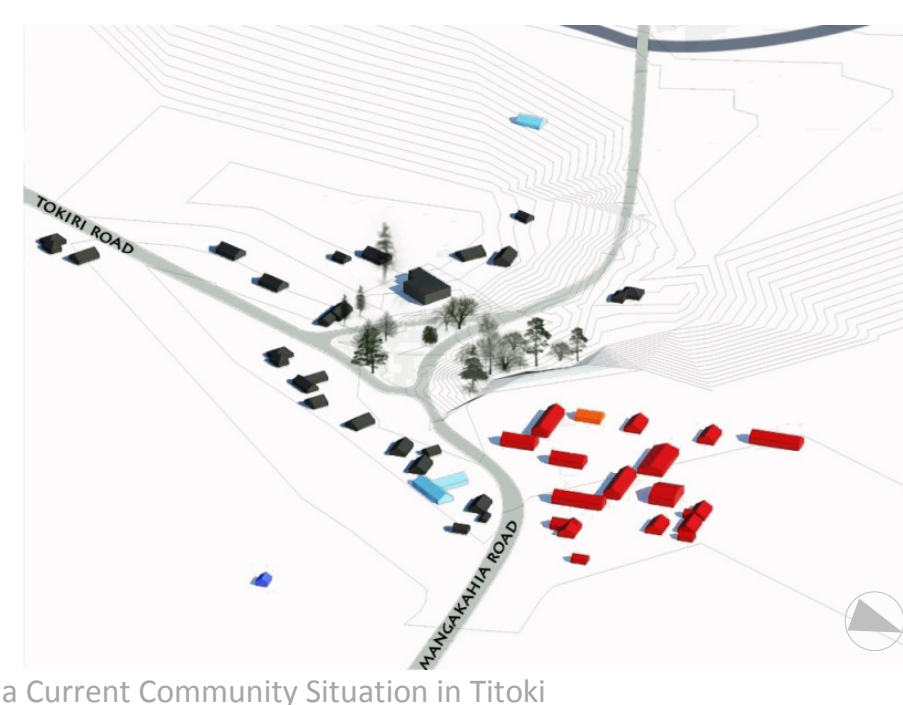

6.3a Current Community Situation in Titoki

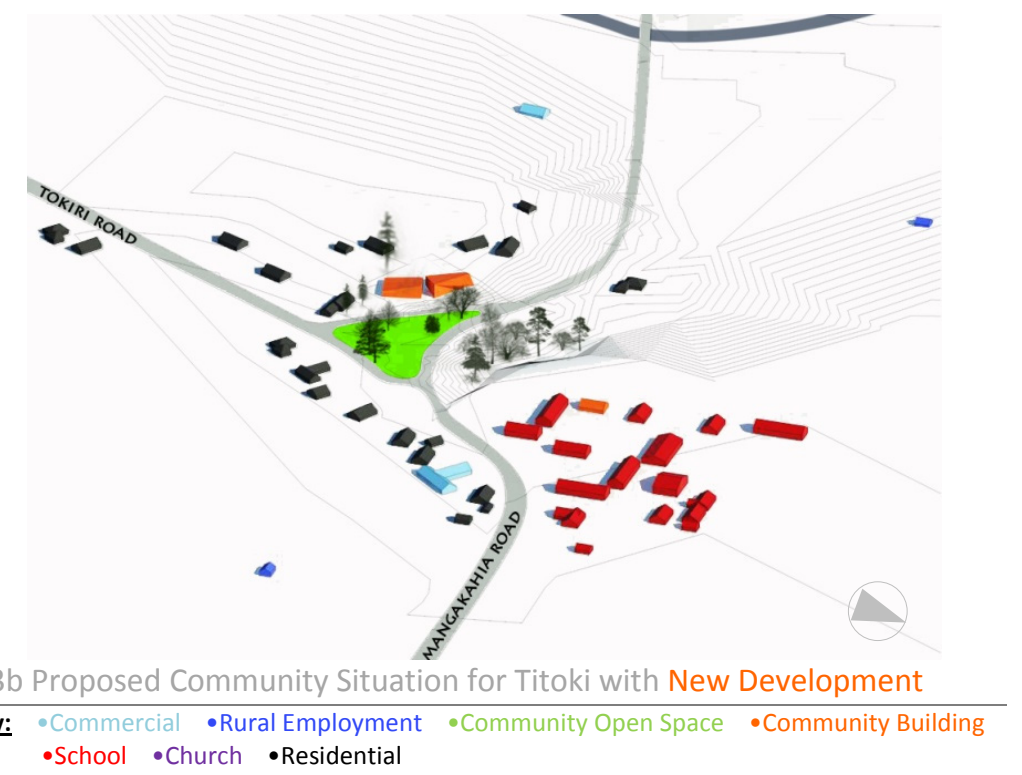




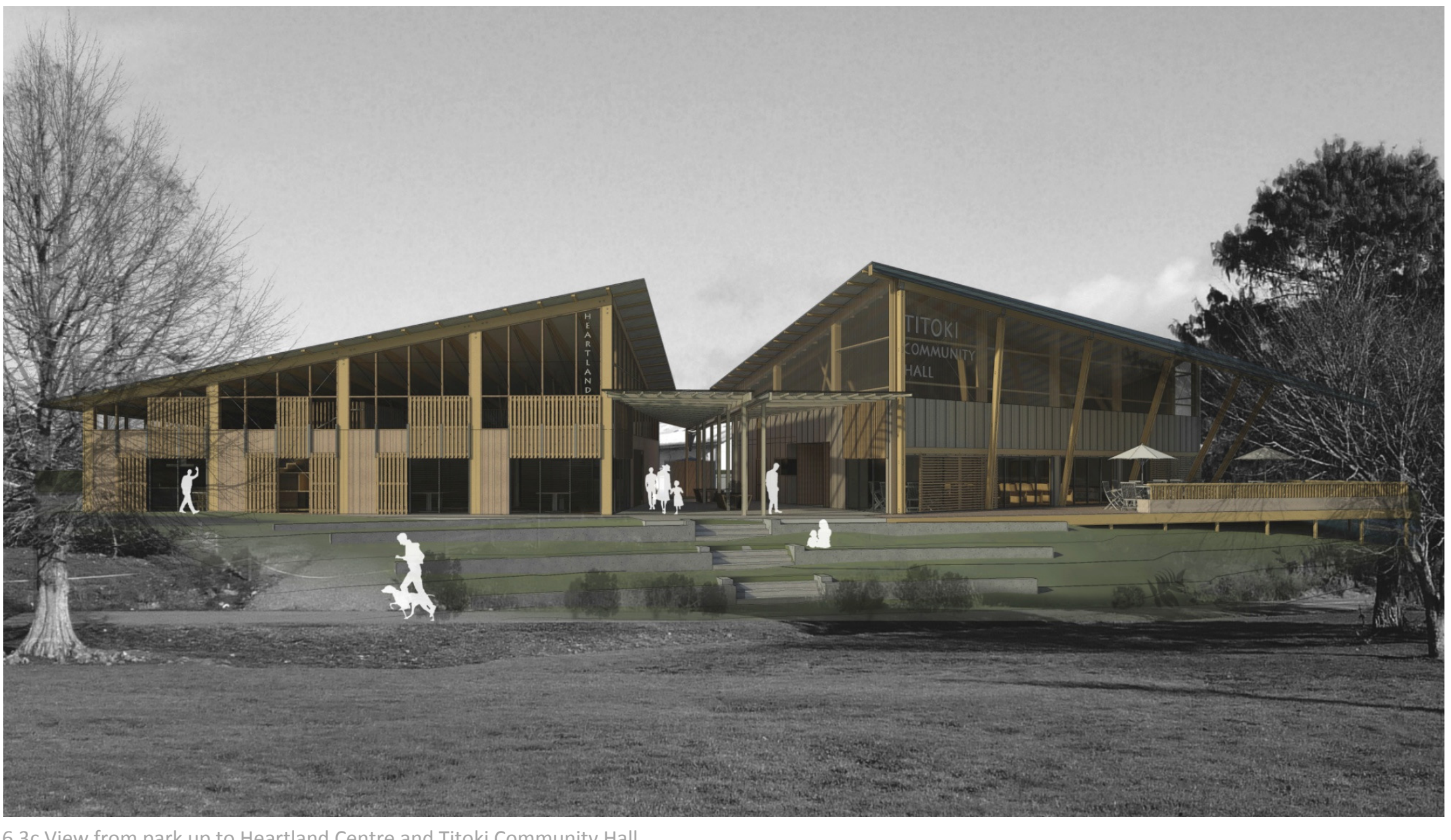

6.3c View from park up to Heartland Centre and Titoki Community Hall 
Above the park, a naturally elevated site is currently home to a dilapidated warehouse. This site overlooks the community's only true public open space and out to Mangakahia valley beyond. Its position is central to the current residential development and directly accessed off the main road over which it looks. This gives the buildings a caretaker's role in the community to watch out over the area and serves to announce its presence. The mixed-use visual surveillance that comes with linking these two programs and the site choice provides security for both the park and the development.

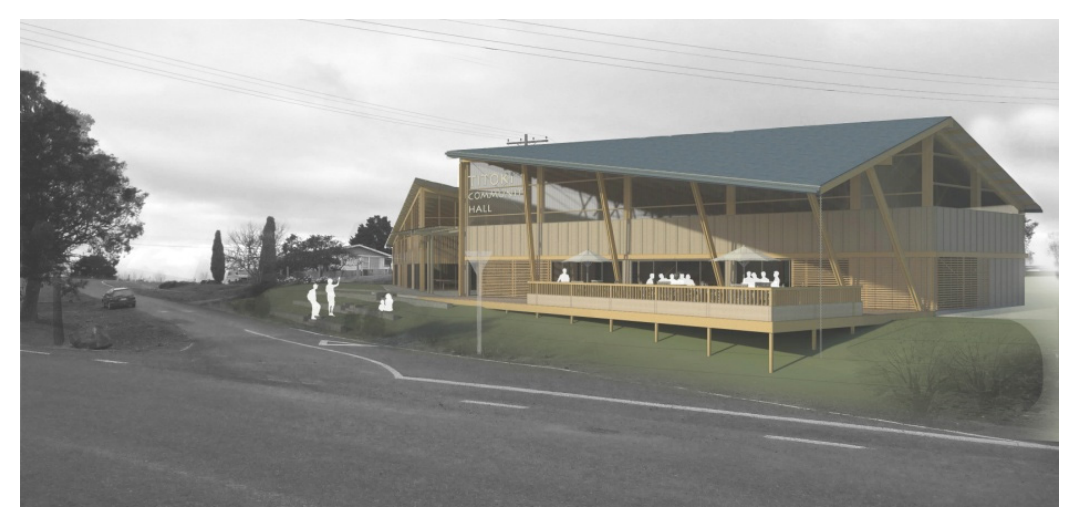

$6.3 d$ View from the North

Augmentation of the gable and mono pitch is the primary form concept (refer Appendix VI: Design, 6.1) based on these forms prevalence in the architectural vernacular. Its expression is paramount in providing the community with a spatial awareness of the distorted form. This distortion remains subtle enough for the base forms to endure while the twist occurs. The truss structure to create this twisting angle accentuates this internally.
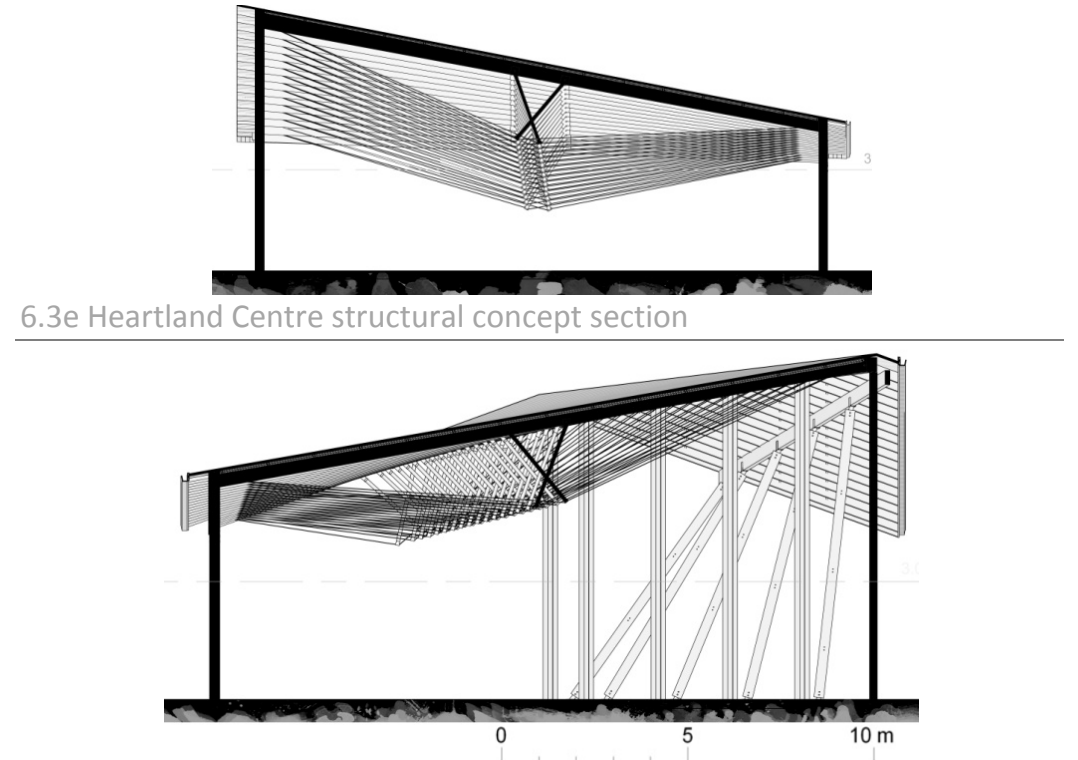

6.3f Hall structural concept section

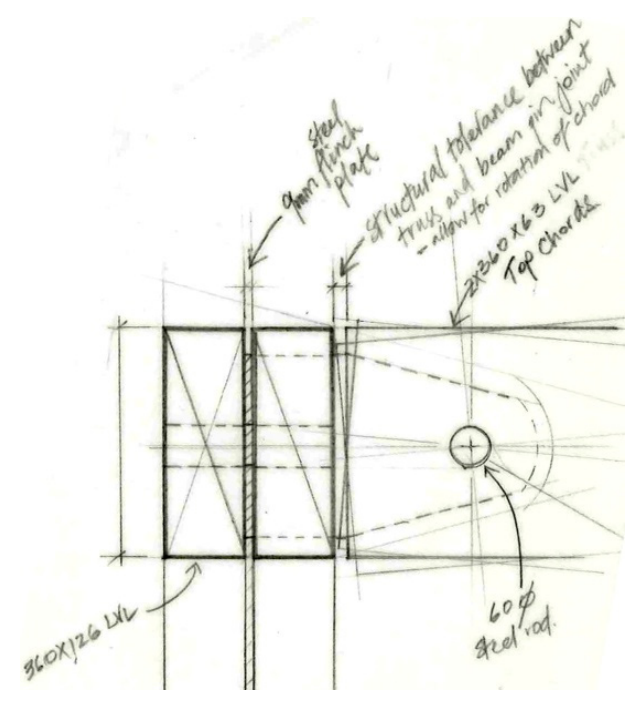

6.3g Truss end pin joint sketch detail 


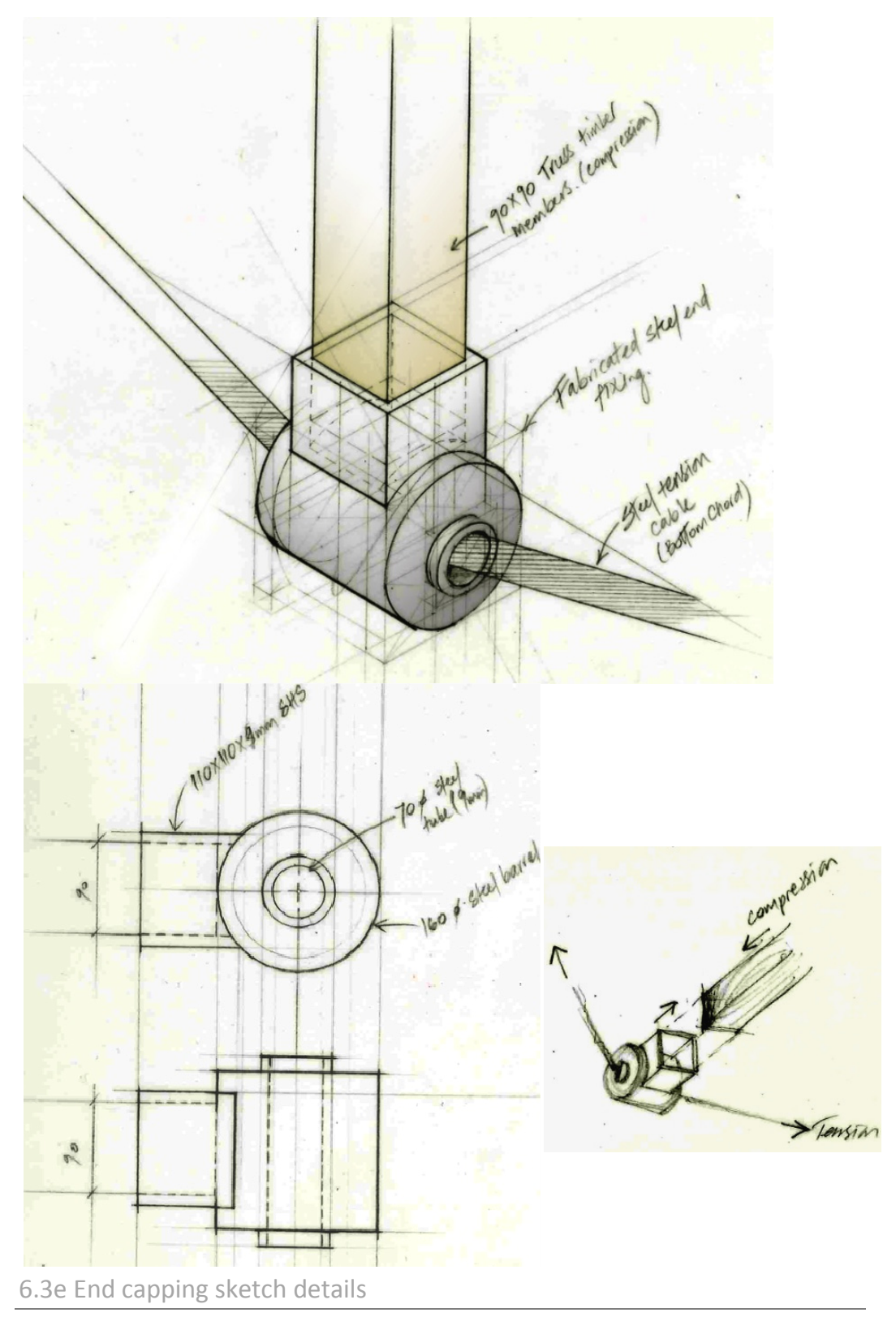

The structural system of bowstring trusses at $1200 \mathrm{~mm}$ centres protrudes down into the roof space pivoting about their top midspan point. This pivot point creates an incremental shift in all truss elements as the roofs move through the augmentation. The structure of a truss is the use of individual members working together to create a structure stronger than the individual members. This structure uses simple standardised joint techniques where possible with a steel cable to bind the system together.

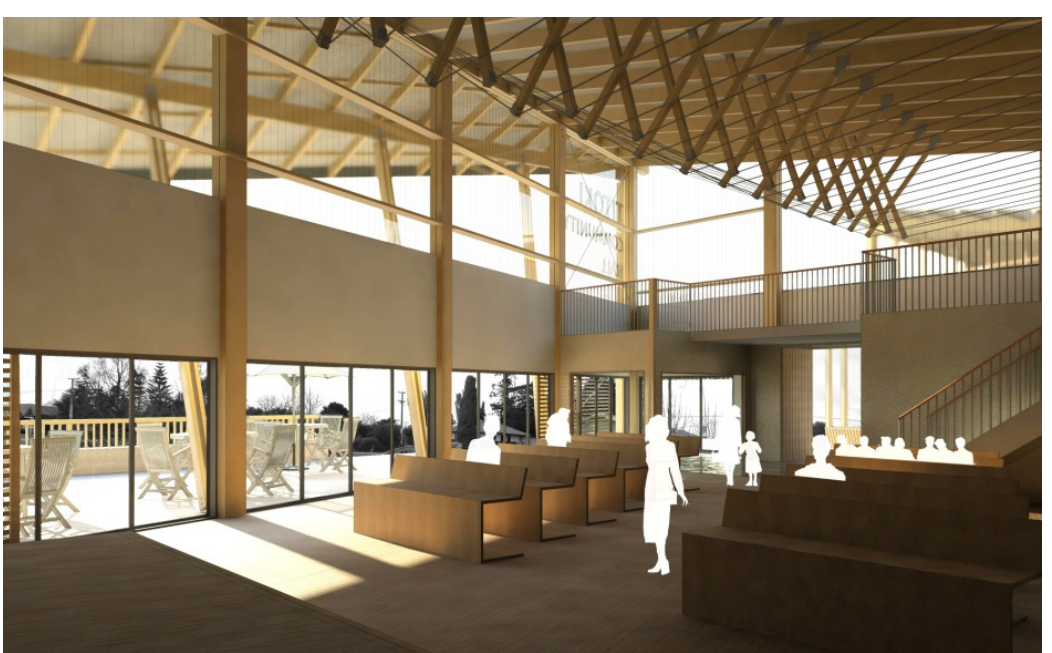

6.3f Structural expression - interior Titoki Community Hall

Metaphorically, this is the social structure of a community where the social network is strengthened by the connections within - the individuals in the community working together form a stronger community when bound together. Internal truss members rely on the tension of the bottom steel cable to hold their end caps in place. 
These capping elements mimic the technology seen in the hydraulic lifting systems of agricultural machinery.

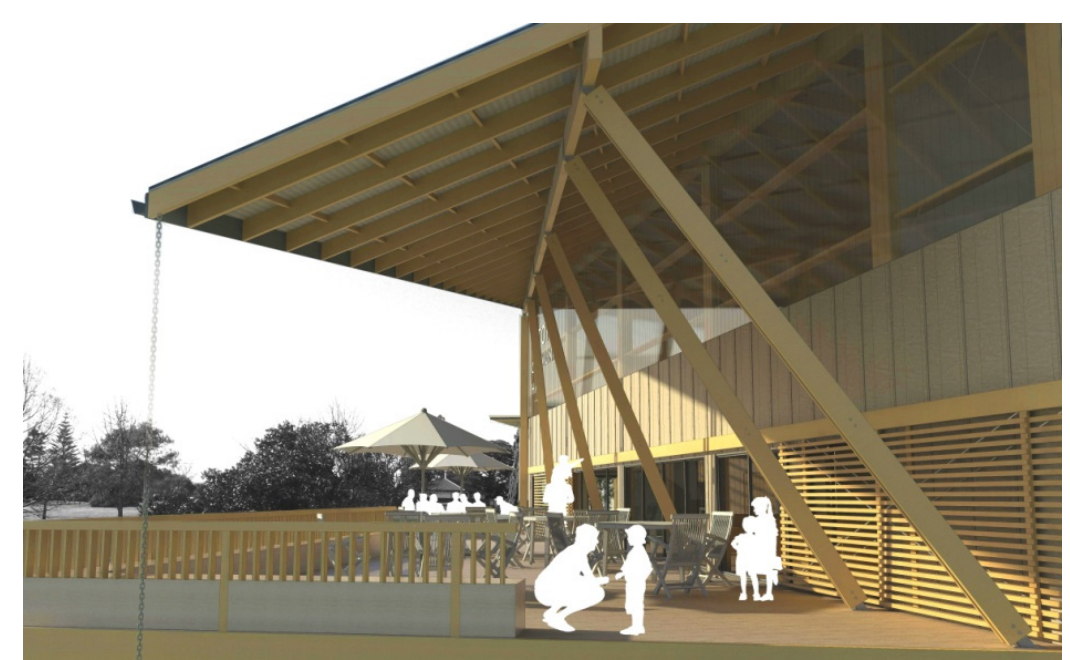

6.3g Structural expression of propping the augmented veranda

The external structure seen in the propping columns to the veranda follow this accentuation of twisting by rotating about their base connection to the mid span point of their associated veranda beam and rafter.

\section{Phase Development Proposal}

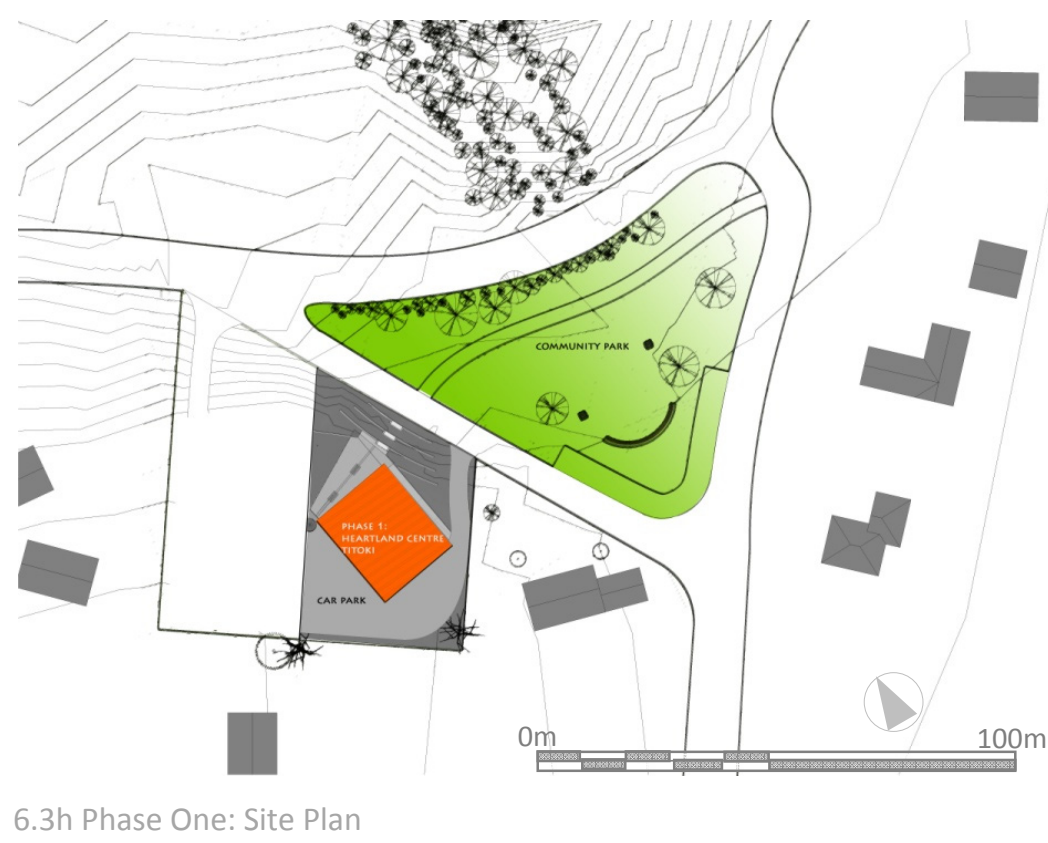

Phase One: Heartland Centre to serve the current Titoki situation

This cross-sectorial activity enables community capacity building as Casswell (2001) deems it, through the effective use of resources.

Providers of local services are viewed by the community to have key roles and become part of the community. It is for this reason, that this proposal of a Heartland Centre in Titoki be only one in a string of Heartland Centres throughout the rural context of New Zealand. The Heartland Centre will be a thread connecting the rural communities. In terms of social capital, the Heartland Centres will help bridge communities, broadening their social spheres. It will 
also provide a sense of commonality for those transient community members such as the share milkers and herd managers who travel following work placements. The program for the centre is that of hot-desk situation where the professionals are able to book the offices and use them as a local base to serve the community. The professionals proposed to use this facility are doctors and medical professionals in the medical consult rooms; and accountants,

lawyers, agricultural advisors, rural counsellors in the conference offices. This programming lends itself towards having permanent setups for the medical offices and more flexible spaces for the conference offices ${ }^{23}$. The flexible nature of conference offices allows these to open up and serve as a communal gathering space while still fulfilling their primary role as offices - the role they may revert to upon completion of phase two.

\footnotetext{
${ }^{23}$ Medical offices require higher levels of hygiene and specialist knowledge of equipment and utensils opposed to the standard data points and table set up in the conference offices
}

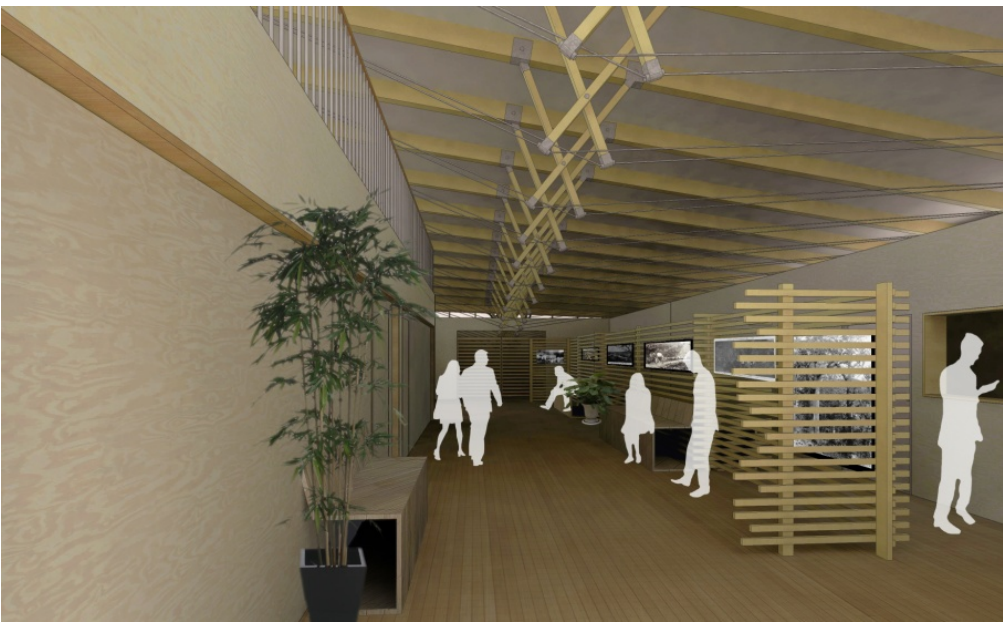

6.3i Heartland Centre as professionals' offices

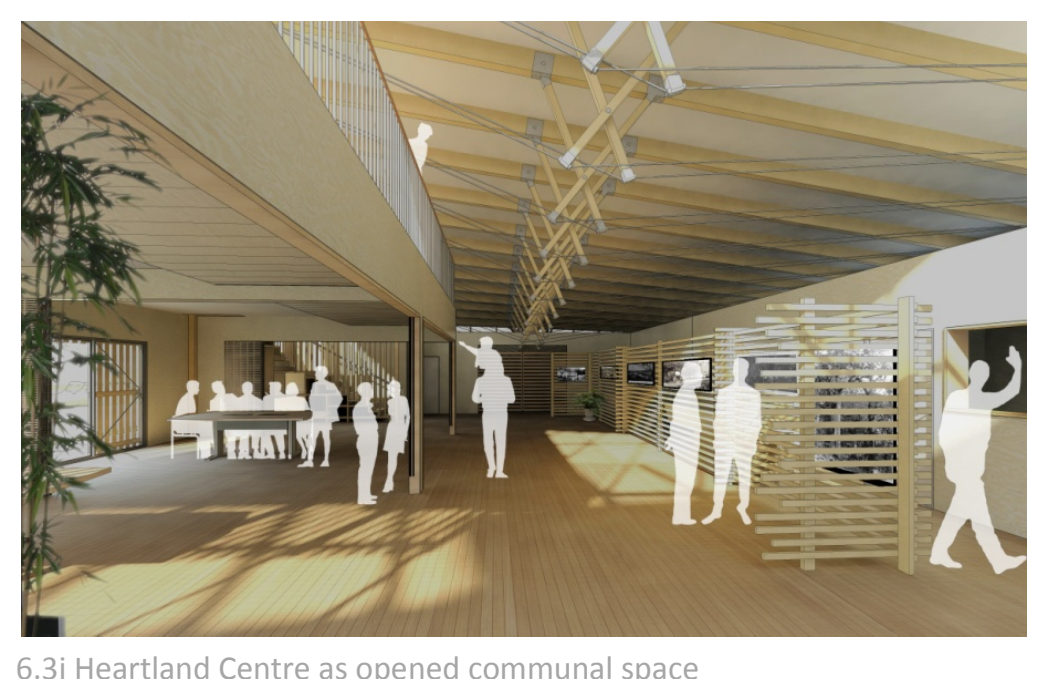

6.3j Heartland Centre as opened communal space 
The Heartland Centre's communal gathering space is for meetings or social functions for the members of the community to book. It is for this reason that the associated facilities such as the storeroom, kitchen and toilet/shower must accommodate for the hosting of these events (up to 100 people comfortably with a provisional allowance of 200). As the site is at the entrance to the Mangakahia Valley, the centre will also need to serve the wider community in performing the civic duty of Civil Defence Centre particularly in times of flooding, as the valley is prone to.

Included in the Heartland Centre is a history wall that defines the edge of the communal space. This freestanding wall snakes its way around the outskirts of the communal setting telling the story of the area as it has developed $-\mathrm{a}$ time line of events. This wall provides a line to form a boundary to the communal space by the subtle means of a material change inlaid into the flooring. The flooring inlay continues the timeline around to the stairs - the termination of the timeline in the showcase of the community trophy cabinet where both current and past successes are celebrated. This library of memories for the community has reference to the tradition of memorial halls established in the wake of disaster as a celebration of the community.

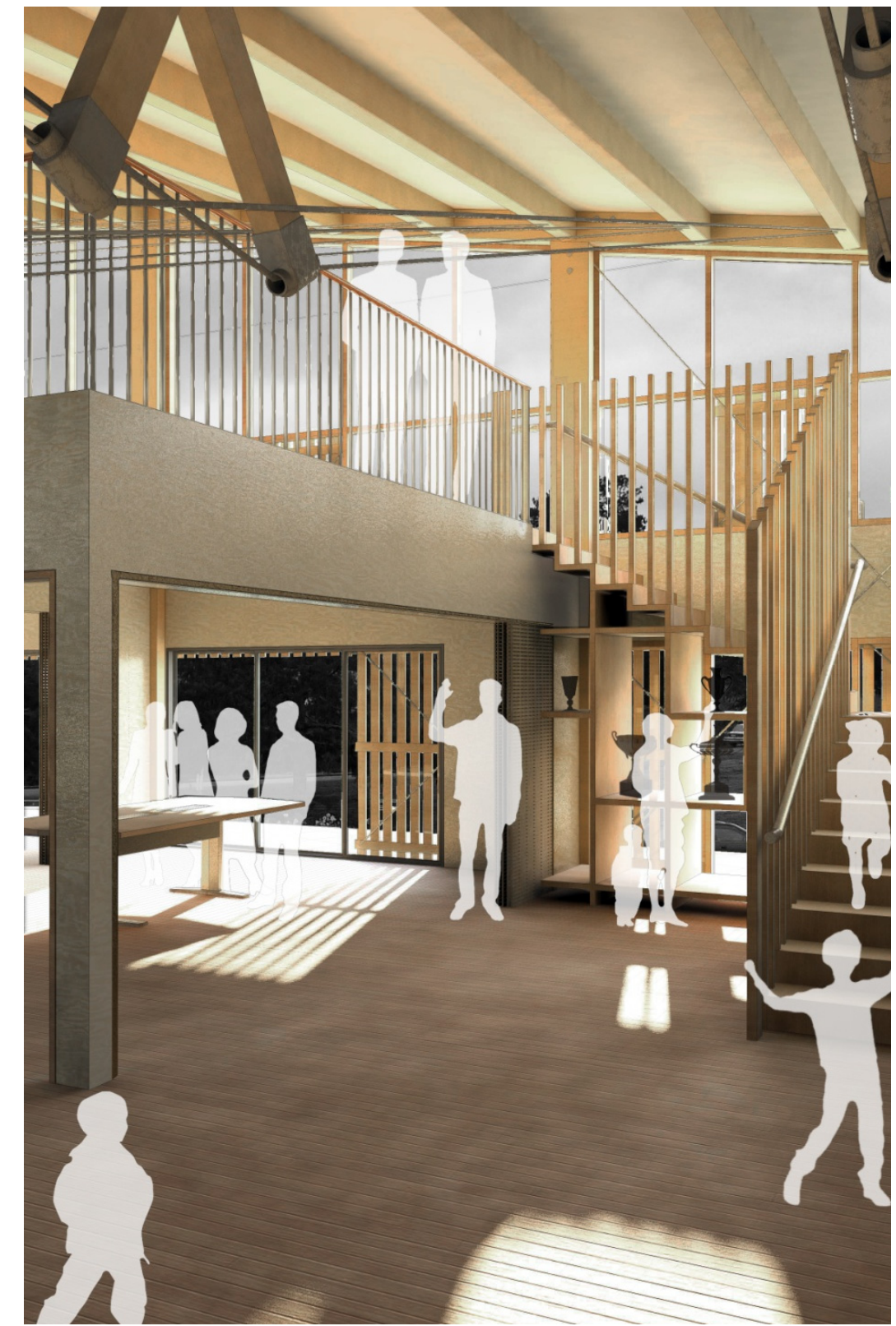




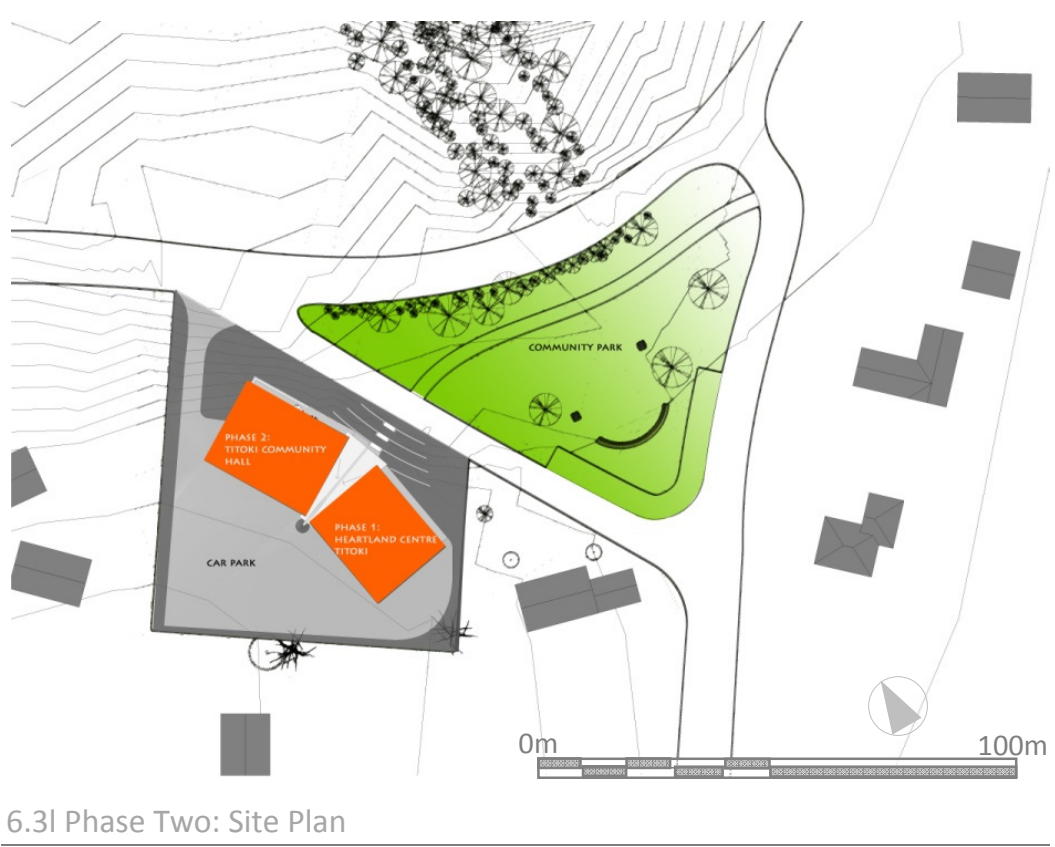

Phase Two: Titoki Community Hall for future Titoki Community

As the Titoki community grows, the demand will come for a larger community gathering space and for the Heartland Centre to dedicate itself to the conference office set up full time. This calls for a community hall to meet the demand placed on it by the growing community. The current situation of sharing the gym space in the school excludes those who feel unwelcome on the school and may cause a conflict of interest in the types and timing of events held. The concept for this hall is to work with the design of the Heartland Centre and complete the picture (refer to 6.3s). This part of the development is to speak of the community individually when the centre reverts to the function of commercial offices venture. This is why the hall's design is one that while complimenting the centre, displays the augmentation of the gable when viewed as an individual built form. The hall is designed to host $150-180$ people comfortably and has provisional allowance to accommodate over 200.

Upon phase two completion, those who arrive via a vehicle will need to drive past the complex before turning to enter the site and parking at the rear. This will orientate them to the buildings entrances and allow them the chance to appreciate the complete augmented gable form.

It is essential for communal buildings to have recognisable articulated entrances. The use of a lower level canopy at a human scale and centrally placed in the front gable, signals a protected entrance. The vehicular users' entrance is secondary to the pedestrian with their entrance originating from the "back-of-house". The Heartland Centre is turned on site to open the courtyard space up out to the community and the view over the park and out across the valley. This turn in the complex buildings opens up the entrances to the community, welcoming the community. 


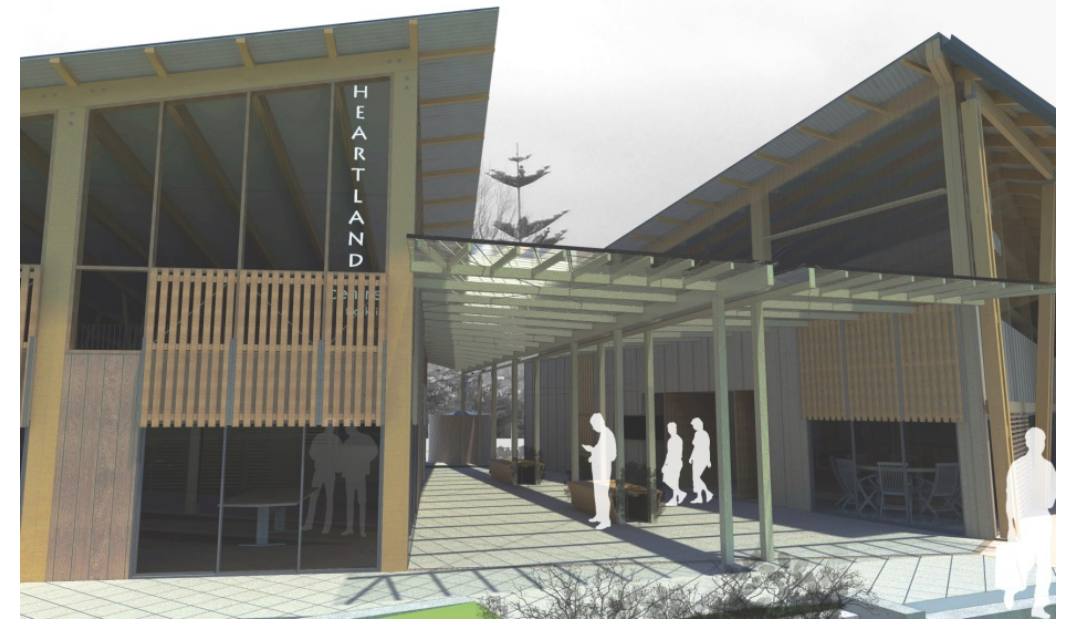

6.3m Entrance Canopy - pedestrian user

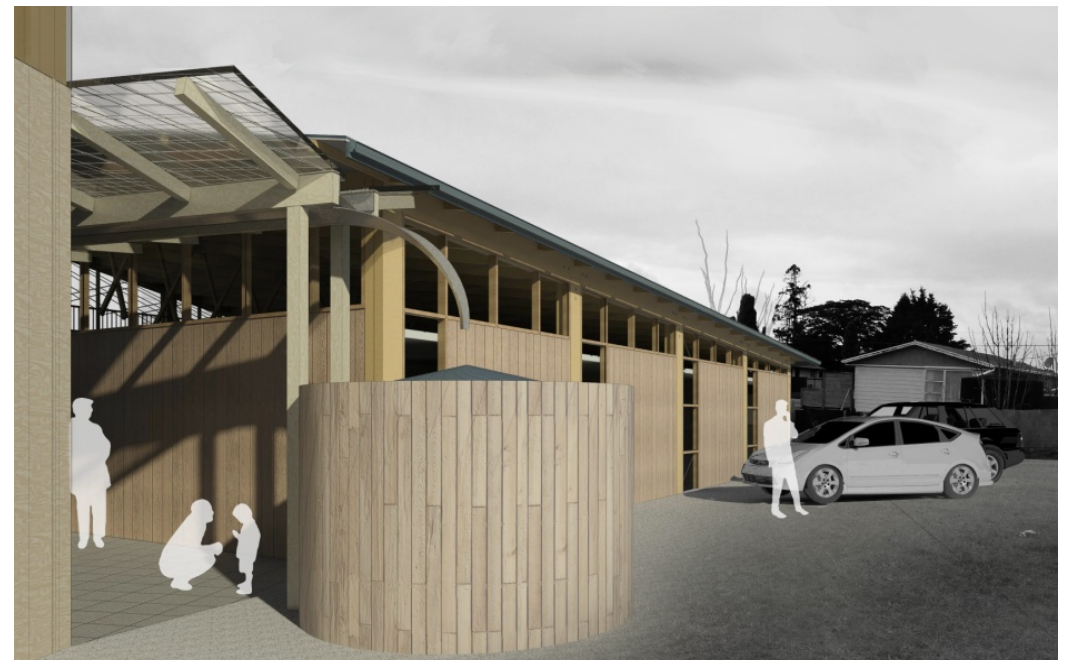

6.3n Entrance Canopy - vehicle user

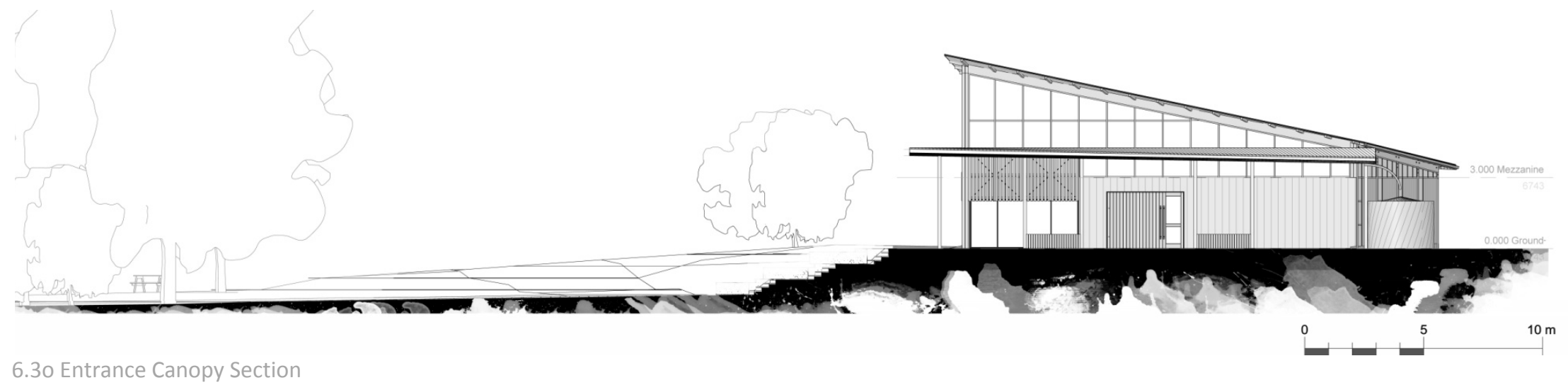

This also opens the Heartland Centre to the north while still having the shading from the deep overhangs and lower level entrance canopy. The v-shaped entrance courtyard created plays with the pedestrian's perspective view and forces focus onto the furthermost point culminating in a featured water tank - a practical necessity in this rural community. Beyond this focal point is the car park and back-of-house. The vehicular user's insulated view is reversed back out from this single point out over the community. 


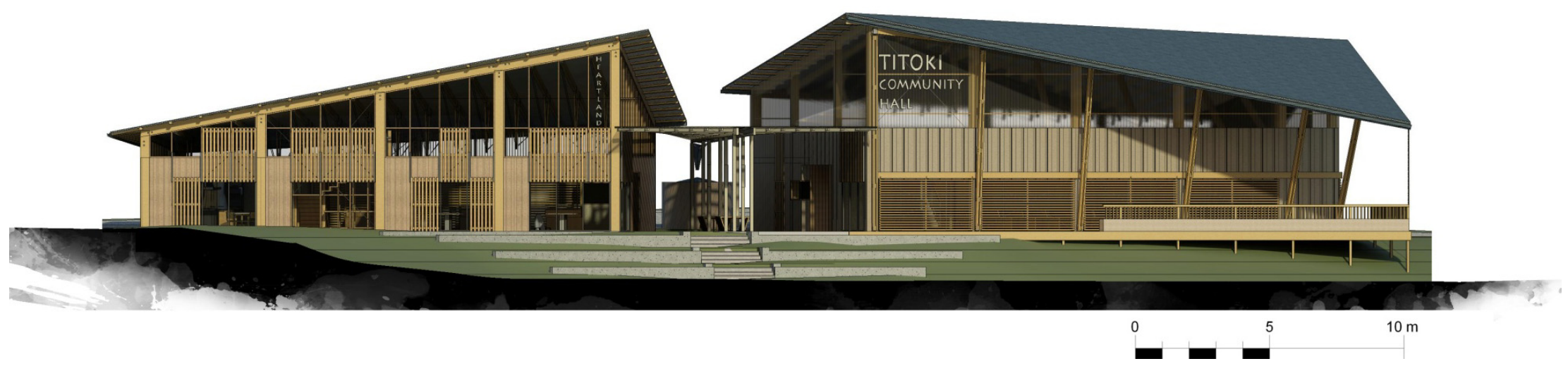

6.3p Front (Northeast) Elevation

Phase One and Two are intended to read to the user as a single built form. The differences between the two are subtle in their translation to architecture. Besides the differences in form, the material palettes for the two are similar and use similar techniques but are not quite the same. The external wall cladding chosen for the Heartland Centre of vertical ship lapped macrocarpa will require a higher level of craftsmanship to install and the maintenance is greater than that of the vertical board and batten plywood system seen on the hall. Internally the wall claddings for both are a whitewashed plywood finish. Both use vanished timber floors in the communal spaces and polished concrete to the service/wet areas and permanent use facilities.

The programming of these communal gathering spaces is not explicitly set; they may host any number of activities from church services, weddings, political forums, exhibitions to community meetings, knitting groups even tourist ventures may develop. The adaptable design put forward is a concept to test multi-functioning spatial design. 

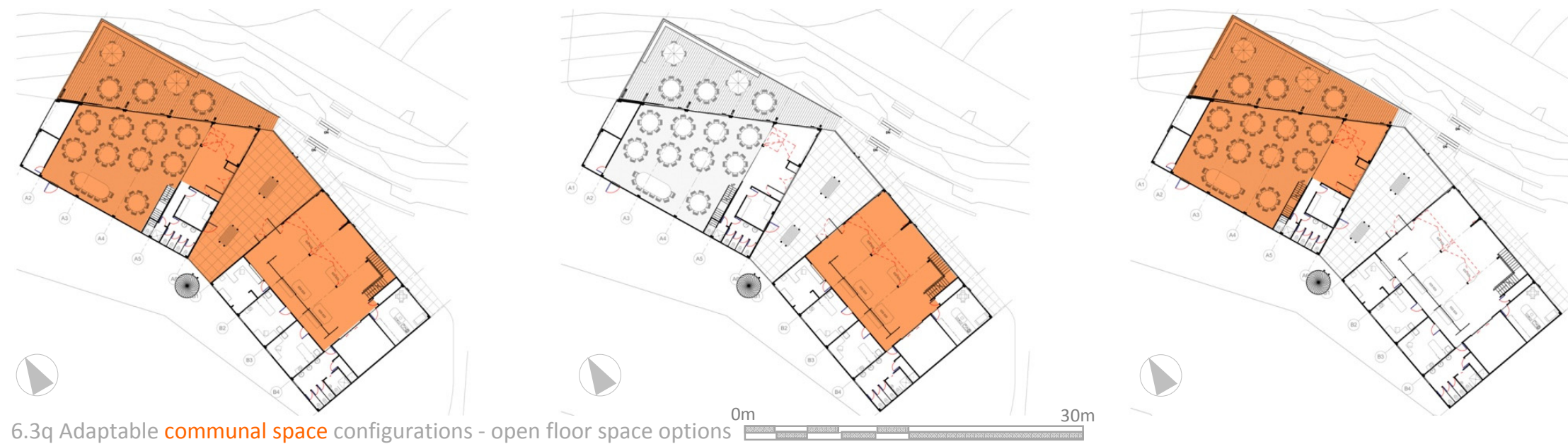

6.3q Adaptable communal space configurations - open floor space options
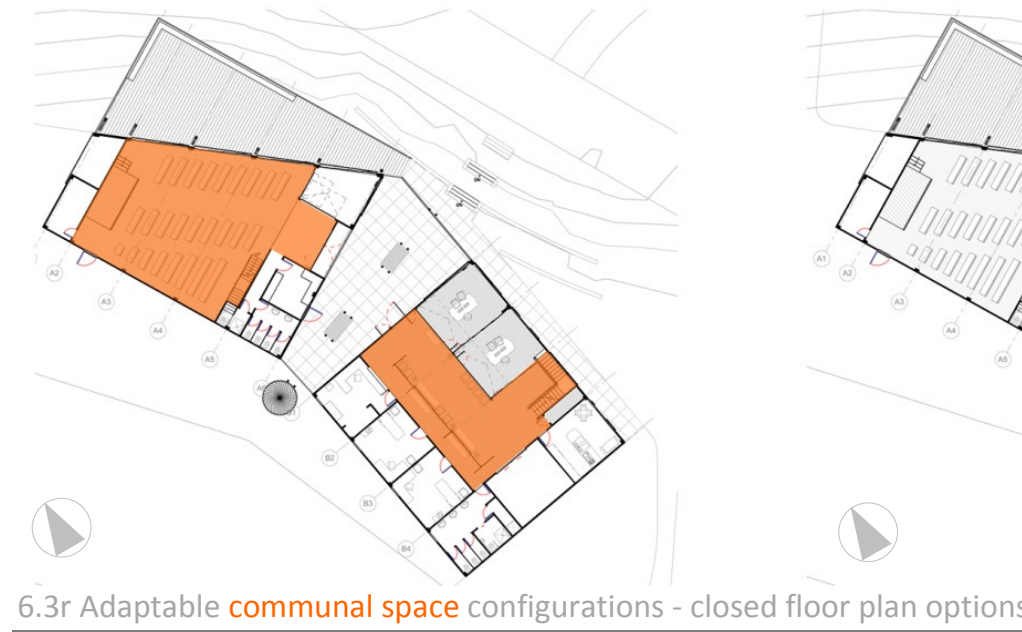

With the planning, (refer to Appendix VI for detailed plans),

attention of the user is focused out on the surrounding community

by the long northernmost walls opening up to overlook the park.

The southernmost walls are then as solid as functionally possible to ground the form back against the car park. This is the reverse of the

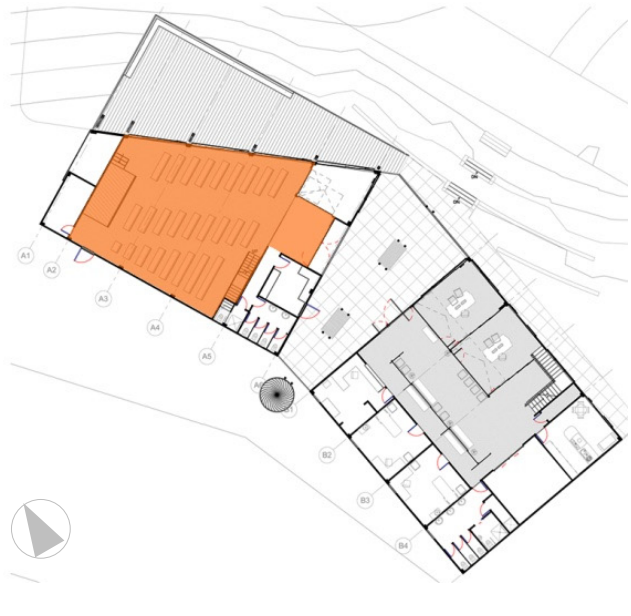

$30 \mathrm{~m}$ traditional community hall layout where the hall area has a stagedirected internalised focus. This stage-focus set up may also be achieved if desired by closing this northern wall by way of external timber slat sliders. These sliders also aide the shading of this façade particularly during the winter months where they can be arranged 
to prevent glare in the hall but still allow access out into the covered outdoor space.

The roof structure is highlighted by clerestories to lift the roof up above the wall structure giving it a floating independent appearance. Like the wall cladding systems, the clerestories employ different material techniques to express the level of refinement.
The hall uses the clear corrugated polycarbonate sheeting with a horizontal timber girt system between the vertical column systems.

The Heartland Centre employs a timber glazing system with vertical timber mullions set at the $1200 \mathrm{~mm}$ intervals. This subtle change in the overall appearance of the two buildings provides a distinction to each as an individual yet has a common goal.

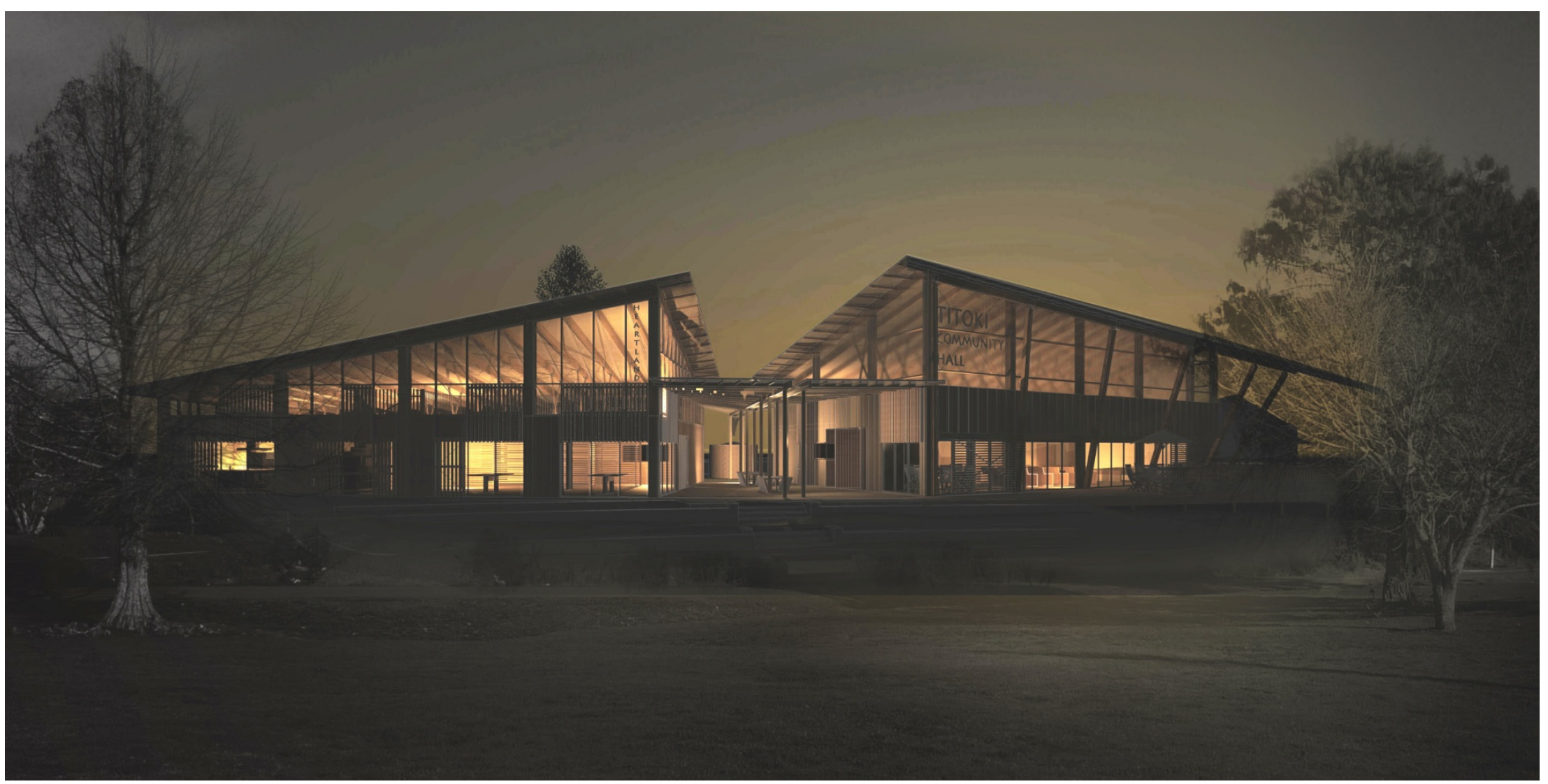


Before critiquing the design concepts and criteria outlined in the brief, mention must first be made of the limitations to the design process. The design criterion was devised based on the conclusions of the empirical research. This research was undertaken as a test of the sociological and architectural theories of community recognised in the literary works on the rural context. The criteria thus excludes some of the issues surrounding designing for a community such as ethnicity, community involvement in the design process and the exploration of precedential contemporary community centre design. The five base theories chosen to investigate in this thesis were those that were well covered and featured in the scope of the reviewed literature. Another limitation, which may have skewed the design criteria, is the manner of collecting the community perception data. Had the interviews been in conjunction with a public forum, the results may have varied.

\section{Program Requirements}

The minimum program space requirements based on the community hall typology and government regulations were all met with some going beyond due to the shape of usable floor space and the cross programming. This is most evident in the Heartland Centre where the waiting, circulation and conference offices spaces open up to create a larger communal space. This type of cross programming space may lead to better spatial experiences (had they been kept to the required, the space may not have been user friendly with interrupting columns) but may not be true to the expense incurred to create such functioning spaces. The employment of nonstandard building techniques also requires a higher build cost such as the internal tilt-up walls.

\section{Design Criteria}

The design of the Heartland Centre was intended not to demean the community by labelling them "deprived". The required health and finance services in Titoki pitched as a franchise across multiple communities will help the community to accept the nature as "a hand up, not a hand out". The design of the rooms for the centre are industry standard to enable the professionals who serve the communities to have adequate support and knowledge of the arrangements. This conventional design negates hostility the community may associate with a local service being substandard to the urban services.

The design proposal in response to increased density centralisation and as a node of community opportunities is but a stepping-stone in the final resolution of these ideas. A master plan further into the 
future would show how the Heartland Centre and community hall could start to be the revitalisation of Titoki. Intensification of

density through the means of commercial, residential, industrial and aged care facilities can be brought into the redevelopment. Agedcare is more viable after the Heartland Centre is in place as health and communal spaces are a concern with retirement villages. By making the Heartland Centre the first move, the community would feel as though it is everyone's.

\section{Vernacular Criteria}

Community acceptance is fundamental when designing a facility for a community group. Basing the design around the gable and mono pitch form together has created something thought provoking from the ordinary - a recognisable shape that is unique. This parameter placed on the design narrowed the design scope concentrating efforts on the roof design. This concentration on the roof reduced efforts on other design facets. The exposure of the timber construction offsets the uniqueness of the roof forms; clerestories wrapping around both buildings emphasise where the effort has been placed; intricate structural systems left exposed express a rawness and delicateness seen in the vernacular open construction protected by the overhanging eaves.
The three-sided, open-end vernacular criteria in agricultural buildings are so for easy access. Translating this into a different program and keeping it functional called for a less literal layout and the creation of the illusion and possibility for this to occur. It is created by large opening elements along the northern walls - like the openings seen mostly in storage sheds. Their opening action did place restriction on the design as conflicts arose with other design concepts. The layout for a community centre and hall is the reverse of the inward focussed halls researched. In the layout used, the community is focussed out over what makes them who they are not necessarily a place of private reflection seen in memorial halls.

The materials palette outlined for the vernacular are all reasonably cheap alternatives and readily available in the area. This has a sustainable quality while still covering a functional range of materials. Basing the design concept materials on these reflects this and yet the subtle introduction of other technologies and materials allows the vernacular translation to be contemporary.

\section{Rural Community Hall Criteria}

In terms of the hall criteria, the whole complex needs to be analysed against this, as they are both community buildings. The site choice, building form and entrance are justified in their development. The site is highly visible and prominent with a recognisable and 
understandable layout. The entrance articulation may benefit from a signalling beacon. This could be the water tank becoming a water tower, grounding the position in the community. This has likenesses to clock towers and memorial statues as a civic focus in urban plazas. The community may find this condescending. The hall and centre signs, particularly with them backlit on the clerestories, and the buildings bulk in the community is a start.

The car parking is off street, and the grounds and buildings maintainable by the community by way of materials and simple design. The car parking's position on site is the opposite of the traditional community hall where the car parking was at the front entrance. This privileges the vehicle and was not practical on this site to maintain the prominent position - the building would be obscured by the rise.
The building materials are durable and chosen for their variegated appearance. This involves less maintenance for the community as they are inherently not perfect nor will vandals find them suitable to graffiti.

The floor plans generalised spatial arrangement and adaptable layout of walls and privacy layers ensures the building for mixed use, accommodating multiple configurations. This future proofs the building for the short term. By having a phased plan and separate ventures able to be either amalgamated or dissolved in later life, the complex is ensured a little longer life in the community.

The criteria outlined in the brief - derived from the empirical research, did hamper exploration into other fields of conceptual thinking. The design was narrowed and focused to the agricultural identity of the community as a whole as outlined by Statistics New Zealand's definition of a rural area with low urban influence. 
7.0 Conclusion: 
Communities in the rural context are a seemingly forgotten frontier of architecture. New Zealand's economy is heavily dependent on the agricultural sector associated with the rural context and is a renowned feature of New Zealand's landscape. The community who form the agricultural sector are predominantly based in the rural settings of small settlements scattered throughout the countryside. It is here in the small rurally isolated communities where the future of rural New Zealand can be cultivated through the community's architecture.

This thesis poses the research aim to investigate how architecture in the New Zealand rural context can cultivate a greater sense of community through the empirical research of existing rural communities. It focuses on the three sample communities outside of Whangarei on the Northland peninsula. The sample communities of Titoki, Maungatapere and Maungakaramea are communities that have developed around farming and are experiencing firsthand the changes in the agricultural sector as it seeks to become more competitive on the global market. These changes are affecting the communities as agribusiness, depopulation and corporate farming threaten the established traditional rural communities.
Throughout this thesis, sociological and architectural theories of community have been explored to establish the quantifiable theoretical determinants of community. These determinants were applied to the sample communities to investigate whether they reflect rural community. As architecture serves as an enabler of community, these determinants became the criteria for design based on the theories investigated. This investigation and the diagnostic analysis used is an initial step in understanding the cultivation of community in the rural context. The process of applying the presented quantifiable sociological and architectural theories is one method for the investigation of rural communities.

\section{the Rural Context}

It was found in the literature reviewed of the rural context that rural areas of low urban influence - the sample community category - are significant in their support and contribution to New Zealand's economy. This definition of rural community is a generalised categorisation used to define many rural communities and hence is not a sole indicator of community identity. Many factors are not considered such as ethnicity or history. Research into such specific topics would broaden the scope beyond this thesis by specifying the outcomes unique to the chosen community. This research has 
provided a definition of the rural context as the identity of the collective rural New Zealand.

Productive rural communities are dependent on each other to share their knowledge in a support network. As their working environment is changing towards emphasis on increased profit margins, this web is being strained. Technology and agribusiness are changing the community dynamics of New Zealand's rural context. The traditional rural way of life is transforming under pressure from the agricultural industry. As this change is coming from agriculture, other communities dependent on agriculture will also be experiencing the shift. For the changes in agriculture to have such an effect on the community, it is apparent that this must be one of the key determinants in the rural context.

\section{Community}

The sociological and architectural literature reviewed concerning community is general and many of the theories are not easily measureable. The key quantifiable theories for determinants of community wealth found were deprivation, density and development, and social interaction opportunities. These, in conjunction with notions of belonging and community acceptance through vernacular help aide the cultivation of community through architecture.
Many of the discussed theories of community building made no direct mention of the rural context throughout the literature surveyed. The empirical research undertaken externally applied the quantifiable sociological and architectural theories to the rural context along with the internal perceptions of the rural community members to determine if such theories do quantify community in the rural context.

\section{Empirical Research}

Through the external application of deprivation, density and development, and social interaction opportunity theories on the rural sample communities it was found that they depicted variance in the levels of community. The internal process of evaluating the community perceptions through interviews confirmed the variation in the external evaluation as accurate determinants of community. This proves that the deprivation, density and development, and social interaction opportunity theories are applicable to the analysis of community in the rural context. Through this first step of empirical research, it was determined that the Titoki community was the community most in need of an architectural enabler for community building. An interesting finding from this process of evaluation was the highlighting of health and financial services as an area of concern for rural communities and for areas with high deprivation scores. This theory was confirmed through the 
community perception interviews (refer to Appendix I: 1.4

Community Life Interview Responses) as a health centre initiative for the Titoki area was in the infant stages of development.

The second segment of empirical research focused on the rural context and the community-accepted architectural interpretation of identity. As the definition of the rural context investigated in this thesis focused on the agricultural nature of the community, and as Titoki was identified as the specific context of the design phase, it is the agricultural vernacular of Titoki explored for the tangible qualities of its design. The results of this exploration, combined with a survey of the rural community hall typology, provided the criteria for vernacular design of a recognisable and acceptable community building in the rural context.

\section{Design}

The devised criterion was tested through a design case study in Titoki. Design using this method for creating the criteria set boundaries, which did not cover all areas of community design. The result was an agricultural aesthetic for a community-orientated building. As the process for setting the criteria did not address other issues outside of the agricultural vernacular and community hall typology, these were not dealt with in the design. Designing for a community outside this research would need to engage with the community to have them explain who they are and what they want.

\section{Challenges/Possibilities to the Research}

Little direct information was found in the sociological literature concerning the rural context. This was also true of the architectural literature, where direct information on designing community in the rural context is scarce. Whilst this initially posed a challenge, it opened the research up to the possibility of empirical research based on the more generalised findings in the literature specific to the case study community.

\section{Difficulties/Limitations}

The biggest difficulty faced with this research was the physical distance to the sample group from the research base. This limited time in the communities observing and collecting raw data.

Difficulties were also faced with the collection of data - access to farm shed and community halls, and the availability and willingness of the interviewees. This limited the community cross section of data able to be gathered. As the sociological theories reviewed did not cover issues of ethnicity (for the New Zealand rural context in Northland, Maori is quite prevalent) this area is also limited in the research. Up-to-date statistical information was also scarce. 


\section{Development/Improvement}

The empirical research would be strengthened by:

- Sampling of a larger group of rural communities across regions

- Community public forums as well as interviews

- Community population and household figures of density

- Historical research into community of the areas

\section{Application to Practice}

This research is of significance when designs are required for community buildings or services in the rural context. The theory of deprivation can be applied to the community to determine what program is suitable. Density and development highlights the best position to cultivate community. Social interaction opportunities theory looks to cluster the development with other community services. The principles of these theories are able to be externally applied and deliver an impartial result of what, and where, it is needed. The results in this thesis's sample group reflect the communities' perceptions. Acceptance by the community is an area that will be unique to the community in which the building is sited this is not a theory proved but used in this thesis as the proposed design is hypothetical.

\section{Conclusion}

This thesis presents a method for designing in the rural New Zealand context to cultivate community. To conclude, the sociological and architectural theories of deprivation, density and development, and social interaction opportunities as determinants of community are applicable to the rural context. The architectural representation of these theories depicts the community perception in the rural context. Designing a community-orientated program based on these and the theories of rural vernacular generates design that excludes other factors specific to the rural community of choice. The limitations of the research process directed the design process to a generic rural community design. In this thesis, it lead to an agriculturally inspired aesthetic to the architecture, one that could be transposed to any number of agriculturally dependent rural communities. Because of this the program of a Heartland Centre is but one in an integrated network of centres across rural districts one that can bridge across many communities in the rural context. Architecture acts as a vehicle to cultivate a socially wealthy and content community that will work together to prosper in the rural context. A community working together is economically more successful. 


\section{Titoki Community Feedback}

During informal discussions with Titoki community members late in the research, it was discovered that the community have a proposal to initiate a health centre for the area. Their current proposal is to house this in the old school building within the school grounds. In this thesis, it has been noted that this placement may not be ideal as it creates a level of exclusivity by being within the school. This selfinitiated health centre is in response to a need in the community that the community has highlighted themselves. This proves that the research undertaken in this thesis is one way to assess what communities in the rural context require. By incorporating the principles as outlined throughout the thesis into the design of a health and community focussed building for the rural community of Titoki, a greater sense of community can be cultivated. This will support the body of existing residents and as they develop, to become a more independent and self-sufficient community where the business of farming for New Zealand will flourish. 
The limitations placed on this thesis raise further questions that can be investigated for the cultivation of community in the rural context. There are other issues surrounding the design of community that need additional exploration as to the applicableness to the rural context. Further investigations may include:

- Research in to the ethnic, cultural and historical nature of the community.

- Testing other rural community areas around New Zealand to see if the conclusions from this sample are part of an established pattern across rural New Zealand.

- Research into the placement of Heartland Centres in other rural community areas

- Exploration into the level of remoteness and its effect on the rural community

- Exploration into the services offered in the associated urban area and its effect on the rural community

- Investigate the process of community design - previous architecturally designed community buildings and how well the communities have responded to them
These are but a few suggestions for future research in this field. The answer to these questions may devise a different framework and criteria for an architectural intervention to help community in the rural context flourish. 
8.0 Appendix: 


\section{appendix contents}

page |appendix

94 Appendix I: Sample Communities

$95 \quad 1.1$ Photographic Documentation of Sample Communities

$98 \quad 1.2$ Human Ethics Committee Approval

$99 \quad 1.3$ Community Life Interview Questions

$101 \quad 1.4$ Community Life Interview Responses

110 Appendix II: Deprivation

1112.1 Deprivation Index Determinants

1152.2 Deprivation Distribution
116 Appendix III: Services and

Employment Opportunities

$117 \quad 3.1$ Businesses Advertising in Sample

Communities

119 Appendix IV: Rural Vernacular Architecture

120 4.1 Agricultural Farm Shed Data

125 Appendix V: Community Hall Typology

$126 \quad 5.1$ Community Hall Assessment Criteria

$130 \quad 5.2$ Community Hall Data
1325.3 Community Hall Evaluations

142 5.4 Community Hall Analysis; Case Study Halls

150 Appendix VI: Design Process

151 6.1 Design Exploration - Physical Modelling

6.2 Proposed Design

1736.3 Proposed Design - Physical Model 
Appendix I: Sample Communities 


\section{Titoki}
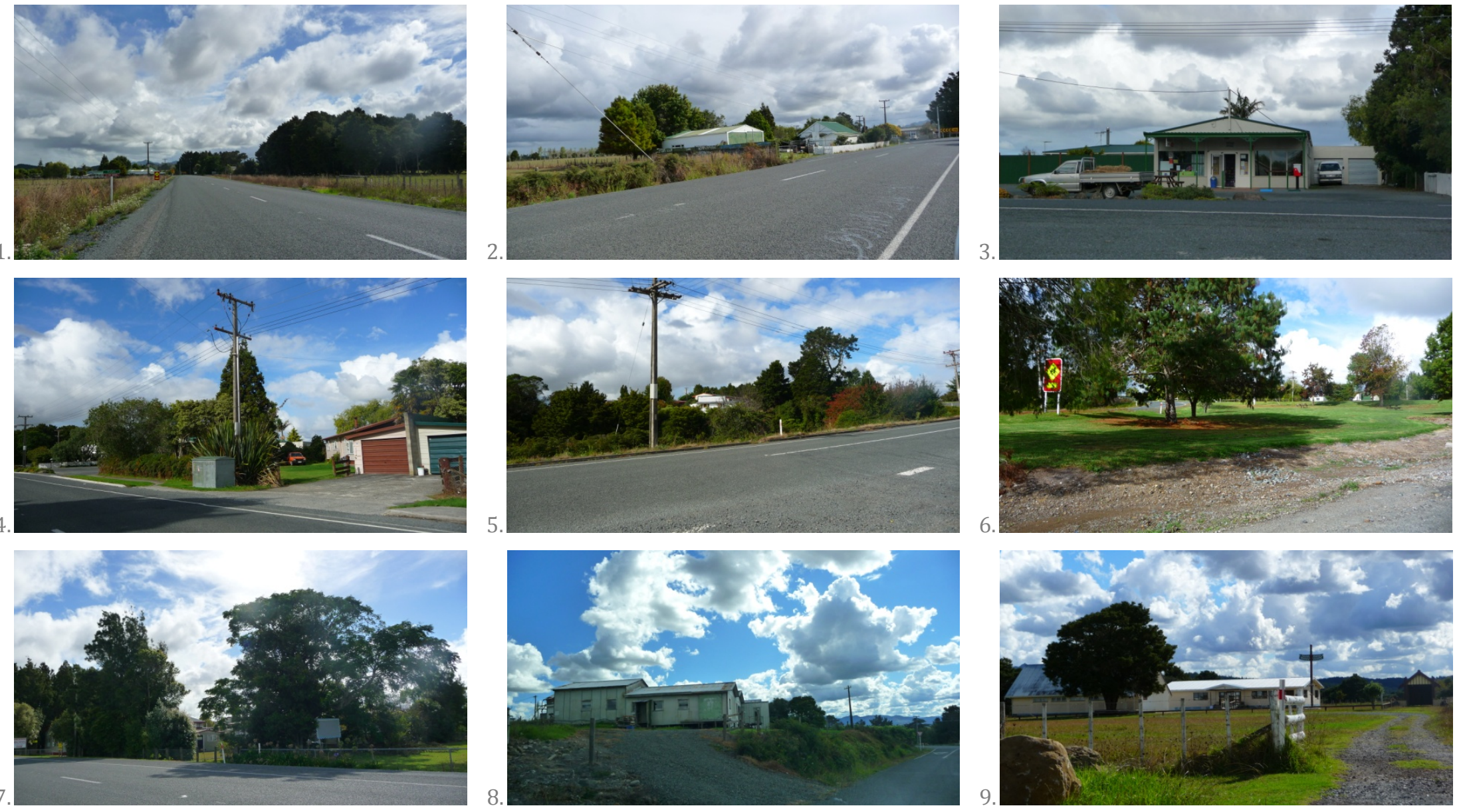

8.1.1a: Titoki Community 1. Entrance to Titoki with farmland either side; 2. Residential; 3. Titoki Store; 4. Residential relationship to street; 5. Steep gully across Mangakahia Road to School; 6. Park area central to community; 7. Entrance to School and Play centre; 8. Derelict warehouse; 9. Korokota Marae, Titoki. 
Maungatapere
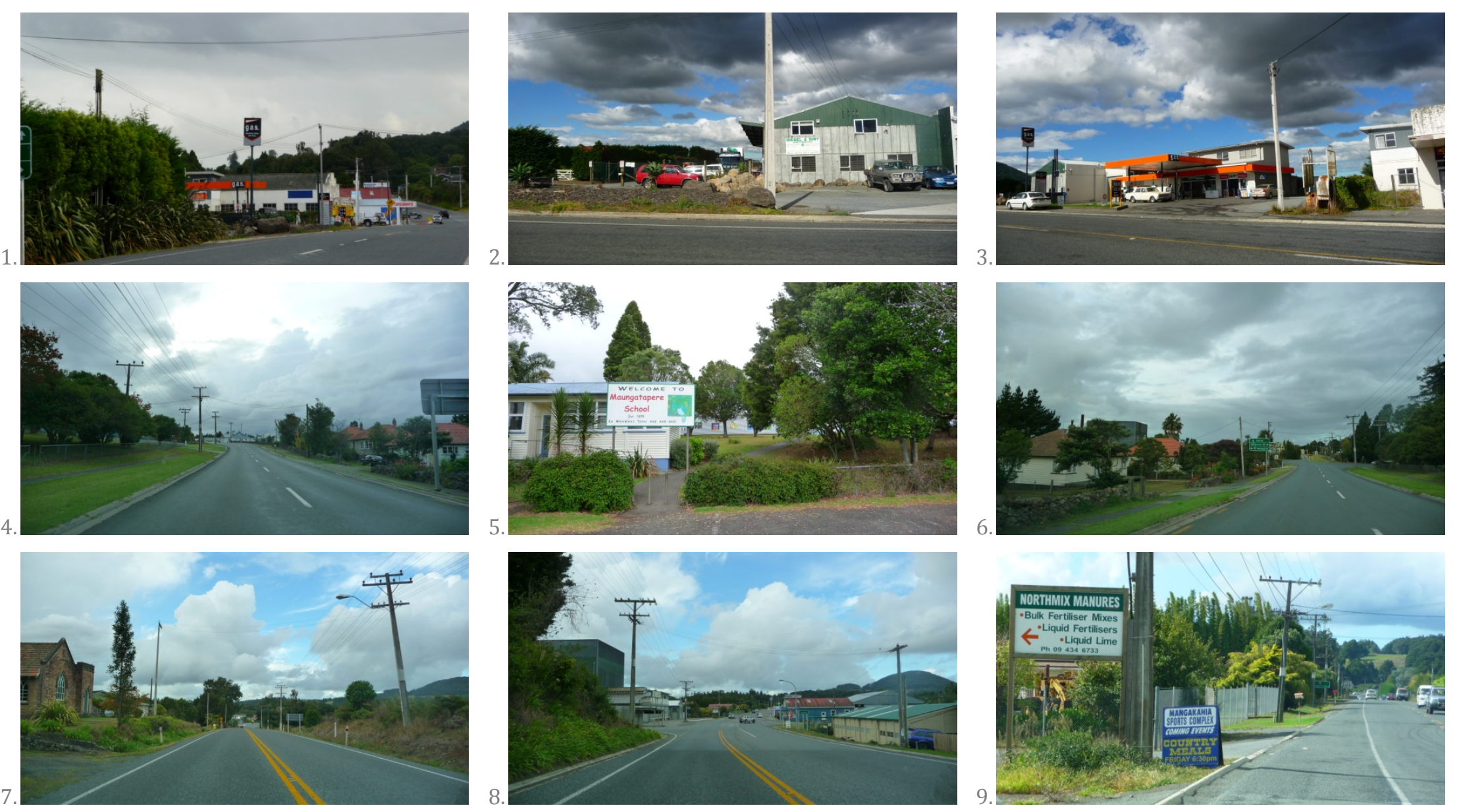

8.1.1b: Maungatapere Community 1. Entrance to Maungatapere; 2. Commercial businesses; 3. Commercial businesses; 4. Primary school on left, residential on right; 5. Maungatapere School with dental nurse house; 6. State housing residential with Dairy Factory beyond; 7. Memorial Church on left looking back into Maungatapere; 8. Commercial on right with Dairy factory on left beyond; 9. Roadside advertisement along State Highway 14, Maungatapere. 
Maungakaramea
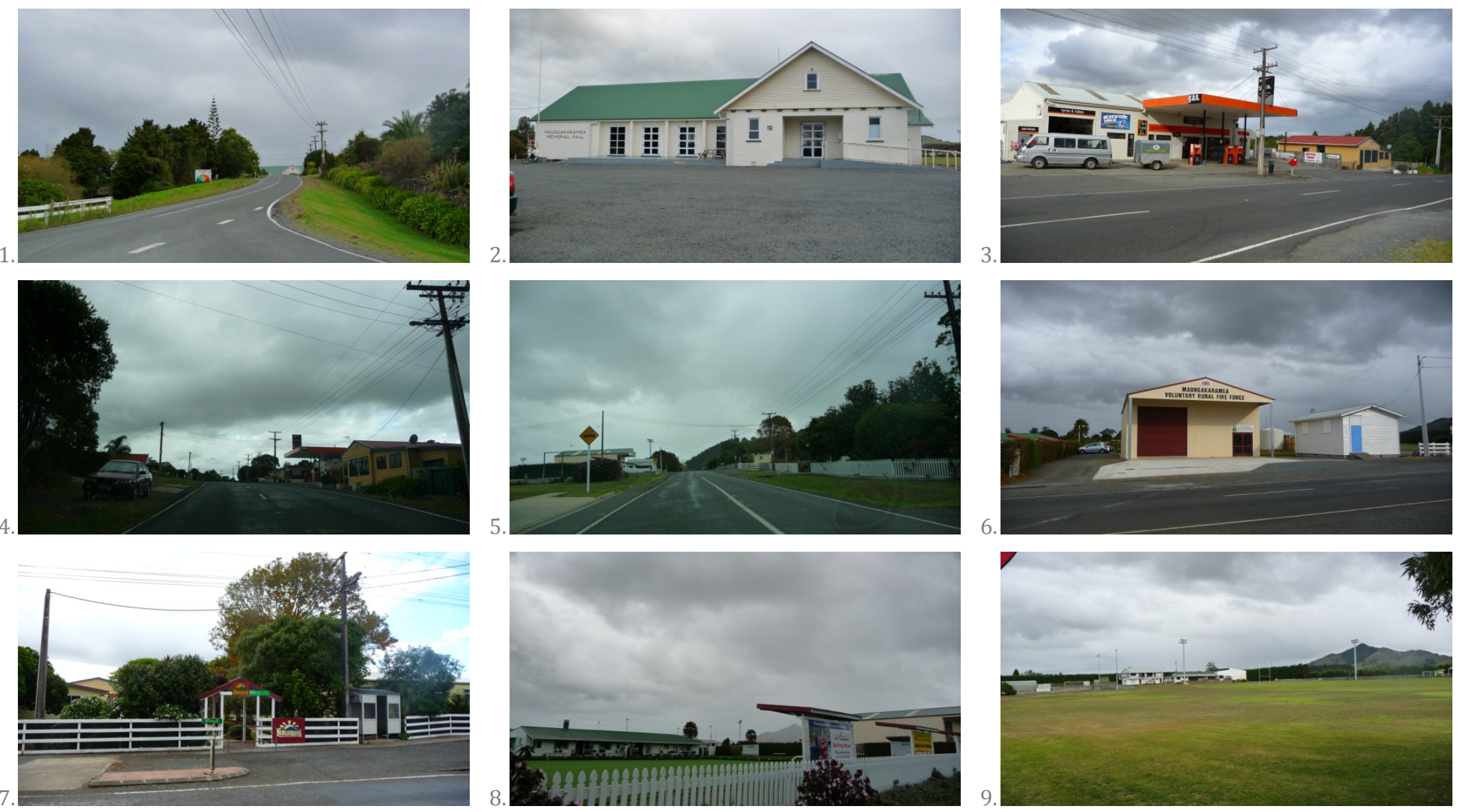

8.1.1c: Maungakaramea Community; 1. Entrance to Maungakaramea; 2.Maungakaramea Memorial Hall; 3. Commercial businesses; 4. Building relationship to street; 5. Large verge on roadsides with Hall and volunteer fire brigade beyond on left and school on right; 6. Volunteer Fire Brigade; 7. School entrance; 8. Bowling greens; 9. Maungakaramea Sporting complex with fields, courts, squash and rugby clubrooms, and gym, Sale yards beyond. 


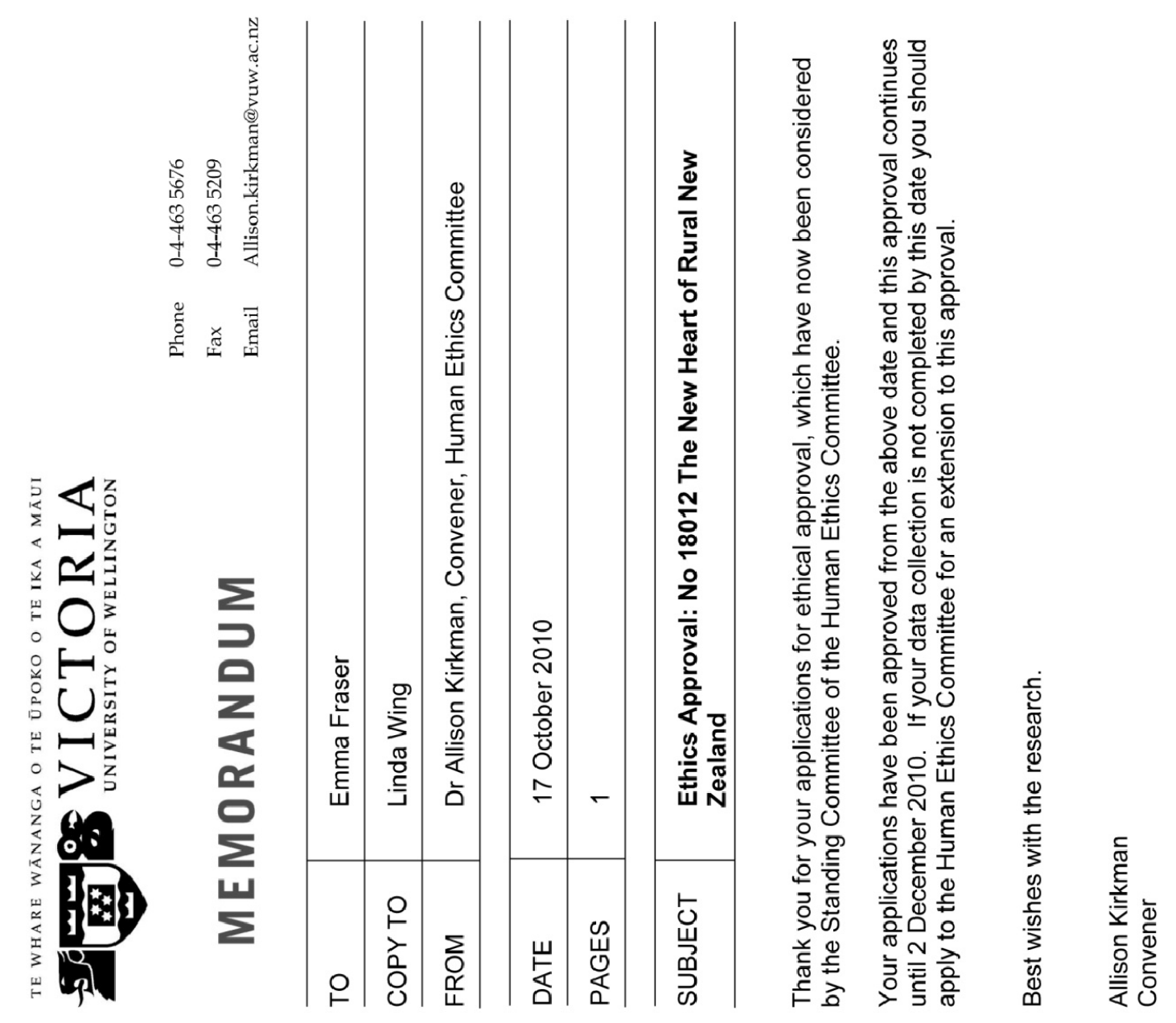




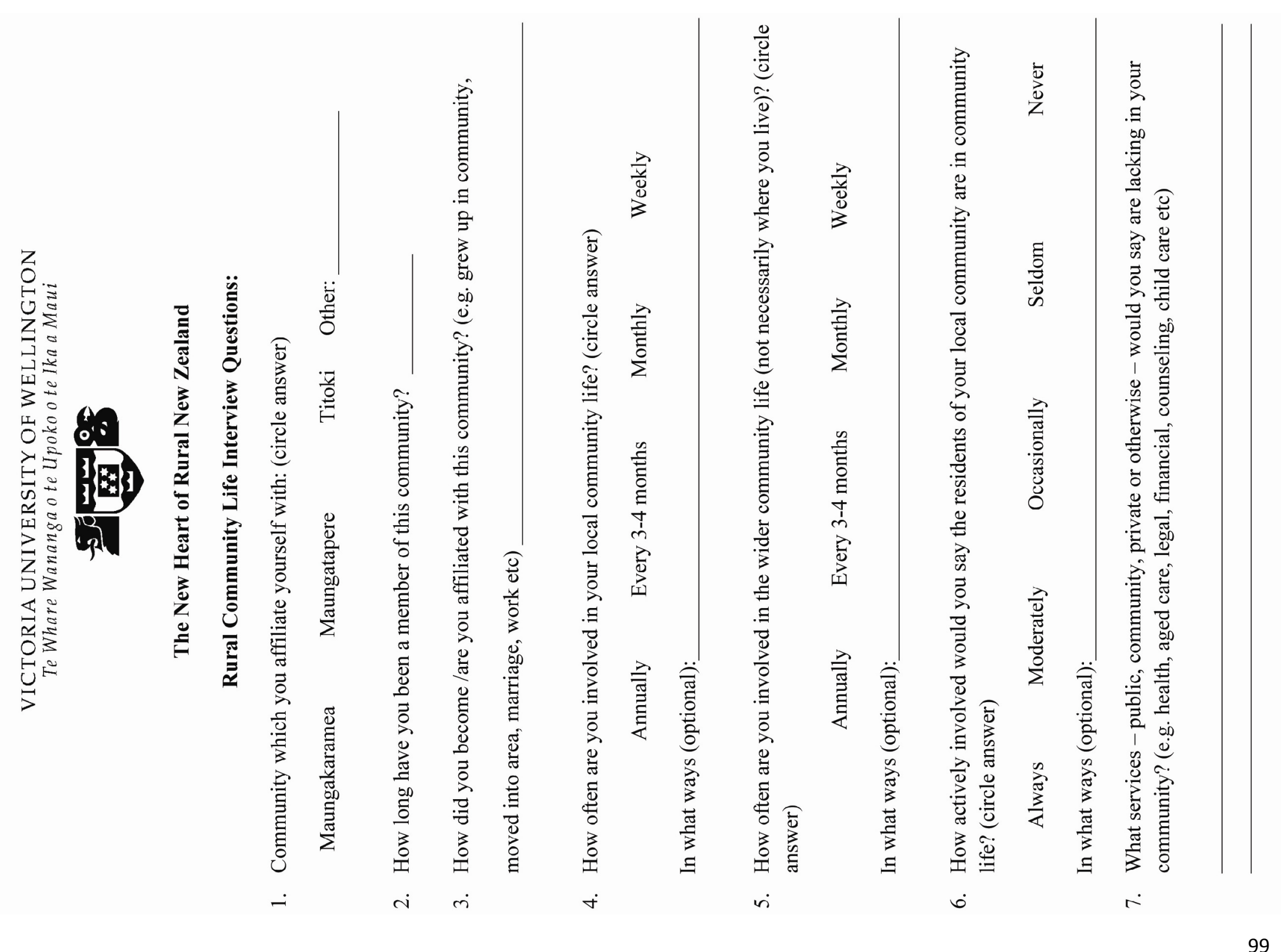



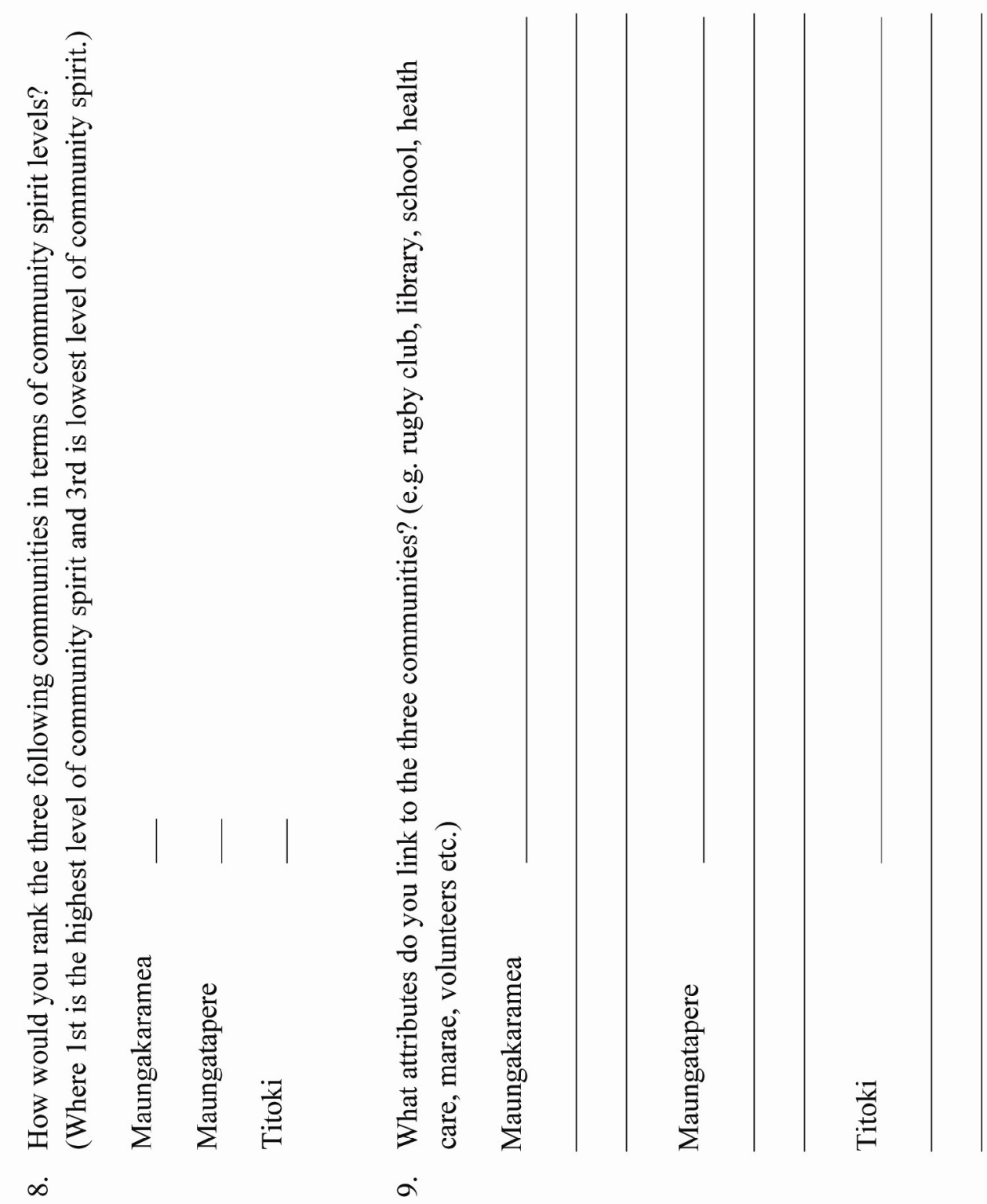
1.4 Community Life Interview Responses

\begin{tabular}{|c|c|c|c|c|c|}
\hline & \multirow{2}{*}{\begin{tabular}{|l|} 
Participant \\
\end{tabular}} & \multicolumn{2}{|c|}{1} & \multicolumn{2}{|c|}{2} \\
\hline \# & & Answer & Comment & Answer & Comment \\
\hline 1 & $\begin{array}{l}\text { Which community do you affiliate yourself } \\
\text { with? }\end{array}$ & Other & Tangiteroria & Other & Whatitiri \\
\hline 2 & $\begin{array}{l}\text { How long have you been a member in this } \\
\text { community? }\end{array}$ & 8yrs & & 21yrs & \\
\hline 3 & $\begin{array}{l}\text { How did you become/are you affiliated with } \\
\text { this community? }\end{array}$ & Moved from Auckland & Moved for the lifestyle & Moved into area & \\
\hline 4 & $\begin{array}{l}\text { How often are you involved in your local } \\
\text { community life? }\end{array}$ & Weekly & Get together at hall - 10people & Never & \\
\hline 5 & $\begin{array}{l}\text { How often are you involved in the wider } \\
\text { community life (not necessarily where you } \\
\text { live)? }\end{array}$ & Monthly & P.O.C (Poroti Outdoors Club) & Bi-Monthly & P.O.C, Rugby \\
\hline 6 & $\begin{array}{l}\text { How actively involved in the community } \\
\text { would you say the residents of your local } \\
\text { community are in community life? }\end{array}$ & Seldom & & Moderately & Hall \\
\hline & $\begin{array}{l}\text { What services - public, community, private or } \\
\text { otherwise - would you say are lacking in your } \\
\text { community? }\end{array}$ & \multicolumn{2}{|c|}{ Isolated - Health - ambulances get lost } & \multicolumn{2}{|l|}{ N/A } \\
\hline 8 & $\begin{array}{l}\text { How would you rank the following } \\
\text { communities in terms of community spirit } \\
\text { levels? Maungakaramea }\end{array}$ & \multicolumn{2}{|l|}{1} & \multicolumn{2}{|l|}{1} \\
\hline & Maungatapere & \multicolumn{2}{|l|}{3} & \multicolumn{2}{|l|}{3} \\
\hline & Titoki & \multicolumn{2}{|l|}{2} & \multicolumn{2}{|l|}{2} \\
\hline 9 & $\begin{array}{l}\text { What attributes do you associate to the three } \\
\text { communities? Maungakaramea }\end{array}$ & \multicolumn{2}{|l|}{ Rugby, Market, School } & \multicolumn{2}{|l|}{ Hall, Sports Complex } \\
\hline & Maungatapere & \multicolumn{2}{|c|}{ Petrol, MTL (Maungatapere Transport Limited) } & \multicolumn{2}{|l|}{ Hall, the "Office" } \\
\hline & Titoki & \multicolumn{2}{|l|}{ School } & \multicolumn{2}{|c|}{ Play centre, School, Church and Community Hall in the School } \\
\hline 10 & Further comments & \multicolumn{2}{|l|}{ - } & \multicolumn{2}{|l|}{-} \\
\hline \multirow{4}{*}{ 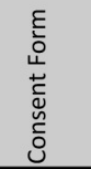 } & I would like to check my interview notes? & \multicolumn{2}{|l|}{ N } & \multicolumn{2}{|l|}{$\mathrm{N}$} \\
\hline & Confidential//dentified & \multicolumn{2}{|c|}{ Identified - Dave Blakey; Agricultural Consultant } & \multicolumn{2}{|c|}{ Identified - J. M. Hawkins; Agricultural Consultant } \\
\hline & Date & \multicolumn{2}{|l|}{8 -Nov } & \multicolumn{2}{|l|}{8 -Nov } \\
\hline & Contact Address & \multicolumn{2}{|l|}{ N/A } & \multicolumn{2}{|l|}{ N/A } \\
\hline
\end{tabular}




\begin{tabular}{|c|c|c|c|c|c|}
\hline & Participant & \multicolumn{2}{|c|}{3} & \multicolumn{2}{|c|}{4} \\
\hline$\#$ & Question & Answer & Comment & Answer & Comment \\
\hline 1 & $\begin{array}{l}\text { Which community do you affiliate yourself } \\
\text { with? }\end{array}$ & Titoki & & Maungatapere & \\
\hline 2 & $\begin{array}{l}\text { How long have you been a member in this } \\
\text { community? }\end{array}$ & $6-7 y r s$ & & $15 y$ ys & \\
\hline 3 & $\begin{array}{l}\text { How did you become/are you affiliated with } \\
\text { this community? }\end{array}$ & Work & & Brought property & \\
\hline 4 & $\begin{array}{l}\text { How often are you involved in your local } \\
\text { community life? }\end{array}$ & Daily & Work & Never & \\
\hline 5 & $\begin{array}{l}\text { How often are you involved in the wider } \\
\text { community life (not necessarily where you } \\
\text { live)? }\end{array}$ & Never & & Bi-monthly & Growers group \\
\hline 6 & $\begin{array}{l}\text { How actively involved in the community } \\
\text { would you say the residents of your local } \\
\text { community are in community life? }\end{array}$ & Occasionally & & Mixed & $\begin{array}{l}\text { Pockets of active members of } \\
\text { associations - bowls, rodeo }\end{array}$ \\
\hline 7 & $\begin{array}{l}\text { What services - public, community, private or } \\
\text { otherwise - would you say are lacking in your } \\
\text { community? }\end{array}$ & \multicolumn{2}{|l|}{ N/A } & \multicolumn{2}{|l|}{ N/A } \\
\hline 8 & $\begin{array}{l}\text { How would you rank the following } \\
\text { communities in terms of community spirit } \\
\text { levels? Maungakaramea }\end{array}$ & \multicolumn{2}{|l|}{ N/A } & \multicolumn{2}{|l|}{2} \\
\hline & Maungatapere & \multicolumn{2}{|l|}{ N/A } & \multicolumn{2}{|l|}{1} \\
\hline & Titoki & \multicolumn{2}{|l|}{$\mathrm{N} / \mathrm{A}$} & \multicolumn{2}{|l|}{3} \\
\hline 9 & $\begin{array}{l}\text { What attributes do you associate to the three } \\
\text { communities? Maungakaramea }\end{array}$ & \multicolumn{2}{|l|}{ N/A } & \multicolumn{2}{|l|}{ Rugby and Cricket } \\
\hline & Maungatapere & \multicolumn{2}{|l|}{ Good School } & \multicolumn{2}{|c|}{ School, Clubs, Post Office, MTL, general store } \\
\hline & Titoki & \multicolumn{2}{|c|}{ Good School, Much the same as Maungatapere } & & \\
\hline 10 & Further comments & \multicolumn{2}{|c|}{ Health centre in the old school building would be great } & \multicolumn{2}{|c|}{$\begin{array}{l}\text { Zoning changes in Maungatapere - } 1 \text { acre blocks vs. } 10 \text { acre } \\
\text { subdivision - a satellite town of Whangarei. }\end{array}$} \\
\hline \multirow{4}{*}{ 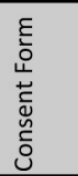 } & I would like to check my interview notes? & \multicolumn{2}{|l|}{ Y } & \multicolumn{2}{|l|}{$\mathrm{N}$} \\
\hline & Confidential/Identified & \multicolumn{2}{|c|}{ Identified - John Laird; Local Business Operator } & \multicolumn{2}{|c|}{ Identified - Chris Fraser; Horticultural Farmer } \\
\hline & Date & \multicolumn{2}{|l|}{ 11-Nov } & \multicolumn{2}{|l|}{ 12-Nov } \\
\hline & Contact Address & \multicolumn{2}{|l|}{ N/A } & \multicolumn{2}{|l|}{ N/A } \\
\hline
\end{tabular}

| 102 


\begin{tabular}{|c|c|c|c|c|c|}
\hline & Participant & \multicolumn{2}{|c|}{5} & \multicolumn{2}{|c|}{6} \\
\hline$\#$ & Question & Answer & Comment & Answer & Comment \\
\hline 1 & $\begin{array}{l}\text { Which community do you affiliate yourself } \\
\text { with? }\end{array}$ & Maungatapere & & Maungakaramea & \\
\hline 2 & $\begin{array}{l}\text { How long have you been a member in this } \\
\text { community? }\end{array}$ & 36yrs & & $35 y r s$ & \\
\hline 3 & $\begin{array}{l}\text { How did you become/are you affiliated with } \\
\text { this community? }\end{array}$ & Brought property & & Business & \\
\hline 4 & $\begin{array}{l}\text { How often are you involved in your local } \\
\text { community life? }\end{array}$ & Weekly & Café, business & Daily & $\begin{array}{l}\text { Squash, Biking, Indoor Bowls, Hall } \\
\text { Committee - Recreational group - run } \\
\text { grounds }\end{array}$ \\
\hline & $\begin{array}{l}\text { How often are you involved in the wider } \\
\text { community life (not necessarily where you } \\
\text { live)? }\end{array}$ & Daily & & Never & \\
\hline & $\begin{array}{l}\text { How actively involved in the community } \\
\text { would you say the residents of your local } \\
\text { community are in community life? }\end{array}$ & $\mathrm{N} / \mathrm{A}$ & School Newsletter in the post & Mixed & $\begin{array}{l}\text { Hard to get people involved - Hall } \\
\text { used to be well supported. }\end{array}$ \\
\hline & $\begin{array}{l}\text { What services - public, community, private or } \\
\text { otherwise - would you say are lacking in your } \\
\text { community? }\end{array}$ & \multicolumn{2}{|c|}{$\begin{array}{l}\text { Doctors - has hospital backing; Apartments; Hairdresser; } \\
\text { Physio is out twice a week }\end{array}$} & \multicolumn{2}{|l|}{ Well covered } \\
\hline & $\begin{array}{l}\text { How would you rank the following } \\
\text { communities in terms of community spirit } \\
\text { levels? Maungakaramea }\end{array}$ & \multicolumn{2}{|l|}{$\mathrm{N} / \mathrm{A}$} & \multicolumn{2}{|l|}{$\mathrm{N} / \mathrm{A}$} \\
\hline & Maungatapere & \multicolumn{2}{|l|}{ N/A } & \multicolumn{2}{|l|}{ N/A } \\
\hline & Titoki & \multicolumn{2}{|l|}{ N/A } & \multicolumn{2}{|l|}{ N/A } \\
\hline 9 & $\begin{array}{l}\text { What attributes do you associate to the three } \\
\text { communities? Maungakaramea }\end{array}$ & \multicolumn{2}{|l|}{$\mathrm{N} / \mathrm{A}$} & \multicolumn{2}{|c|}{$\begin{array}{l}\text { Bowls/hall usage is diminishing - support getting less. Great } \\
\text { area. Sports area. Good school - bring up kids. Well } \\
\text { supported by the community - local business }\end{array}$} \\
\hline & Maungatapere & \multicolumn{2}{|l|}{ N/A } & \multicolumn{2}{|c|}{ Bowls - couple of times a year. } \\
\hline & Titoki & \multicolumn{2}{|l|}{ N/A } & \multicolumn{2}{|l|}{ N/A } \\
\hline 10 & Further comments & \multicolumn{2}{|l|}{ N/A } & \multicolumn{2}{|c|}{ Trouble with getting people involved to get things done } \\
\hline \multirow{4}{*}{ 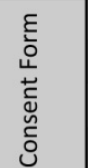 } & I would like to check my interview notes? & \multicolumn{2}{|l|}{$\mathrm{N}$} & \multicolumn{2}{|l|}{$\mathrm{N}$} \\
\hline & Confidential/Identified & \multicolumn{2}{|c|}{ Identified - G. R. Sandilands; Established Resident } & \multicolumn{2}{|c|}{ Identified - John McKinney; Local Business Operator } \\
\hline & Date & \multicolumn{2}{|l|}{ 11-Nov } & \multicolumn{2}{|l|}{ 11-Nov } \\
\hline & Contact Address & \multicolumn{2}{|l|}{ N/A } & \multicolumn{2}{|l|}{ N/A } \\
\hline
\end{tabular}




\begin{tabular}{|c|c|c|c|c|c|}
\hline & Participant & \multicolumn{2}{|c|}{7} & \multicolumn{2}{|c|}{8} \\
\hline \# & Question & Answer & Comment & Answer & Comment \\
\hline 1 & $\begin{array}{l}\text { Which community do you affiliate yourself } \\
\text { with? }\end{array}$ & Maungakaramea & & Maungakaramea & \\
\hline 2 & $\begin{array}{l}\text { How long have you been a member in this } \\
\text { community? }\end{array}$ & $30 y r s$ & & $55 y$ yrs & \\
\hline 3 & $\begin{array}{l}\text { How did you become/are you affiliated with } \\
\text { this community? }\end{array}$ & Marriage & & Born in the area & \\
\hline & $\begin{array}{l}\text { How often are you involved in your local } \\
\text { community life? }\end{array}$ & Weekly & Rugby, Anglican Church, School & Monthly & Recreational Society, Hockey \\
\hline 5 & $\begin{array}{l}\text { How often are you involved in the wider } \\
\text { community life (not necessarily where you } \\
\text { live)? }\end{array}$ & Daily & Garage, Work & Monthly & Oakleigh Fishing Club \\
\hline 6 & $\begin{array}{l}\text { How actively involved in the community } \\
\text { would you say the residents of your local } \\
\text { community are in community life? }\end{array}$ & Mixed & Varied & Mixed & $\begin{array}{l}\text { Locals - active. Lifestyle blocks- little } \\
\text { to do with the community }\end{array}$ \\
\hline & $\begin{array}{l}\text { What services - public, community, private or } \\
\text { otherwise - would you say are lacking in your } \\
\text { community? }\end{array}$ & \multicolumn{2}{|c|}{$\begin{array}{l}\text { Commute to town therefore no lack. There is Post-surgical, } \\
\text { public health nurse, Rubicon (teenage drug addiction) }\end{array}$} & \multicolumn{2}{|c|}{ Fire Service. Lack of industrial or commercial zones } \\
\hline 8 & $\begin{array}{l}\text { How would you rank the following } \\
\text { communities in terms of community spirit } \\
\text { levels? Maungakaramea }\end{array}$ & \multicolumn{2}{|l|}{ N/A } & \multicolumn{2}{|l|}{1} \\
\hline & Maungatapere & \multicolumn{2}{|l|}{ N/A } & \multicolumn{2}{|l|}{2} \\
\hline & Titoki & \multicolumn{2}{|l|}{ N/A } & \multicolumn{2}{|l|}{ N/A } \\
\hline 9 & $\begin{array}{l}\text { What attributes do you associate to the three } \\
\text { communities? Maungakaramea }\end{array}$ & \multicolumn{2}{|c|}{$\begin{array}{l}\text { Newer residents commute - not as involved. Rental Houses - } \\
\text { undesirable tenants attracted. An increase in petty/nuisance } \\
\text { crime }\end{array}$} & \multicolumn{2}{|c|}{ Sporting Clubs, Sale yards committee } \\
\hline & Maungatapere & \multicolumn{2}{|l|}{ N/A } & \multicolumn{2}{|c|}{ Strong horticultural area with pack houses for employment } \\
\hline & Titoki & \multicolumn{2}{|c|}{ N/A } & \multicolumn{2}{|l|}{ N/A } \\
\hline 10 & Further comments & \multicolumn{2}{|c|}{$\begin{array}{l}\text { Caring bonded community. The road to Dargaville is a divider. } \\
\text { Active Sale yards to fund community. Retirement village - } \\
\text { others from outer area moved in. Dental service bus. Fire } \\
\text { service, bowling, gvm, squash, rugbv, } 3 \text { churches all in the }\end{array}$} & \multicolumn{2}{|c|}{$\begin{array}{l}\text { Lack of community spirit in } \mathrm{t} \text { lifestyle block residents - don't } \\
\text { feel they want to get involved. }\end{array}$} \\
\hline \multirow{4}{*}{ 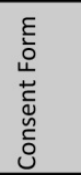 } & I would like to check my interview notes? & \multicolumn{2}{|l|}{ N } & \multicolumn{2}{|l|}{ N } \\
\hline & Confidential//Identified & \multicolumn{2}{|l|}{ Confidential } & \multicolumn{2}{|c|}{ Identified - Kelvin Attwood; Established Resident } \\
\hline & Date & \multicolumn{2}{|l|}{ 11-Nov } & \multicolumn{2}{|l|}{$11-\mathrm{Nov}$} \\
\hline & Contact Address & \multicolumn{2}{|l|}{ N/A } & \multicolumn{2}{|l|}{ N/A } \\
\hline
\end{tabular}

104 


\begin{tabular}{|c|c|c|c|c|c|}
\hline & Participant & \multicolumn{2}{|c|}{9} & \multicolumn{2}{|c|}{10} \\
\hline$\#$ & Question & Answer & Comment & Answer & Comment \\
\hline 1 & $\begin{array}{l}1 \text { Which community do you affiliate yourself } \\
\text { with? }\end{array}$ & Maungakaramea & & Maungatapere & \\
\hline 2 & $2 \begin{array}{l}\text { How long have you been a member in this } \\
\text { community? }\end{array}$ & $4.5 y r s$ & & Life & \\
\hline & $3 \begin{array}{l}\text { How did you become/are you affiliated with } \\
\text { this community? }\end{array}$ & Work & & $\begin{array}{l}\text { Moved into area with } \\
\text { family }\end{array}$ & \\
\hline & $4 \begin{array}{l}\text { How often are you involved in your local } \\
\text { community life? }\end{array}$ & Never & & |Weekly & Business, School, Sports \\
\hline & $\begin{array}{l}5 \text { How often are you involved in the wider } \\
\text { community life (not necessarily where you } \\
\text { live)? }\end{array}$ & Weekly & Whangarei Museum & Weekly & \\
\hline & 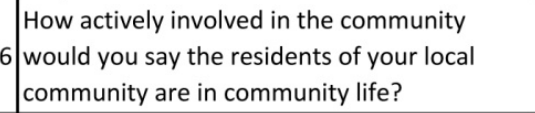 & Mixed & Varies, some are quite involved & Always & Definitely a spread though \\
\hline & $\begin{array}{l}7 \text { What services - public, community, private or } \\
\text { otherwise - would you say are lacking in your } \\
\text { community? }\end{array}$ & \multicolumn{2}{|l|}{ No difficulties } & \multicolumn{2}{|c|}{ Child care and Doctors lacking } \\
\hline & $\begin{array}{l}\text { How would you rank the following } \\
\text { communities in terms of community spirit } \\
\text { levels? Maungakaramea }\end{array}$ & \multicolumn{2}{|l|}{ N/A } & \multicolumn{2}{|l|}{1} \\
\hline & Maungatapere & \multicolumn{2}{|l|}{ N/A } & \multicolumn{2}{|l|}{2} \\
\hline & Titoki & \multicolumn{2}{|l|}{ N/A } & \multicolumn{2}{|l|}{3} \\
\hline 9 & $9 \begin{array}{l}\text { What attributes do you associate to the three } \\
\text { communities? Maungakaramea }\end{array}$ & \multicolumn{2}{|c|}{$\begin{array}{l}\text { Schooling and sporting involvement. Rural focussed. Garage } \\
\text { facilities }\end{array}$} & \multicolumn{2}{|c|}{ Family; Lots of opportunities - sports club } \\
\hline & Maungatapere & & & \multicolumn{2}{|l|}{ Poroti Area - Rugby } \\
\hline & Titoki & & & \multicolumn{2}{|l|}{ Marae } \\
\hline 10 & 0 Further comments & & & \multicolumn{2}{|c|}{ Neat community. Everybody knows everyone. Pub is a base } \\
\hline \multirow{4}{*}{ 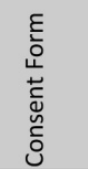 } & I would like to check my interview notes? & \multicolumn{2}{|l|}{ N } & \multicolumn{2}{|l|}{$\mathrm{N}$} \\
\hline & Confidential/Identified & \multicolumn{2}{|c|}{ Identified - Gavin Neumann; Share Milker } & \multicolumn{2}{|c|}{ Identified - Shannon Beeston; Local Business Operator } \\
\hline & Date & \multicolumn{2}{|l|}{ 11-Nov } & \multicolumn{2}{|l|}{ 11-Nov } \\
\hline & Contact Address & \multicolumn{2}{|l|}{ N/A } & \multicolumn{2}{|l|}{ N/A } \\
\hline
\end{tabular}




\begin{tabular}{|c|c|c|c|c|c|}
\hline & \multirow{2}{*}{\begin{tabular}{|l|} 
Participant \\
\end{tabular}} & \multicolumn{2}{|c|}{11} & \multicolumn{2}{|c|}{12} \\
\hline$\#$ & & Answer & Comment & Answer & Comment \\
\hline \multirow{3}{*}{$\begin{array}{l}1 \\
2 \\
3\end{array}$} & $\begin{array}{l}\text { Which community do you affiliate yourself } \\
\text { with? }\end{array}$ & Maungatapere & & Maungatapere & \\
\hline & $\begin{array}{l}\text { How long have you been a member in this } \\
\text { community? }\end{array}$ & 11yrs & & $10 y r s$ & \\
\hline & $\begin{array}{l}\text { How did you become/are you affiliated with } \\
\text { this community? }\end{array}$ & Moved into & Brought farm & work & \\
\hline 4 & $\begin{array}{l}\text { How often are you involved in your local } \\
\text { community life? }\end{array}$ & Weekly & Committees - Sporting & Daily & Work \\
\hline 5 & $\begin{array}{l}\text { How often are you involved in the wider } \\
\text { community life (not necessarily where you } \\
\text { live)? }\end{array}$ & Weekly & Stock Agent & Daily & Fundraising school, girl guides, Zumba \\
\hline 6 & $\begin{array}{l}\text { How actively involved in the community } \\
\text { would you say the residents of your local } \\
\text { community are in community life? }\end{array}$ & Occasionally & Some are very some are not & Mixed & Some very active, some not \\
\hline & $\begin{array}{l}\text { What services - public, community, private or } \\
\text { otherwise - would you say are lacking in your } \\
\text { community? }\end{array}$ & \multicolumn{2}{|c|}{$\begin{array}{l}\text { Well looked after in most areas, Public transport maybe } \\
\text { lacking }\end{array}$} & \multicolumn{2}{|c|}{$\begin{array}{l}\text { Fire brigade - just far enough from Whangarei to receive most } \\
\text { services }\end{array}$} \\
\hline 8 & $\begin{array}{l}\text { How would you rank the following } \\
\text { communities in terms of community spirit } \\
\text { levels? Maungakaramea }\end{array}$ & \multicolumn{2}{|l|}{1} & \multicolumn{2}{|c|}{2} \\
\hline & Maungatapere & \multicolumn{2}{|l|}{2} & \multicolumn{2}{|c|}{1} \\
\hline & Titoki & \multicolumn{2}{|l|}{3} & \multicolumn{2}{|l|}{3} \\
\hline \multirow[t]{3}{*}{9} & $\begin{array}{l}\text { What attributes do you associate to the three } \\
\text { communities? Maungakaramea }\end{array}$ & \multicolumn{2}{|c|}{$\begin{array}{l}\text { Close community, related - know everyone. Sporting and } \\
\text { social opportunities. School }\end{array}$} & \multicolumn{2}{|c|}{ Sporting opportunities - Hockey } \\
\hline & Maungatapere & \multicolumn{2}{|c|}{ Bigger school than Maungakaramea - good. The "office" - } & \multicolumn{2}{|c|}{ Mangkahia Complex; Play centre. Young community - } \\
\hline & Titoki & \multicolumn{2}{|c|}{ Struggling. Shop and Area School } & \multicolumn{2}{|c|}{ Marae } \\
\hline 10 & Further comments & \multicolumn{2}{|c|}{$\begin{array}{l}\text { The further out lost work. Maungatapere growing - the café, } \\
\text { Country Yard, rest home draws people out; More to offer } \\
\text { people; Smaller rural blocks - not as much involvement in the } \\
\text { community }\end{array}$} & \multicolumn{2}{|c|}{ Tend to look out for each other } \\
\hline \multirow{4}{*}{ 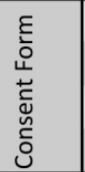 } & I would like to check my interview notes? & \multicolumn{2}{|c|}{ N } & \multicolumn{2}{|l|}{ N } \\
\hline & Confidential//dentified & \multicolumn{2}{|c|}{ Identified - Grant Aiken; Agricultural Consultant } & \multicolumn{2}{|c|}{ Identified - Pamela Holmes; Local Business Operator } \\
\hline & Date & \multicolumn{2}{|c|}{8 -Nov } & \multicolumn{2}{|c|}{ 11-Nov } \\
\hline & Contact Address & \multicolumn{2}{|l|}{ N/A } & \multicolumn{2}{|l|}{ N/A } \\
\hline
\end{tabular}




\begin{tabular}{|c|c|c|c|c|c|}
\hline & Participant & \multicolumn{2}{|c|}{13} & \multicolumn{2}{|c|}{14} \\
\hline \# & Question & Answer & Comment & Answer & Comment \\
\hline 1 & $\begin{array}{l}\text { Which community do you affiliate yourself } \\
\text { with? }\end{array}$ & Titoki & & Other & Mangapai \\
\hline 2 & $\begin{array}{l}\text { How long have you been a member in this } \\
\text { community? }\end{array}$ & 20yrs & & Life & \\
\hline 3 & $\begin{array}{l}\text { How did you become/are you affiliated with } \\
\text { this community? }\end{array}$ & Born & & Born there & \\
\hline 4 & $\begin{array}{l}\text { How often are you involved in your local } \\
\text { community life? }\end{array}$ & Daily & Work related in Titoki & Never & \\
\hline 5 & $\begin{array}{l}\text { How often are you involved in the wider } \\
\text { community life (not necessarily where you } \\
\text { live)? }\end{array}$ & Bi monthly & & Monthly & work \\
\hline 6 & $\begin{array}{l}\text { How actively involved in the community } \\
\text { would you say the residents of your local } \\
\text { community are in community life? }\end{array}$ & Occasionally & & Always & Socials, gatherings, galas, markets \\
\hline 7 & $\begin{array}{l}\text { What services - public, community, private or } \\
\text { otherwise - would you say are lacking in your } \\
\text { community? }\end{array}$ & Health; Petrol & & Health & \\
\hline 8 & $\begin{array}{l}\text { How would you rank the following } \\
\text { communities in terms of community spirit } \\
\text { levels? Maungakaramea }\end{array}$ & 1 & & 1 & \\
\hline & Maungatapere & 2 & & 2 & \\
\hline & Titoki & 3 & & 3 & \\
\hline 9 & $\begin{array}{l}\text { What attributes do you associate to the three } \\
\text { communities? Maungakaramea }\end{array}$ & $\begin{array}{l}\text { Sports clubs; } \\
\text { with a better } \\
\text { and close to a }\end{array}$ & $\begin{array}{l}\text { mmunity - more opportunities. Schools } \\
\text { on - closer to State Highway. Lifestyle } \\
\end{array}$ & Social, lots & ities to engage - bowling, rugby, sports \\
\hline & Maungatapere & Too close to $t$ & rages and café - pass through. & Slightly upp & \\
\hline & Titoki & Pub and Spor & ex - Poroti. School. Population & N/A & \\
\hline 10 & Further comments & $\begin{array}{l}\text { Titoki would } r \\
\text { Maungakaran }\end{array}$ & $\begin{array}{l}\text { n number } 1 \text { - depopulated. } \\
\text { stylers who gravitate towards clubs. }\end{array}$ & & \\
\hline \multirow{4}{*}{ 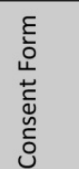 } & I would like to check my interview notes? & N & & $\mathrm{N}$ & \\
\hline & Confidential/Identified & Identified - Ga & er; Agricultural Consultant & Confidentia & \\
\hline & Date & 10-Nov & & 11-Nov & \\
\hline & Contact Address & N/A & & N/A & \\
\hline
\end{tabular}




\begin{tabular}{|c|c|c|c|c|c|}
\hline & Participant & \multicolumn{2}{|c|}{15} & \multicolumn{2}{|c|}{16} \\
\hline \# & Question & Answer & Comment & Answer & Comment \\
\hline 1 & $\begin{array}{l}\text { Which community do you affiliate yourself } \\
\text { with? }\end{array}$ & Titoki & & Titoki & \\
\hline 2 & $\begin{array}{l}\text { How long have you been a member in this } \\
\text { community? }\end{array}$ & $22 y r s$ & & $20 y r s$ & \\
\hline 3 & $\begin{array}{l}\text { How did you become/are you affiliated with } \\
\text { this community? }\end{array}$ & Married into & & Moved & from Auckland fro the lifestyle \\
\hline 4 & $\begin{array}{l}\text { How often are you involved in your local } \\
\text { community life? }\end{array}$ & Weekly & More in past, local store & Daily & School, clubs monthly dinners \\
\hline 5 & $\begin{array}{l}\text { How often are you involved in the wider } \\
\text { community life (not necessarily where you } \\
\text { live)? }\end{array}$ & Daily & Work & Annually & Northland School Association \\
\hline 6 & $\begin{array}{l}\text { How actively involved in the community } \\
\text { would you say the residents of your local } \\
\text { community are in community life? }\end{array}$ & Mixed & Group - quite strong, diverse range & Mixed & Sports dinners well supported \\
\hline 7 & $\begin{array}{l}\text { What services - public, community, private or } \\
\text { otherwise - would you say are lacking in your } \\
\text { community? }\end{array}$ & \multicolumn{2}{|c|}{$\begin{array}{l}\text { Commuting in and out therefore no lack seen, possibly in } \\
\text { health }\end{array}$} & \multicolumn{2}{|c|}{ Health services. Police and Fire services } \\
\hline 8 & $\begin{array}{l}\text { How would you rank the following } \\
\text { communities in terms of community spirit } \\
\text { levels? Maungakaramea }\end{array}$ & \multicolumn{2}{|l|}{1} & \multicolumn{2}{|l|}{3} \\
\hline & Maungatapere & \multicolumn{2}{|l|}{3} & \multicolumn{2}{|l|}{2} \\
\hline & Titoki & \multicolumn{2}{|l|}{2} & \multicolumn{2}{|l|}{1} \\
\hline 9 & $\begin{array}{l}\text { What attributes do you associate to the three } \\
\text { communities? Maungakaramea }\end{array}$ & \multicolumn{2}{|c|}{$\begin{array}{l}\text { Strong sports - complex, rugby club, sewing group. Many } \\
\text { opportunities }\end{array}$} & \multicolumn{2}{|l|}{ N/A } \\
\hline & Maungatapere & \multicolumn{2}{|c|}{ Sign up for Zumba displayed at intersection } & \multicolumn{2}{|c|}{ A lot of cross linking with Titoki, supportive of each other } \\
\hline & Titoki & \multicolumn{2}{|c|}{ School a strong centre. Play centre has ups and downs. } & \multicolumn{2}{|c|}{ Socialising in the community. Rurally isolated } \\
\hline 10 & Further comments & \multicolumn{2}{|c|}{$\begin{array}{l}\text { Titoki sports complex/pub - more use in recent years. Rugby } \\
\text { and squash club raising image. Health centre in the Old School } \\
\text { building initiative proposed by Dawn Eades -Teacher Aid at }\end{array}$} & \multicolumn{2}{|c|}{$\begin{array}{l}\text { If something goes wrong [Titoki] will rally to help. Titoki more } \\
\text { historically linked - Maungatapere is newer community }\end{array}$} \\
\hline \multirow{4}{*}{ 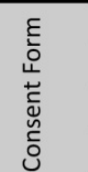 } & I would like to check my interview notes? & \multicolumn{2}{|l|}{$\mathrm{N}$} & \multicolumn{2}{|l|}{$\mathrm{N}$} \\
\hline & Confidential/Identified & \multicolumn{2}{|c|}{ Identified - Cushla Gavin; Established Resident } & \multicolumn{2}{|c|}{ Identified - Lesley McCardle; School Representative } \\
\hline & Date & \multicolumn{2}{|l|}{ 11-Nov } & \multicolumn{2}{|l|}{$11-\mathrm{Nov}$} \\
\hline & Contact Address & \multicolumn{2}{|l|}{ N/A } & \multicolumn{2}{|l|}{ N/A } \\
\hline
\end{tabular}




\begin{tabular}{|c|c|c|c|c|c|c|}
\hline & Participant & \multicolumn{2}{|c|}{17} & \multicolumn{2}{|c|}{18} & \multirow[b]{2}{*}{ Average } \\
\hline$\#$ & Question & Answer & Comment & Answer & Comment & \\
\hline 1 & $\begin{array}{l}\text { Which community do you affiliate yourself } \\
\text { with? }\end{array}$ & Titoki & & Titoki & & \\
\hline 2 & $\begin{array}{l}\text { How long have you been a member in this } \\
\text { community? }\end{array}$ & Life & & Life & & \\
\hline 3 & $\begin{array}{l}\text { How did you become/are you affiliated with } \\
\text { this community? }\end{array}$ & Born in area & & Brought up in area & & \\
\hline 4 & $\begin{array}{l}\text { How often are you involved in your local } \\
\text { community life? }\end{array}$ & Weekly & Rugby Club, discussion groups & Monthly & Complex, Land care & \\
\hline 5 & $\begin{array}{l}\text { How often are you involved in the wider } \\
\text { community life (not necessarily where you } \\
\text { live)? }\end{array}$ & Bi-monthly & Complex dinner, pub & Annually & Land care. Political & \\
\hline 6 & $\begin{array}{l}\text { How actively involved in the community } \\
\text { would you say the residents of your local } \\
\text { community are in community life? }\end{array}$ & Mixed & Groups active, strong family links & Mixed & $\begin{array}{l}\text { Maori input in to area. Not much } \\
\text { goes on. Not like the old days. }\end{array}$ & \\
\hline 7 & $\begin{array}{l}\text { What services - public, community, private or } \\
\text { otherwise - would you say are lacking in your } \\
\text { community? }\end{array}$ & \multicolumn{2}{|c|}{ Petrol, otherwise well serviced } & \multicolumn{2}{|c|}{ A lot more could go on. Fire brigade } & \\
\hline 8 & $\begin{array}{l}\text { How would you rank the following } \\
\text { communities in terms of community spirit } \\
\text { levels? Maungakaramea }\end{array}$ & \multicolumn{2}{|l|}{1} & \multicolumn{2}{|l|}{2} & 1.384615385 \\
\hline & Maungatapere & \multicolumn{2}{|l|}{3} & \multicolumn{2}{|l|}{3} & 2.230769231 \\
\hline & Titoki & \multicolumn{2}{|l|}{2} & \multicolumn{2}{|l|}{1} & 2.333333333 \\
\hline 9 & $\begin{array}{l}\text { What attributes do you associate to the three } \\
\text { communities? Maungakaramea }\end{array}$ & \multicolumn{2}{|c|}{ Sports complex strong - supported } & \multicolumn{2}{|c|}{ Great community spirit } & \\
\hline & Maungatapere & \multicolumn{2}{|c|}{ Half town people - commuters } & \multicolumn{2}{|c|}{ Get along fairly well; hall bowling greens - too close to } & \\
\hline & Titoki & \multicolumn{2}{|c|}{ School central to valley. Going backwards in last generation } & \multicolumn{2}{|c|}{ Good community to live in. Not much to do in the area - easy } & \\
\hline 10 & Further comments & & & & & \\
\hline \multirow{4}{*}{ 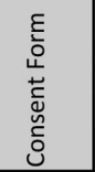 } & I would like to check my interview notes? & \multicolumn{2}{|l|}{$\mathrm{N}$} & \multicolumn{2}{|c|}{ N } & \\
\hline & Confidential/Identified & \multicolumn{2}{|c|}{ Identified - Andrew Booth; Share Milker } & \multicolumn{2}{|c|}{ Identified - Terry Gavin; Established Resident } & \\
\hline & Date & \multicolumn{2}{|l|}{ 11-Nov } & \multicolumn{2}{|l|}{ 11-Nov } & \\
\hline & Contact Address & \multicolumn{2}{|l|}{ N/A } & \multicolumn{2}{|l|}{ N/A } & \\
\hline
\end{tabular}


Appendix II: Deprivation 


\begin{tabular}{|c|c|c|c|c|c|c|c|c|c|c|c|}
\hline \multirow[b]{2}{*}{$\begin{array}{c}\text { Population } \\
\text { Statistics }\end{array}$} & \multicolumn{4}{|c|}{ Population } & \multicolumn{7}{|c|}{ Cultural Diversity } \\
\hline & Total & under 15 & $15-65$ & over 65 & European & Maori & $\begin{array}{l}\text { Pacific } \\
\text { People }\end{array}$ & Asian & \begin{tabular}{|c|} 
Middle \\
Eastern/ Latin \\
American/ \\
African
\end{tabular} & $\begin{array}{l}\text { Other } \\
\text { Ethnicity }\end{array}$ & $\begin{array}{l}\text { Born } \\
\text { overseas }\end{array}$ \\
\hline New Zealand & 4027947 & 21.5 & 66.2 & 12.3 & 67.6 & 14.65 & 6.9 & 9.2 & 0.9 & 11.2 & 22.9 \\
\hline Northland & 148470 & 23.4 & 62.1 & 14.5 & 68 & 31.7 & 2.7 & 1.9 & 0.3 & 10.7 & 14.2 \\
\hline $\begin{array}{l}\text { Titoki (Opouteke } \\
\text { Tanekaha) }\end{array}$ & 4485 & 26.9 & 65.4 & 7.7 & 73.8 & 20.1 & 1.3 & 1.1 & 0.1 & 14.9 & 11.2 \\
\hline Maungatapere & 1278 & 23.9 & 62.5 & 13.6 & 80.1 & 11.4 & 1.2 & 2.2 & 0.2 & 14.6 & 16.2 \\
\hline $\begin{array}{c}\text { Maungakaramea } \\
\text { (Wharekohe- } \\
\text { Oakleigh) }\end{array}$ & 3270 & 23 & 67.3 & 9.7 & 80.3 & 11.7 & 0.9 & 0.7 & 0.1 & 15.9 & 16.4 \\
\hline
\end{tabular}




\begin{tabular}{|c|c|c|c|c|c|c|c|}
\hline \multirow{2}{*}{$\begin{array}{c}\text { Population } \\
\text { Statistics }\end{array}$} & \multicolumn{3}{|c|}{ Martial Status } & \multicolumn{3}{|c|}{ Education } & \multirow{2}{*}{\begin{tabular}{|l} 
Work \\
$\begin{array}{l}\text { Unemploy } \\
\text { ment rate }\end{array}$
\end{tabular}} \\
\hline & Never Married & Married & $\begin{array}{l}\text { Seearated, } \\
\text { divorced or } \\
\text { widowed }\end{array}$ & $\begin{array}{l}\text { Post-school } \\
\text { Qualification }\end{array}$ & $\begin{array}{l}\text { School } \\
\text { Qualification }\end{array}$ & \begin{tabular}{|l} 
No Formaml \\
Qualification
\end{tabular} & \\
\hline New Zealand & 31.4 & 48.6 & 17.4 & 39.9 & 35.1 & 25 & 5.1 \\
\hline Northland & 29.8 & 49.8 & 20.5 & 35.3 & 32.8 & 31.9 & 6.5 \\
\hline $\begin{array}{l}\text { Titoki (Opouteke - } \\
\text { Tanekaha) }\end{array}$ & 28.2 & 60.1 & 11.6 & 38 & 34.2 & 27.8 & 4.6 \\
\hline Maungatapere & 20 & 64.3 & 16 & 42.8 & 35.5 & 21.7 & 3.2 \\
\hline $\begin{array}{l}\text { Maungakaramea } \\
\text { (Wharekohe- } \\
\text { Oakleigh) }\end{array}$ & 23.7 & 61.5 & 14.8 & 41.9 & 37 & 21.1 & 3 \\
\hline
\end{tabular}




\begin{tabular}{|c|c|c|c|c|c|c|c|c|c|}
\hline \multirow{2}{*}{$\begin{array}{c}\text { Population } \\
\text { Statistics }\end{array}$} & \multicolumn{3}{|c|}{ Income } & \multicolumn{3}{|c|}{ Families } & \multicolumn{3}{|c|}{ House- holds } \\
\hline & $\begin{array}{l}\text { Median } \\
\text { Income }\end{array}$ & $\begin{array}{c}\text { less than } \\
20,000\end{array}$ & $\begin{array}{c}\text { more than } \\
50,000\end{array}$ & $\begin{array}{l}\text { Couple } \\
\text { without child }\end{array}$ & $\begin{array}{l}\text { Couple with } \\
\text { Child }\end{array}$ & $\begin{array}{l}\text { One Parent } \\
\text { Family }\end{array}$ & $\begin{array}{l}\text { One-family } \\
\text { household }\end{array}$ & $\begin{array}{l}\text { One-person } \\
\text { household }\end{array}$ & $\begin{array}{l}\text { Average } \\
\text { household size }\end{array}$ \\
\hline New Zealand & 24,400 & 43.2 & 18 & 39.9 & 42 & 18.1 & 69.1 & 23 & 2.7 \\
\hline Northland & 20,900 & 48.4 & 13 & 42.3 & 37.3 & 20.4 & 70 & 24.1 & 2.6 \\
\hline $\begin{array}{l}\text { Titoki (Opouteke - } \\
\text { Tanekaha) }\end{array}$ & 26,500 & 39.2 & 20.5 & 38.5 & 50.9 & 10.7 & 81 & 13.6 & 3 \\
\hline Maungatapere & 26,300 & 39.2 & 21.2 & 44.6 & 46.3 & 9.9 & 81.4 & 14.3 & 2.8 \\
\hline $\begin{array}{l}\text { Maungakaramea } \\
\text { (Wharekohe- } \\
\text { Oakleigh) }\end{array}$ & 27,800 & 38.7 & 19.2 & 44.3 & 45 & 10.4 & 80.8 & 16.3 & 2.7 \\
\hline
\end{tabular}




\begin{tabular}{|c|c|c|c|c|c|c|c|}
\hline \multirow{2}{*}{$\begin{array}{l}\text { Population } \\
\text { Statistics }\end{array}$} & \multicolumn{5}{|c|}{ Access } & \multirow{2}{*}{\begin{tabular}{|l|} 
Transport \\
\\
Access to 3 or \\
more vehicles
\end{tabular}} & \multirow[t]{2}{*}{\begin{tabular}{|l} 
House \\
Ownership
\end{tabular}} \\
\hline & No access & Cellphone & Telephone & Fax machine & Internet & & \\
\hline New Zealand & 2 & 74.2 & 91.6 & 26 & 60.5 & 15.9 & 54.5 \\
\hline Northland & 3.5 & 70.8 & 87.1 & 27.6 & 51.8 & 14.5 & 56.7 \\
\hline $\begin{array}{l}\text { Titoki (Opouteke - } \\
\text { Tanekaha) }\end{array}$ & 2.2 & 82.1 & 93.2 & 40.5 & 65.9 & 25.6 & 61.4 \\
\hline Maungatapere & 0.7 & 82.4 & 96.3 & 39 & 69.1 & 25.5 & 60.3 \\
\hline $\begin{array}{l}\text { Maungakaramea } \\
\text { (Wharekohe- } \\
\text { Oakleigh) }\end{array}$ & 0.8 & 81.5 & 93.1 & 41.3 & 66.4 & 24.9 & 64.2 \\
\hline
\end{tabular}




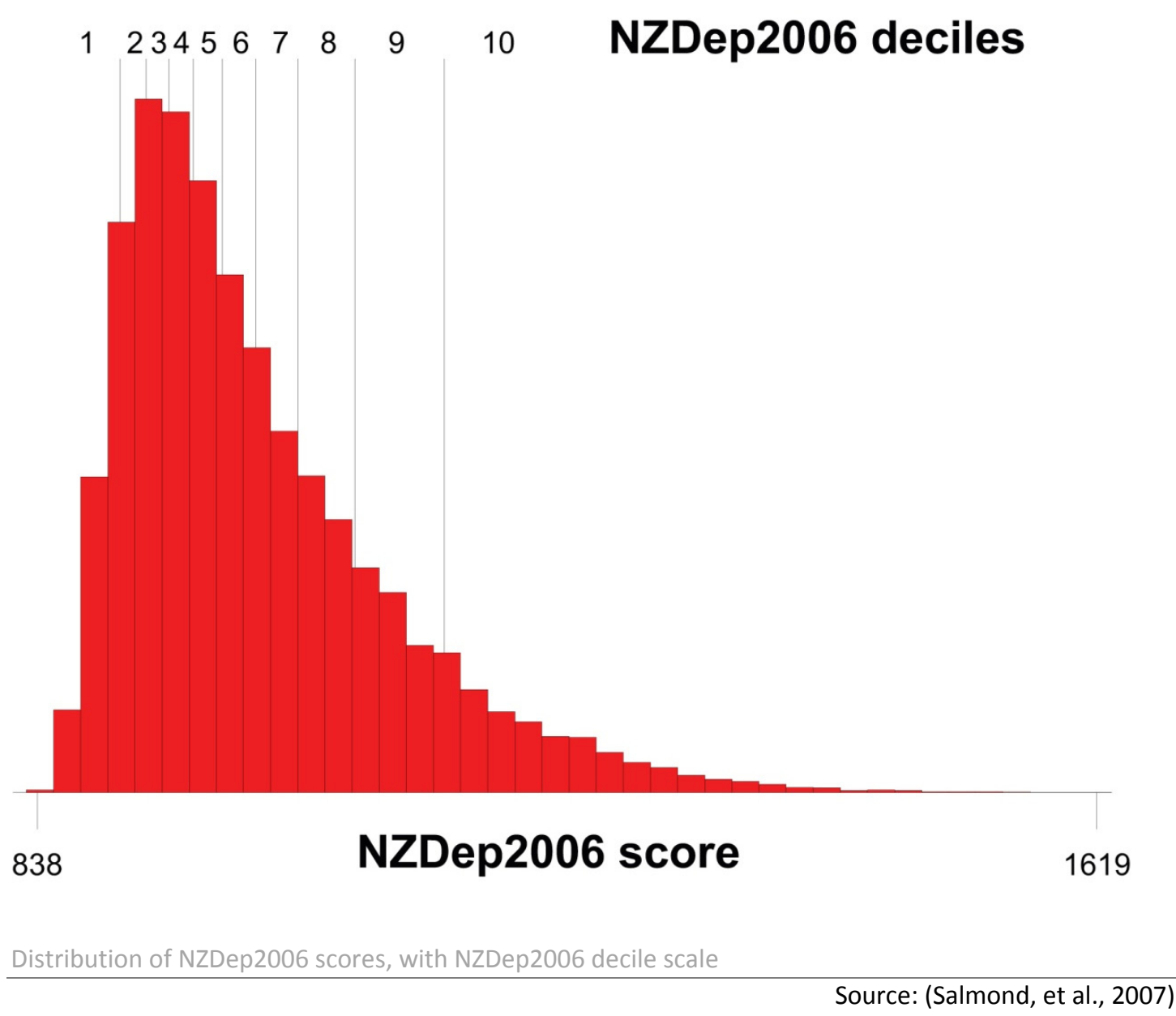


Appendix III: Services and Employment Opportunities 


\begin{tabular}{|c|c|c|c|c|c|c|}
\hline Business Category & Business Serving Titoki & Distance from Titoki & Business Serving Maungatapere & $\begin{array}{l}\text { Distance from } \\
\text { Maungatapere }\end{array}$ & Business Serving Maungakaramea & \begin{tabular}{|l|} 
Distance from \\
Maungakaramea
\end{tabular} \\
\hline Agricultural Consultant & & & Robinson Kir & Mobile & & \\
\hline Agricultural Contracting & & & Baume P W \& H M Contracting & Maungatapere & B \& H Whangarei Limited & $7.1 \mathrm{~km}$ \\
\hline Agricultural Contracting & & & & & Ray Lowe Contracting & $3.6 \mathrm{~km}$ \\
\hline Architectural Designer & & & Angela Bilyard-Smith Design & $2.5 \mathrm{~km}$ & & \\
\hline Architectural Designer & & & Dave Pope Design & $3.4 \mathrm{~km}$ & & \\
\hline Automotive Repairer & & & Maungatapere Automotive & $150 \mathrm{~m}$ & Maungakaramea Service Station & $1.4 \mathrm{~km}$ \\
\hline Business Consultants & & & & & Karamea Consulting Limited & $850 \mathrm{~m}$ \\
\hline Cafes & & & The Office Café & $50 \mathrm{~m}$ & & \\
\hline Carpet and Furniture Cleaning & & & Extreme Services & Maungatapere & & \\
\hline Cellular Phones & & & & & Installer Services Northland & $450 \mathrm{~m}$ \\
\hline Childcare and Education & Titoki Play centre & $200 \mathrm{~m}$ & Maungatapere Play centre & $200 \mathrm{~m}$ & Maungakaramea Play centre & $150 \mathrm{~m}$ \\
\hline Clothing Alterations and Repairs & & & Petals Dress Making & Maungatapere & & \\
\hline Commercial Venture & Gavin's Apiaries Limited & $1.5 \mathrm{~km}$ & & & & \\
\hline Draughting Services & & & Will Sumner Design Limitec & $4.5 \mathrm{~km}$ & & \\
\hline Drillers & & & Excel Drilling Limited & $1.5 \mathrm{~km}$ & & \\
\hline Earthmovers & & & D \& A Nisbet Contracting & $14.5 \mathrm{~km}$ & & \\
\hline Electricians & & & Electrix Limited & $1.6 \mathrm{~km}$ & & \\
\hline Electricians & & & Maungatapere Electrical Limited & Maungatapere & & \\
\hline Electricians & & & Trumper Electrical & $4.1 \mathrm{~km}$ & & \\
\hline Entertainment and Recreation & & & & & AE Fun park (paintball etc) & $4.5 \mathrm{~km}$ \\
\hline Explosives & & & & & Blasting Services & $6.5 \mathrm{~km}$ \\
\hline Garden Centres and Nurseries & & & Forest Floor Nursen! & $3.5 \mathrm{~km}$ & Tangihua Trees & Maungakaramea \\
\hline Garden Centres and Nurseries & & & Koromiko Nurserie: & $14 \mathrm{~km}$ & & \\
\hline Hotels and Taverns & & & Poroti Tavern & $7.6 \mathrm{~km}$ & & \\
\hline Logging Services & & & & & Cochrane \& Son Logging Limited & $5.2 \mathrm{~km}$ \\
\hline Painters and Paperhangers & & & & & Burns Karl Painters & Maungakaramea \\
\hline Photographers & & & Images Naturally & $850 \mathrm{~m}$ & & \\
\hline Rest and Convalescent Home & & & Mountain View Retirement Home & $130 \mathrm{~m}$ & Stonehaven Retirement Village & $300 \mathrm{~m}$ \\
\hline Roofing Contractors & & & Monier Bricks and Roofin£ & $14 \mathrm{~km}$ & & \\
\hline
\end{tabular}




\begin{tabular}{|c|c|c|c|c|c|c|}
\hline Business Category & Business Serving Titoki & Distance from Titoki & Business Serving Maungatapere & $\begin{array}{l}\text { Distance from } \\
\text { Maungatapere }\end{array}$ & Business Serving Maungakaramea & \begin{tabular}{|l} 
Distance from \\
Maungakaramea
\end{tabular} \\
\hline Schools & Mangakahia Area School & $50 \mathrm{~m}$ & Maungatapere Primary School & $160 \mathrm{~m}$ & Maungakaramea Primary School, & $240 \mathrm{~m}$ \\
\hline Schools & & & & & Tauraroa Area School & $3.9 \mathrm{~km}$ \\
\hline Service Stations & & & gas Maungatapere Dairy & $120 \mathrm{~m}$ & & \\
\hline Signs and sign writers & & & & & Mike Massey Sign Services & $7.3 \mathrm{~km}$ \\
\hline Sporting Facilities & Mangakahia Sports Complex & $8 \mathrm{~km}$ & Maungatapere Bowling Club & $1.2 \mathrm{~km}$ & Maungakaramea Bowling Club & $120 \mathrm{~m}$ \\
\hline Supermarkets & Titoki Store & $0 \mathrm{~m}$ & & & & \\
\hline Team Building Programs & & & Bushwacka Experience & $4.6 \mathrm{~km}$ & & \\
\hline Transport Contractors & & & Diesel \& Dirt Limited & $300 \mathrm{~m}$ & & \\
\hline Transport Operators & & & & & Mid-Western Transport Limited & $8.9 \mathrm{~km}$ \\
\hline Transport Operators & & & & & Semco Group Limited & Maungakaramea \\
\hline Weddings & & & Kiwi North & Maungatapere & & \\
\hline Weddings & & & The Country Yard & $2.3 \mathrm{~km}$ & & \\
\hline Weddings & & & The Rock-Hoppers Garder & $11 \mathrm{~km}$ & & \\
\hline Total Businesses Serving Communit & 5 & & 29 & & 18 & \\
\hline
\end{tabular}


Appendix IV: Rural Vernacular Architecture 


\subsection{Agricultural Farm Shed Data}

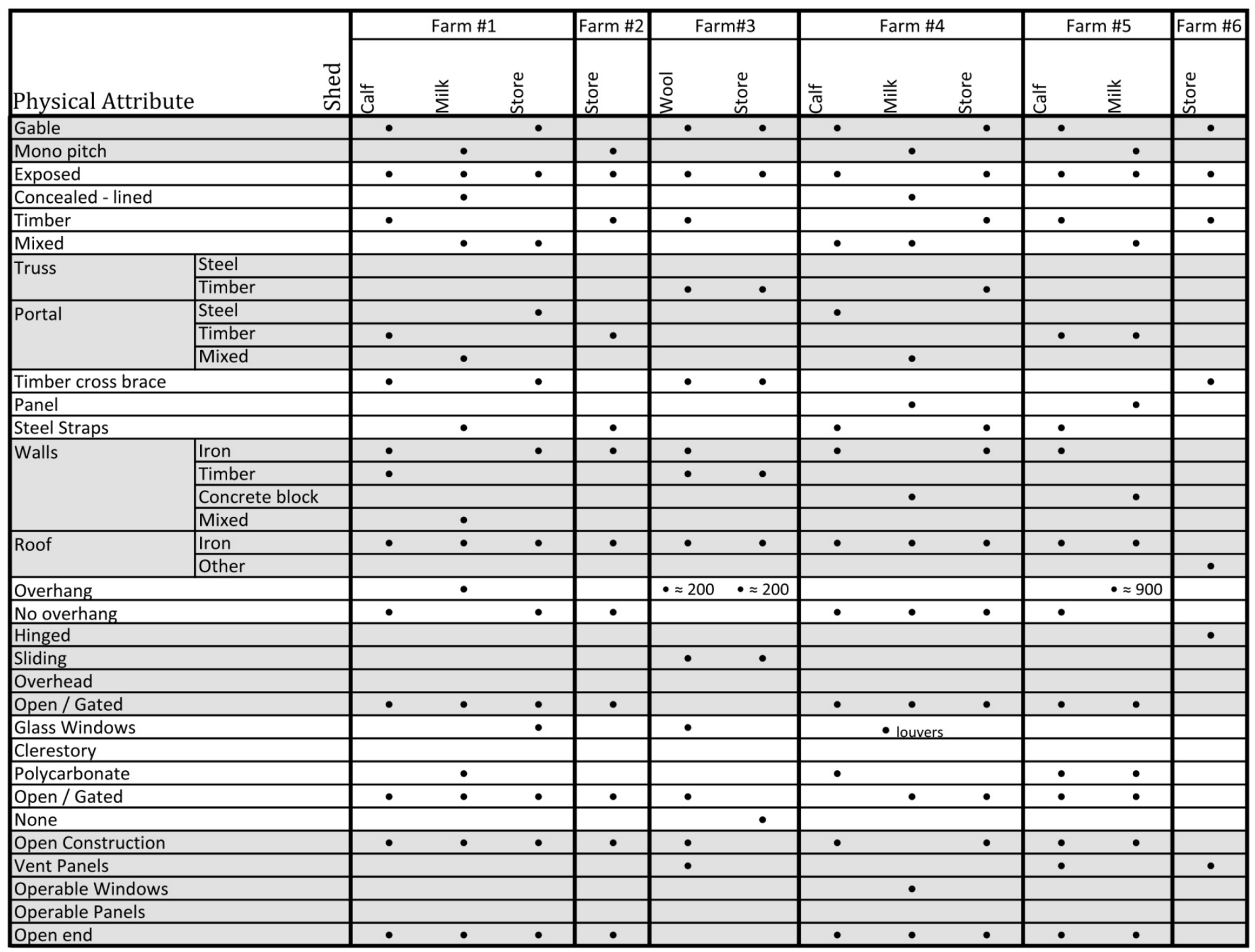



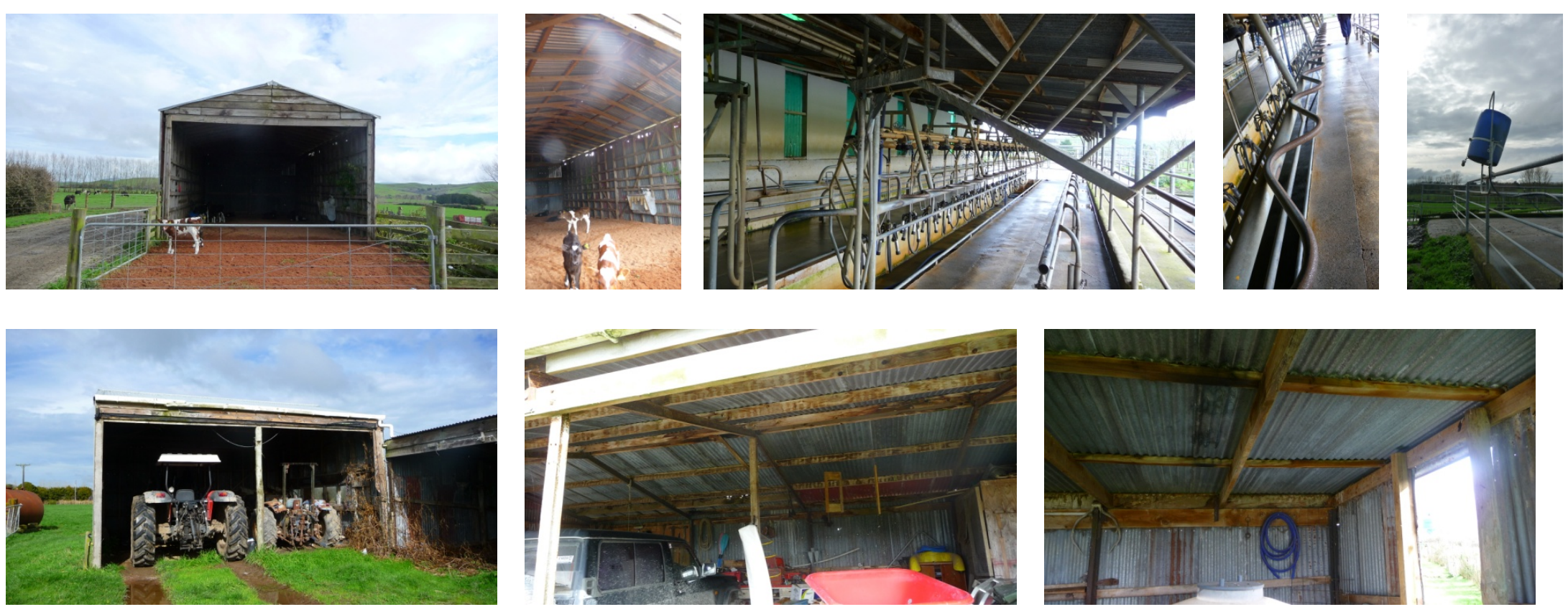

Farm \#2
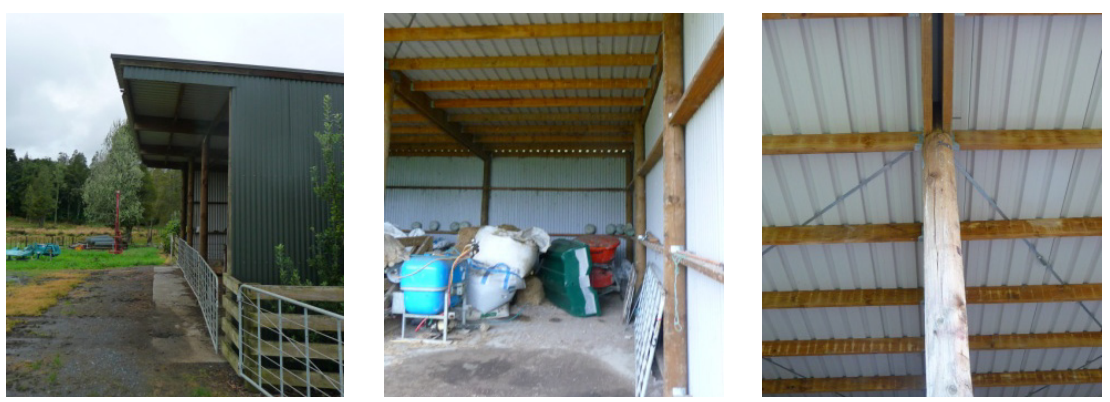

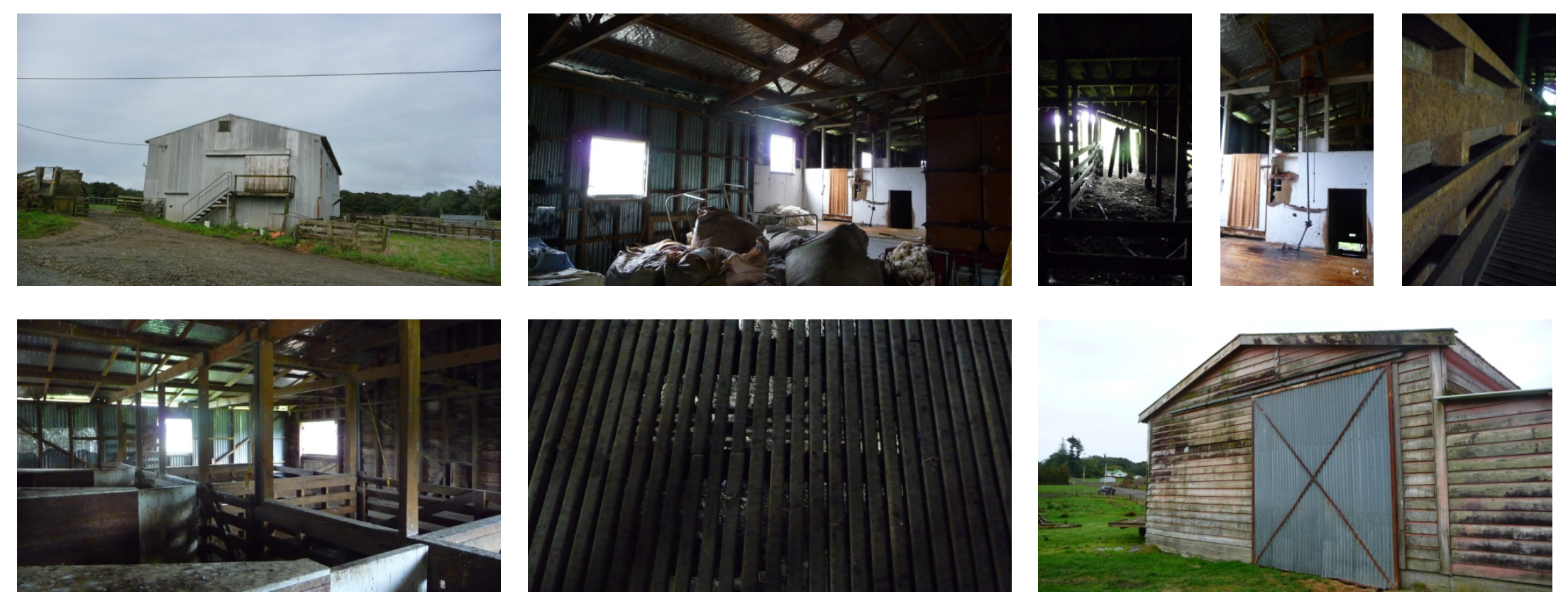

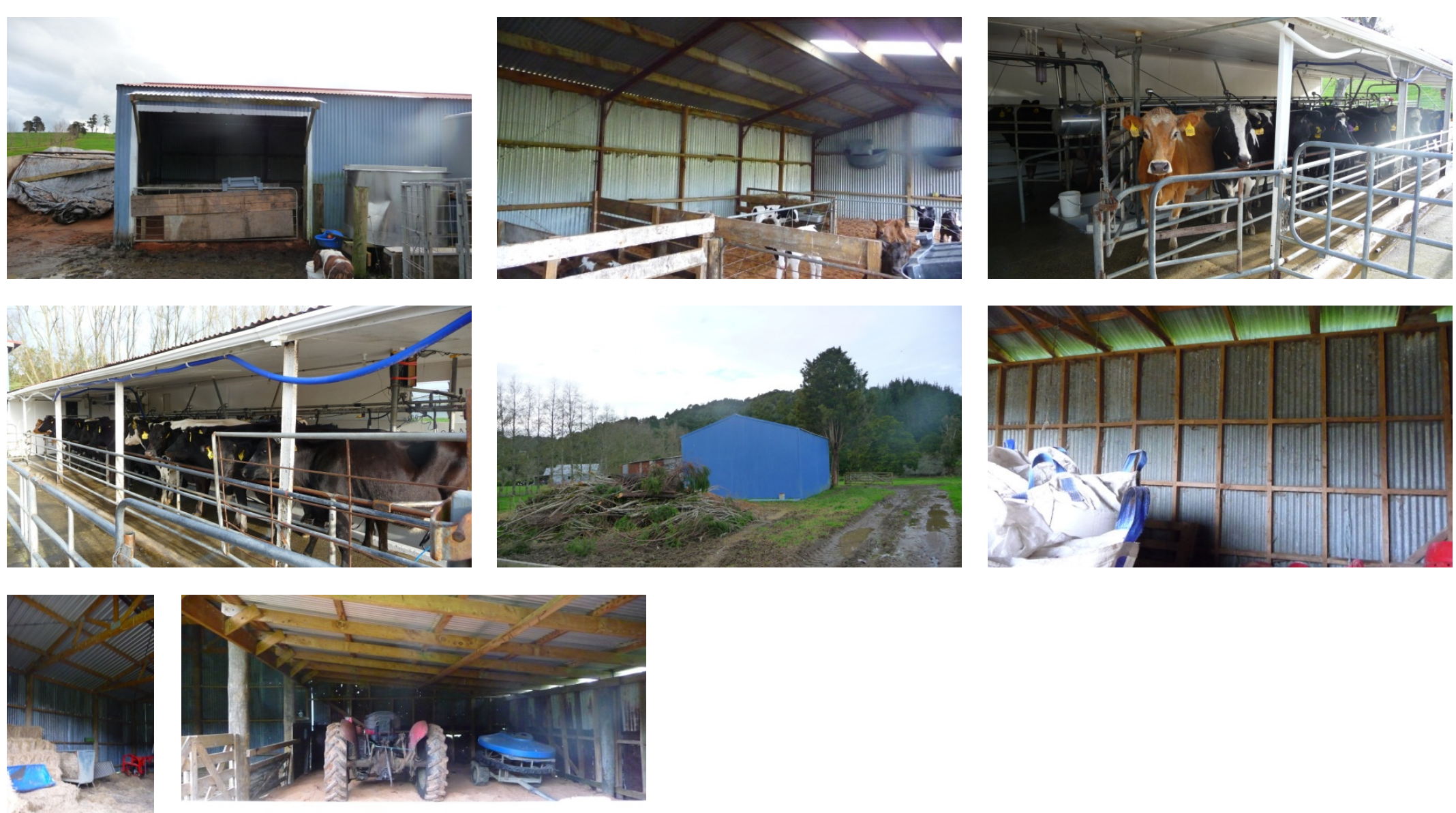

av 
Farm \#5

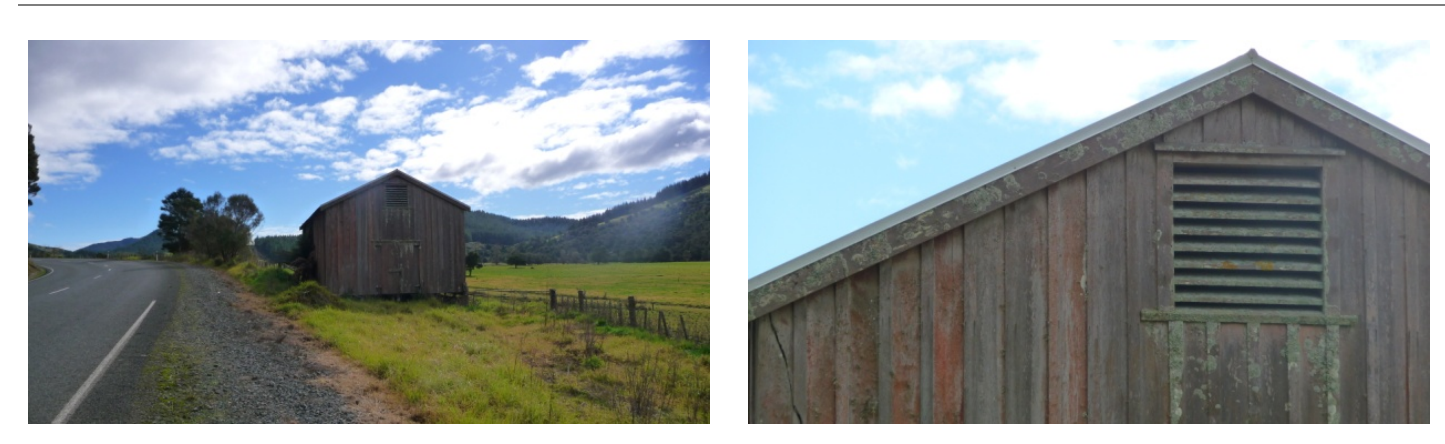


Appendix v: Community Hall Typology 
Empirical Research: Community Halls

Hall:

Location:

Site Size:

Estimated height to apex:

Overall external width:

Overall external depth:

Floor plan:
Date:

Age: 
North Elevation:

South Elevation:

West Elevation:

East Elevation: 
General

Description:

Construction Type:

Typical Use/s:

Annexed Facilities: 
Conditions Assessment:

Landscaping

Car parking

General Building Maintenance

- Roof

- Walls

-external

-internal

Paintwork

Street Presence/Relationship

Notice board

Disabled Access

Security

Signage 


\begin{tabular}{|c|c|c|c|c|c|c|c|c|c|c|c|c|}
\hline Hall & Ranking & Location & \begin{tabular}{|l} 
Community \\
Position
\end{tabular} & Site Area & \begin{tabular}{|l} 
Total Built \\
Area
\end{tabular} & $\begin{array}{l}\text { Proportion } \\
\text { Covered }\end{array}$ & \begin{tabular}{|l} 
Apex \\
Height
\end{tabular} & $\begin{array}{l}\begin{array}{l}\text { Hall } \\
\text { Width }\end{array} \\
\end{array}$ & \begin{tabular}{|l} 
Hall \\
Depth
\end{tabular} & Hall Area & $\begin{array}{l}\text { Roof } \\
\text { pitch }\end{array}$ & $\begin{array}{l}\text { Hall } \\
\text { Volume }\end{array}$ \\
\hline $\begin{array}{l}\text { Maungakaramea } \\
\text { Memorial Hall }\end{array}$ & & Pt Lot2 DP40435 & Central & 3520 & 408 & 0.115909091 & 7.5 & 12 & 30 & 360 & 35 & 1980 \\
\hline Kaurihohore Hall & 2 & \begin{tabular}{|l} 
Pt A LOT 34 PSH of \\
Whangarei DP23888
\end{tabular} & Peripheral & 834 & 233.38 & 0.279832134 & 7.1 & 9.3 & 18.3 & 170.19 & 30 & 987.102 \\
\hline Ruatangata Hall & 3 & A LOT 1915051782 & Central & 12639 & 355 & 0.028087665 & 4.8 & 10 & 24 & 240 & 20 & 936 \\
\hline $\begin{array}{l}\text { Kara/Kokopu } \\
\text { Community Hall }\end{array}$ & & DP 1561 & Central & 4036 & 154.63 & 0.038312686 & 7.6 & 8.7 & 12.5 & 108.75 & 40 & 630.75 \\
\hline Whatitiri Hall & & $\begin{array}{l}\text { Section } 23 \text { BIk XIV } \\
\text { Purua SD SO41073 }\end{array}$ & Central & 18884 & 162.96 & 0.008629528 & 6.25 & 7.2 & 16.8 & 120.96 & 32 & 619.92 \\
\hline Mangapai Hall & & $\begin{array}{l}\text { Pt A LOT 3 PSH of } \\
\text { Mangapai SO6155 }\end{array}$ & Central & 3622 & 248.5 & 0.068608504 & 6.64 & 7 & 21.5 & 150.5 & 40 & 801.413 \\
\hline Whakapara Hall & 7 & DP14982 & Peripheral & 1224 & 226.48 & 0.18503268 & 7.3 & 9.2 & 18.3 & 168.36 & 28.5 & 1018.58 \\
\hline Waiotira Hall & 8 & Lot 42 DP14912 & Central & 1430 & 225 & 0.157342657 & 5.5 & 8.5 & 18 & 153 & 20 & 726.75 \\
\hline Mata Hall & 9 & DP 4344 & Isolated & 7966 & 162 & 0.02033643 & 7 & 9 & 15 & 135 & 35 & 742.5 \\
\hline Otaika Hall & 10 & $\begin{array}{l}\text { Pt A LOT } 135 \\
\text { SO34045 }\end{array}$ & Central & 1647 & 253 & 0.153612629 & 7 & 11 & 16 & 176 & 30 & 968 \\
\hline Parakao Hall & 11 & $\begin{array}{l}\text { Pt Section } 5 \text { Blk } \\
\text { DP20974 }\end{array}$ & Central & 4686 & 282.5 & 0.060285958 & 8.3 & 10 & 18 & 180 & 30 & 1242 \\
\hline Marua Hall & 12 & Section 44 SO 42535 & Isolated & 20293 & 260.36 & 0.01283004 & 6.3 & 9.3 & 20 & 186 & 30 & 911.4 \\
\hline Purua Hall & 13 & $\begin{array}{l}\text { Section } 96 \text { Blk I SD } \\
20593\end{array}$ & Isolated & 5022 & 168 & $\begin{array}{l}3 \\
0.033452808\end{array}$ & 8 & 9 & 16 & 144 & 40 & 900 \\
\hline Portland Hall & 14 & Lot1 DP207346 & |Peripheral & 93715 & 473 & 0.005047218 & 9.5 & 12 & 30 & 360 & 35 & 2700 \\
\hline Maungatapere Hall & 15 & $\begin{array}{l}\text { Muangatapere } \\
\text { DP10945 }\end{array}$ & Peripheral & 6927 & 310 & 0.044752418 & 9 & 9 & 17 & 153 & 40 & 1370.25 \\
\hline MEDIAN & & & & 4854 & 237.49 & 0.041532552 & 7.15 & 9 & 17.5 & 153 & 33.5 & 905.7 \\
\hline AVERAGE & & & & 14121 & 243.8691667 & 0.065686963 & 7.36583 & 9.15833 & 18.2583 & 169.631 & 33.375 & 1052.63 \\
\hline
\end{tabular}




\begin{tabular}{|c|c|c|c|c|c|c|c|c|c|c|c|c|}
\hline Top Five Halls & Ranking & Location & \begin{tabular}{|l} 
Community \\
Position
\end{tabular} & Site Area & $\begin{array}{l}\text { Total Built } \\
\text { Area }\end{array}$ & $\begin{array}{l}\text { Proportion } \\
\text { Covered }\end{array}$ & $\begin{array}{l}\text { Apex } \\
\text { Height }\end{array}$ & $\begin{array}{l}\text { Hall } \\
\text { Width }\end{array}$ & $\begin{array}{l}\text { Hall } \\
\text { Depth }\end{array}$ & Hall Area & $\begin{array}{l}\text { Roof } \\
\text { pitch }\end{array}$ & $\begin{array}{l}\text { Hall } \\
\text { Volume }\end{array}$ \\
\hline $\begin{array}{l}\text { Maungakaramea } \\
\text { Memorial Hall }\end{array}$ & 1 & Pt Lot2 DP40435 & Central & 3520 & 408 & 0.115909091 & 7.5 & 12 & 30 & 360 & 35 & 1980 \\
\hline Kaurihohore Hall & 2 & $\begin{array}{l}\text { Pt A LOT } 34 \text { PSH of } \\
\text { Whangarei DP23880 }\end{array}$ & Peripheral & 834 & 233.38 & 0.279832134 & 7.1 & 9.3 & 18.3 & 170.19 & 30 & 987.102 \\
\hline Ruatangata Hall & 3 & A LOT 191 SO51782 & Central & 12639 & 355 & 0.028087665 & 4.8 & 10 & 24 & 240 & 20 & 936 \\
\hline $\begin{array}{l}\text { Kara/Kokopu } \\
\text { Community Hall }\end{array}$ & 4 & DP 1561 & Central & 4036 & 154.63 & 0.038312686 & 7.6 & 8.7 & 12.5 & 108.75 & 40 & 630.75 \\
\hline Whatitiri Hall & & $\begin{array}{l}\text { Section } 23 \text { Blk XIV } \\
\text { Purua SD SO41073 }\end{array}$ & Central & 18884 & 162.96 & 0.008629528 & 6.25 & 7.2 & 16.8 & 120.96 & 32 & 619.92 \\
\hline MEDIAN & & & & 4036 & 233.38 & 0.038312686 & 7.1 & 9.3 & 18.3 & 170.19 & 32 & 936 \\
\hline AVERAGE & & & & 7982.6 & 262.794 & 0.094154221 & 6.65 & 9.44 & 20.32 & 199.98 & 31.4 & 1030.75 \\
\hline \multirow{2}{*}{\multicolumn{3}{|c|}{ Titoki Comparable Median }} & & 4036 & 162.96 & 0.038312686 & 7.1 & 8.7 & 16.8 & 120.96 & 32 & 630.75 \\
\hline & & & & 7918 & 183.6566667 & 0.108924783 & 6.98333 & 8.4 & 15.8667 & 133.3 & 34 & 745.924 \\
\hline
\end{tabular}

\begin{tabular}{|c|c|c|c|c|c|c|c|c|c|c|c|c|}
\hline Bottom Five Halls & Ranking & Location & $\begin{array}{l}\text { Community } \\
\text { Position }\end{array}$ & Site Area & $\begin{array}{l}\text { Total Built } \\
\text { Area }\end{array}$ & $\begin{array}{l}\text { Proportion } \\
\text { Covered }\end{array}$ & $\begin{array}{l}\text { Apex } \\
\text { Height }\end{array}$ & $\begin{array}{l}\text { Hall } \\
\text { Width }\end{array}$ & $\begin{array}{l}\text { Hall } \\
\text { Depth }\end{array}$ & Hall Area & $\begin{array}{l}\text { Roof } \\
\text { pitch }\end{array}$ & $\begin{array}{l}\text { Hall } \\
\text { Volume }\end{array}$ \\
\hline Parakao Hall & 11 & $\begin{array}{l}\text { Pt Section } 5 \text { Blk } \\
\text { DP20974 }\end{array}$ & Central & 4686 & 282.5 & 0.060285958 & 8.3 & 10 & 18 & 180 & 30 & 1242 \\
\hline Marua Hall & 12 & Section 44 SO 42535 & Isolated & 20293 & 260.36 & 0.01283004 & 6.3 & 9.3 & 20 & 186 & 30 & 911.4 \\
\hline Purua Hall & 13 & $\begin{array}{l}\text { Section } 96 \text { Blk I SD } \\
20593\end{array}$ & Isolated & 5022 & 168 & 0.033452808 & 8 & 9 & 16 & 144 & 40 & 900 \\
\hline Portland Hall & 14 & Lot1 DP207346 & Peripheral & 93715 & 473 & 0.005047218 & 9.5 & 12 & 30 & 360 & 35 & 2700 \\
\hline Maungatapere Hall & 15 & $\begin{array}{l}\text { Muangatapere } \\
\text { DP10945 }\end{array}$ & Peripheral & 6927 & 310 & 0.044752418 & 9 & 9 & 17 & 153 & 40 & 1370.25 \\
\hline MEDIAN & & & & 6927 & 282.5 & 0.033452808 & 8.3 & 9.3 & 18 & 180 & 35 & 1242 \\
\hline AVERAGE & & & & 26128.6 & 298.772 & 0.031273688 & 8.22 & 9.86 & 20.2 & 204.6 & 35 & 1424.73 \\
\hline
\end{tabular}




\begin{tabular}{|c|c|c|c|c|c|c|c|}
\hline Hall & 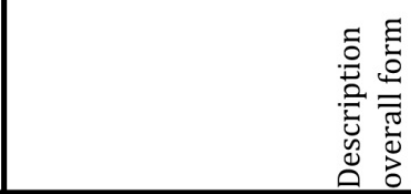 & 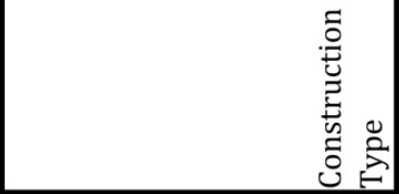 & 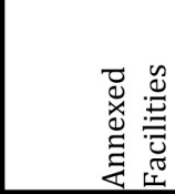 & 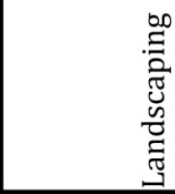 & 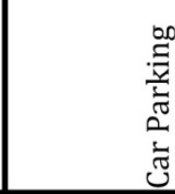 & 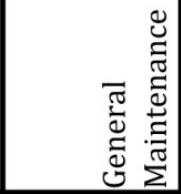 & 岁 \\
\hline $\begin{array}{c}\text { Maungakaramea } \\
\text { Memorial Hall }\end{array}$ & $\begin{array}{l}\text { Simple form with articulated } \\
\text { entrance; Mobile Library Bus Stop; } \\
\text { Zumba classes; v. tidy; small kitchen } \\
\text { \& toilets compared to hall; easily } \\
\text { recognisable; outdoor area w picnic } \\
\text { tables; local purpose reserve }\end{array}$ & $\begin{array}{l}\text { Rough cast plaster with } \\
\text { weatherboards to gable ends; } \\
\text { Aluminium joinery; polished timber } \\
\text { floors }\end{array}$ & $\begin{array}{l}\text { Close to play } \\
\text { centre, sports } \\
\text { clubs, church, } \\
\text { schools }\end{array}$ & $\begin{array}{l}\text { Mowed grass } \\
\text { area as } \\
\text { overflow } \\
\text { parking }\end{array}$ & $\begin{array}{l}\text { In front of hall; } \\
\text { loose chip } \\
\text { surface; } \\
\text { overflow onto } \\
\text { grassed area, } \\
\text { side of road }\end{array}$ & \begin{tabular}{|l|} 
very tidy \\
condition of \\
hall and \\
grounds
\end{tabular} & $\begin{array}{l}\text { Corrugated } \\
\text { long run iron } \\
\text { painted green } \\
\text { - no sign of } \\
\text { mould or rust }\end{array}$ \\
\hline Kaurihohore Hall & $\begin{array}{l}\text { Simple form hall with articulated } \\
\text { entrance - miniature of hall and lean- } \\
\text { to kitchen/toilet block; very tidy } \\
\text { weatherboard building; sits up } \\
\text { above road; rain water collection }\end{array}$ & $\begin{array}{l}\text { 200deep rusticated timber } \\
\text { weather boards; short run painted } \\
\text { corrugated iron; wooden window } \\
\text { surrounds with aluminium inserts; } \\
\text { polished timber floors; metal ties } \\
\text { in roof exposed }\end{array}$ & - & $\begin{array}{l}\text { Very little } \\
\text { landscaping; } \\
\text { main hall in } \\
\text { paddock and } \\
\text { grazed; grass } \\
\text { growing } \\
\text { through } \\
\text { metalled area; } \\
\text { concrete path }\end{array}$ & $\begin{array}{l}\text { Metal area } \\
\text { with duel } \\
\text { entrance; } \\
\text { limited } \\
\text { parking; } \\
\text { overflow up } \\
\text { the road verge } \\
\text { and into } \\
\text { paddock }\end{array}$ & $\begin{array}{l}\text { Very tidy } \\
\text { condition of } \\
\text { hall, well cared } \\
\text { for, new sign } \\
\text { etc }\end{array}$ & $\begin{array}{l}\text { Short run } \\
\text { painted } \\
\text { corrugated } \\
\text { iron in } \\
\text { reasonable } \\
\text { condition }\end{array}$ \\
\hline $\begin{array}{l}\text { Ruatangata } \\
\text { District Hall }\end{array}$ & $\begin{array}{l}\text { Newest building of all sampled; } \\
\text { entrance articulated to the street; } \\
\text { parking area inaccessible to public; } \\
\text { tidy construction and well looked } \\
\text { after building; main hall with two } \\
\text { extensions to } \\
\text { entrance/kitchen/toilets and stage; } \\
\text { roof line continuous for hall section } \\
\text { and entrance different }\end{array}$ & $\begin{array}{l}\text { Concrete block construction of } \\
\text { original and extensions; corrugated } \\
\text { colour steel; timber joinery to hall, } \\
\text { aluminium joinery to entrance } \\
\text { extension }\end{array}$ & Tennis Courts & $\begin{array}{l}\text { Planter boxes } \\
\text { to sides of } \\
\text { entrance steps; } \\
\text { main body of } \\
\text { hall is in } \\
\text { paddock }\end{array}$ & $\begin{array}{l}\text { Off-street, in } \\
\text { front of } \\
\text { building and } \\
\text { shared with } \\
\text { tennis courts; } \\
\text { sealed with } \\
\text { grass growing } \\
\text { through in } \\
\text { patches }\end{array}$ & \begin{tabular}{|l} 
Tidy street \\
presence in the \\
area; easy \\
maintenance \\
due to \\
construction
\end{tabular} & $\begin{array}{l}\text { Corrugated } \\
\text { colour steel } \\
\text { iron in } \\
\text { excellent } \\
\text { condition; } \\
\text { spouting and } \\
\text { fascia boards } \\
\text { with some } \\
\text { mould }\end{array}$ \\
\hline
\end{tabular}




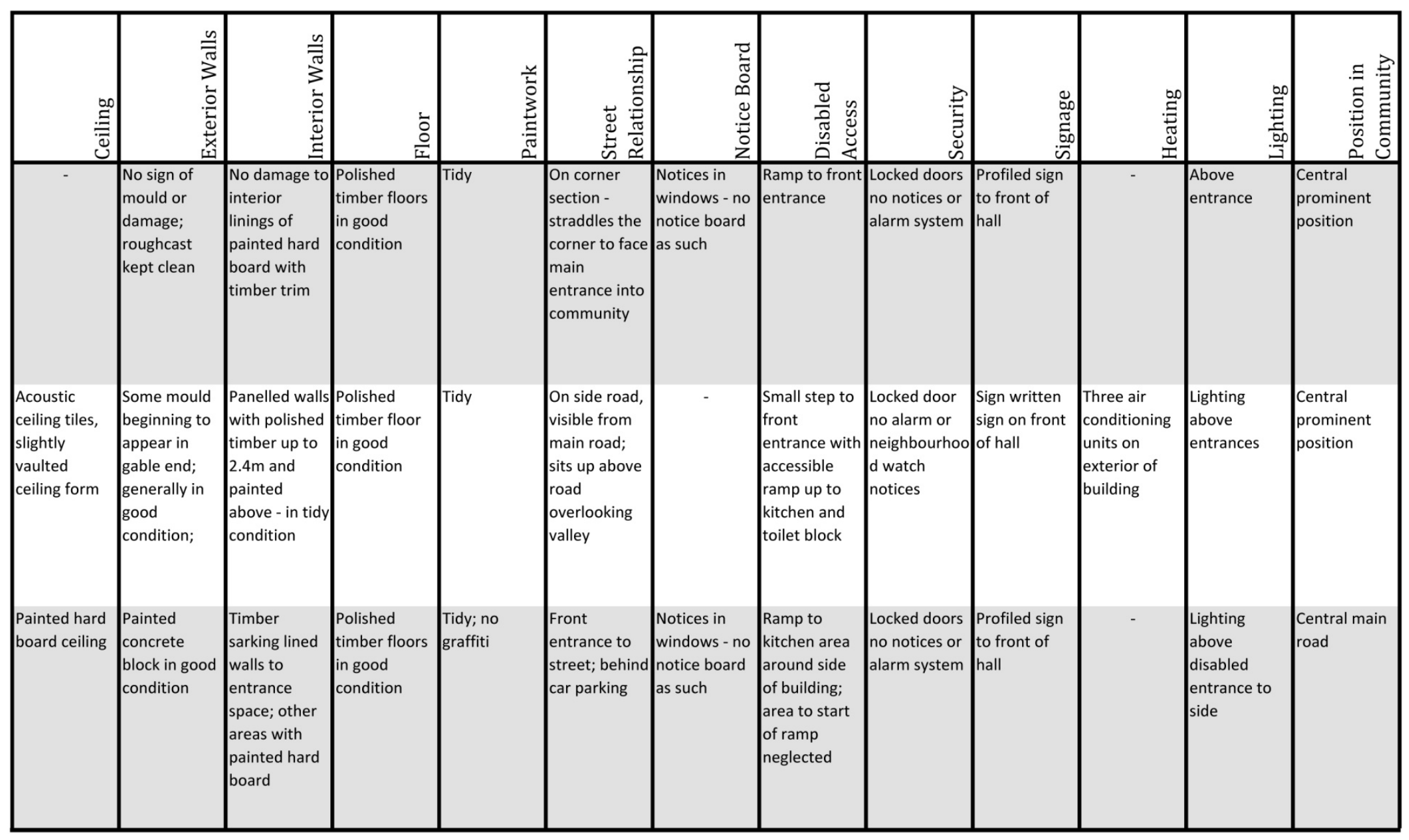




\begin{tabular}{|c|c|c|c|c|c|c|c|}
\hline Hall & 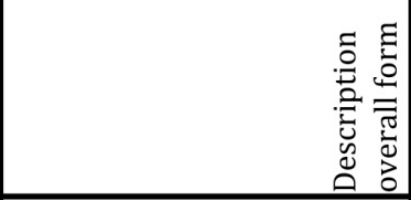 & 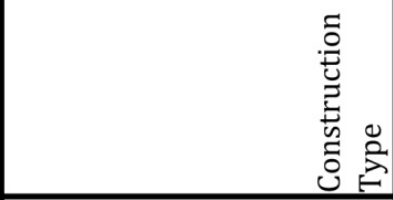 & 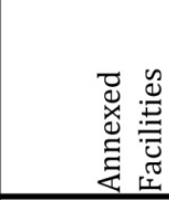 & 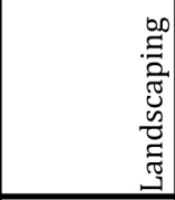 & 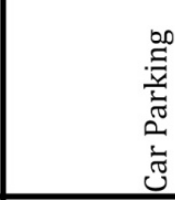 & ت & 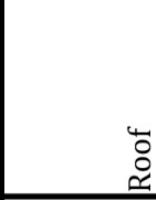 \\
\hline $\begin{array}{l}\text { Kara/Kokopu } \\
\text { Community Hall }\end{array}$ & $\begin{array}{l}\text { Old Kaitara School site and building; } \\
\text { Entranceway covered and } \\
\text { articulated; Main hall symmetric; } \\
\text { Recently extended with toilet blocks } \\
\text { out back }\end{array}$ & $\begin{array}{l}\text { Rough sawn bevel-back } \\
\text { weatherboards; Corrugated iron } \\
\text { roof; Polished timber floors; } \\
\text { Interior-mixture timber sarking \& } \\
\text { plasterboard; Tile ceiling }\end{array}$ & - & $\begin{array}{l}\text { Mowed grass } \\
\text { area with } \\
\text { established } \\
\text { tree; no } \\
\text { landscaping as } \\
\text { such }\end{array}$ & $\begin{array}{l}\text { Metalled drive; } \\
\text { limited parking } \\
\text { on metal with } \\
\text { grass growing } \\
\text { through; } \\
\text { overflow onto } \\
\text { grass area }\end{array}$ & $\begin{array}{l}\text { Building } \\
\text { appears well } \\
\text { looked after }\end{array}$ & $\begin{array}{l}\text { Galvanised } \\
\text { steel to } \\
\text { additions; } \\
\text { painted } \\
\text { elsewhere }\end{array}$ \\
\hline Whatitiri Hall & $\begin{array}{l}\text { Recreation Reserve - Whatitiri } \\
\text { Domain; old school building; simple } \\
\text { form of gable ends with lean-to } \\
\text { extension of one roof line; public } \\
\text { toilet and internal toilet; rain water } \\
\text { collection; in bush setting }\end{array}$ & $\begin{array}{l}180 \text { bevel back timber weather } \\
\text { boards; corrugated iron roof; sash } \\
\text { and cabinet wooden windows - all } \\
\text { above external viewing }\end{array}$ & Tennis Courts & $\begin{array}{l}\text { Established } \\
\text { native trees in } \\
\text { hall boundary; } \\
\text { plantings at } \\
\text { entrance - } \\
\text { 10years; easy } \\
\text { care landscape } \\
\text { basic }\end{array}$ & $\begin{array}{l}\text { Roadsides } \\
\text { metalled and } \\
\text { widened to } \\
\text { accommodate } \\
\text { parking - } \\
\text { limited }\end{array}$ & $\begin{array}{l}\text { Building } \\
\text { appears tidy } \\
\text { and major } \\
\text { works going on } \\
\text { with tennis } \\
\text { courts } \\
\text { suggesting } \\
\text { renewed } \\
\text { interest }\end{array}$ & $\begin{array}{l}\text { Long run iron } \\
\text { on half of } \\
\text { roof, other } \\
\text { half starting } \\
\text { to mould and } \\
\text { rust; }\end{array}$ \\
\hline Mangapai Hall & $\begin{array}{l}\text { Simple form hall with additional lean } \\
\text { to annexes to either side of entrance } \\
\text { housing kitchen and toilet facilities; } \\
\text { storage space below in sub entrance } \\
\text { level; town water supply; Mobile } \\
\text { Library Bus Stop; Neighbourhood } \\
\text { watch presence; bus stop shelter to } \\
\text { street }\end{array}$ & $\begin{array}{l}\text { Rough sawn bevel back timber } \\
\text { weather boards } 220 \text {, fibre cement } \\
\text { and rusticated weatherboards; } \\
\text { long run corrugated iron roof; } \\
\text { wooden windows to main hall, } \\
\text { aluminium to annexes. }\end{array}$ & $\begin{array}{l}\text { Play centre } \\
\text { next door }\end{array}$ & $\begin{array}{l}\text { No plantings, } \\
\text { mowed } \\
\text { grassed area }\end{array}$ & $\begin{array}{l}\text { Very limited } \\
\text { parking } \\
\text { although on a } \\
\text { quiet street }\end{array}$ & $\begin{array}{l}\text { Tidy condition } \\
\text { of exterior; } \\
\text { storage area } \\
\text { looks messy } \\
\text { and uncared } \\
\text { for; internally } \\
\text { upstairs } \\
\text { appears clean }\end{array}$ & $\begin{array}{l}\text { Mould on } \\
\text { roof and } \\
\text { spouting; } \\
\text { spouting } \\
\text { beginning to } \\
\text { droop in } \\
\text { places - grass } \\
\text { growing }\end{array}$ \\
\hline
\end{tabular}




\begin{tabular}{|c|c|c|c|c|c|c|c|c|c|c|c|c|}
\hline$\stackrel{0}{:}$ & 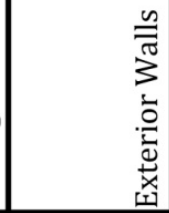 & 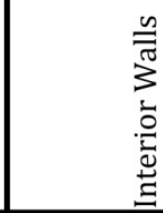 & $\frac{\dot{0}}{\frac{0}{I}}$ & . & 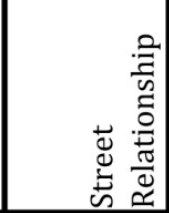 & $\begin{array}{l}0 \\
0 \\
0 \\
0 \\
0 \\
.0 .0 \\
0 \\
z\end{array}$ & 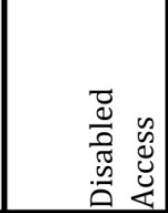 & 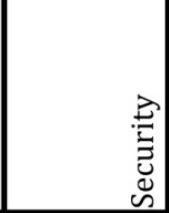 & 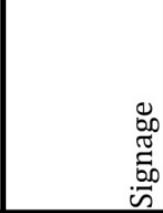 & 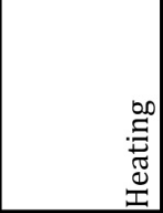 & 苛 & 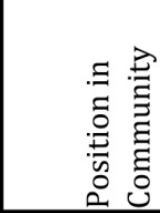 \\
\hline $\begin{array}{l}\text { Flat tiled } \\
\text { ceiling at } \\
3.5 \mathrm{~m} \text { with } \\
\text { ceiling fans }\end{array}$ & $\begin{array}{l}3 / 4 \text { freshly } \\
\text { painted; in } \\
\text { need of } \\
\text { sanding back } \\
\text { and painting }\end{array}$ & $\begin{array}{l}\text { Freshly } \\
\text { painted and } \\
\text { damage free }\end{array}$ & \begin{tabular}{|l} 
Polished \\
timber floors
\end{tabular} & $\begin{array}{l}3 / 4 \text { painted; } \\
\text { bubbled and } \\
\text { chipped paint } \\
\text { painted over }\end{array}$ & \begin{tabular}{|l|} 
Set back in \\
paddock - \\
removed \\
from the road
\end{tabular} & $\begin{array}{l}\text { In the open } \\
\text { foyer area - } \\
\text { public } \\
\text { accessible }\end{array}$ & $\begin{array}{l}\text { No disabled } \\
\text { access }\end{array}$ & $\begin{array}{l}\text { Locked door; } \\
\text { cleaning } \\
\text { bucket left } \\
\text { out; building } \\
\text { work is } \\
\text { secure }\end{array}$ & $\begin{array}{l}\text { Roadside sign } \\
\text { and sign on } \\
\text { front of hall }\end{array}$ & $\begin{array}{l}\text { In the form of } \\
\text { wall mounted } \\
\text { electric } \\
\text { heaters }\end{array}$ & \begin{tabular}{|l|} 
External \\
lighting \\
switch to \\
exterior, \\
internal \\
lighting \\
simple down \\
lights from \\
ceiling.
\end{tabular} & $\begin{array}{l}\text { Central main } \\
\text { road }\end{array}$ \\
\hline $\begin{array}{l}\text { Hard board } \\
\text { flat ceiling } \\
\text { painted }\end{array}$ & $\begin{array}{l}\text { Spiders; some } \\
\text { boards are } \\
\text { beginning to } \\
\text { sag; evidence } \\
\text { of dirt and } \\
\text { plant life } \\
\text { growing up } \\
\text { walls } \\
\text { removed }\end{array}$ & $\begin{array}{l}\text { Beginning to } \\
\text { tire }\end{array}$ & $\begin{array}{l}\text { Polished } \\
\text { timber floors }\end{array}$ & $\begin{array}{l}\text { Reasonable, } \\
\text { all appears } \\
\text { done at once, } \\
\text { perhaps a few } \\
\text { years back }\end{array}$ & $\begin{array}{l}\text { Set back from } \\
\text { road in } \\
\text { landscaping, } \\
\text { no parking } \\
\text { directly out } \\
\text { front }\end{array}$ & - & $\begin{array}{l}\text { Accessible } \\
\text { ramp to main } \\
\text { entrance }\end{array}$ & $\begin{array}{l}\text { Locked doors } \\
\text { and alarm } \\
\text { system }\end{array}$ & $\begin{array}{l}\text { Sign on } \\
\text { roadside with } \\
\text { next function } \\
\text { slot }\end{array}$ & No heating & $\begin{array}{l}\text { Security } \\
\text { lighting on } \\
\text { corner of } \\
\text { building - } \\
\text { none at } \\
\text { entrance } \\
\text { door }\end{array}$ & $\begin{array}{l}\text { Central side } \\
\text { road }\end{array}$ \\
\hline $\begin{array}{l}\text { Metal roof } \\
\text { ties with soft } \\
\text { board } \\
\text { panelled } \\
\text { slightly } \\
\text { vaulted roof } \\
\text { cavity }\end{array}$ & $\begin{array}{l}\text { Tidily painted, } \\
\text { some } \\
\text { discontinuati } \\
\text { on in } \\
\text { materials }\end{array}$ & $\begin{array}{l}\text { Hard board } \\
\text { panels } \\
\text { painted - } \\
\text { appears } \\
\text { damage free; } \\
\text { stage area } \\
\text { walls vertical } \\
\text { sarking }\end{array}$ & $\begin{array}{l}\text { Light polished } \\
\text { timber floors }\end{array}$ & $\begin{array}{l}\text { Tidy and } \\
\text { reasonably } \\
\text { fresh }\end{array}$ & $\begin{array}{l}\text { On side road; } \\
\text { faces towards } \\
\text { the on } \\
\text { coming traffic } \\
\text { from the } \\
\text { main road }\end{array}$ & $\begin{array}{l}\text { Notices in } \\
\text { windows - no } \\
\text { notice board } \\
\text { as such }\end{array}$ & $\begin{array}{l}\text { Ramp to front } \\
\text { door } \\
\text { accessible; } \\
\text { steep ramp to } \\
\text { stage side } \\
\text { entrance; } \\
\text { disabled } \\
\text { toilets inside }\end{array}$ & $\begin{array}{l}\text { Locked door; } \\
\text { neighbourhoo } \\
\text { d support } \\
\text { signage on } \\
\text { exterior } \\
\end{array}$ & $\begin{array}{l}\text { Sign written } \\
\text { sign on front } \\
\text { of hall }\end{array}$ & No heating & $\begin{array}{l}\text { Lighting } \\
\text { above } \\
\text { entrance to } \\
\text { hall }\end{array}$ & $\begin{array}{l}\text { Central side } \\
\text { road }\end{array}$ \\
\hline
\end{tabular}




\begin{tabular}{|c|c|c|c|c|c|c|c|}
\hline Hall & 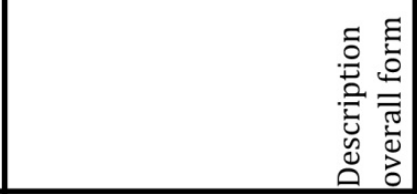 & 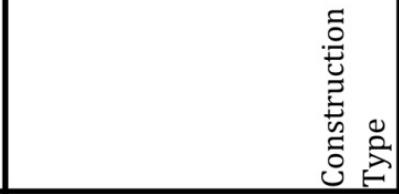 & 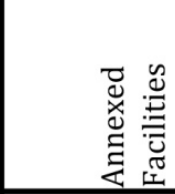 & 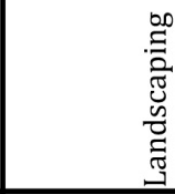 & 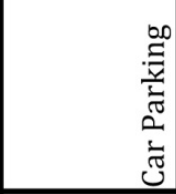 & 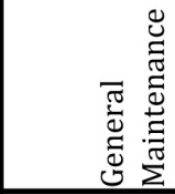 & $\begin{array}{l}\text { U. } \\
\text { : }\end{array}$ \\
\hline Whakapara Hall & $\begin{array}{l}\text { On side of what used to be the main } \\
\text { road north - now on corner site; rain } \\
\text { water collection; some graffiti and } \\
\text { rubbish around grounds; } \\
\text { amalgamation of different building } \\
\text { lines }\end{array}$ & $\begin{array}{l}\text { Metal truss roof ties; timber and } \\
\text { fibre cement bevel back weather } \\
\text { boards; long run colour steel } \\
\text { roofing; timber floors }\end{array}$ & - & None & \begin{tabular}{|l|} 
Sealed car \\
parking - \\
potholes \\
developing; \\
limited \\
visibility; \\
parking direct \\
access off road
\end{tabular} & $\begin{array}{l}\text { Lacks detailing } \\
\text { around } \\
\text { windows etc; } \\
\text { generally well } \\
\text { kept; }\end{array}$ & $\begin{array}{l}\text { Extension } \\
\text { requires re- } \\
\text { roofing - } \\
\text { rusted and } \\
\text { mouldy; hall } \\
\text { roof in good } \\
\text { condition }\end{array}$ \\
\hline Waiotira Hall & $\begin{array}{l}\text { Hall placed at rear of site with car } \\
\text { parking in front; simple form with of } \\
\text { gable ended hall with lean-to; one of } \\
\text { the newest halls sampled; profiled } \\
\text { iron hall with board and batten } \\
\text { kitchen and toilet extension to front; } \\
\text { covered main entrance and side } \\
\text { entrances }\end{array}$ & $\begin{array}{l}\text { Profiled iron main body of hall; } \\
\text { board and batten lean-to kitchen } \\
\text { and toilets; galvanised iron roofs; } \\
\text { internal walls of vanished timber }\end{array}$ & $\begin{array}{l}\text { Pony club } \\
\text { across road; } \\
\text { Golf club up } \\
\text { behind }\end{array}$ & $\begin{array}{l}\text { Concrete steps } \\
\text { out front } \\
\text { require } \\
\text { reworking }\end{array}$ & $\begin{array}{l}\text { Duel entrance } \\
\text { metal parking } \\
\text { area; grass } \\
\text { beginning to } \\
\text { take over }\end{array}$ & $\begin{array}{l}\text { Reasonably } \\
\text { modern } \\
\text { building } \\
\text { therefore } \\
\text { easier to take } \\
\text { care of }\end{array}$ & $\begin{array}{l}\text { Corrugated } \\
\text { long run iron; } \\
\text { low angle } \\
\text { pitch to roof; } \\
\text { some } \\
\text { flashings and } \\
\text { spouting } \\
\text { beginning to } \\
\text { turn }\end{array}$ \\
\hline Mata Hall & $\begin{array}{l}\text { Rain water collection; stage } \\
\text { removed - now patch on floor; new } \\
\text { concrete path, disabled access and } \\
\text { side entrance; no ceiling lining }\end{array}$ & $\begin{array}{l}150 \text { bevel back timber } \\
\text { weatherboards; corrugate iron } \\
\text { roof; wooden sash windows; } \\
\text { polished timber floor; }\end{array}$ & Tennis Courts & $\begin{array}{l}\text { Grassed area } \\
\text { overflowing on } \\
\text { metal; } \\
\text { concrete } \\
\text { paths; kikuyu } \\
\text { grass taking } \\
\text { over; no } \\
\text { defined edges }\end{array}$ & $\begin{array}{l}\text { Off road edge } \\
\text { on metal with } \\
\text { overflow on to } \\
\text { large grassed } \\
\text { area }\end{array}$ & $\begin{array}{l}\text { Some mould } \\
\text { seen but } \\
\text { generally tidy }\end{array}$ & $\begin{array}{l}\text { Galvanised } \\
\text { iron with no } \\
\text { paint - some } \\
\text { mould }\end{array}$ \\
\hline
\end{tabular}




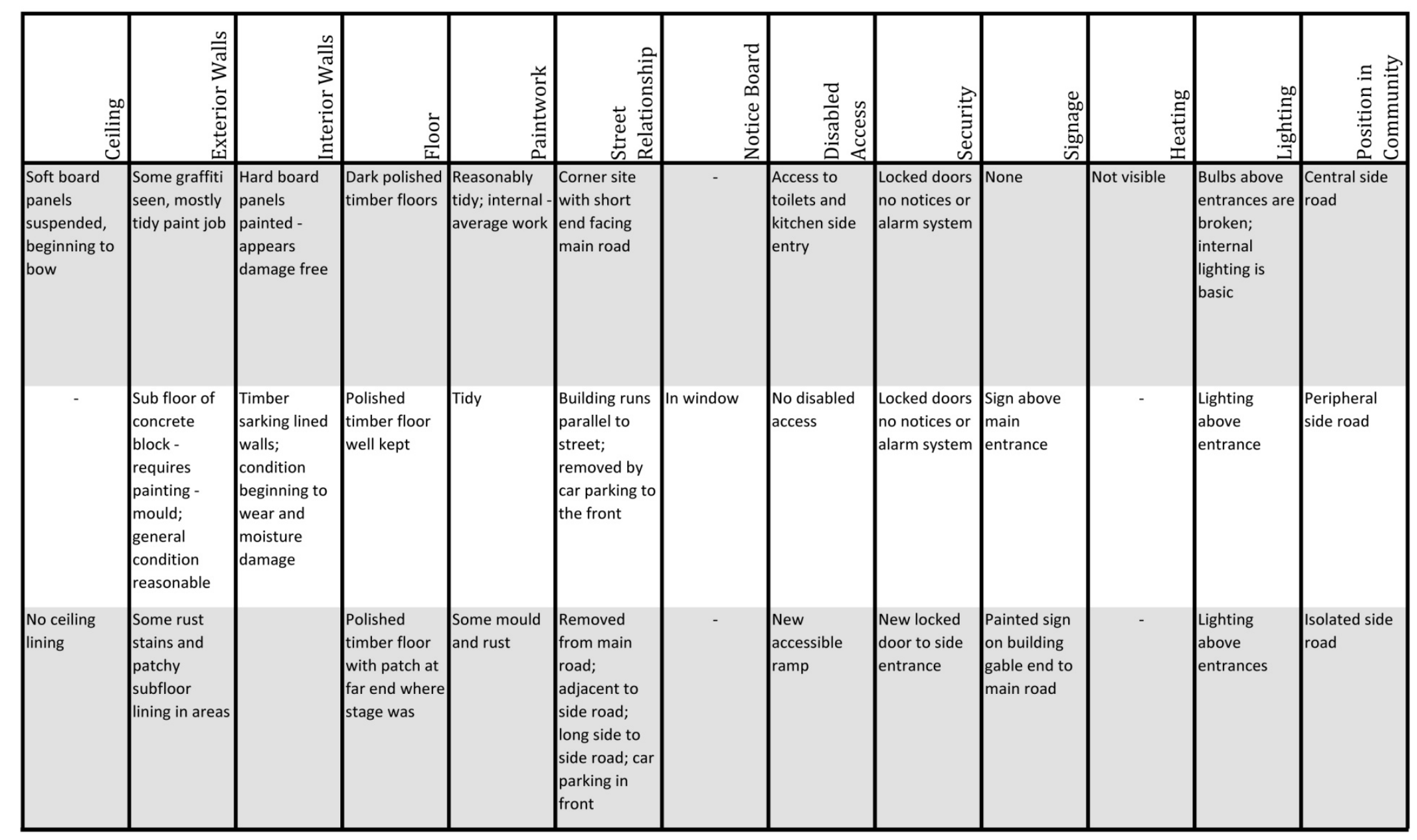




\begin{tabular}{|c|c|c|c|c|c|c|c|}
\hline Hall & 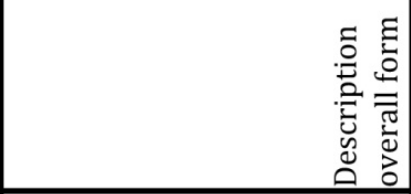 & 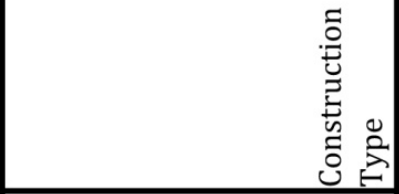 & 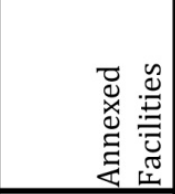 & 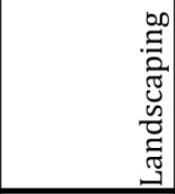 & 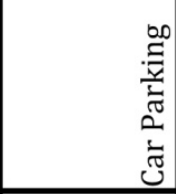 & 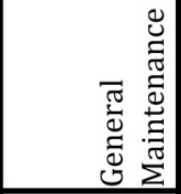 & $\begin{array}{l}\text { ü } \\
\text { : } \\
\end{array}$ \\
\hline Otaika Hall & $\begin{array}{l}\text { Town supply water; site shared with } \\
\text { harbour board; multiple roof lines, } \\
\text { building work does not flow, door } \\
\text { and window lines everywhere; } \\
\text { rough cuts to weather boards and } \\
\text { not matched to original; subfloor } \\
\text { lining roughly done; }\end{array}$ & $\begin{array}{l}\text { Bevel back timber weatherboards; } \\
\text { Corrugated iron roof; }\end{array}$ & $\begin{array}{l}\text { School across } \\
\text { the road; } \\
\text { popular local } \\
\text { swimming hole } \\
\text { behind hall; }\end{array}$ & $\begin{array}{l}\text { Some plantings } \\
\text { to rear by river }\end{array}$ & $\begin{array}{l}\text { Off road edge } \\
\text { parking; } \\
\text { limited }\end{array}$ & $\begin{array}{l}\text { Relatively poor } \\
\text { condition of } \\
\text { building; } \\
\text { requires } \\
\text { painting and } \\
\text { general } \\
\text { maintenance }\end{array}$ & $\begin{array}{l}\text { Mouldy, rusty } \\
\text { state of iron }\end{array}$ \\
\hline Parakao Hall & $\begin{array}{l}\text { Hall situated on outside of corner, } \\
\text { open front to car parking; hard to } \\
\text { access sides of halls, almost hidden } \\
\text { in paddock and mature trees; } \\
\text { Mobile Library Bus Stop; rubbish in } \\
\text { car park; site appears cold and damp }\end{array}$ & $\begin{array}{l}\text { Timber rusticated weatherboards } \\
\text { to original hall; bevel back to } \\
\text { meeting room off side; corrugated } \\
\text { iron roof }\end{array}$ & $\begin{array}{l}\text { Play centre; } \\
\text { public toilets }\end{array}$ & $\begin{array}{l}\text { Picnic table out } \\
\text { front of hall; } \\
\text { limited } \\
\text { plantings - } \\
\text { overgrown - to } \\
\text { entrance; }\end{array}$ & $\begin{array}{l}\text { Metal area on } \\
\text { outside of } \\
\text { corner; } \\
\text { marginal } \\
\text { potholes }\end{array}$ & $\begin{array}{l}\text { Graffiti painted } \\
\text { out with thin } \\
\text { layer of paint; } \\
\text { mouldy }\end{array}$ & $\begin{array}{l}\text { Galvanised } \\
\text { long run iron; } \\
\text { some rust; } \\
\text { spouting } \\
\text { growing } \\
\text { mould and } \\
\text { filled with } \\
\text { grass }\end{array}$ \\
\hline Marua Hall & $\begin{array}{l}\text { On a recreation reserve - not } \\
\text { apparent on site - appears as farm } \\
\text { land; rain water collection; back not } \\
\text { looked after; tidy kitchen; appears } \\
\text { tired }\end{array}$ & $\begin{array}{l}\text { Bevel back timber weatherboards; } \\
\text { Corrugated iron roof; Polished } \\
\text { Timber floors; Interior painted } \\
\text { hard board linings walls and ceiling }\end{array}$ & - & $\begin{array}{l}\text { Surrounded by } \\
\text { post and wire } \\
\text { fencing; brown } \\
\text { rock metalling } \\
\text { everywhere }\end{array}$ & $\begin{array}{l}\text { All around } \\
\text { building }\end{array}$ & $\begin{array}{l}\text { Poor condition } \\
\text { of building; } \\
\text { mould, rust } \\
\text { and rot evident }\end{array}$ & $\begin{array}{l}\text { Mouldy, } \\
\text { rusting - short } \\
\text { run corrugate }\end{array}$ \\
\hline
\end{tabular}




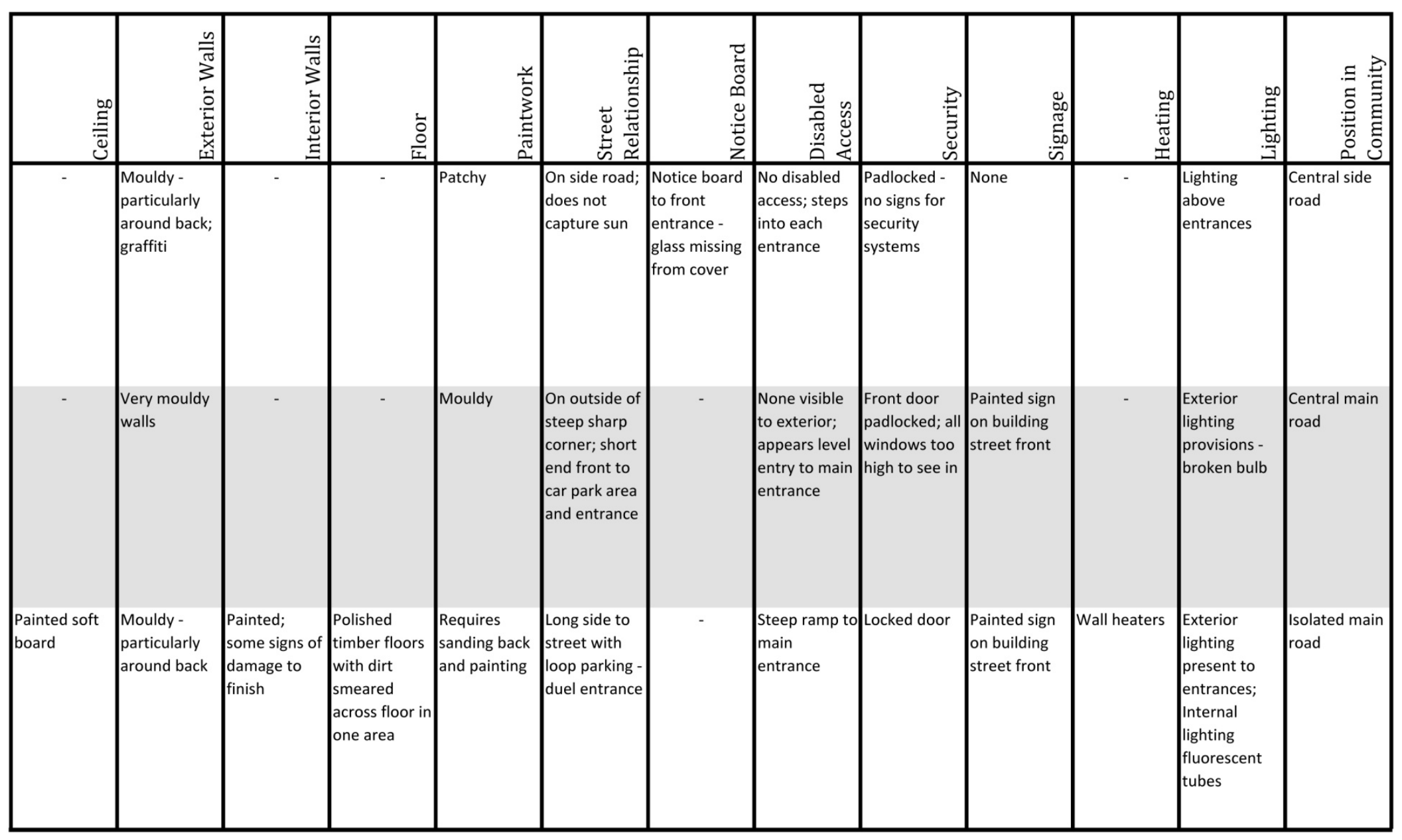




\begin{tabular}{|c|c|c|c|c|c|c|c|}
\hline Hall & 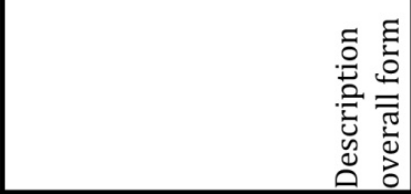 & 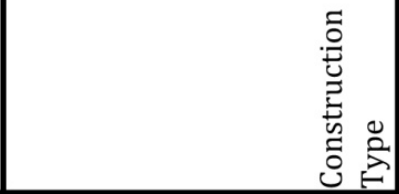 & 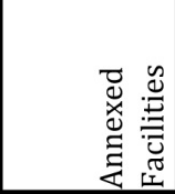 & 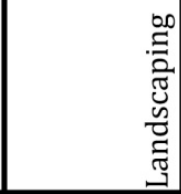 & 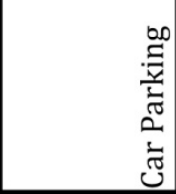 & 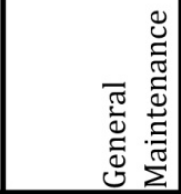 & 岁 \\
\hline Purua Hall & $\begin{array}{l}\text { Generally run down building; set } \\
\text { back in paddock above road; rain } \\
\text { water collection; original main hall in } \\
\text { reasonable condition - no rot; } \\
\text { extension not matching }\end{array}$ & $\begin{array}{l}\text { Original hall in board and batten, } \\
\text { kitchen extension in fibre cement } \\
\text { weatherboards; corrugated short } \\
\text { run iron; polished timber floors; } \\
\text { unlined ceiling and walls above } 3 \mathrm{~m}\end{array}$ & - & $\begin{array}{l}\text { Sited in middle } \\
\text { of paddock; } \\
\text { some plantings } \\
\text { as memorial to } \\
\text { the settlers in } \\
\text { the area; } \\
\text { mouldy paths; }\end{array}$ & $\begin{array}{l}\text { Roundabout } \\
\text { set up of } \\
\text { driveway; sign } \\
\text { to tell which } \\
\text { way to go; no } \\
\text { car parking as } \\
\text { such }\end{array}$ & $\begin{array}{l}\text { Tired building; } \\
\text { some exterior } \\
\text { materials } \\
\text { breaking; } \\
\text { general } \\
\text { conditions } \\
\text { good } \\
\text { underneath } \\
\text { the mould }\end{array}$ & $\begin{array}{l}\text { Corrugated } \\
\text { iron } \\
\text { unpainted; } \\
\text { multiple roof } \\
\text { lines; side } \\
\text { entrance } \\
\text { cover } \\
\text { intersects } \\
\text { with window }\end{array}$ \\
\hline Portland Hall & $\begin{array}{l}\text { Hall hidden from main streets and } \\
\text { passersby up a side road; Built 1921; } \\
\text { appears to have been purpose built } \\
\text { with projector room to one end; } \\
\text { appears to have been let go; } \\
\text { building was open and gym gear left } \\
\text { out; plastered buttresses along } \\
\text { exterior; dank and smelly interior }\end{array}$ & $\begin{array}{l}\text { Rough cast plaster walls; hip and } \\
\text { gable roof lines, galvanised long } \\
\text { run iron; polished timber floors; } \\
\text { hard board upper walls with solid } \\
\text { plaster below; panelled ceiling with } \\
\text { exposed timber beams }\end{array}$ & $\begin{array}{l}\text { Church; tennis } \\
\text { courts }\end{array}$ & $\begin{array}{l}\text { Tree lined } \\
\text { entrance along } \\
\text { side road, } \\
\text { some planting - } \\
\text { overgrown; } \\
\text { concrete paths } \\
\text { mouldy and } \\
\text { slippery }\end{array}$ & $\begin{array}{l}\text { Limited } \\
\text { parking; } \\
\text { singular lane } \\
\text { around hall } \\
\text { with duel } \\
\text { entrance; } \\
\text { parking area } \\
\text { overgrown } \\
\text { with kikuyu }\end{array}$ & $\begin{array}{l}\text { Very poor } \\
\text { condition of } \\
\text { building; } \\
\text { exterior } \\
\text { mouldy, } \\
\text { interior } \\
\text { moisture } \\
\text { damaged }\end{array}$ & $\begin{array}{l}\text { Galvanised } \\
\text { long run iron; } \\
\text { some rust; } \\
\text { spouting } \\
\text { growing } \\
\text { mould; down } \\
\text { pipes rusting }\end{array}$ \\
\hline $\begin{array}{l}\text { Maungatapere } \\
\text { Community Hall }\end{array}$ & $\begin{array}{l}\text { Form appears simple from road; } \\
\text { gable end of hall facing the road; } \\
\text { currently under renovations to roof - } \\
\text { will require a lot of money to get } \\
\text { back to a reasonable state; building } \\
\text { is rotting, mouldy and falling apart; } \\
\text { town supply water; lots of street } \\
\text { noise }\end{array}$ & $\begin{array}{l}\text { Concrete block entrance extension; } \\
\text { main hall of bevel back timber } \\
\text { weatherboards; side extension of } \\
\text { concrete block; back extension of } \\
\text { bevel back timber; roof to be long } \\
\text { run corrugated iron; subfloor lining } \\
\text { of volcanic rocks }\end{array}$ & Bowling club & $\begin{array}{l}\text { Landscaping to } \\
\text { memorial; } \\
\text { established } \\
\text { trees; raised } \\
\text { rock beds; } \\
\text { plantings to } \\
\text { adjacent } \\
\text { bowling greens }\end{array}$ & $\begin{array}{l}\text { Sealed car } \\
\text { parking with } \\
\text { pot holes } \\
\text { beginning to } \\
\text { develop; } \\
\text { starting to } \\
\text { develop } \\
\text { growth on } \\
\text { surface }\end{array}$ & $\begin{array}{l}\text { Building is in } \\
\text { very poor } \\
\text { condition; } \\
\text { broken, rotting } \\
\text { windows; } \\
\text { mould; rusted } \\
\text { spouting }\end{array}$ & $\begin{array}{l}\text { Currently } \\
\text { under } \\
\text { renovation }\end{array}$ \\
\hline
\end{tabular}




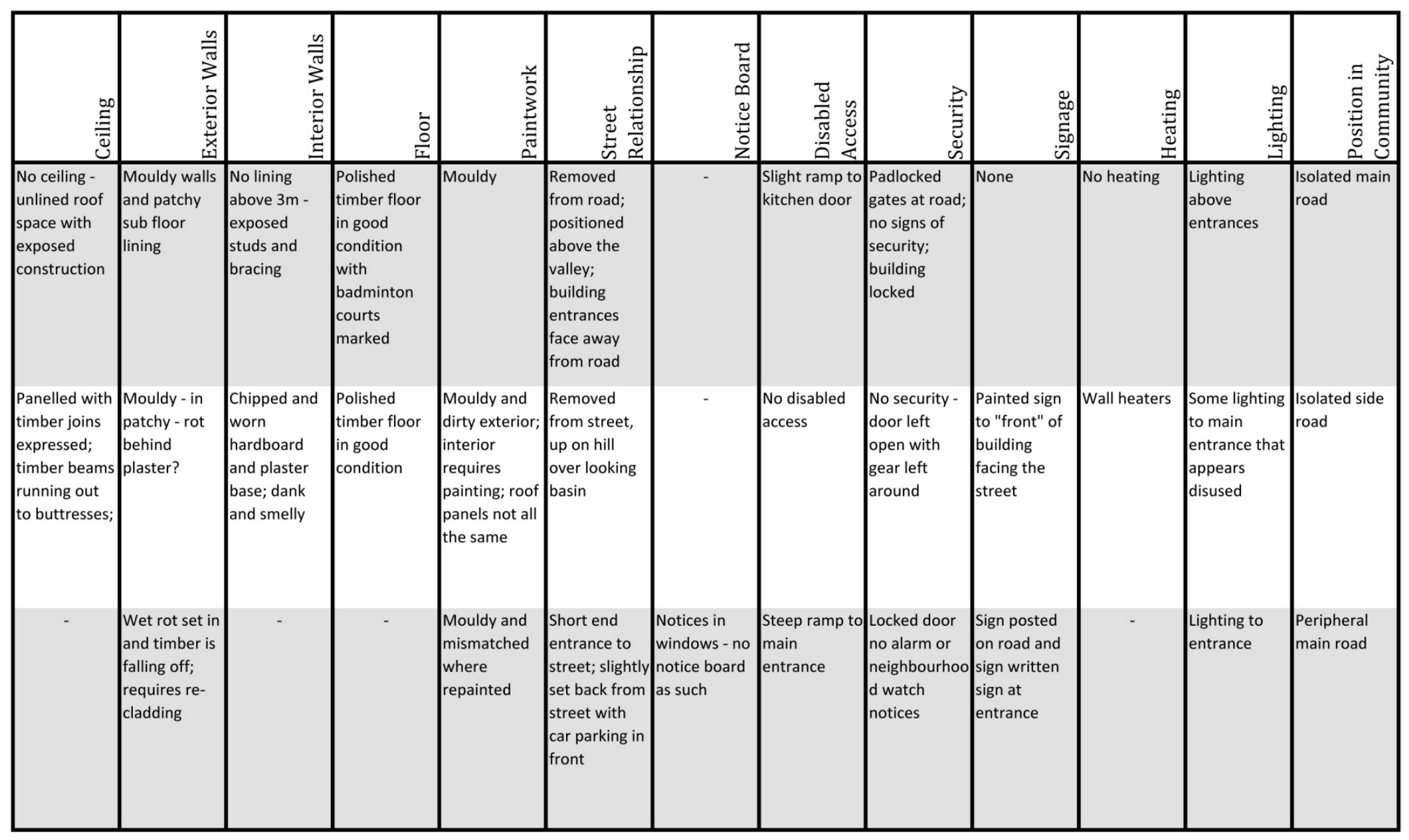




\subsection{Community Hall Analysis: Case Study Halls}
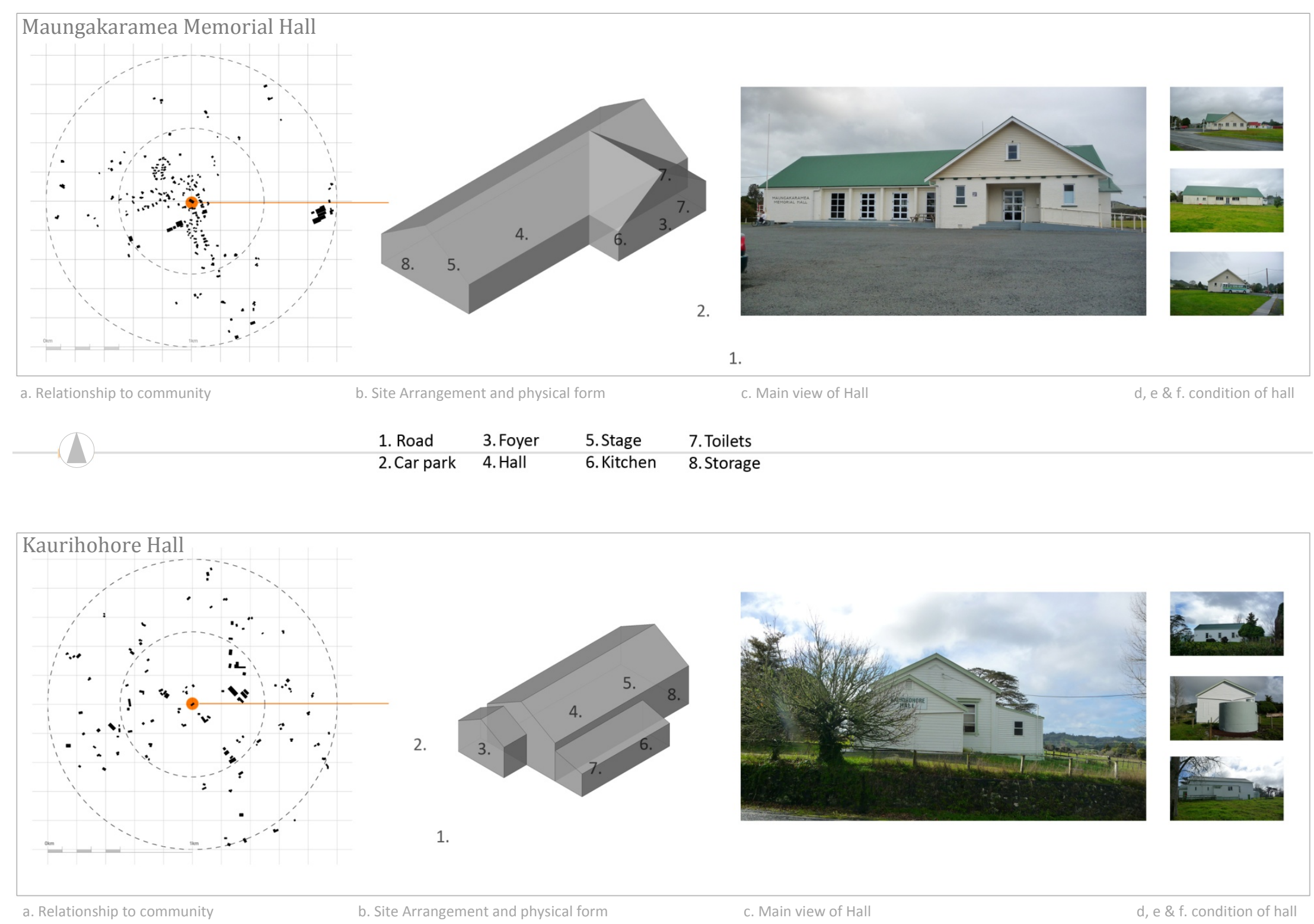

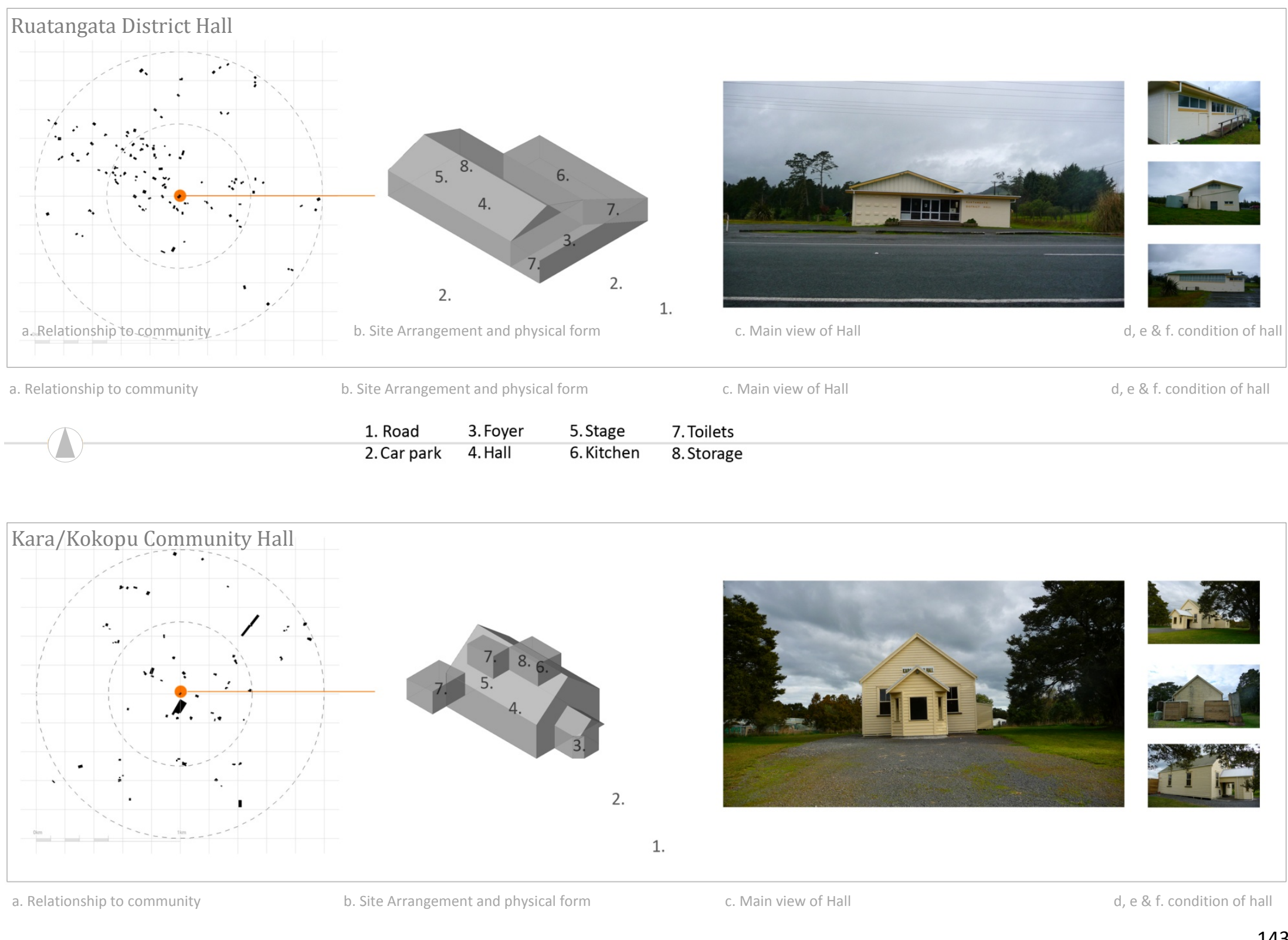

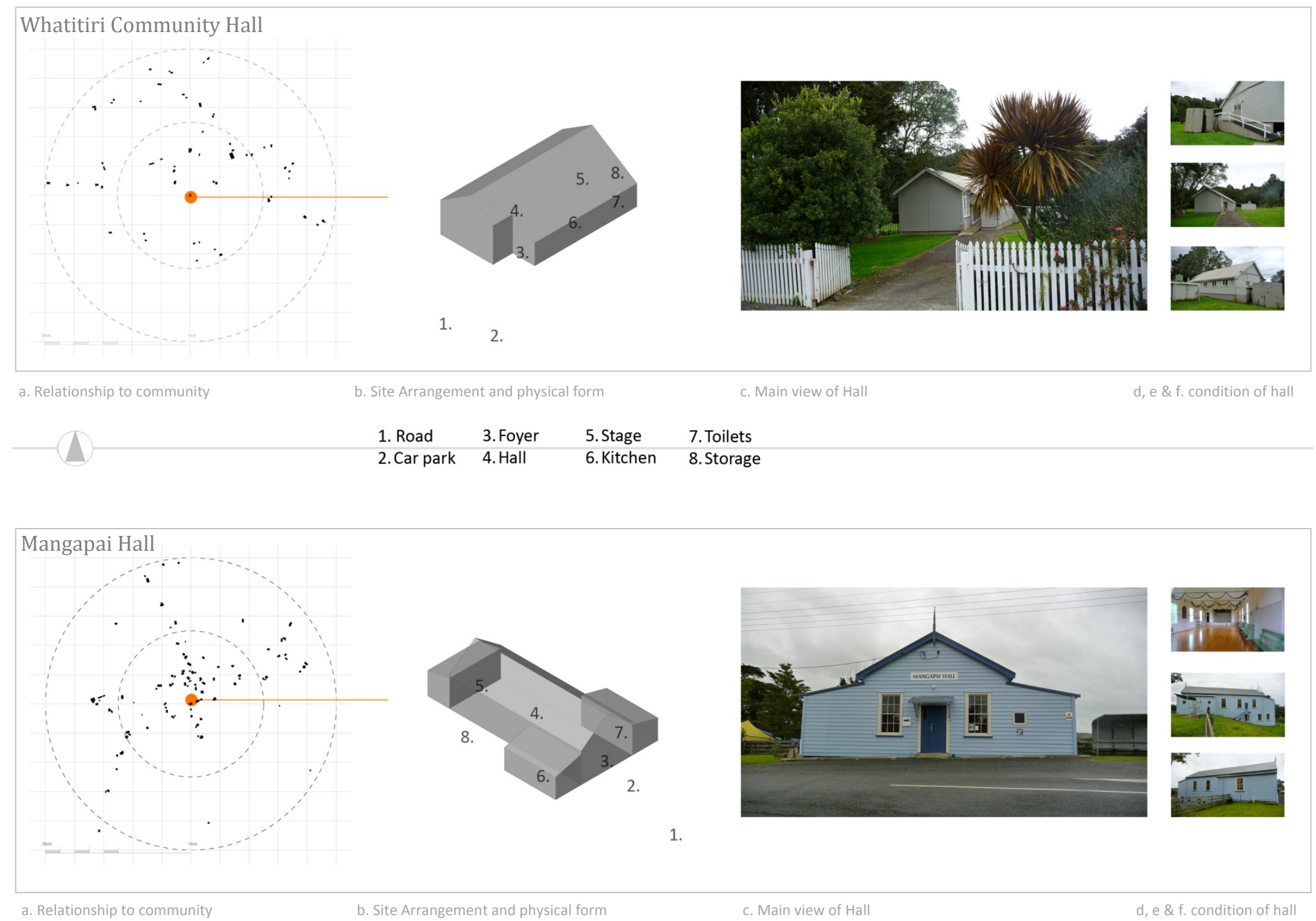

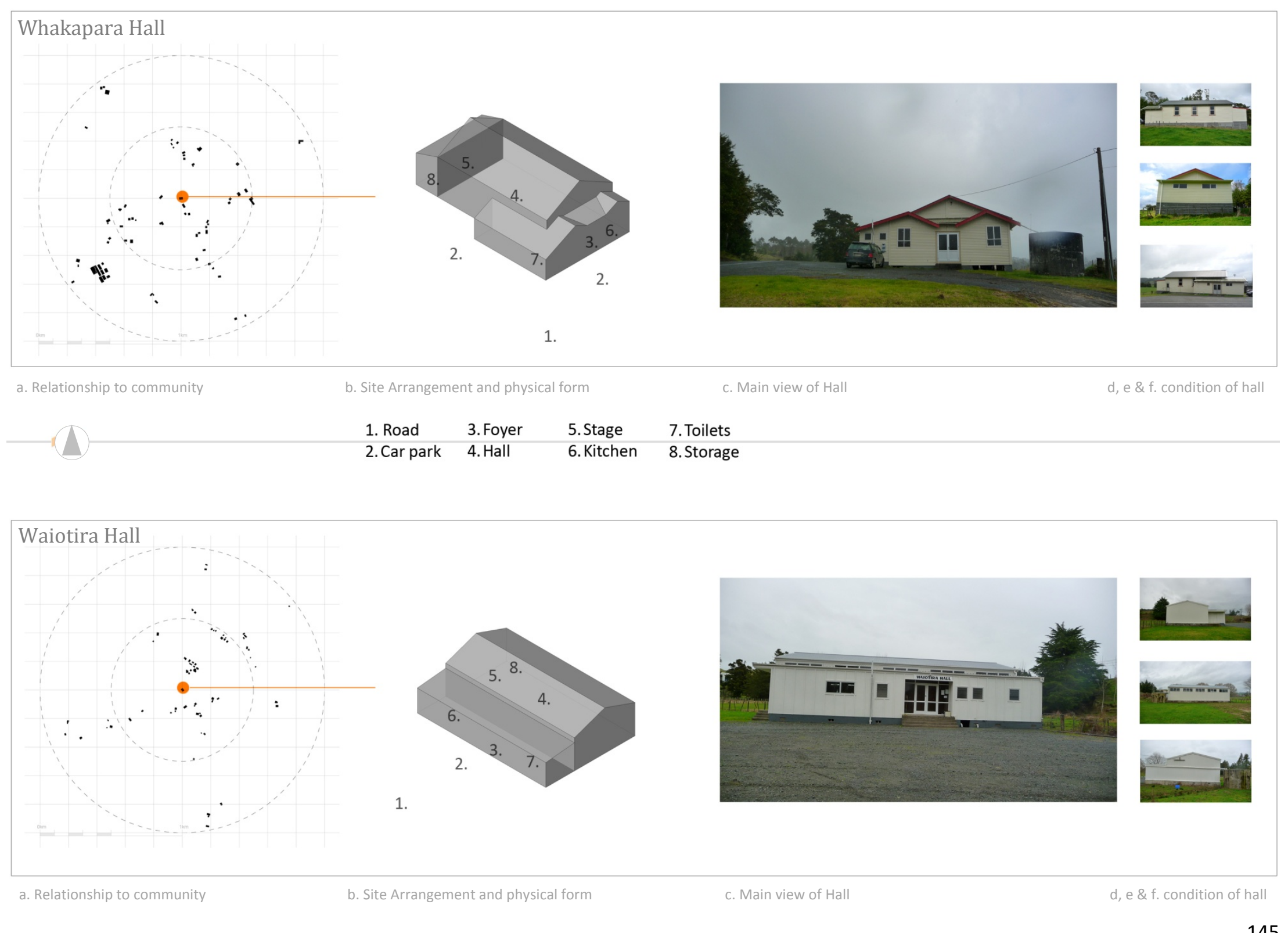

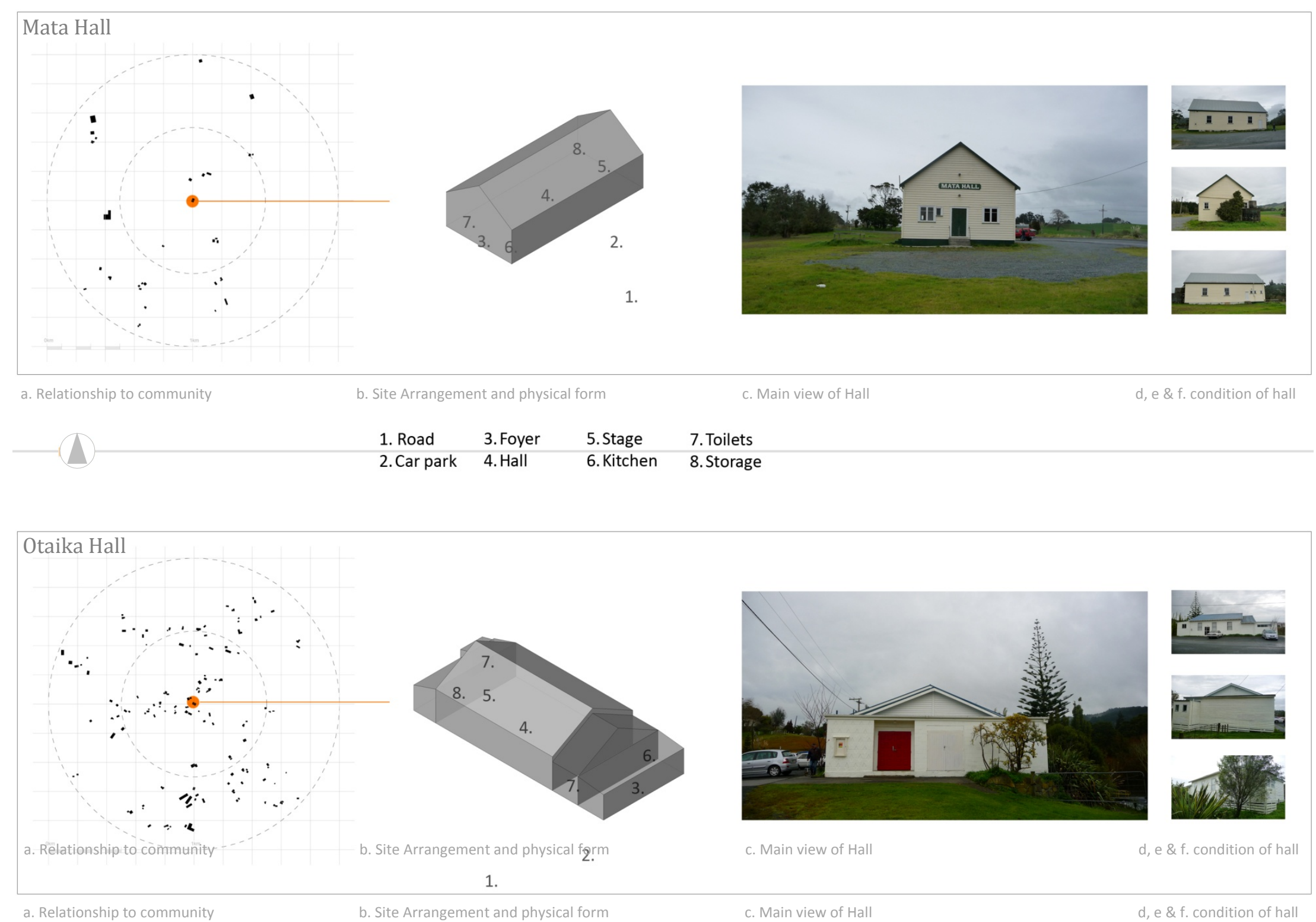

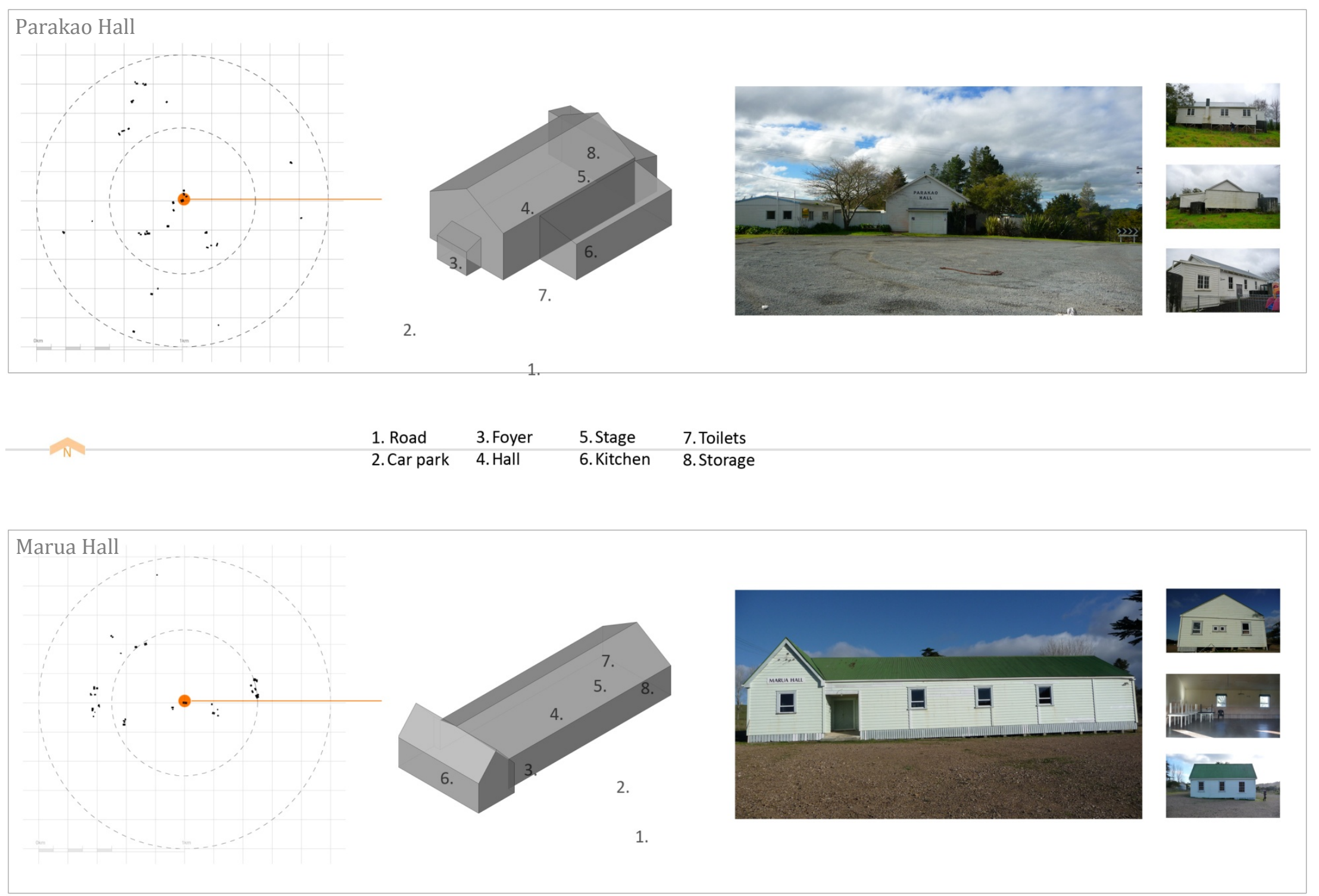

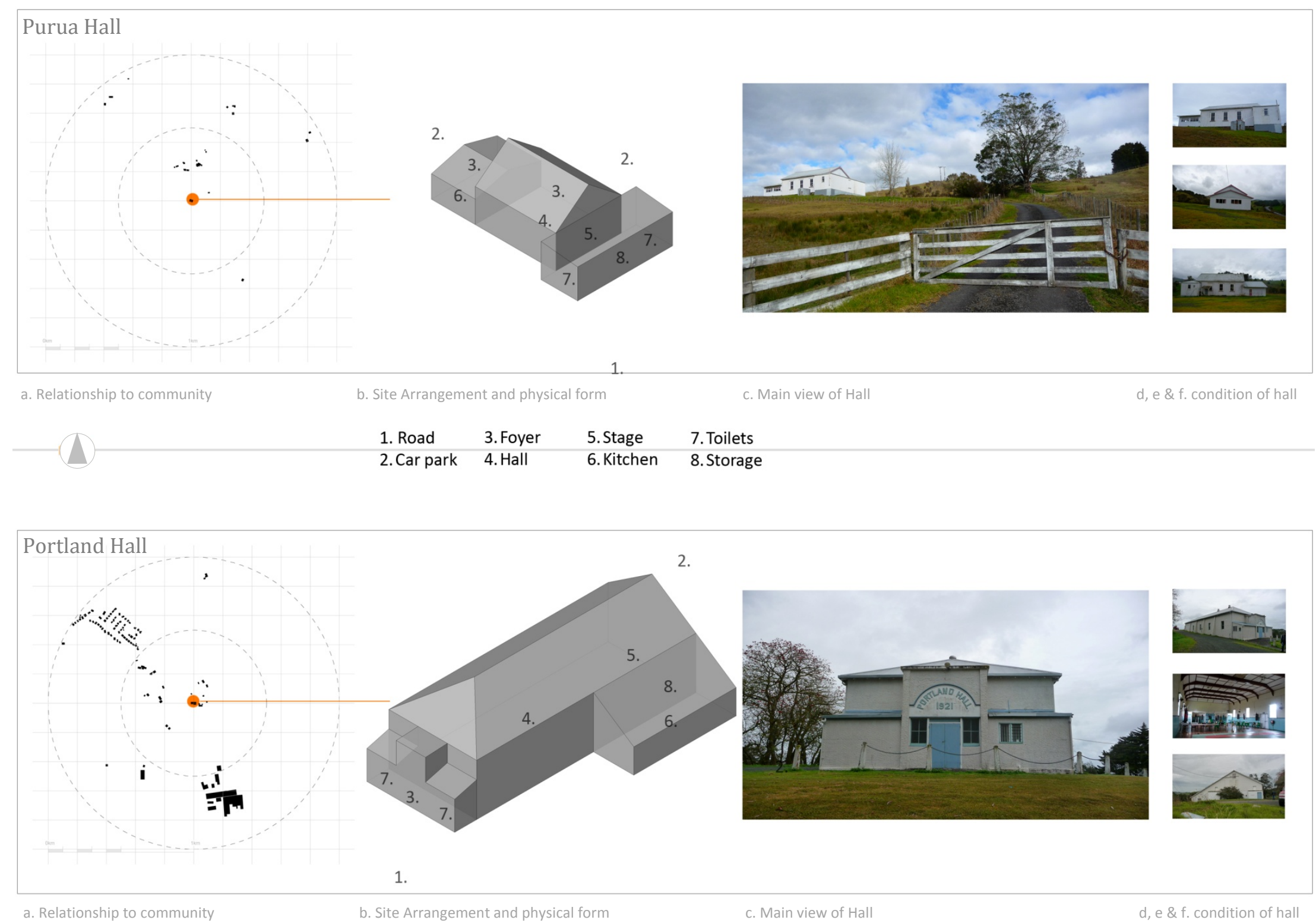


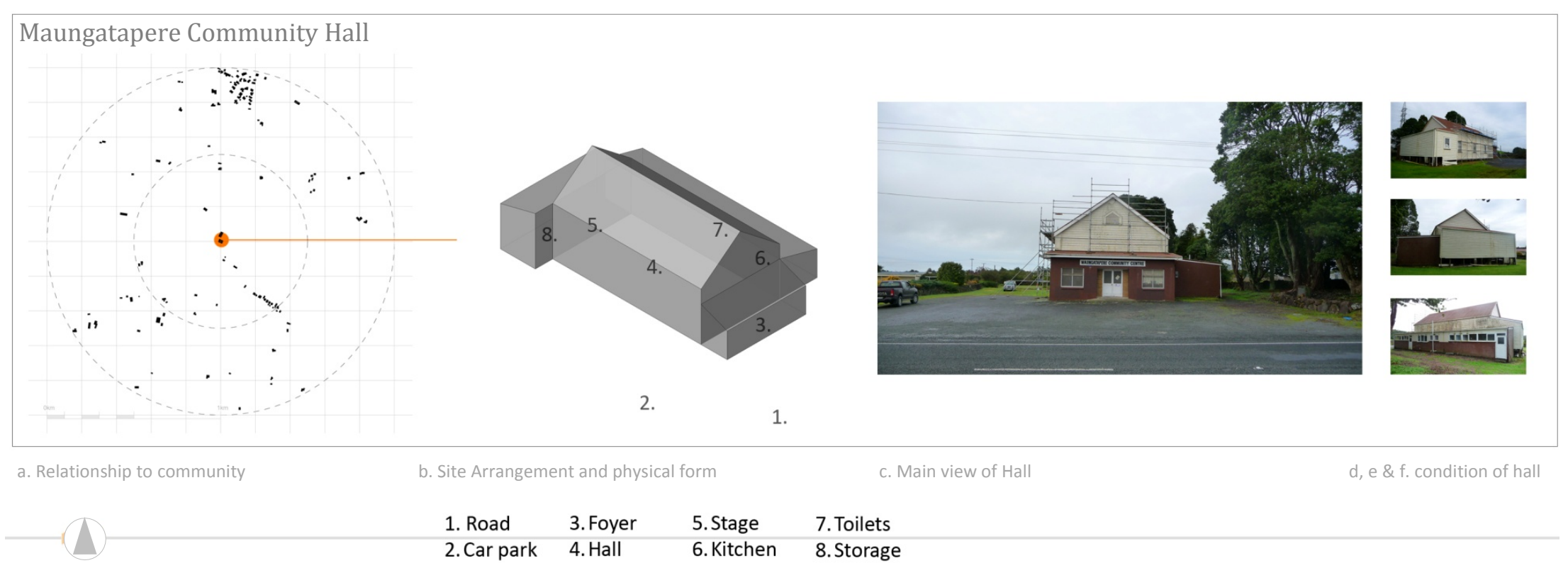


Appendix VI: Design Process 


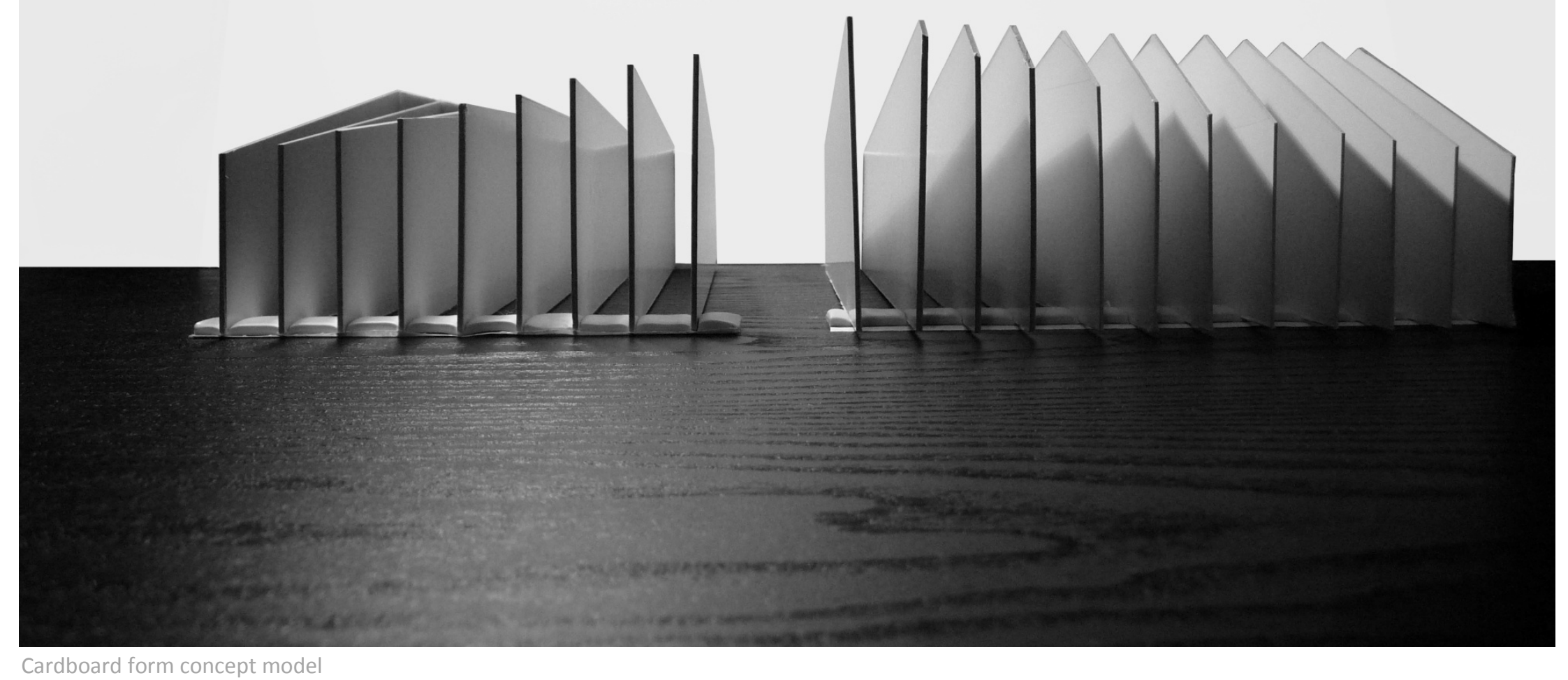




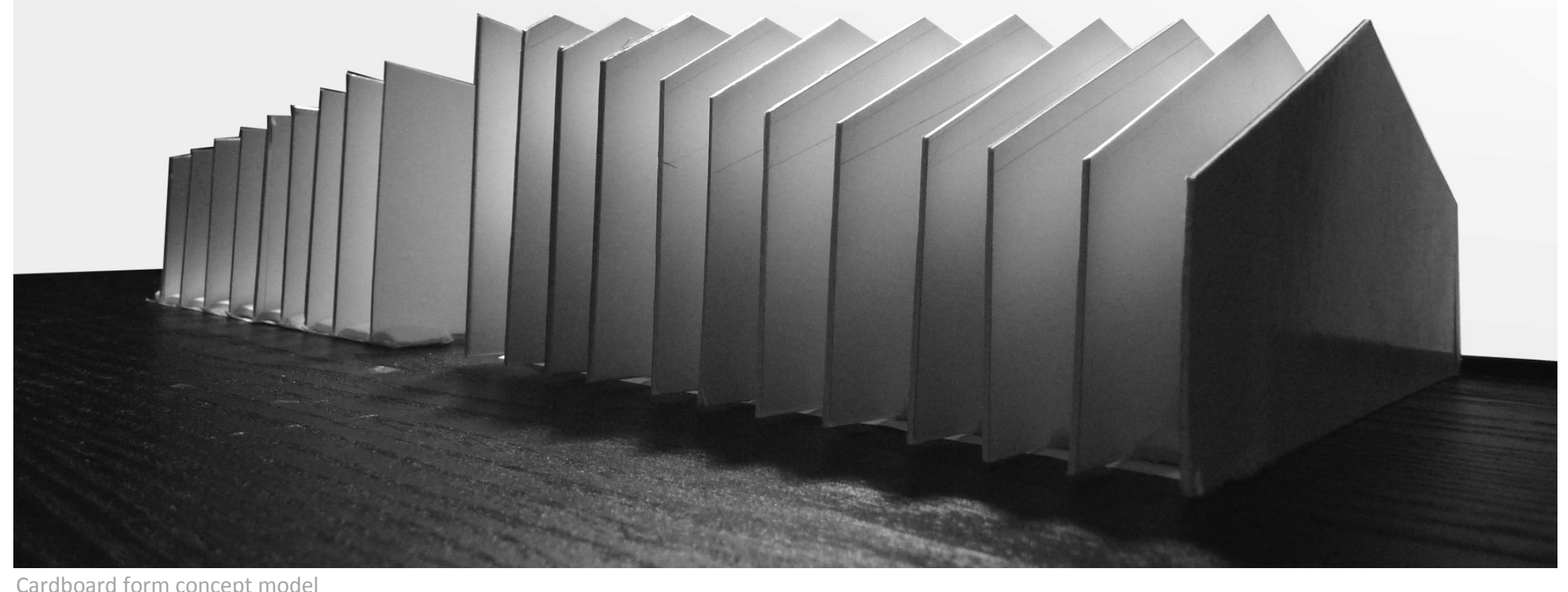




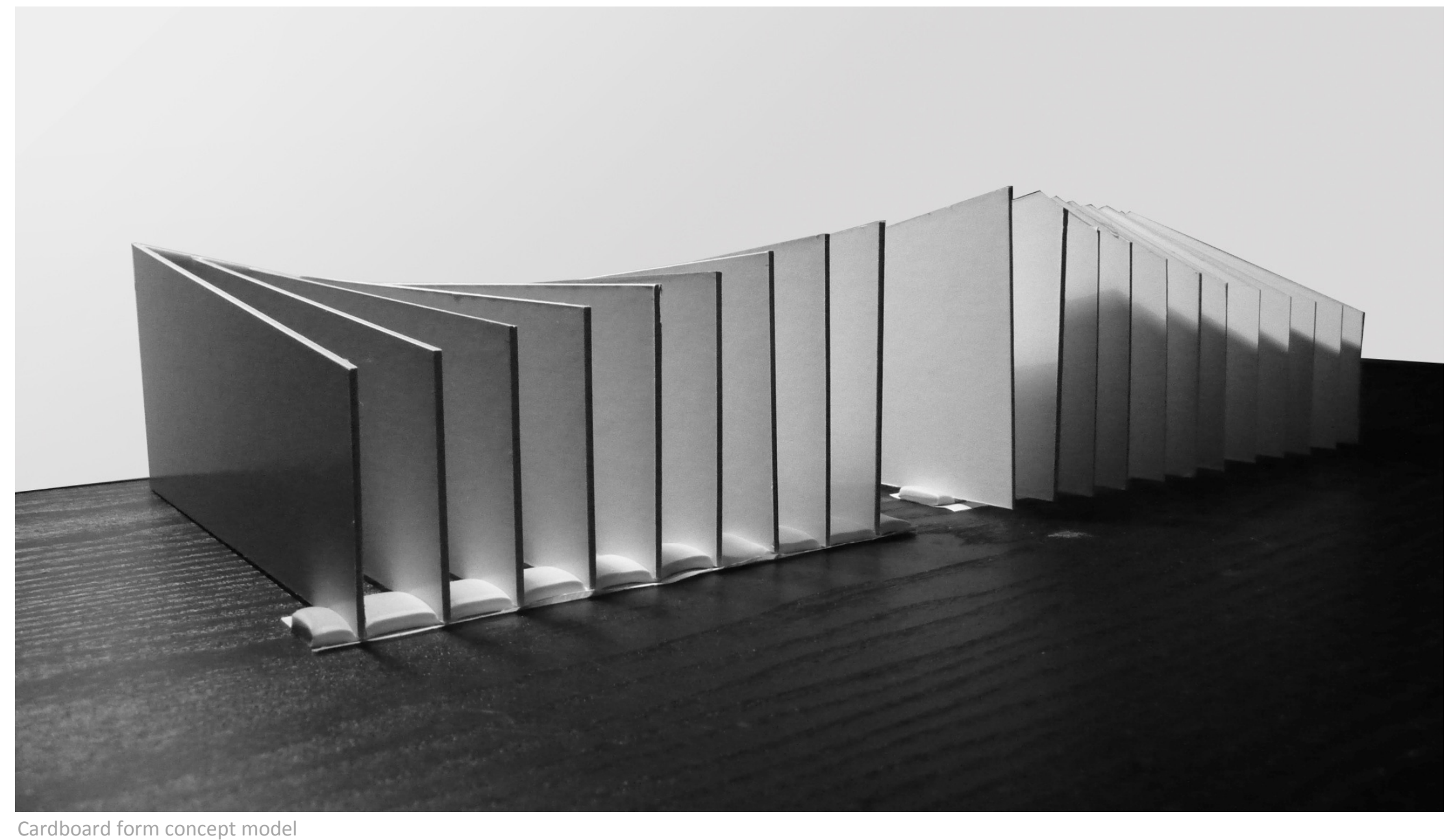




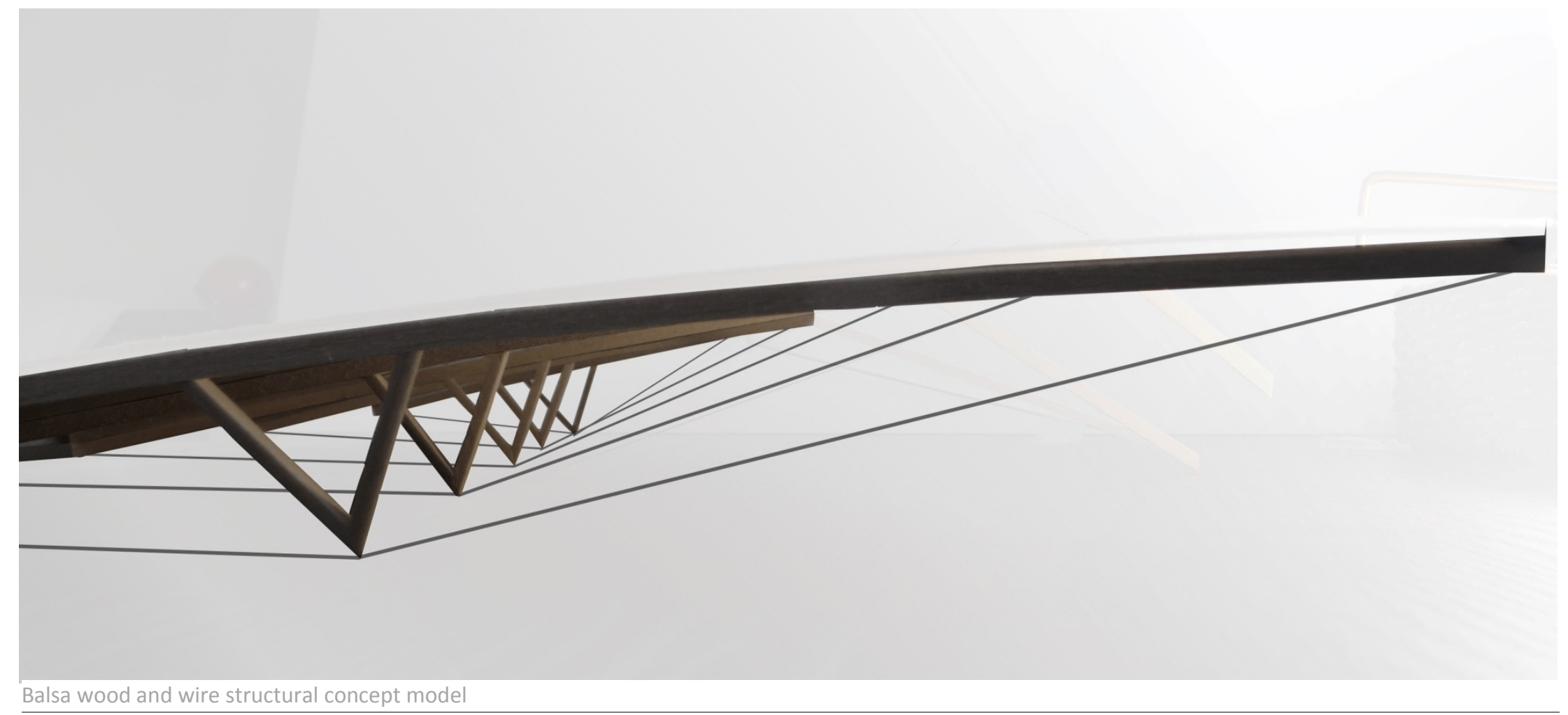




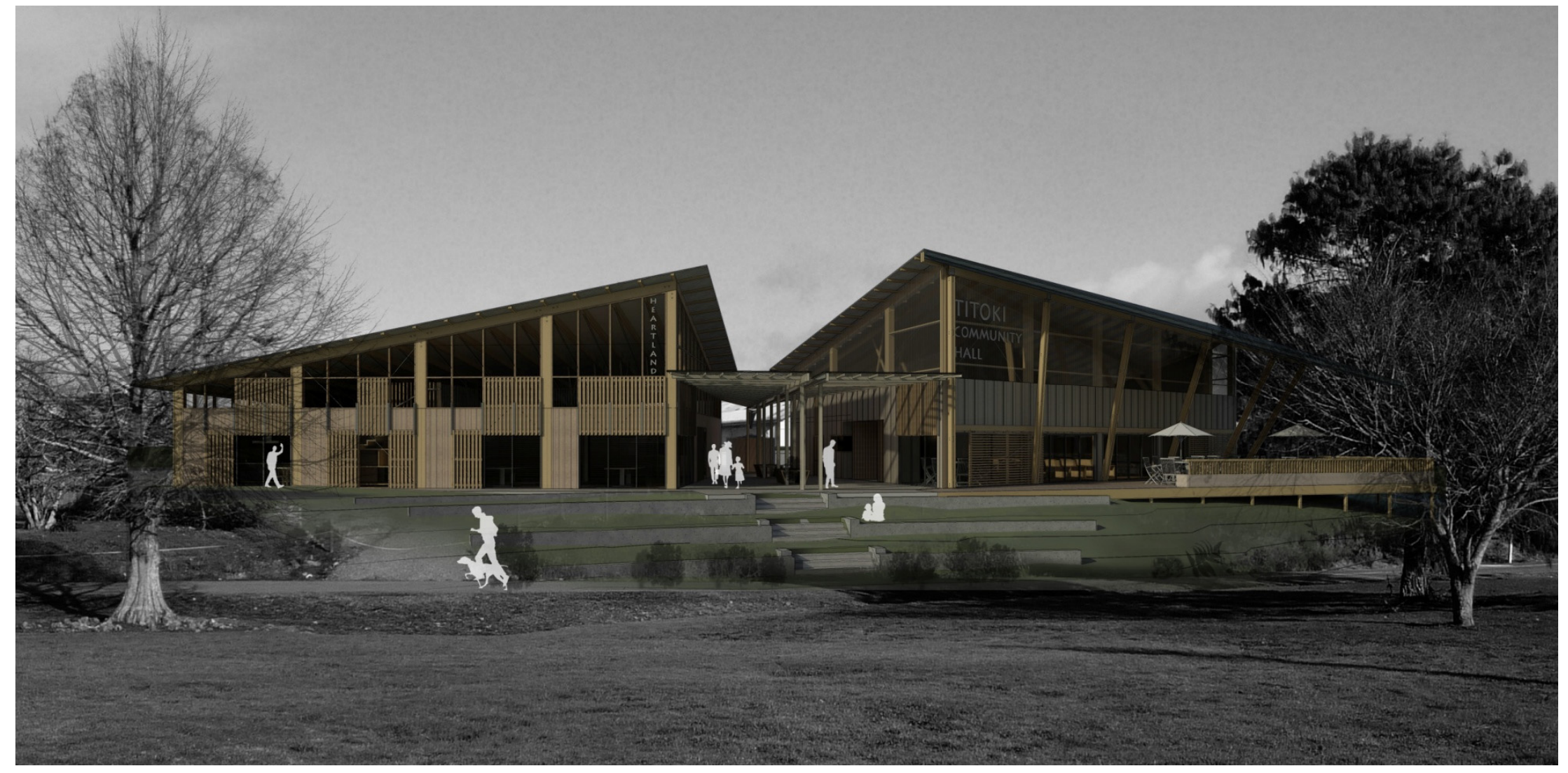

View from park up to Heartland Centre and Titoki Community Hall 


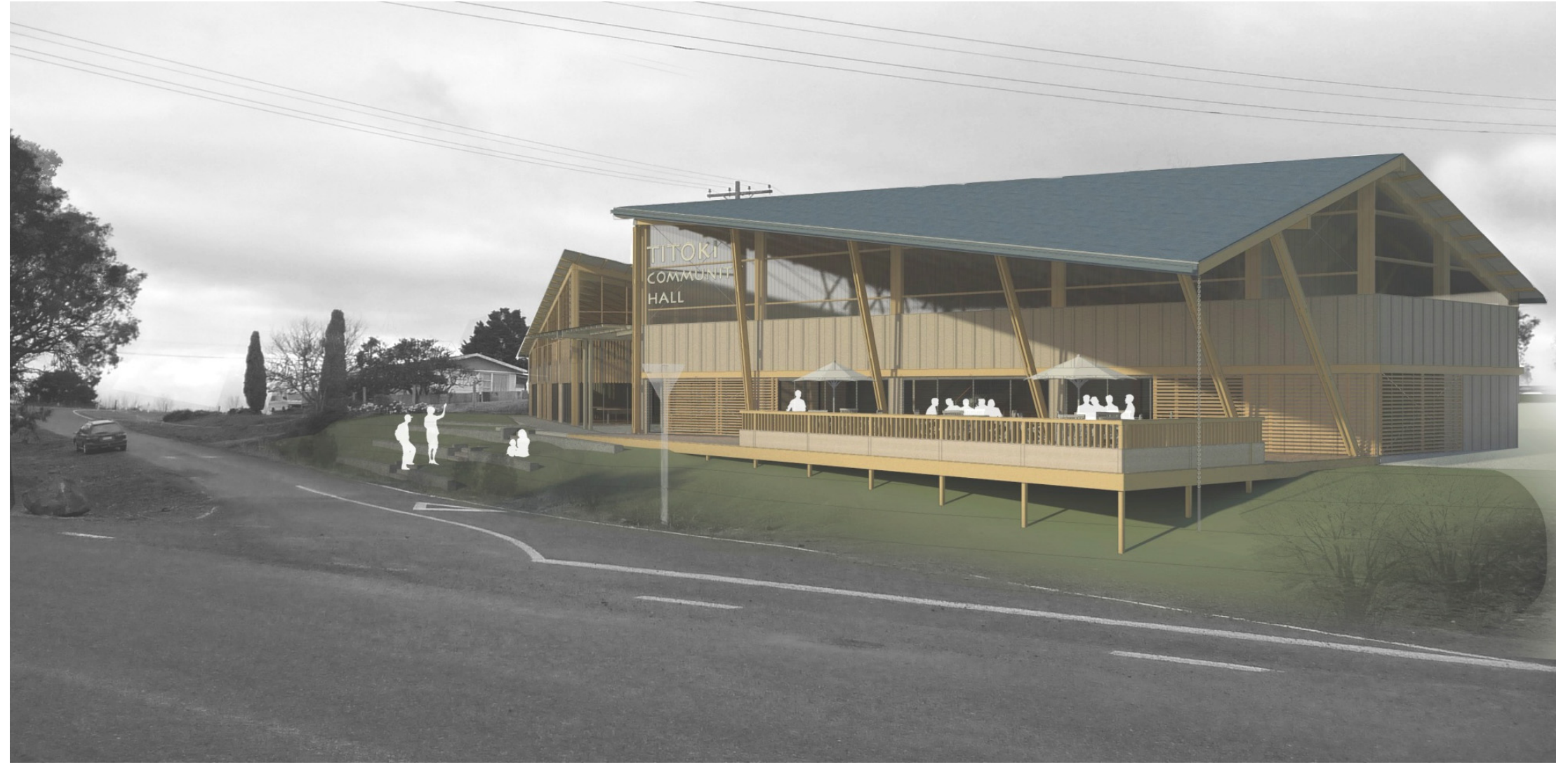

View from the North 

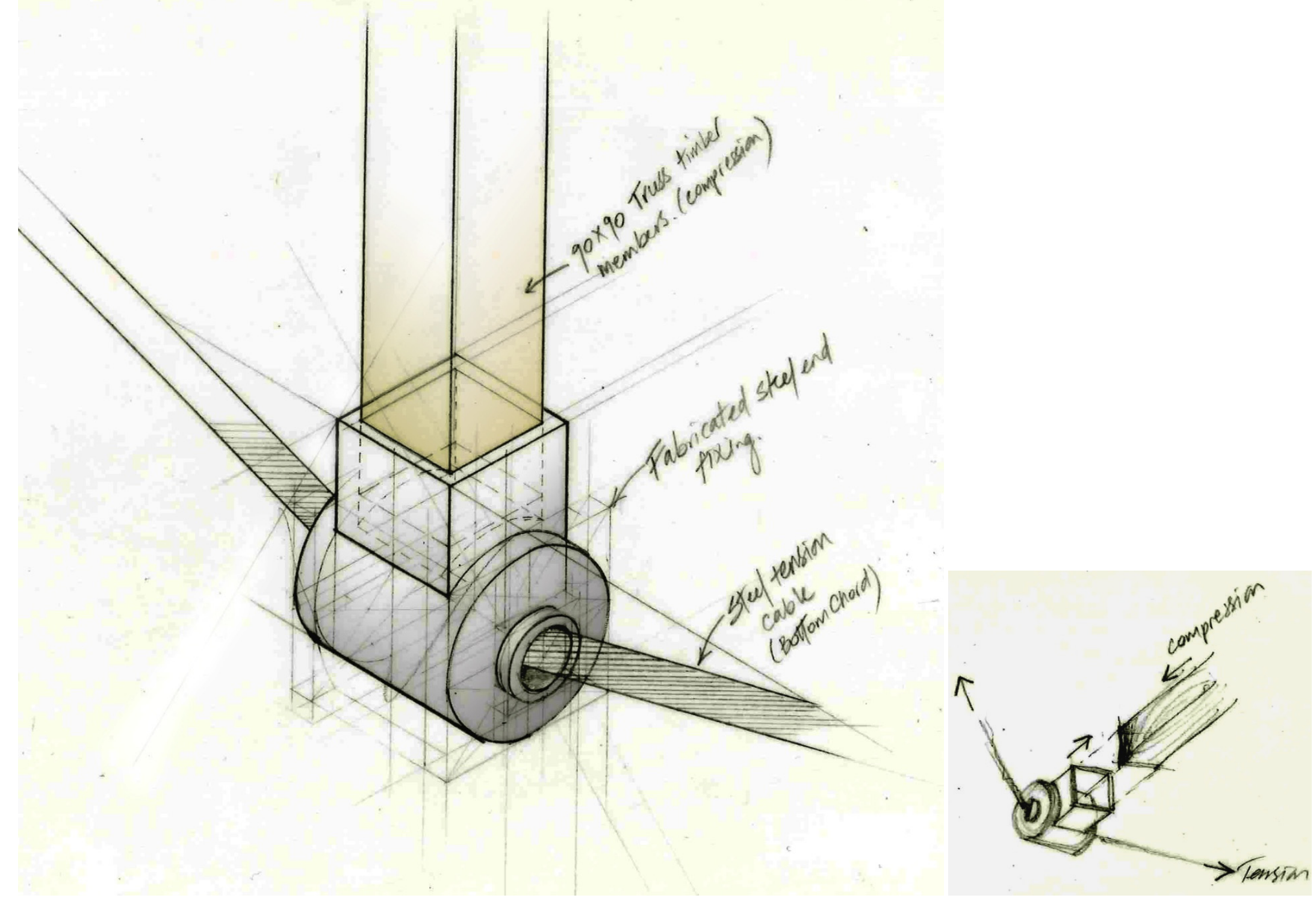


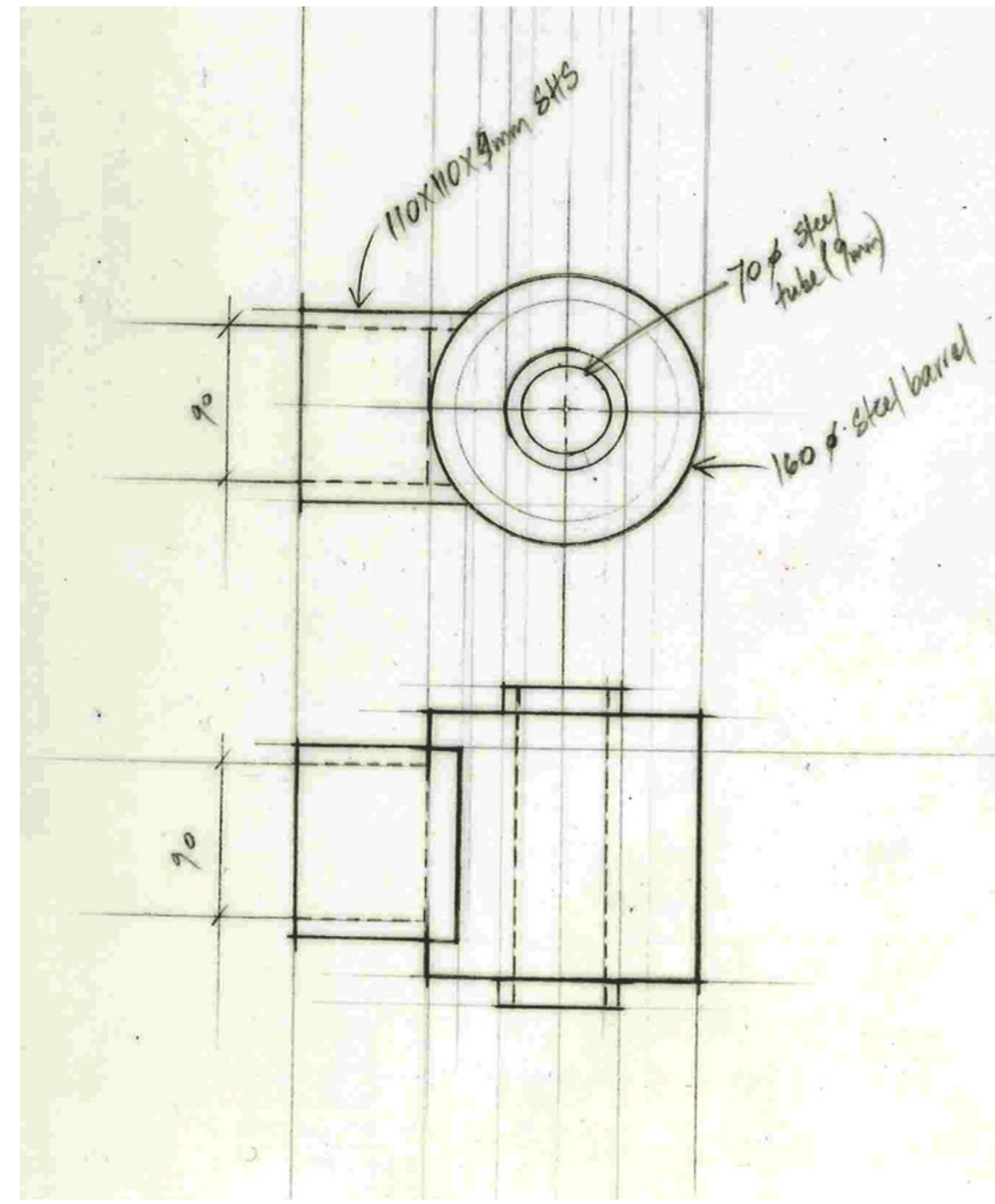

Sketch detail - end capping

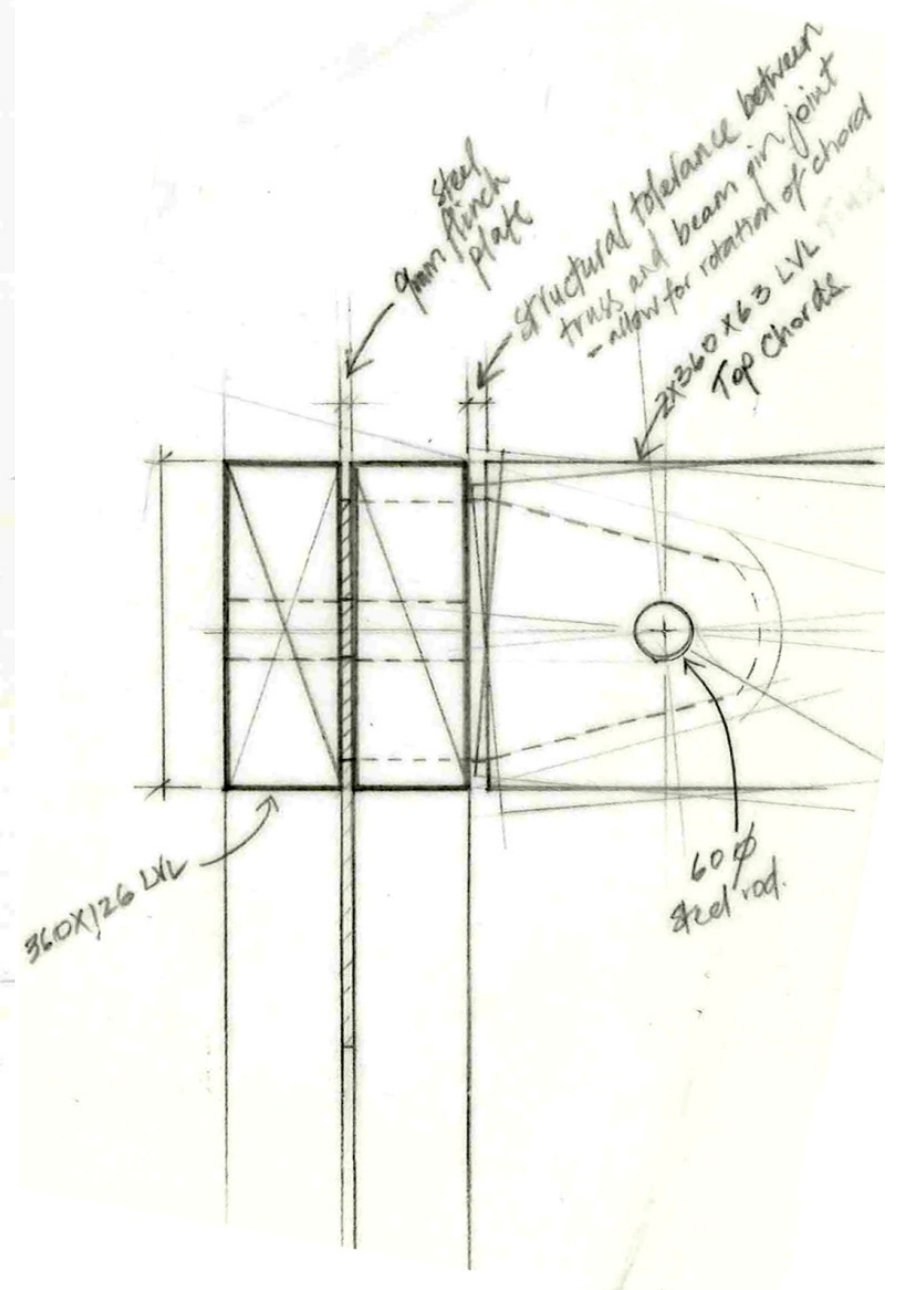

Sketch detail - truss end pin-joint 


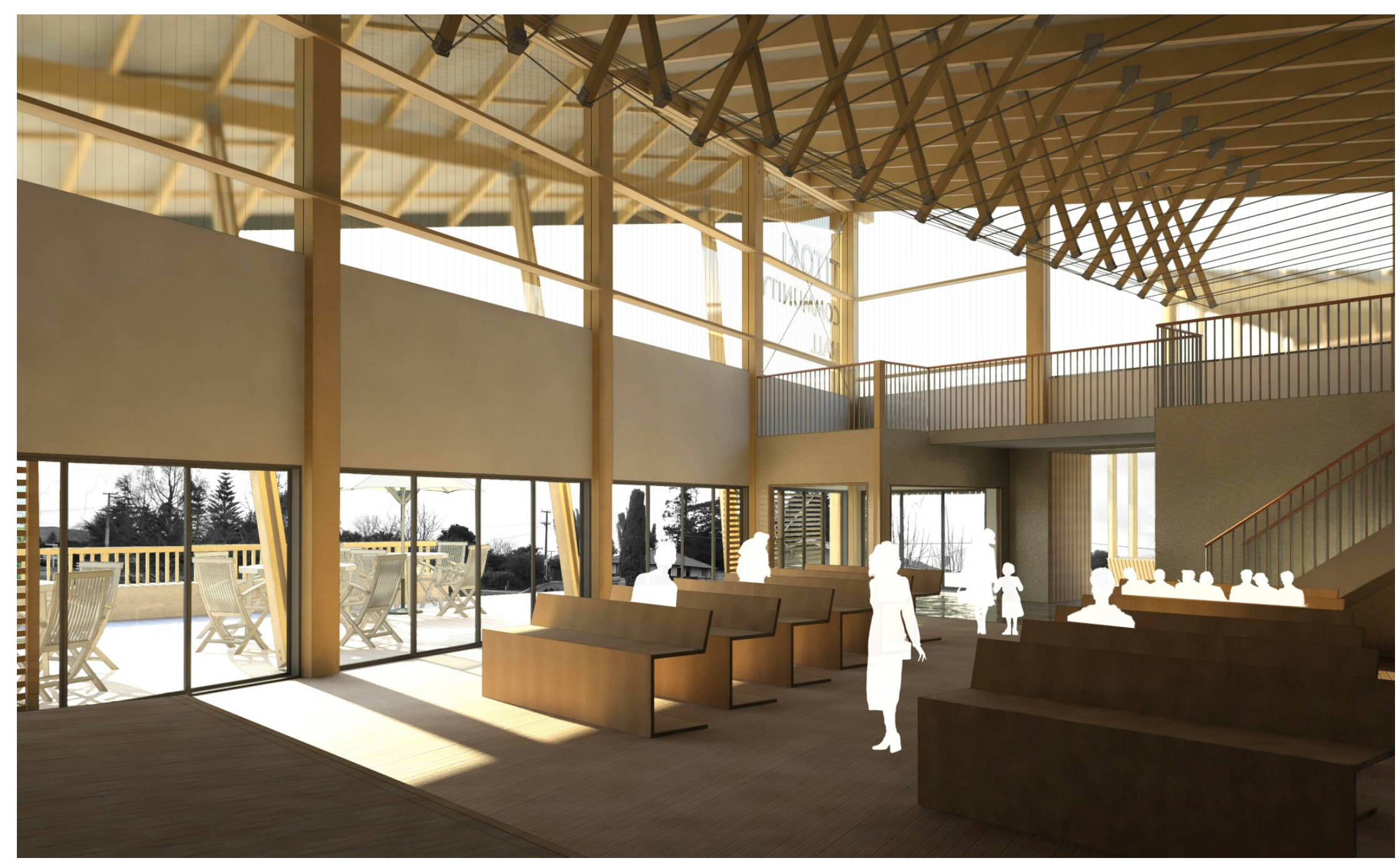

Structural expression - interior Titoki Community Hall 




Structural expression of propping the augmented veranda 


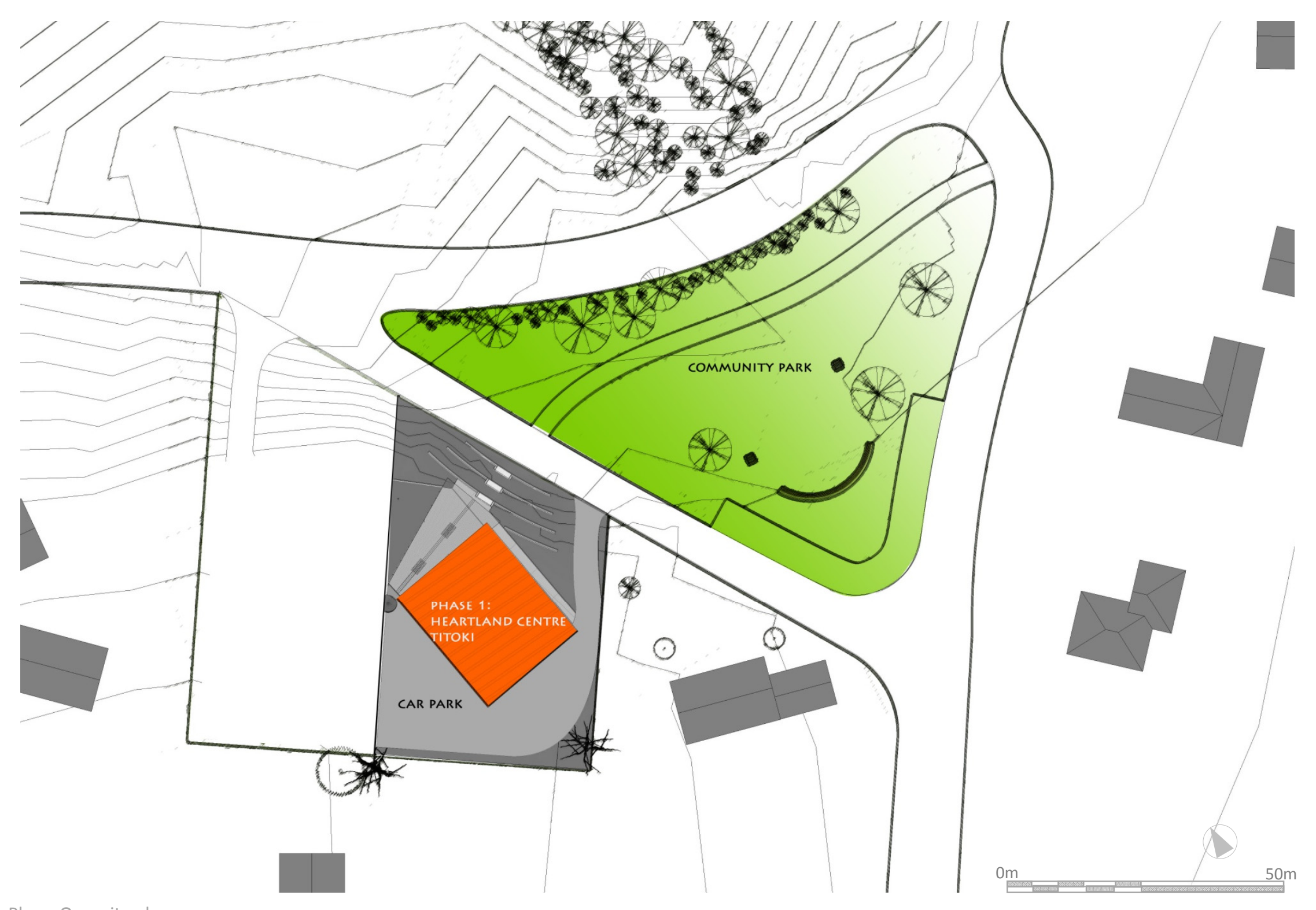

Phase One: site plan 


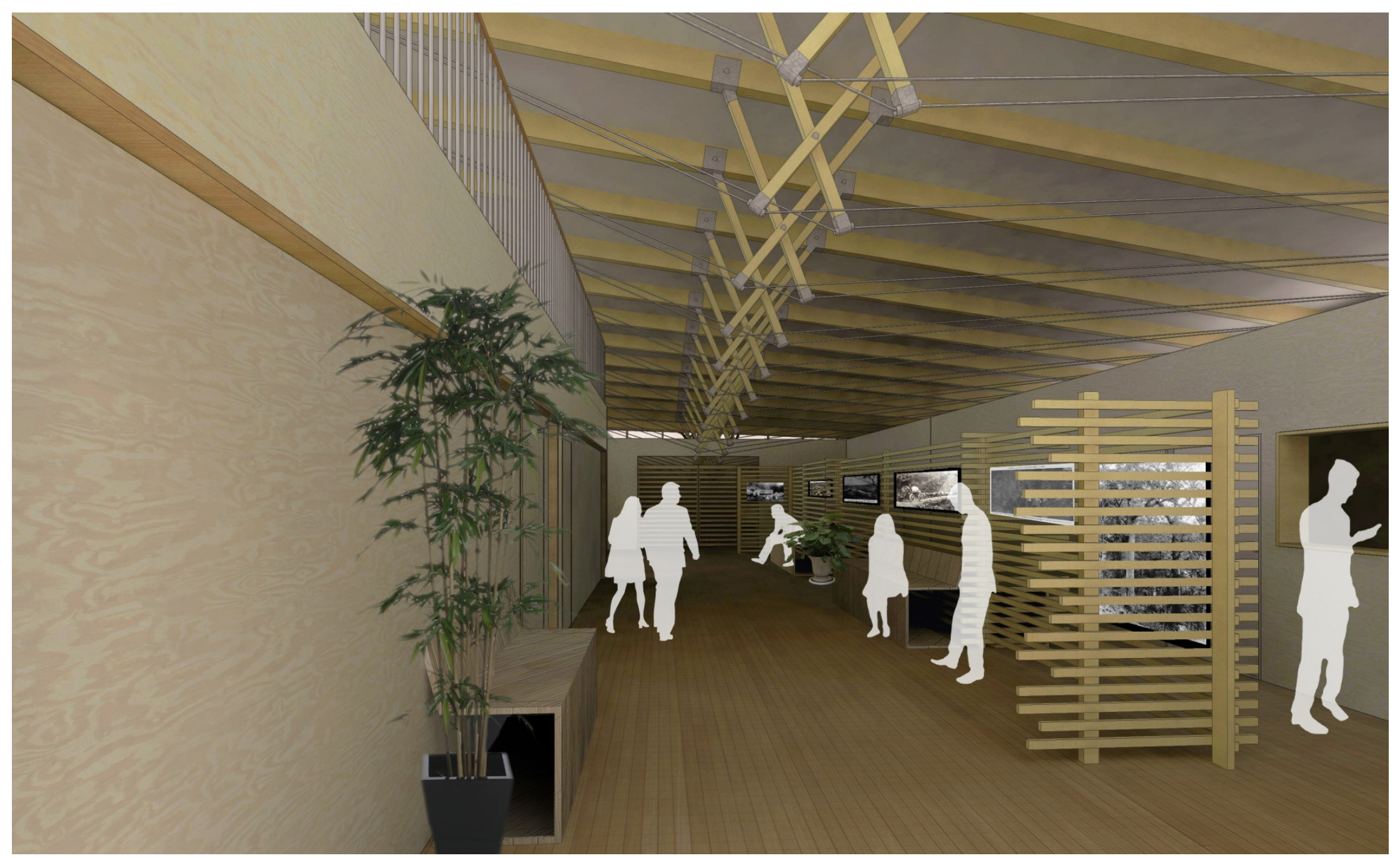

Heartland Centre as professionals offices 


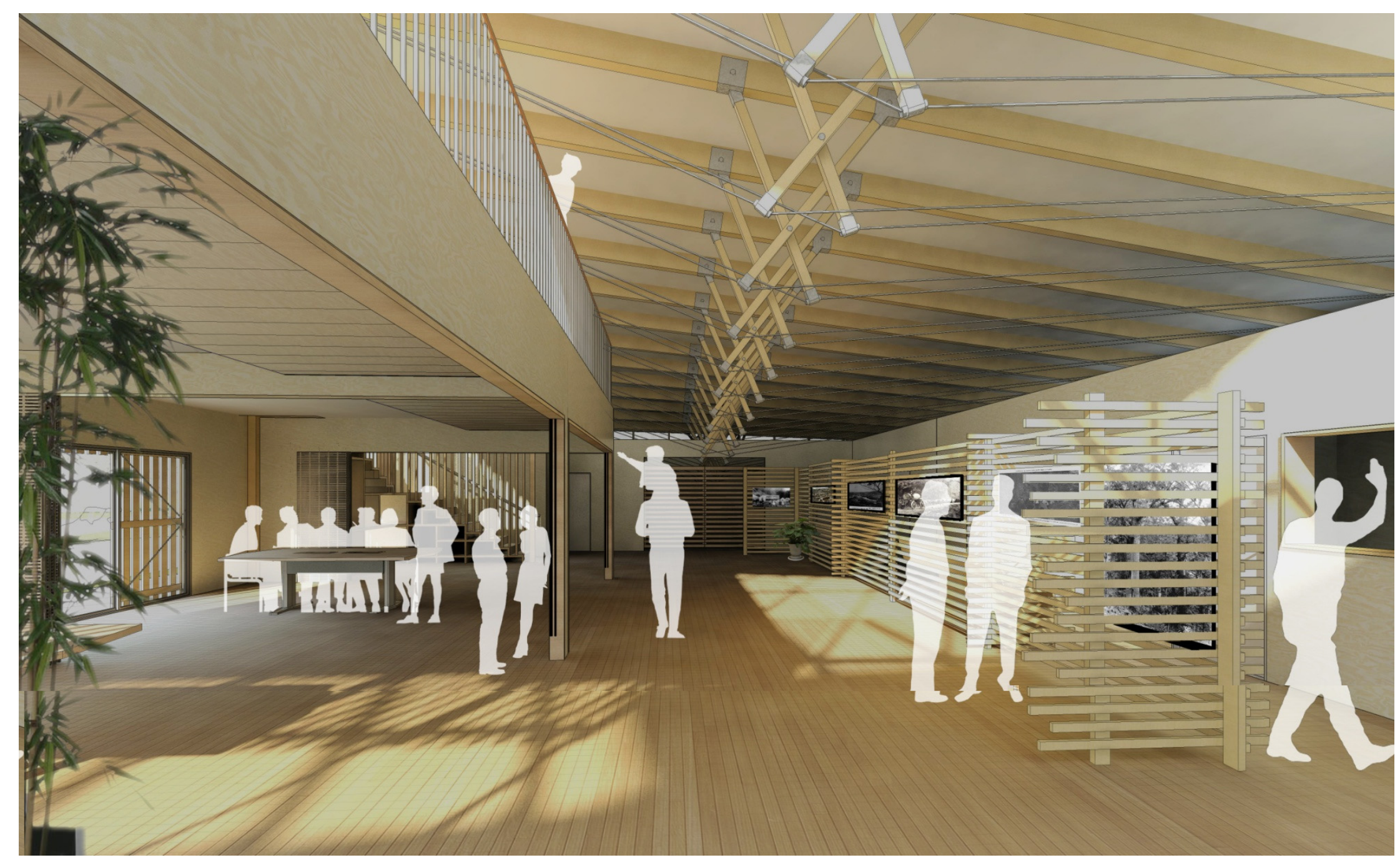

Heartland Centre as opened communal space 


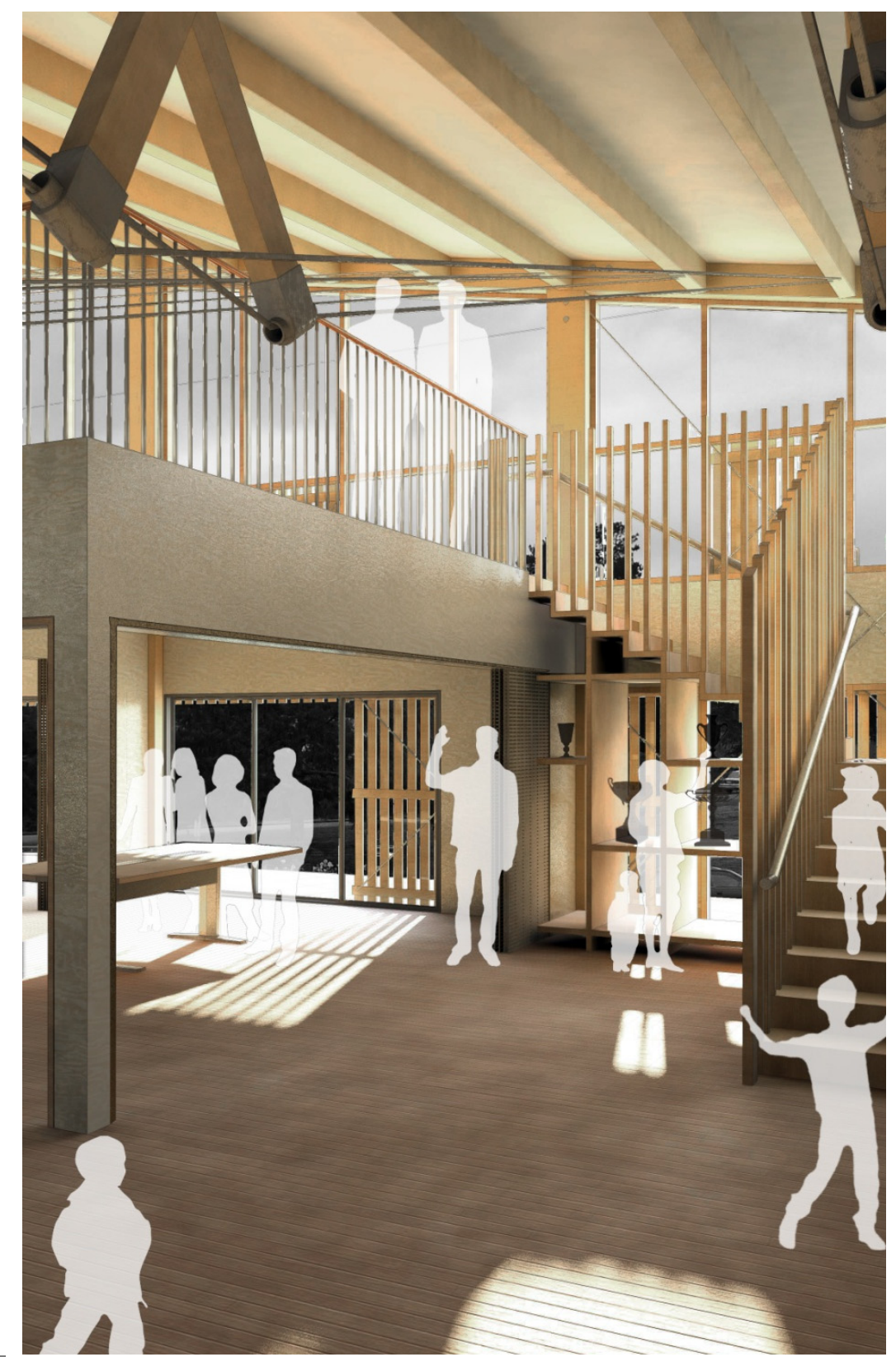




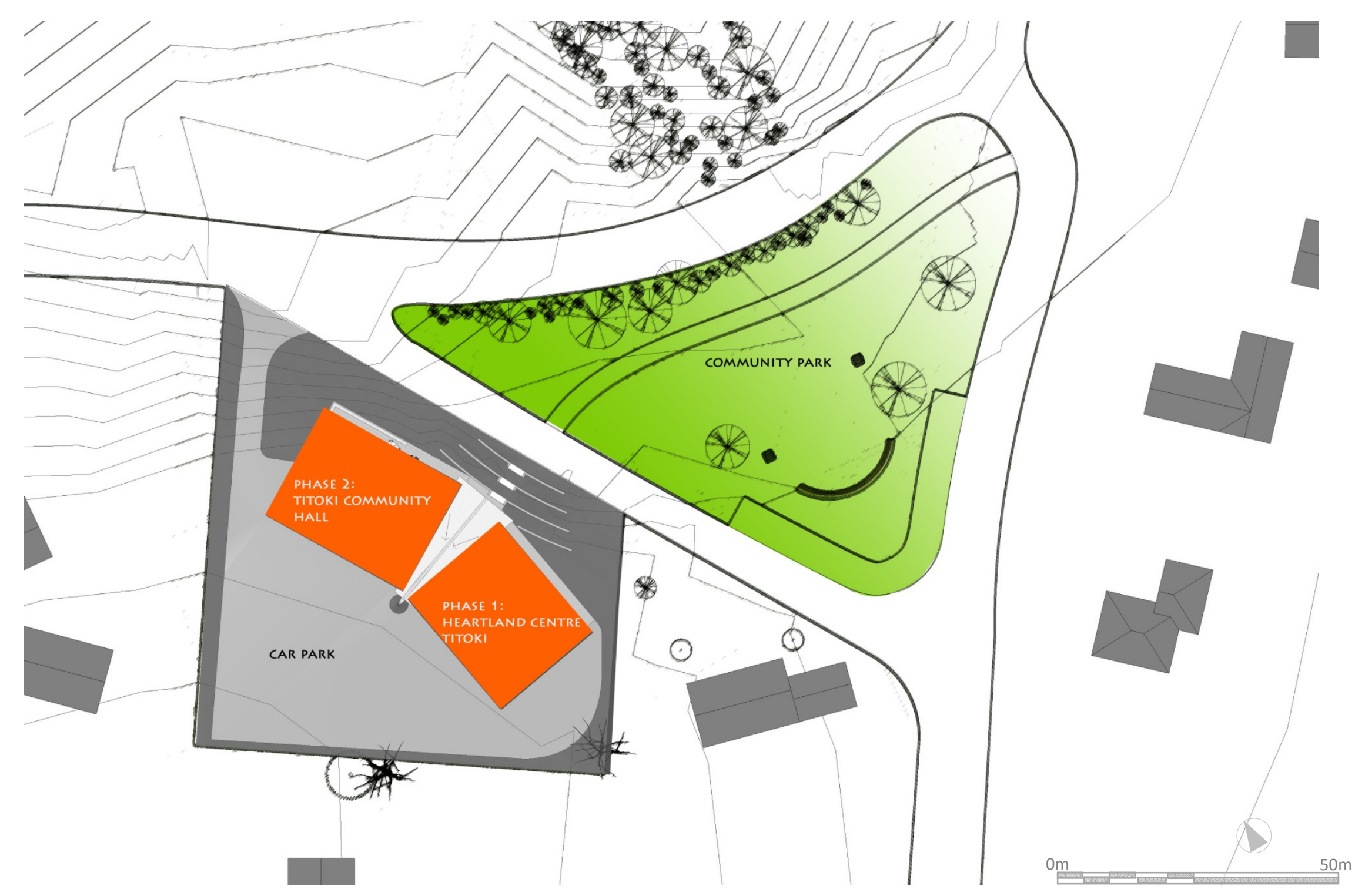

Phase Two: site plan 


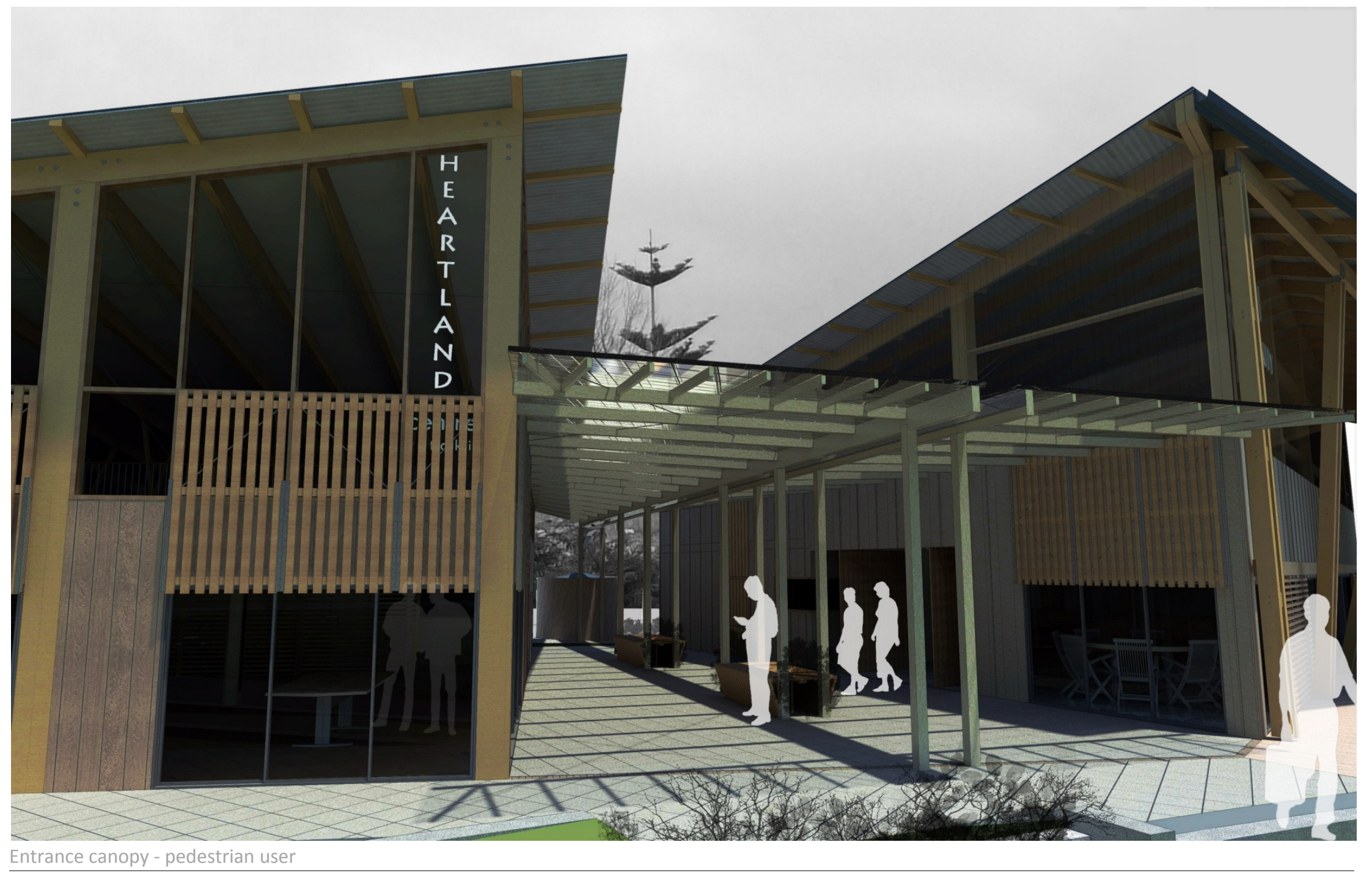




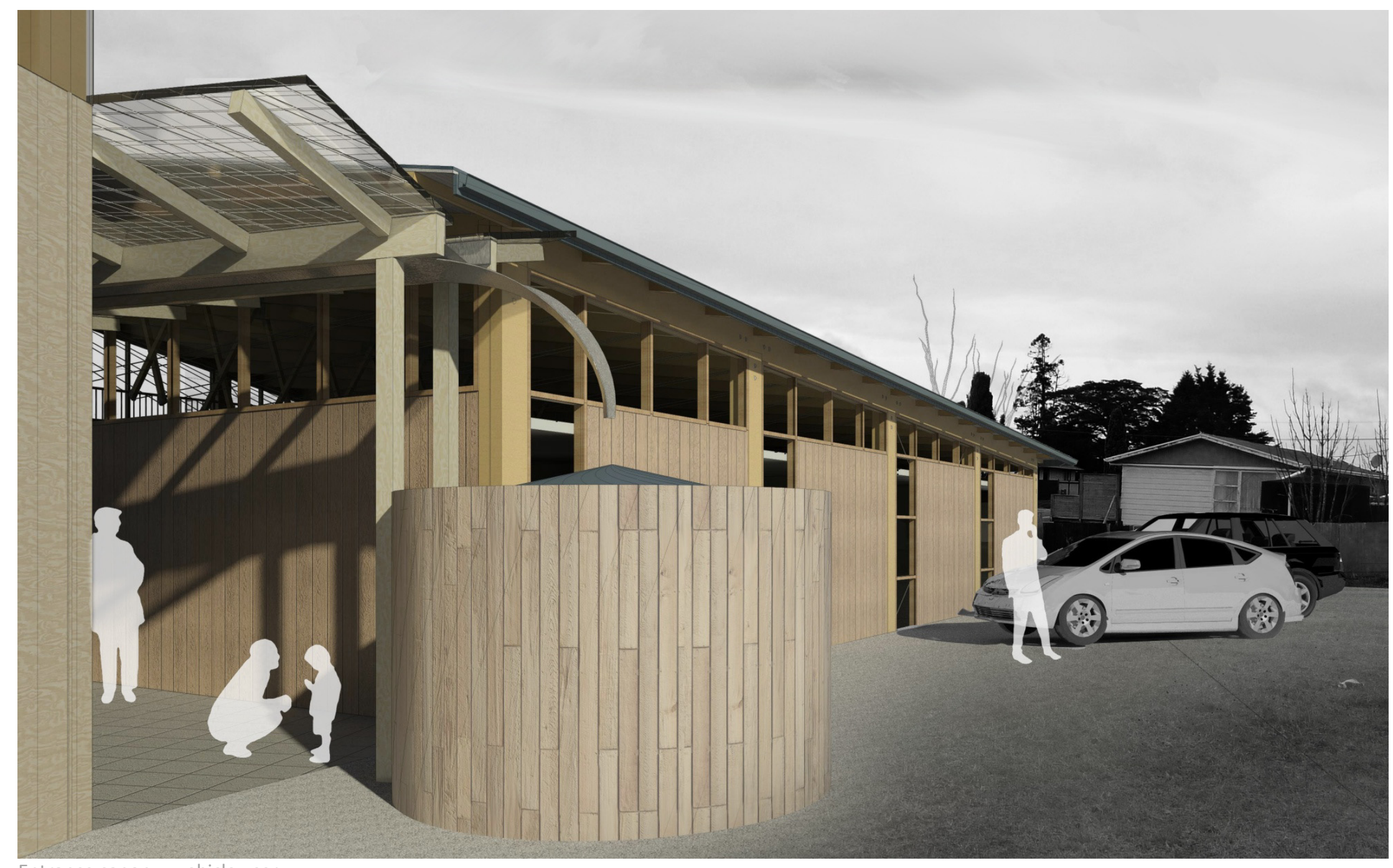




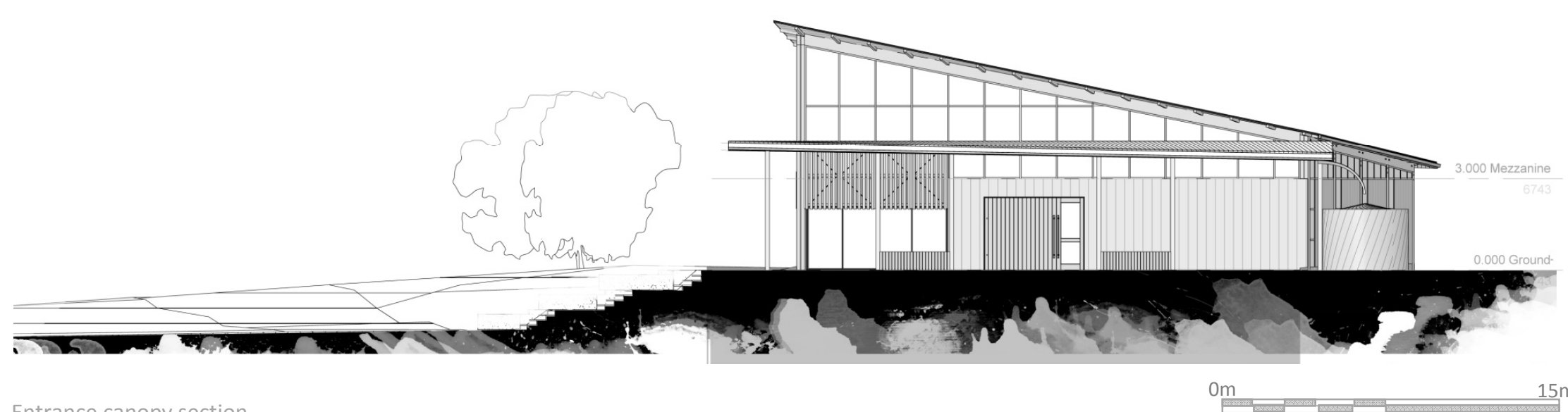

Entrance canopy section 

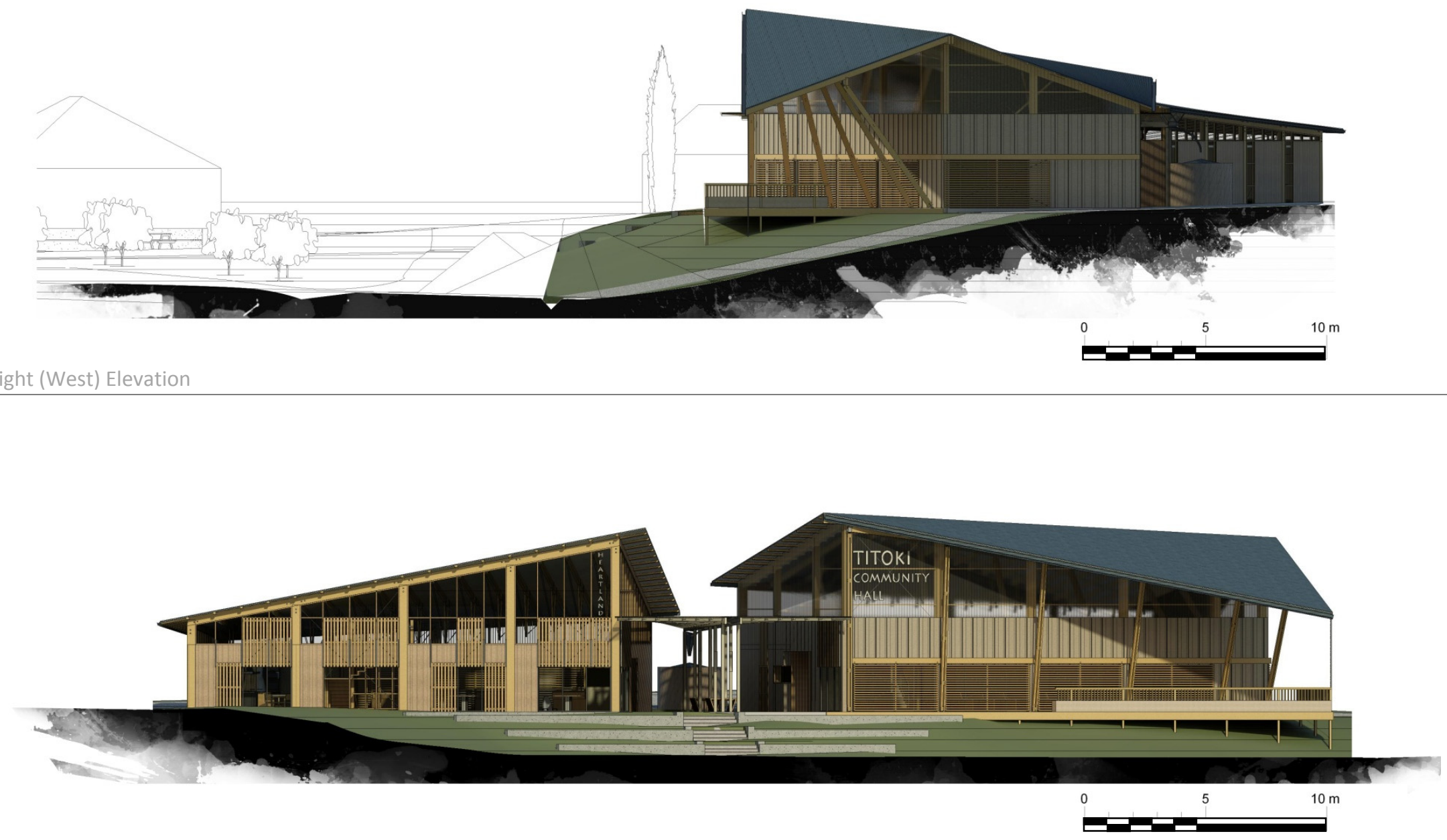


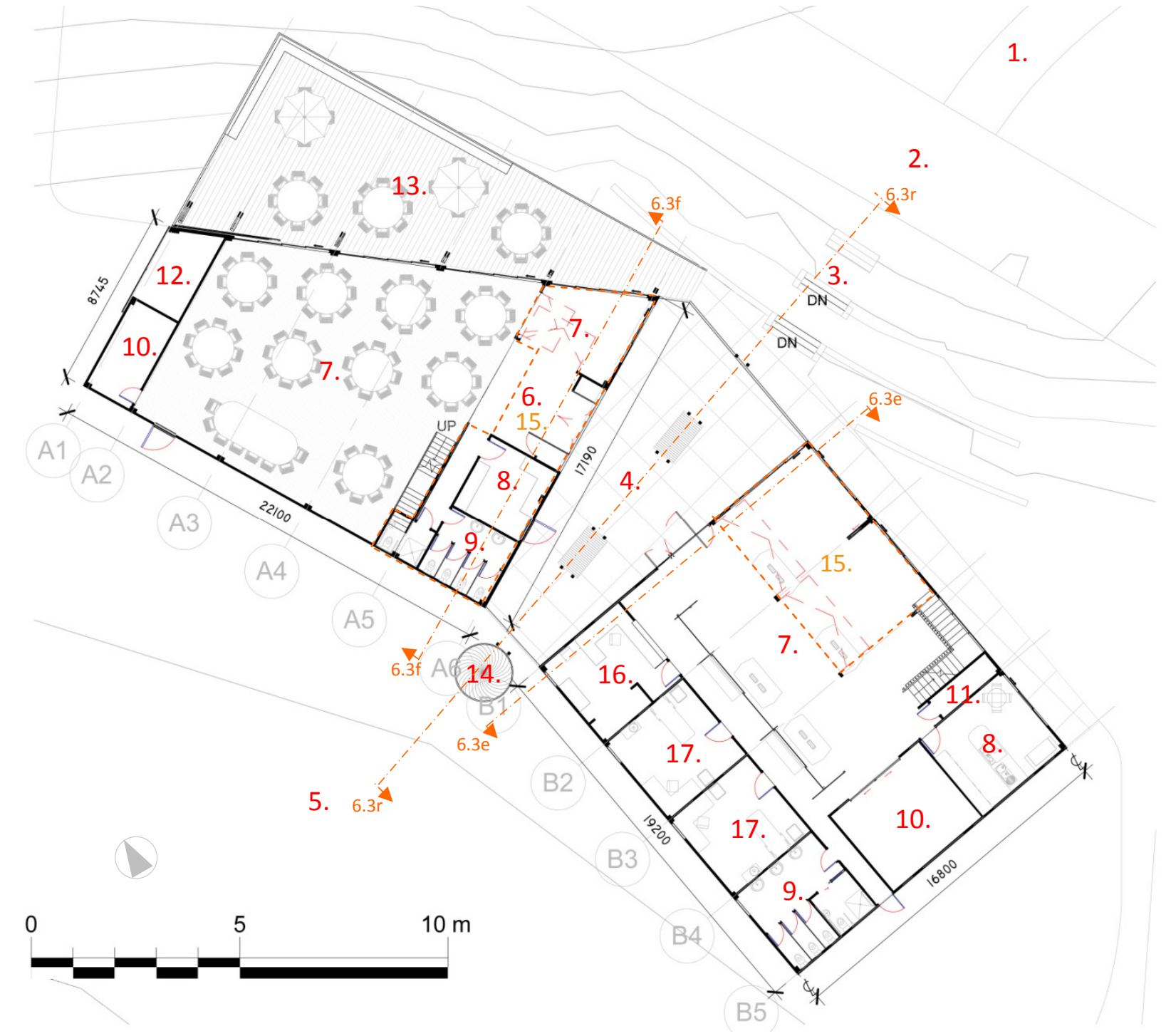

Key:

1. Park

2. Road

3. Pedestrian Entrance

4. Entrance canopy

5. Car park

6. Entrance Foyer

7. Communal Space

8. Kitchen

9. Toilets

10. Storage

11. Cleaning

12. Plant room

13. Outdoor Space

14. Water tank

15. Mezzanine -..--

16. Reception

17. Medical Office

18. Conference Office

19. Waiting Room 


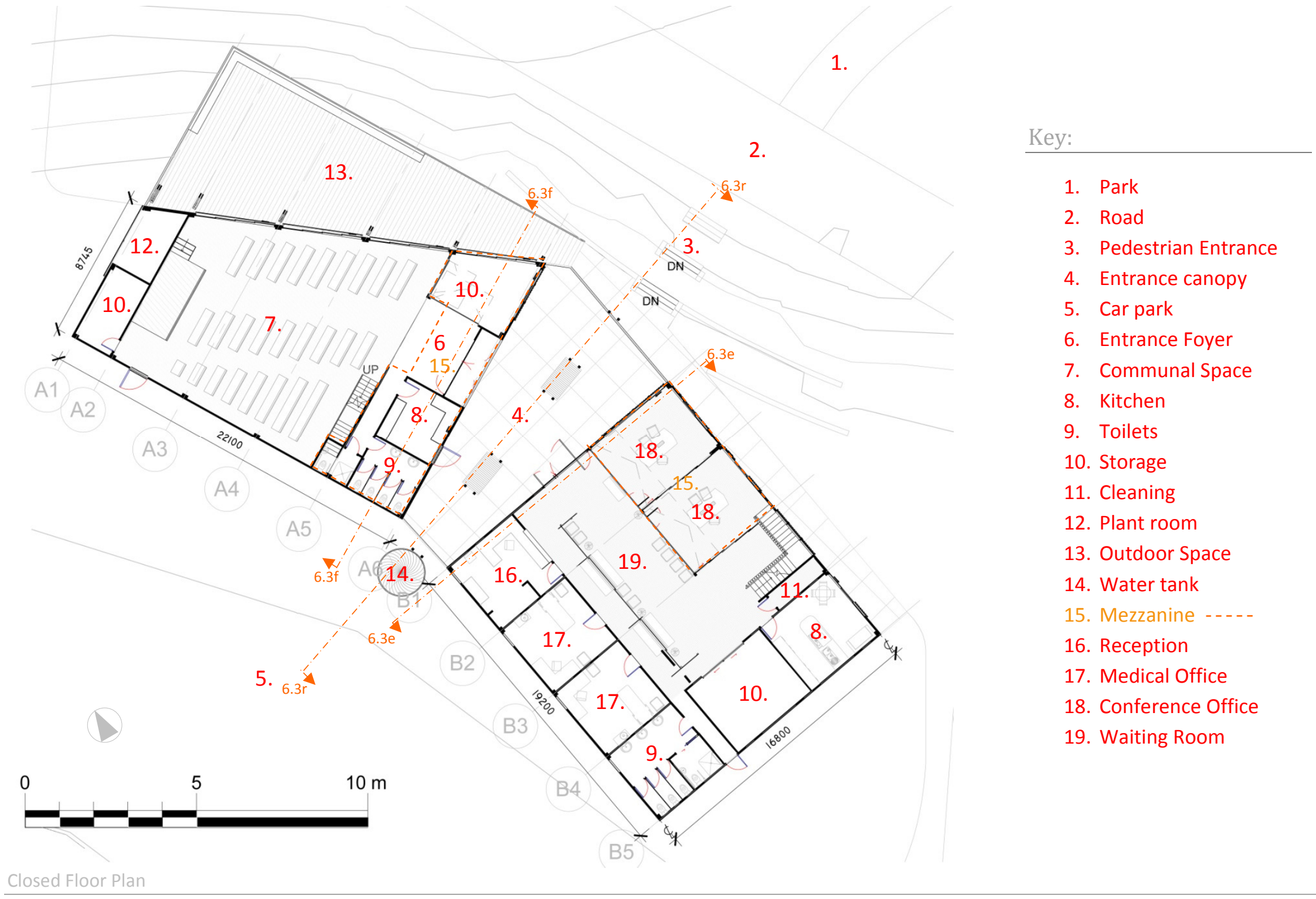




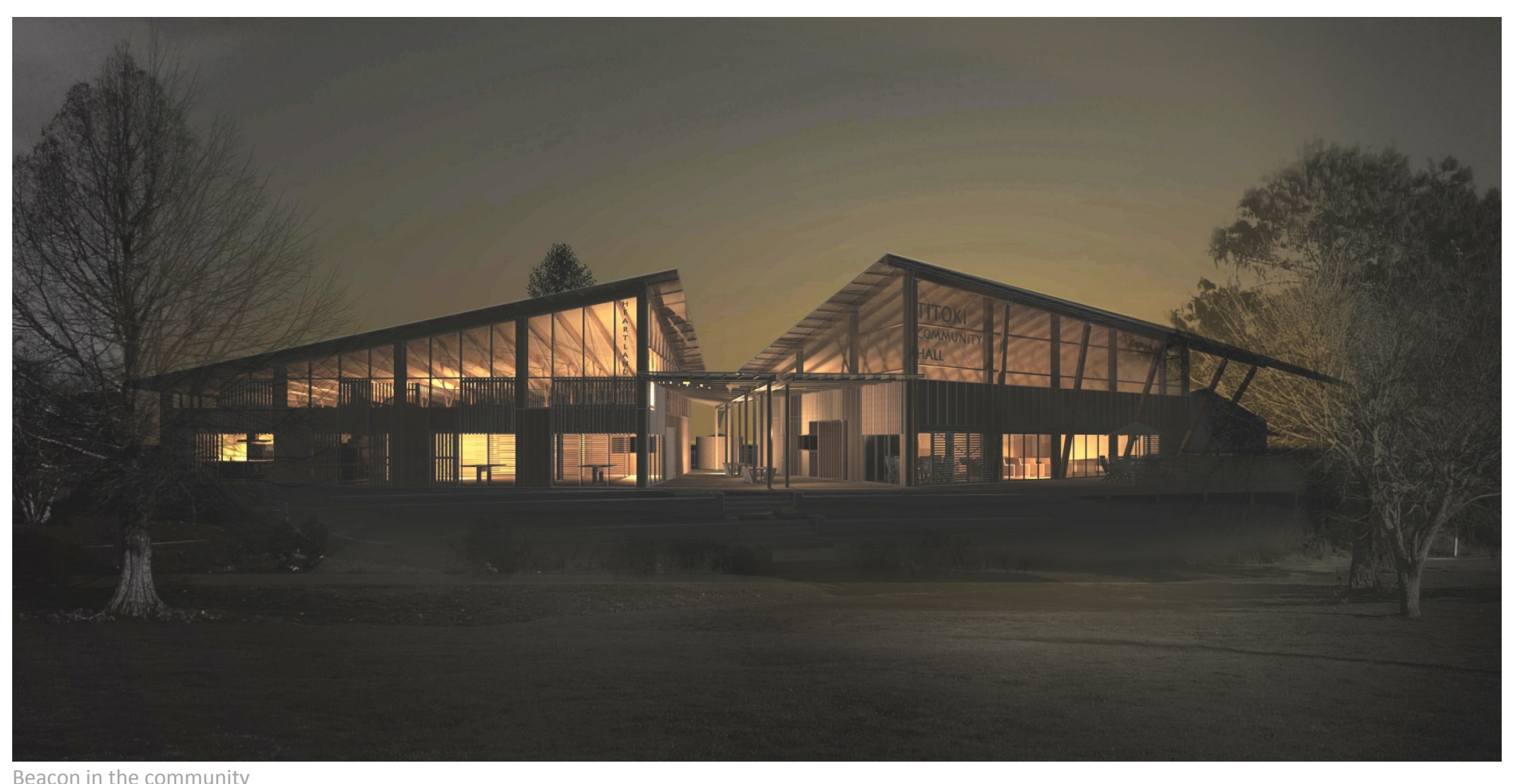

Beacon in the community 


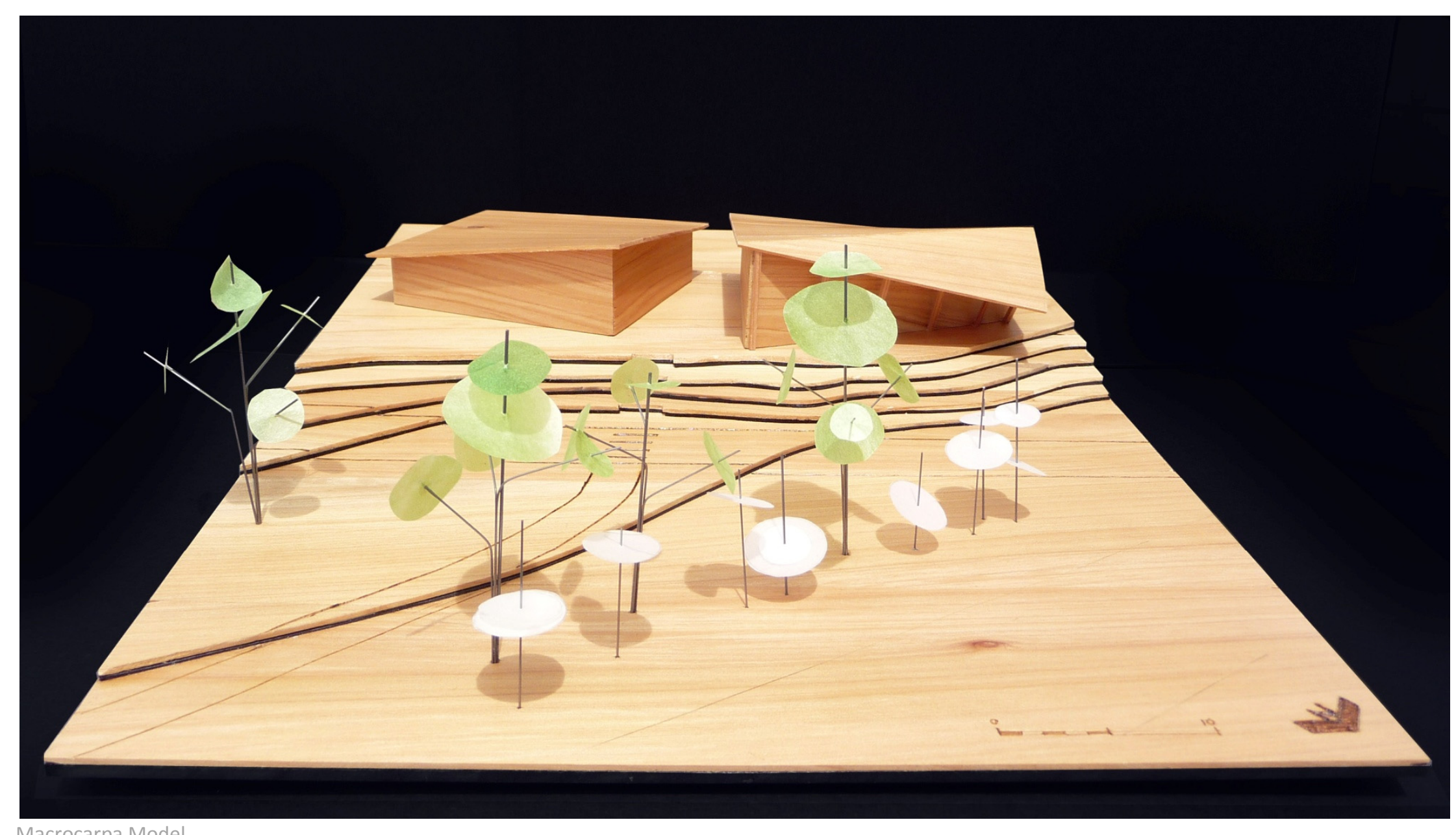

Macrocarpa Model 


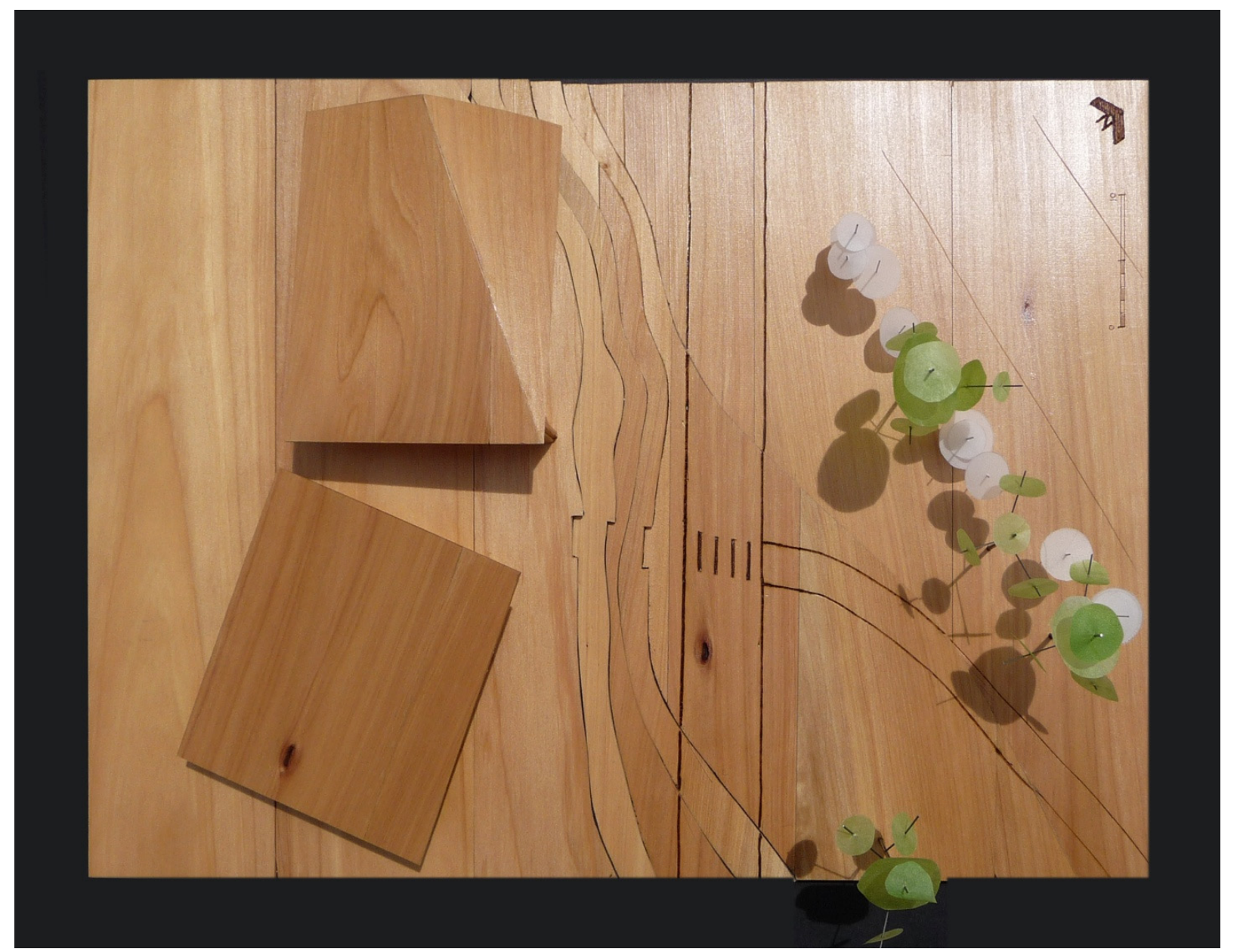

Model site plan 


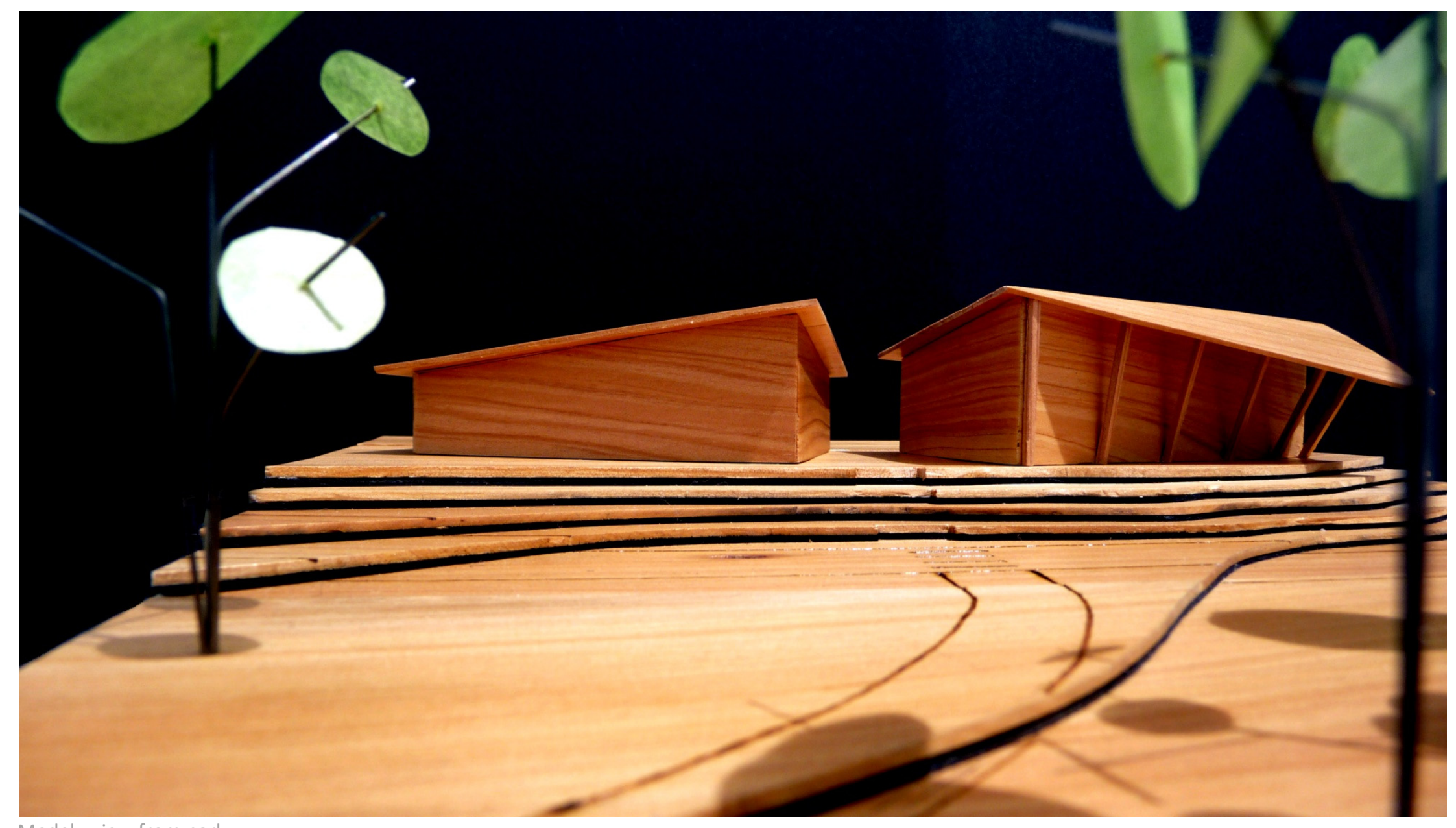

Model - view from park 


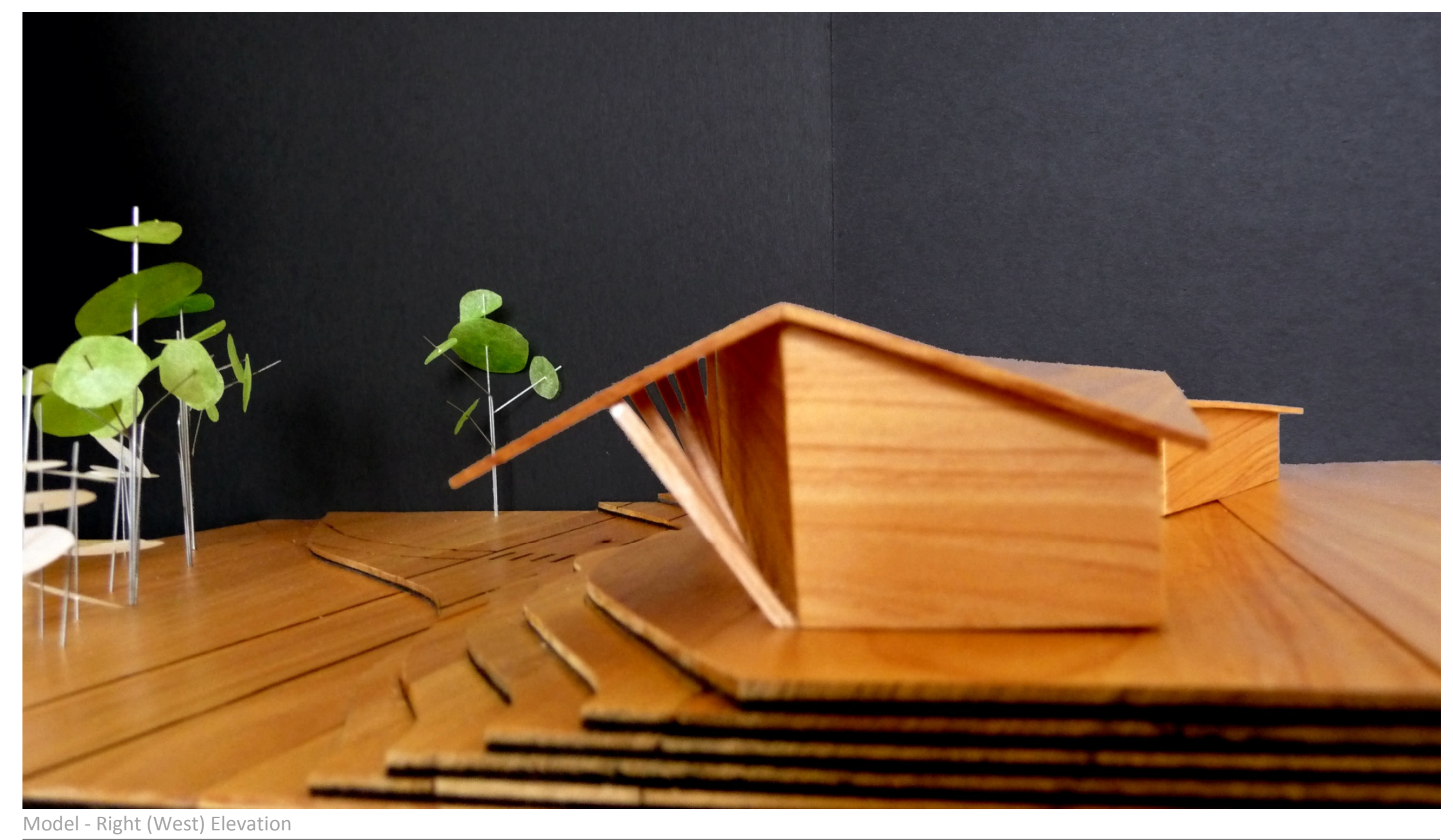




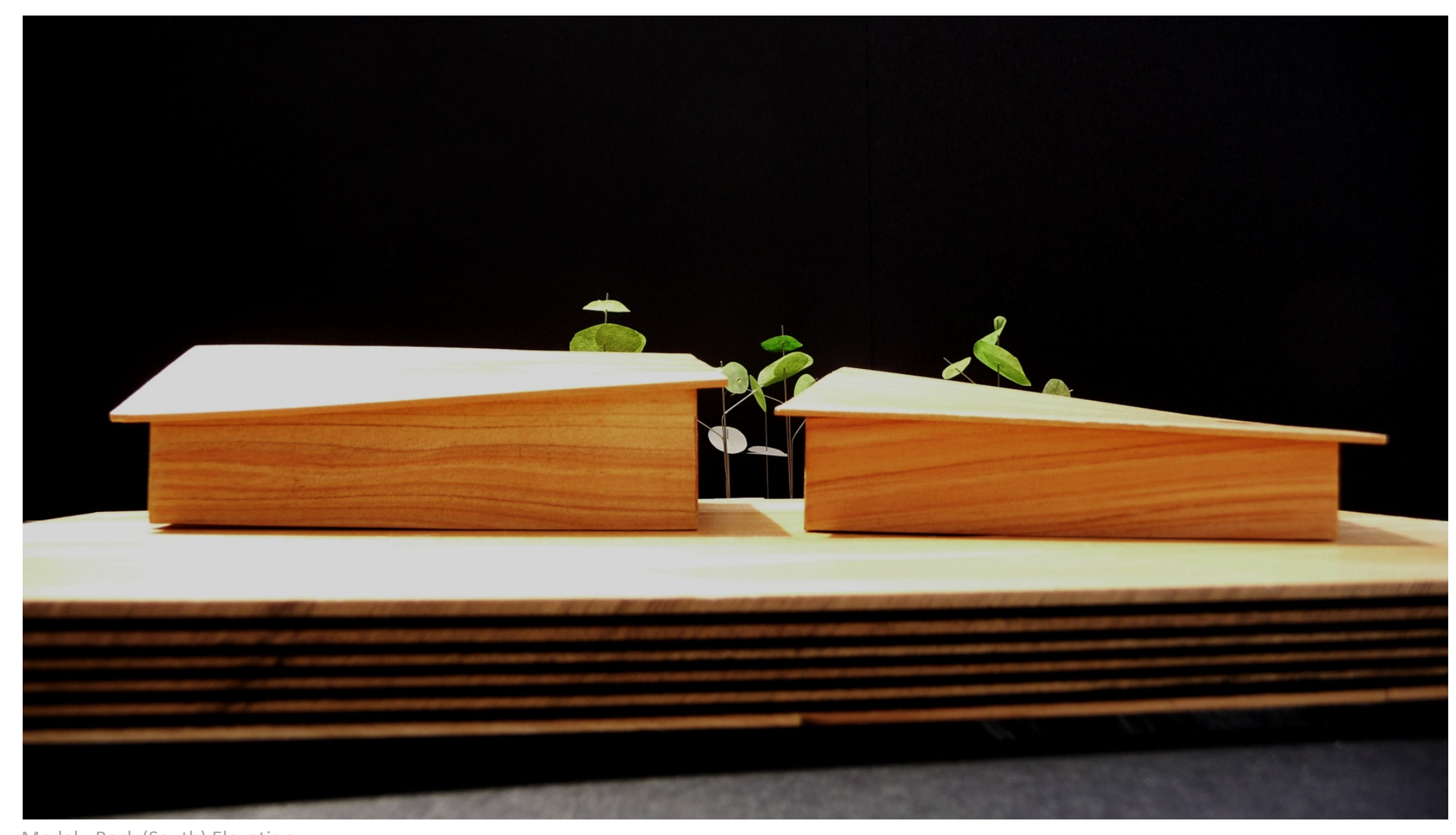

Model - Back (South) Elevation 
9.0 Reference List: | 


\section{References}

Barton, H., Grant, M., \& Guise, R. (2003). Shaping Neighbourhoods: A Guide for Health, Sustainability and Vitality. London: Spon Press.

Bennett, A. (2010, 27 July). Overseas investment rebiew delayed again. New Zealand Herald. from

http://www.nzherald.co.nz/business/news/article.cfm?c id=3\&objectid=10661570.

Bohl, C. C. (2002). Place Making: Developing Town Centers, Main Streets, and Urban Villages. Washington D.C.: ULI - the Urban Land Institute.

Burns, B. R., \& Leathwick, J. R. (1996). Vegetation-environment relationships at Waipoua Forest, Northland, New Zealand. New Zealand Journal of Botany, 34, 79-92.

Callister, P., \& Didham, R. (2010). Workforce composition -Workforce by sector. Te Ara - the Encyclopedia of New Zealand. Retrieved from http://www.teara.govt.nz/en/workforce-composition/1

Casswell, S. (2001). Community Capacity Building and Social Policy - What can be achieved? Social Policy Journal of New Zealand(17), 22-35.

Centennial Committee, \& McCardle, L. (2007). Mangakahia 1907-2007. Whangarei: Centennial Committee.

Chamberlin, B. (1996). Farming and Subsidies: Debunking the Myths. Pukekohe, New Zealand: Euroa Farms Ltd (Publishing Division).

Cheong, P. H., Edwards, R., Goulbourne, H., \& Solomos, J. (2007). Immigration, social cohesion and social capital: A critical review. Critical Social Policy, 27(1), 24-49.

Dean, A. O., \& Hursley, T. (2005). Proceed and Be Bold: Rural Studio After Samuel Mockbee. New York: Princton Architectural Press.

Department of Building and Housing (2010). Fact Sheet - Building Act review results and next steps. Retrieved September 2010. from http://www.dbh.govt.nz/UserFiles/File/Building/Building\%20law\%20and\%20compliance/fact-sheet-BAR-results-next-steps.pdf. 
Department of Internal Affairs (2009). Local Government Act 2002 Retrieved 29 June, 2010, from

http://www.localcouncils.govt.nz/lgip.nsf/wpg URL/About-Local-Government-Local-Government-Legislation-Local-Government-Act2002?OpenDocument

Dickison, M. (2010, 23 August). Campaign demands halt to farm sales. New Zealand Herald. from

http://www.nzherald.co.nz/nz/news/article.cfm?c id=1\&objectid=10668183.

Easton, B. (2010). The New Zealand Economy 27 April 2010. Retrieved 23 June, 2010, from http://www.eastonbh.ac.nz/?p=1117

Ehrenfeld, D. (2009). Becoming Good Ancestors: how we balance nature, community, and technology. New York: Oxford University Press.

Falk, I., \& Kilpatrick, S. (2000). What is social capital? A study of interaction in a rural community. Sociologia Ruralis, 40(1), 87-110.

Federated Farmers of New Zealand (2010). Farming Facts Retrieved 23 June 2010, from http://www.fedfarm.org.nz/n1051,4.html

Field, J. (2008). Social Capital (Second ed.). Abingdon, Oxon: Routledge.

Filion, P. (2009). The mixed success of nodes as a smart growth planning policy. Environment and Planning B: Planning and Design, 36(3), 505-521.

Fraser, E. (2010). Photographic documentation. In Sample Communities (Ed.). Whangarei.

GeoEye, Whangarei District Council, \& Digital Globe (Cartographer). (2010). Google Earth.

Google Earth (Cartographer). (2010). Base Map.

Gusheh, M., Heneghan, T., Lassen, C., \& Seyama, S. (2008). Glenn Murcutt: Thinking Drawing / Working Drawing (2nd ed.). Tokyo: Nobuyuki Endo.

Gusheh, M., Heneghan, T., Lassen, C., \& Seyama, S. (2009). The Architecture of Glenn Murcutt (2nd ed.). Tokyo: Nobuyuki Endo.

Halpern, D. (2007). Social Capital. Canmbridge: Polity Press.

Hogg, R., \& Carrington, K. (2006). Policing the Rural Crisis. Annandale, N.S.W.: Federation Press. 
Jack, F. (2010). Living Halls Retrieved September, 2010, from http://fionajack.net/projects/living-halls/

Jones, M. A. (2003). Can Technology Transform? Experimenting with Wired Communities. In B. E. Kolko (Ed.), Virtual Publics: Policy and Community in an Electronic Age. New York: Columbia University Press.

Joseph, A. E. A. E. (1999). Toward an Understanding of the Interrelated Dynamics of Change in Agriculture and Rural Communities. Hamilton, N.Z.:

Population Studies Centre, University of Waikato.

Kelland, C. (1993). Making a Difference in Rural New Zealand, Alternative Ways of Responding to Rural Communities: An Examination of Responses to Initiatives in Rural Areas and an Alternative Framework for Appraising Community Proposals. Geraldine, N.Z.: C. Kelland.

Key, J. (2010). Key Notes: Supporting our rural communities Retrieved 08 September, 2010, from http://www.johnkey.co.nz/archives/967-KeyNotes-Supporting-our-rural-communities.html

Kolko, B. E. (Ed.). (2003). Virtual Publics: Policy and Community in an Electronic Age. New York: Columbia University Press.

Livestock Improvement Corporation (2008). New Zealand Dairy Statistics 2007-2008: Livestock Improvement Corporation

DairyNZ.

MacKay-Lyons, B. (1995). Seven Stories from a Village Architect. Design Quarterly, Summer(165), 1-31. Retrieved from http://www.jstor.org/stable/4091342

Ministry for the Environment (2010). The New Zealand Emissions Trading Scheme - information for farmers and landowners Retrieved 30 June, 2010, from http://www.climatechange.govt.nz/emissions-trading-scheme/about/what-it-means-for-me/brochure-farmers/index.html 
Ministry of Agriculture and Fisheries (1993). Sustainable Agriculture - MAF POLICY POSITION PAPER 1. In Ministry of Agriculture and Fisheries (Eds.) Available from http://www.maf.govt.nz/mafnet/rural-nz/sustainable-resource-use/land-management/sustainable-agriculture-positionpaper/suspol.htm\#E11E1

Ministry of Agriculture and Fisheries (2002). 4.0 Financial Profile of the Small Scale Dairy Farm. The Viability of Small Dairy Farms Retrieved 23 June, 2010, from http://www.maf.govt.nz/mafnet/rural-nz/profitability-and-economics/performance/viability-of-small-dairy-farms/dairy-05.htm Mulet-Marquis, S., \& Fairweather, J. R. (2008). New Zealand Farm Structure Change and Intensification (No. 301): Lincoln University, Canterbury. National Institute of Water and Atomspheric Research (2008). Climate Summaries Retrieved 9 August, 2010, from http://www.niwa.co.nz/education-and-training/schools/resources/climate/summary

Neal, P. (Ed.). (2003). Urban Villages and the Making of Communities. London: Spon Press.

Northland District Health Board (2010). Living in Northland Retrieved 9 August, 2010, from http://www.northlanddhb.org.nz/careers/living-inNorthland/climate/

Putnam, R. (2001). Bowling Alone: the collapse and revival of American community. London: Smith \& Schuster.

Quantrill, M. (2005). Plain Modern: The Architecture of Brian MacKay-Lyons. New York: Princeton Architectural Press.

Rahman, M. H., \& Yamao, M. (2007). Community Based Organic Farming and Social Capital in Different Network Structures: Studies in Two Farming Communities in Bangladesh. American Journal of Agricultural and Biological Science, 2(2), 62-68.

Rhodes, T., Willis, B. H., Smith, W., \& McCann, J. (2003). Farm Adjustment and Restrucuring in the North Island Hill Country.

Rose, J. M. (1994). The Role of the School in Rural Communities in New Zealand. Wellington [N.Z.]: Ministry of Agriculture and Fisheries,. 
Salmond, C., Crampton, P., \& Atkinson, J. (2007). NZDep2006 Index of Deprivation. Retrieved from

http://www.uow.otago.ac.nz/academic/dph/research/NZDep/NZDep2006\%20research\%20report\%2004\%20September\%202007.pdf

Save the Farms (2010). Save the Farms - Home page Retrieved 27 August, 2010, from http://www.savethefarms.org.nz/default.aspx

Shaffer, C. R., \& Anundsen, K. (2005). Creating Community Anywhere: Finding Support and Connection in a Fragmented World (Second ed.). Dillion Beach,CA: CCC Press.

Smith-Lovin, L. (2007). The Strength of Weak Identities: Social Structural Sources of Self, Situation and Emotional Experience. Social Psychology Quarterly, 70(2), 106-124.

Spellerberg, A. (2001). Framework for the Measurement of Social Capital in New Zealand (No. 14). Wellington: Statistics New Zealand.

Statistics New Zealand (1999). New Zealand - A Regional Profile: NORTHLAND. Wellington: Statistics New Zealand.

Statistics New Zealand (2004). New Zealand: Urban/Rural Profile. Rural Areas with Low Urban Influence. Retrieved from http://www.stats.govt.nz/Publications/BusinessPerformanceEnergyAndAgriculture/urban-rural-profile/rural-areas-low-urbaninfluence.aspx

Statistics New Zealand (2005a). Defining Urban and Rural New Zealand Retrieved 21 May, 2010, from http://www.stats.govt.nz/publications/businessperformanceenergyandagriculture/urban-rural-profile/defining-urban-rural-nz.aspx

Statistics New Zealand (2005b). New Zealand: Urban/Rural Profile. Rural Areas with Low Urban Influence. Retrieved from http://www.stats.govt.nz/Publications/BusinessPerformanceEnergyAndAgriculture/urban-rural-profile/rural-areas-low-urbaninfluence.aspx

Statistics New Zealand (2006). 2006 Census Data Retrieved 28 June, 2010, from http://www.stats.govt.nz/Census/2006CensusHomePage.aspx 
Statistics New Zealand (2009). Review of crime and criminal justice statstics report 2009

The Treasury (2010). New Zealand Economic and Financial Overview 2010 Retrieved 23 June, 2010, from

\section{http://www.treasury.govt.nz/economy/overview/2010/04.htm}

Trancik, R. (1986). Finding Lost Space: Theories of Urban Design. New York: Van Nostrand Reinhold Company.

UMR Research Limited (2008). Beliefs and Values Research: Urban and rural perspectives of the primary sector. Retrieved March 2010. from

http://www.maf.govt.nz/mafnet/rural-nz/people-and-their-issues/social-research-and-welfare/beliefs-and-values/beliefs-and-values-

research-report-08.pdf.

Ville, S. (2000). The Rural Entreprenuers: A History of the Stock and Station Agent Industry in Australia and New Zealand. Cambridge: The Press Synicate of the University of Cambridge.

Walker, R. B., \& Hiller, J. E. (2007). Places and Health: A qualitative study to explore how older women living alone perceive the social and physical dimensions of their neighbourhoods. Social Science \& Medicine, 65, 1154-1165.

Ward, N., \& Brown, D. L. (2009). Placing the Rural in Regional Development. Regional Studies, 43(10), 1237 - 1244.

Watt, S. E., Lea, M., \& Spears, R. (2002). How Social is Internet Communication? A Reappraisal of Bandwidth and Anonymity Effects. In S. Woolgar (Ed.), Virtual Society? Technology, Cyberbole Reality (pp. 61-77). United Statea: Oxford University Press.

Westrate, E. (Producer). (2007, 02 July 2010) The Village Architect. design. Podcast retrieved from http://www.pbs.org/e2/episodes/302 the village architect excerpt.html.

Whangarei District Council (2007). this place - our places: Whangarei District Council's Community Halls Strategy. Retrieved from http://www.wdc.govt.nz/resources/12135/Community-Halls-Strategy-September-2007.pdf\#search="community halls strategy" 
Whangarei District Council (2010a). District Plan Changes. Plan Change 93: Urban Transition Environment (UTE) Retrieved 30 June, 2010, from http://www.wdc.govt.nz/customerservice/?lc=reader\&m=ts\&i=1741

Whangarei District Council (2010b). Whangarei District Plan. Retrieved 30 June 2010. from

http://www.wdc.govt.nz/customerservice/?lc=reader\&m=ts\&i=1664.

Windels, C. E. (2000). Economic and Social Impacts of Fusarium Head Blight: Changing Farms and Rural Communities in the Northern Great Plains. Phytopathology, 90(1), 17-21

Yellow.co.nz (2010). Yellow Pages Retrieved June, 2010, from http://yellow.co.nz/index.jsp?cid=GGS-YB-

Yellowpagesbrand\&keyword=yellow\%20pages\%20nz\&creative=5246519780\&gclid=CMf6pebWmaUCFQUmbAodLjS2Jw

Yerex, D. (1992). The Farming Fiasco: Why New Zealand, Our Farmers and the World's Poor All Lose Out. Petone, New Zealand: GP Publications Limited. 